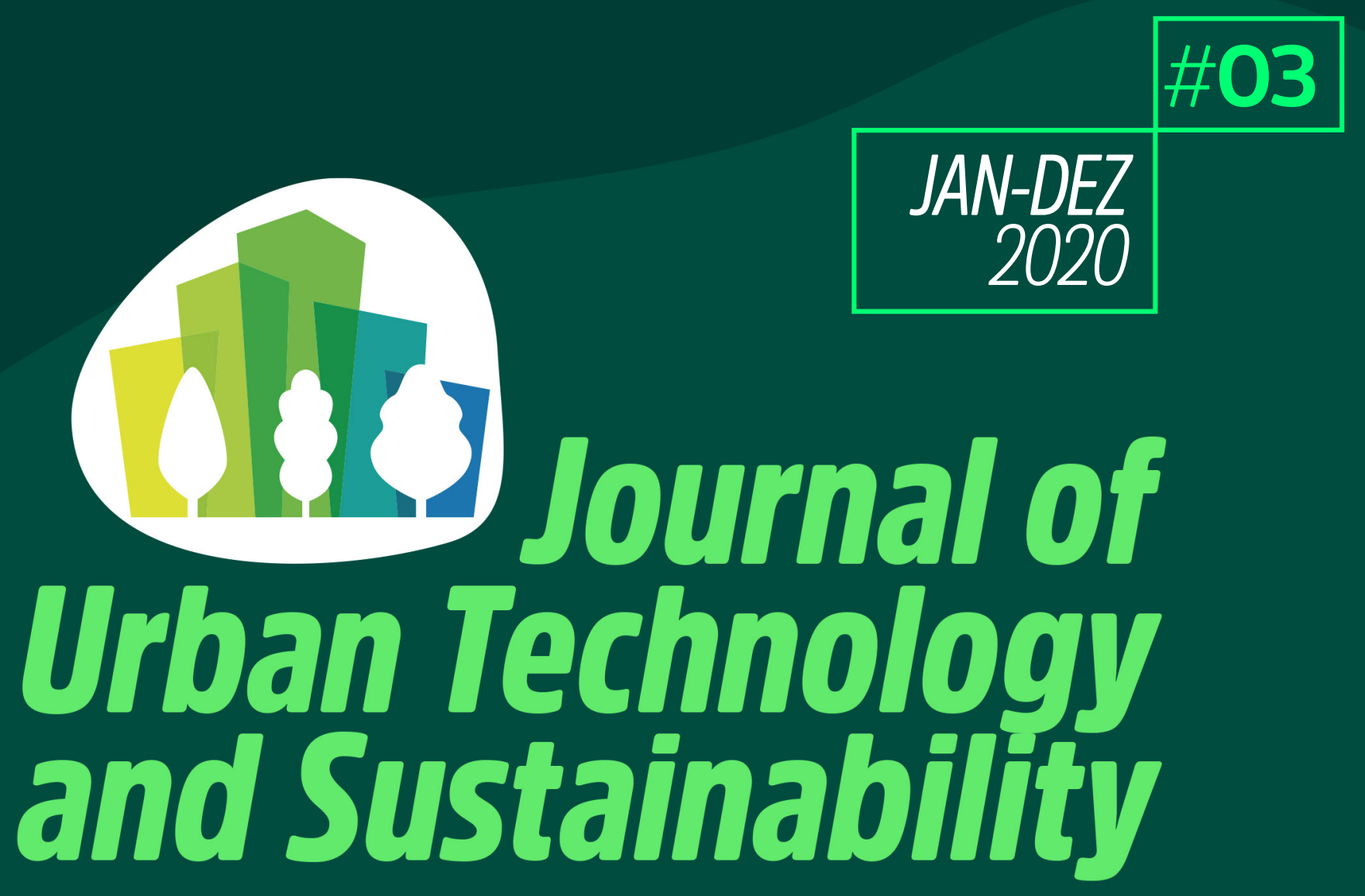

Publicação organizada pelo Programa de Mestrado Profissional Stricto Sensu em Engenharia Civil da Universidade São Judas
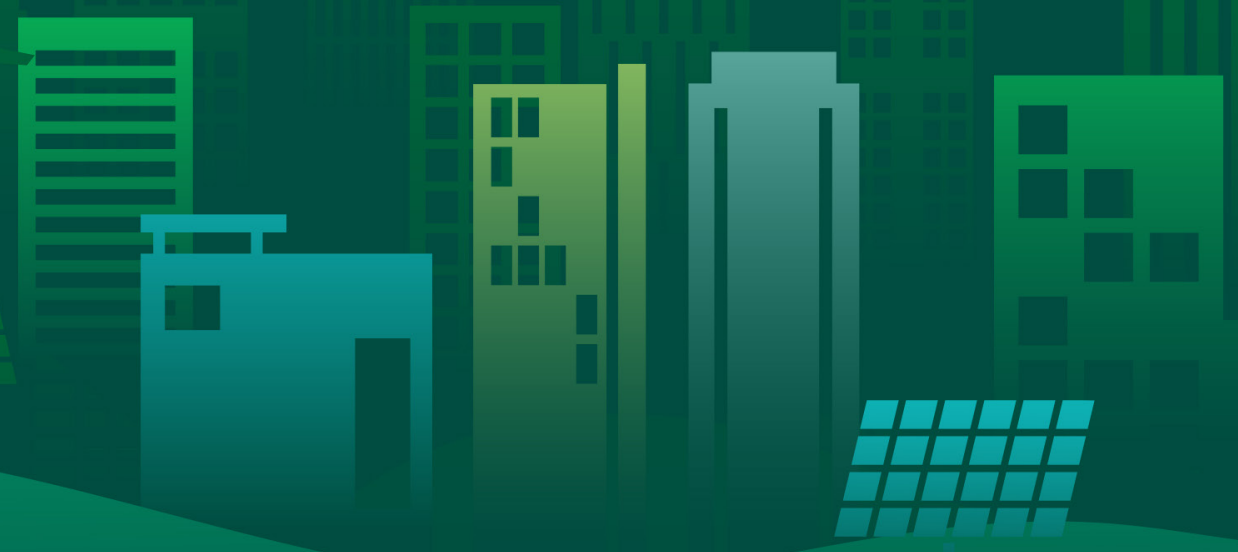

sāojudas'

pesquisa $\delta$ pós-graduação stricto sensu 
Publicação organizada pelo Programa de Mestrado Profissional Stricto Sensu em Engenharia Civil da Universidade São Judas

\section{Volume 03 - Edição 01}

Janeiro - Dezembro de 2020

\section{O Journal of Urban Technology and Sustainability proporciona} um fórum internacional para a disseminação de pesquisas inovadoras e transdisciplinares relacionadas ao planejamento

Urbano e Regional, aos Materiais de Construção Civil, à Tecnologia de Sistemas Construtivos e à Sustentabilidade do Ambiente Construído. Fazem parte do escopo da revista os artigos científicos, relatos técnicos, estudos de caso e artigos de revisão que contribuam para desenvolver e aprimorar o conhecimento na área. A revista fornece recursos de grande importância para integrar e unificar a colaboração entre pesquisadores, profissionais e estudantes da área.

\section{Editor chefe}

Prof. Dr. Renan Pícolo Salvador

\section{Editores Adjuntos}

Profa. Dra. Cláudia Terezinha Kniess

Prof. Dr. Dimas Alan Strauss Rambo

Assistente Editorial

Altieres de Oliveira Silva 


\section{SUMÁRIO}

As cidades e o aquecimento global: desafios para o planejamento urbano, as engenharias e as ciências sociais e básicas

Contribuição para o desenvolvimento de uma metodologia de dosagem para concreto permeável baseada no desempenho

Teste acelerado de argamassas e a combinação de adições minerais ativas com agregado potencialmente reativo

Autoconstrução e autogestão habitacional no Brasil: um estudo comparativo em dois períodos: 1975-1986 e 2004-2018

A seca e seus desdobramentos: reflexões a partir da realidade da Microrregião de Pau dos Ferros

A produção habitacional do programa MCMV no município de São Paulo: critérios de localização adotados pelos produtores e impactos na estrutura urbana e na qualidade de vida dos moradores

Discurso sustentável e a prática de remanejamento: Estudo de caso em intervenção habitacional do Programa de Aceleração do Crescimento em Belém (PA) 
Publicação organizada pelo Programa de

Mestrado Profissional Stricto Sensu em

Engenharia Civil da Universidade São Judas

Volume 03 - Edição 01

Janeiro - Dezembro de 2020

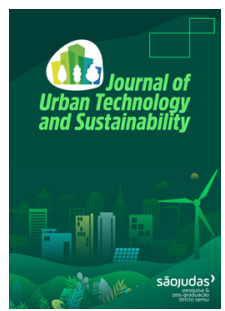

\section{As cidades e o aquecimento global: desafios para o planejamento urbano, as engenharias e as ciências sociais e básicas}

Renato L. S. Anellia,*

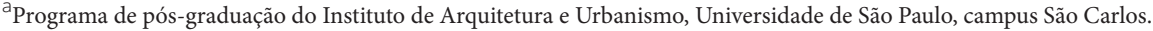

\section{Informações}

Recebido 7 Fevereiro 2020

Manuscrito revisado recebido 8 Abril 2020

Aceito 12 Abril 2020

Palavras-chave

Aquecimento global

Planejamento urbano

Mudanças climáticas

Sustentabilidade

\section{Resumo}

Este artigo tem como objetivo apresentar uma abordagem transdisciplinar para a relação entre as mudanças climáticas e as cidades. Parte do reconhecimento de que a atual forma da urbanização das grandes regiões metropolitanas é forte agente promotor do aquecimento global, ao mesmo tempo que constitui lócus da manifestação nociva dos efeitos dessas mudanças. A alteração dos regimes de chuva, com maior frequência e intensidade, da distribuição das precipitações e do fenômeno das ilhas de calor afetam em especial as áreas de assentamentos mais precários, onde a elevada vulnerabilidade social expõe gigantescos contingentes de pessoas a riscos constantes de inundação, deslizamentos, falta de água potável e saneamento básico, e doenças geradas pelo calor excessivo. A busca por sustentabilidade ambiental envolve essa dimensão social, exigindo das ciências e das técnicas um esforço transdisciplinar para ações integradas que possa fazer frente ao desafio ético da desigualdade social entre os afetados pelos efeitos nocivos das mudanças climáticas.

\section{Cities and global warming: challenges for urban planning, engineering and social and basic sciences}

\section{Article info \\ Received 7 February 2020 \\ Received in revised form 8 April 2020 \\ Accepted 12 April 2020}

\section{Keywords}

Global warming

Urban planning

Climate change

Sustainability

\begin{abstract}
This article aims to present a transdisciplinary approach to the relationship between climate change and cities. Part of the recognition that the current form of urbanization in large metropolitan regions is a strong agent that promotes global warming, at the same time that it is the locus of the harmful manifestation of the effects of these changes. The change in rainfall patterns, with greater frequency and intensity, in the distribution of rainfall and the phenomenon of heat islands, particularly affects the most precarious settlement areas, where high social vulnerability exposes gigantic contingents of people to constant flood risks, landslides, lack of drinking water and basic sanitation, and diseases caused by excessive heat. The search for environmental sustainability involves this social dimension, requiring from sciences and techniques a transdisciplinary effort for integrated actions that can face the ethical challenge of social inequality among those affected by the harmful effects of climate change.
\end{abstract}

\section{Ciudades y el calentamiento global: desafios para el urbanismo, las ingenierías y las ciéncias sociales y básicas}

\section{Información}

Recibido 7 Febrero 2020

Manuscrito revisado recibido 8 Abril 2020

Aceptado 12 Abril 2020

\section{Palabras clave}

Calentamiento global

Urbanismo

Cambios climáticos

Sostenibilidad

\section{Resumen}

Este artículo tiene como objetivo presentar un enfoque transdisciplinario de la relación entre el cambio climático y las ciudades. Parte del reconocimiento de que la forma actual de urbanización en las grandes regiones metropolitanas es un fuerte agente que promueve el calentamiento global, al mismo tiempo que es el lugar de manifestación nociva de los efectos de estos cambios. El cambio en los patrones de lluvia, con mayor frecuencia e intensidad, en la distribución de las lluvias y el fenómeno de las islas de calor, afectan particularmente a las áreas de asentamiento más precarias, donde la alta vulnerabilidad social expone gigantes contingentes de personas a constantes riesgos de inundaciones. deslizamientos de tierra, falta de agua potable y saneamiento básico, y enfermedades causadas por el calor excesivo. La búsqueda de la sostenibilidad ambiental involucra esta dimensión social, requiriendo desde las ciencias y técnicas un esfuerzo transdisciplinario para acciones integradas que puedan enfrentar el desafío ético de la desigualdad social entre los afectados por los efectos nocivos del cambio climático.

\footnotetext{
* Autor correspondente em: Programa de pós-graduação em Arquitetura e Urbanismo, Universidade de São Paulo, campus São Carlos. 


\section{Mudanças climáticas antrópicas e os de- safios para o planejamento urbano}

A cidade de São Paulo foi implantada em um território constituído por densa rede hídrica que condiciona sua urbanização até os dias atuais. O território montanhoso gera uma enorme quantidade de córregos, que convergem para os rios Aricanduva, Pinheiros, Tamanduateí e Tietê, formando amplas planícies fluviais. Foi sobre essa complexa geomorfologia que se construiu o sistema viário estrutural, composto pelas avenidas marginais, nas principais planícies fluviais, alimentadas pela rede de avenidas de fundo de vale. Se essa prática já estava presente na primeira metade do século XX, no Plano de Avenidas de Prestes Maia, os planos subsequentes transformaram os talvegues, várzeas e fundos de vale em eixos de expansão da urbanização.

Travassos (2010) e Gronstein (2001) apontam a institucionalização dessa prática, transformada em política pública na década de 1970 com recursos federais e estaduais para canalização de córregos para a construção de ruas e avenidas. Ao mesmo tempo que ocultava o esgoto lançado sem tratamento no curso d'água, tornava viável a comercialização de áreas alagáveis, essenciais para que os ciclos dos rios não oferecessem riscos. Ao mesmo tempo que a retificação, canalização e tamponamento dos cursos d'água gerou espaço para a construção da cidade, edifícios e vias, estabeleceu vínculos permanente entre os fluxos das águas e o dos veículos.

A alteração dos regimes hídricos (SILVA DIAS, 2013), com a maior frequência de chuvas intensas, torna obsoleto os parâmetros de chuva de projeto consolidados pela engenharia de infraestrutura ao longo do século XX. Estudos recentes apresentam projeções alarmantes para o agravamento dos extremos de chuva, seca e calor na RMSP.

Considerando as médias entre 1971 e 2000, Resenzweig e Solecki (2018) preveem o cenário mostrado na tabela 1 para as próximas décadas. O forte crescimento da amplitude nos extremos positivos e negativos dos índices de precipitação agravarão violentamente a situação de enchentes, deslizamentos e secas em um prazo de vinte,
Tabela 1. Evolução das médias de temperatura e precipitação (RESENZWEIG; SOLECKI, 2018).

\begin{tabular}{ccc}
\hline Ano & Temperatura $\left({ }^{\circ} \mathbf{C}\right)$ & Chuva (\%) \\
\hline 2020 & $+0,9 a+1,7$ & $-31 a+43$ \\
2040 & $+1,7 a+3,6$ & $-32 a+58$ \\
2080 & $+2,1 a+6$ & $-38 a+81$ \\
\hline
\end{tabular}

quarenta e oitenta anos.

Projetadas de acordo com parâmetros de vazão cada vez mais ultrapassados pelas mudanças climáticas, os dispositivos de escoamento e retenção das águas pluviais não cumprem mais a função de evitar transbordamentos. Resulta assim em maior frequência e intensidade de inundações do sistema viário e das áreas edificadas lindeiras, com elevados danos às pessoas que moram, trabalham ou circulam nessas áreas. A insuficiência da infraestrutura é ainda mais grave nas regiões de ocupação informal e precária, onde são frequentes os deslizamentos de encostas devido às deficiências e/ou ausência de sistemas de drenagem superficial adequado.

Pesquisas sobre o clima em área urbana apontam que tais alterações em São Paulo são decorrentes de fatores antrópicos locais, tais como a forma da urbanização e as emissões de gases de efeito estufa por motores veiculares (NOBRE et al, 2011). Consideramos que tal combinação cria um desafio de caráter socioambiental, o de evitar os danos sociais causados pelos desequilíbrios ambientais. Para superá-lo é necessária a ação integrada nas áreas de planejamento e projeto urbano, engenharias de transportes, hidráulica, solos.

O Plano Diretor Estratégico PDE elaborado entre 2013 e 2014 foi a revisão do plano de 2002, conforme previsto pelo Estatuto da Cidade. O momento de sua elaboração coincide com as primeiras consolidações de estudos científicos que reconheceram os impactos das mudanças climáticas na Região Metropolitana de São Paulo - RMSP. Ao longo desta última década, intensificaram-se a frequência e a intensidade de eventos extremos como inundações, escassez de água potável, deslizamentos de terra e ilhas de calor. Em função do padrão de urbanização paulistano, a alteração do regime de chuvas provoca os três primeiros fenômenos - enchentes 


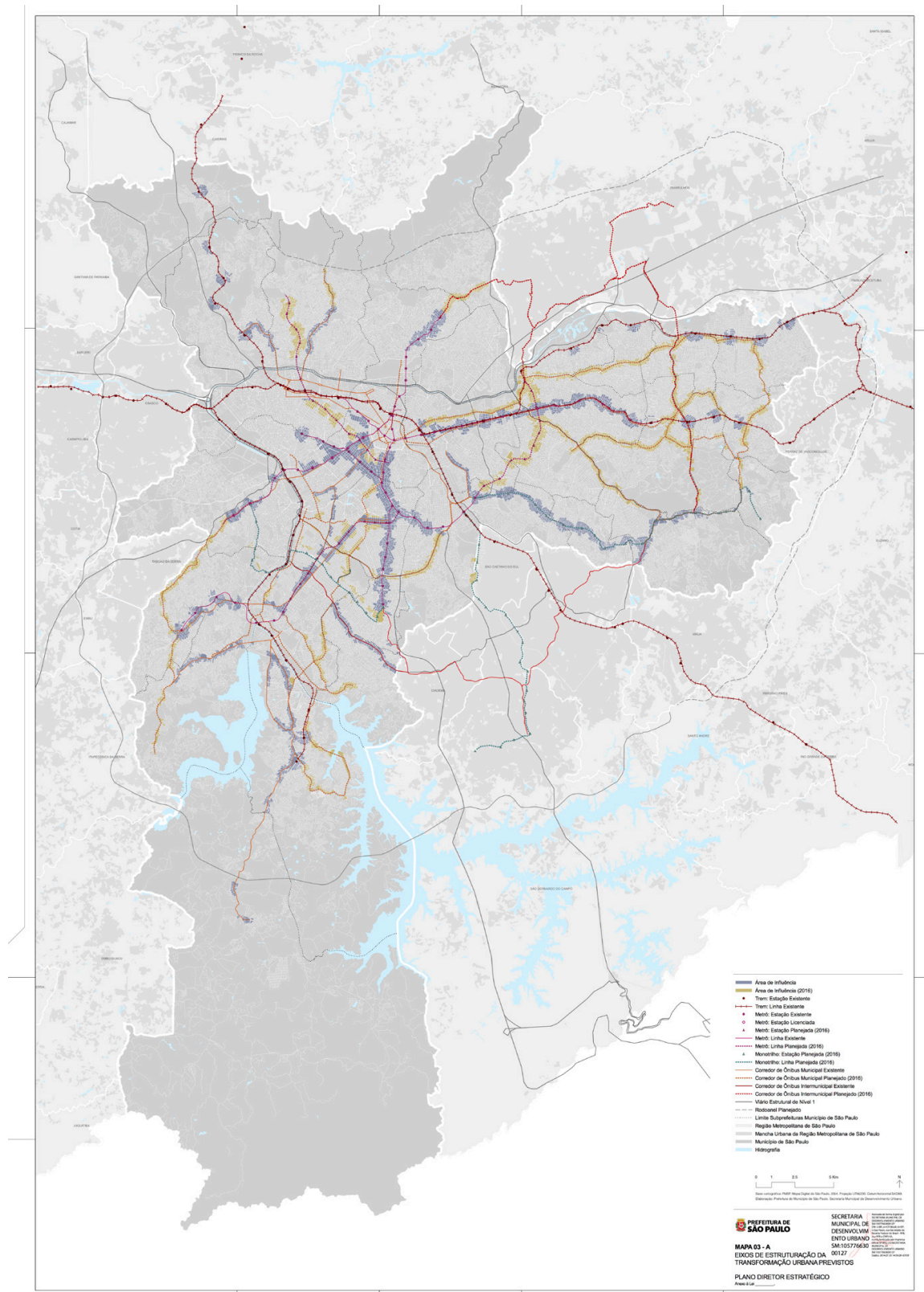

Fig. 1. Mapa Eixos de Estruturação da Transformação Urbana. Plano Diretor Estratégico de 2014. Gestão Urbana.

e deslizamentos em áreas urbanizadas combinada com a falta de água potável. A formação de ilhas de calor decorre de combinação mais complexa, entre o padrão de mobilidade baseado em veículos automotivos geradores de Gases de Efeito Estufa, a necessidade de grandes deslocamentos diários e a predominância de superfícies reflexivas.

O PDE 2014 estabelece várias diretrizes para a redução desses fatores, tais como ampliar o uso de transporte público, reduzir a necessidade de deslocamentos pendulares diários entre casa e trabalho e conter a expansão horizontal da área urbana.

Um dos principais pilares do Plano Diretor Estratégico de São Paulo foi um quadro de instrumentos urbanísticos apoiado na rede de infraestrutura de transporte de alta capacidade, existente e planejada. Corredores de ônibus e linhas de metrô e trens configuraram a malha dos Eixos de Estruturação da Transformação Urbana - EETU, instrumento do PDE que visa a distribuição linear do adensamento, formando faixas verticalizadas pelo território urbano. Pretendeu-se evitar tanto o crescimento espraiado horizontal, quanto a concentração excessiva no centro expandido.

No que se refere à mobilidade urbana, os EETU tiveram como objetivo estimular a substituição de viagens de automóveis pelas de transporte público de alta e média capacidade, oferecendo mais moradia e emprego a distância de caminhada dos pontos de embarque e desembarque. 0 


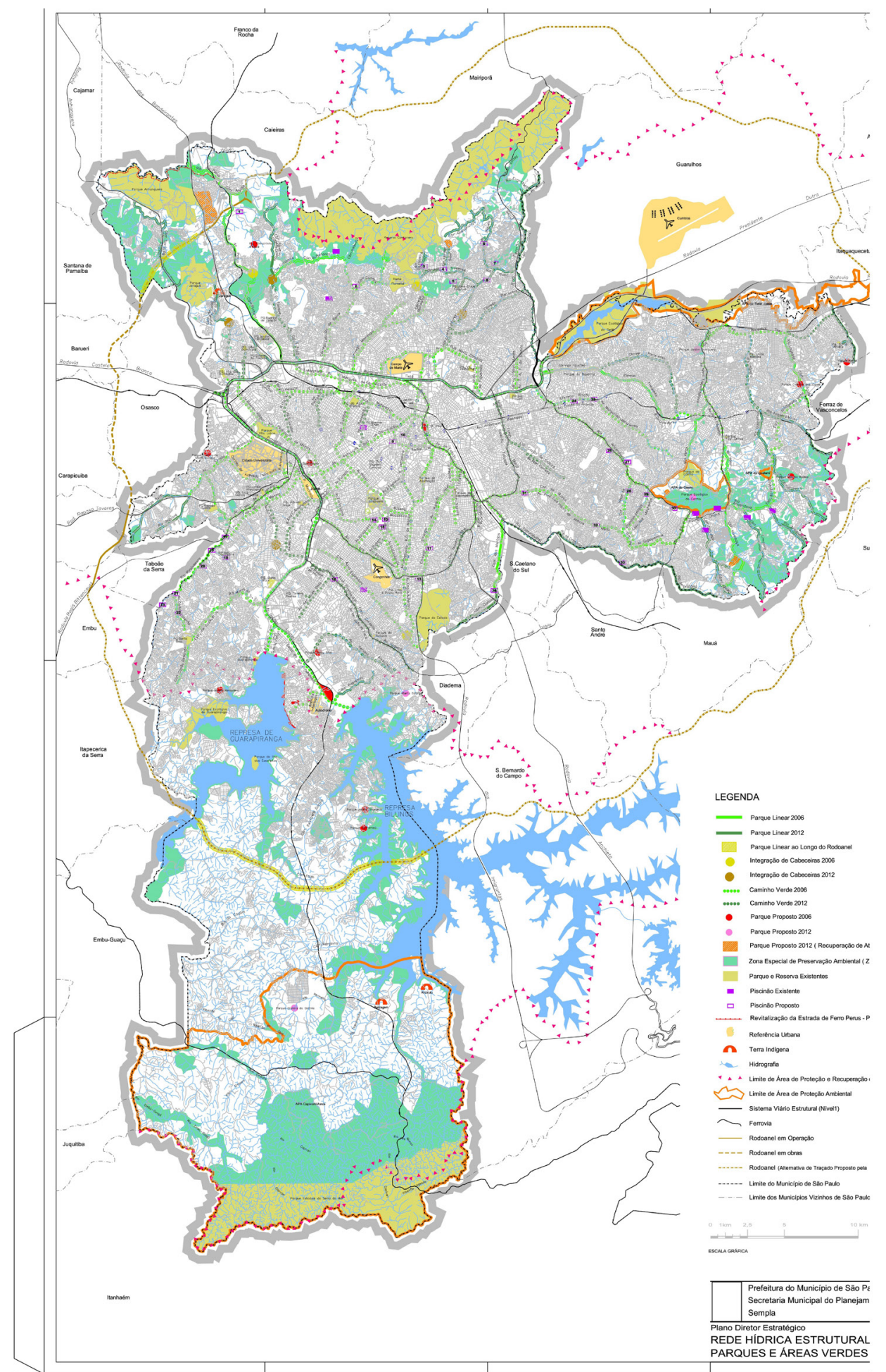

Fig. 2. Mapa de Rede Hídrica Estrutural. Plano Diretor Estratégico de 2002. Gestão Urbana.

incentivo ao uso misto das novas edificações nos EETU visa reduzir a própria necessidade de grandes deslocamentos diários, pois distribui mais homogeneamente as atividades geradoras de emprego e as moradias. Enfrenta assim duas condições que degradam as condições ambientais de São Paulo.

Já apontamos em outras ocasiões os riscos de agravamento das enchentes decorrentes da associação entre o sistema viário estrutural que coincide com a rede hidrográfica com os adensamentos lindeiros aos corredores de ônibus.

\section{Planejamento e gestão da drenagem urbana}

Para a evitar as enchentes mais graves, as estratégias do PDE 2014 foram divididas em duas frentes. Na escala do lote, estabeleceu a cota ambiental, que premia quem utiliza alguns 


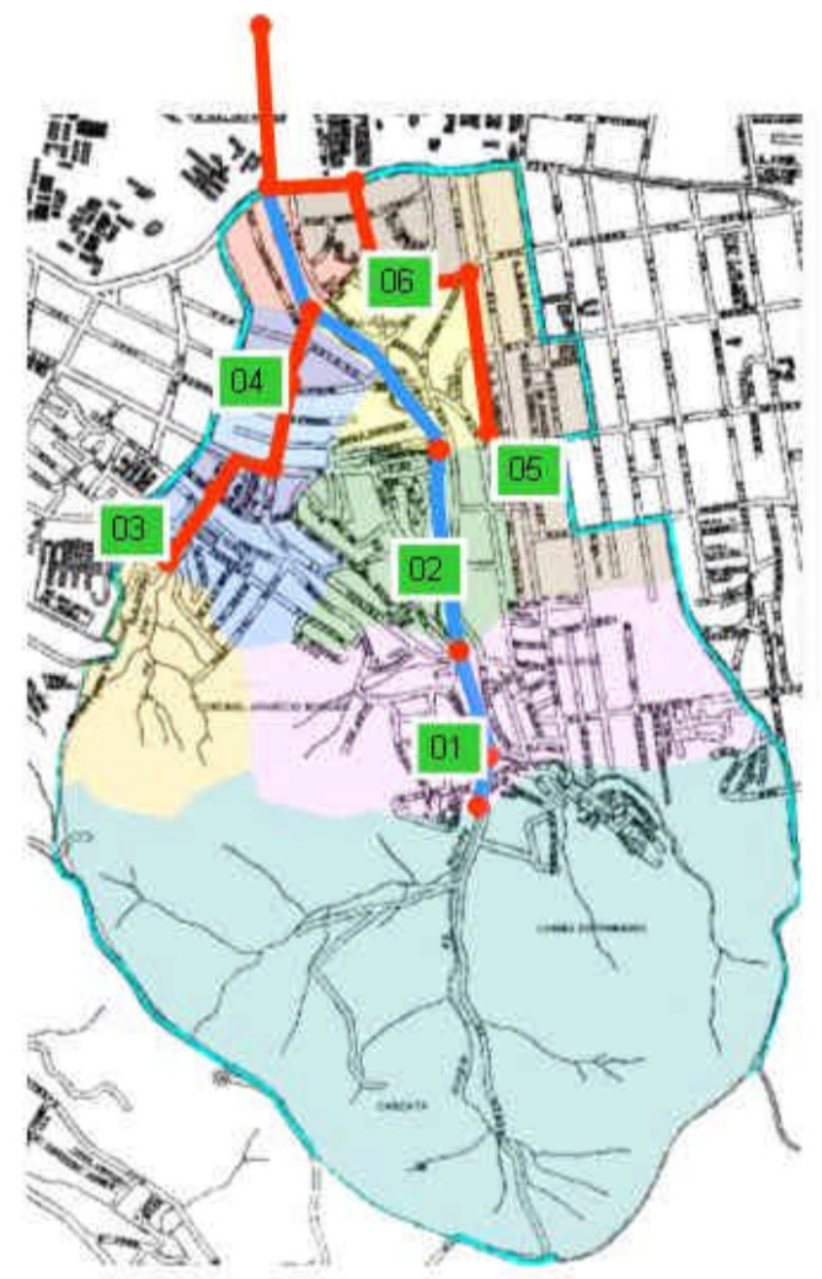

Fig. 3. Mapa de dispositivos de contenção de enchentes na Bacia do Arroio do Moinho, Porto Alegre (SOUZA et al, 2012).

dispositivos de retenção e absorção das águas pluviais no empreendimento. Na escala territorial, definiu um Sistema de Saneamento Ambiental que integra abastecimento de água, esgotamento sanitário, drenagem e resíduos sólidos, prevendo um Plano Diretor de Drenagem Urbana. Contudo, a gestão dos planos específicos de bacias hidrográficas é gerida pela Secretaria Municipal de Infraestrutura Urbana e Obras - SIURB, sendo contratados de acordo com prioridades que nem sempre coincidem com as definidas pela Secretaria Municipal de Desenvolvimento Urbano - SMDU e desenvolvidos sem coordenação entre elas.

Os planos de macrodrenagem deveriam servir de base para o detalhamento do PDE na escala dos bairros, ou seja, nos Planos Regionais, o que não acontece. Resulta em um descompasso que impede que a construção dos instrumentos que definem o uso e ocupação do solo (Zoneamento, Planos Regionais, Planos de Intervenção Urbana, Área de Estruturação Local) considerem as condições objetivas das bacias hidrográficas e suas áreas de risco. Desse modo, o combate às enchentes se torna estritamente uma ação de infraestrutura de caráter corretivo estritamente setorial, sem poder se aproveitar de instrumentos urbanísticos de caráter preventivo ou não-estrutural.

Os sistemas de drenagem urbana desenvolvidos a partir dos anos 1990, tais como Low Impact Development LID, Water Sensitive Urban Design WSUD e Sustainable Drainage Systems SuDS estabelecem a integração da drenagem e outras redes de infraestrutura com o planejamento e projeto urbano, de áreas verdes de lazer.

A partir do início deste século, alguns municípios procuraram incorporar essas abordagens em seus projetos de drenagem. Em 2006 o Ministério das Cidades lançou o programa "Drenagem Urbana Sustentável", incentivando os municípios utilizarem técnicas de LID em seus planos de macrodrenagem. A iniciativa não obteve sucesso, e permanecem as práticas de aceleração da vazão através da canalização em concreto armado e da retenção obtida através de grandes "piscinões". Souza, Cruz e Tucci (2012), acusam a falta de capacidade gerencial para a aproximação de diferentes campos de atuação do poder executivo como responsável pelo insucesso.

Travassos e Schult (2013) analisam detalhadamente as dificuldades de ação integrada de secretarias municipais de São Paulo, na articulação de programas com o objetivo de "dar espaço para o rio respirar", uma diretriz básica dessas novas concepções de macrodrenagem do Plano Diretor Estratégico de 2002. No artigo 106, o PDE 2002 criou a Rede Hídrica Estrutural, enfatizando o papel múltiplo dos fundos de vales para drenagem, lazer e meio ambiente. Para sua implementação, estabeleceu a utilização do instrumento urbanístico Áreas de Intervenção Urbana - AIU (inciso VI do artigo 146) "porções do território de especial interesse para o desenvolvimento urbano, objeto de projetos urbanísticos específicos, nas quais poderão ser aplicados instrumentos de intervenção, previstos na Lei Federal $\mathrm{n}^{0}$ 10.257, de 10 de julho de 2001 - Estatuto da Cidade, para fins de regularização fundiária, execução de programas 


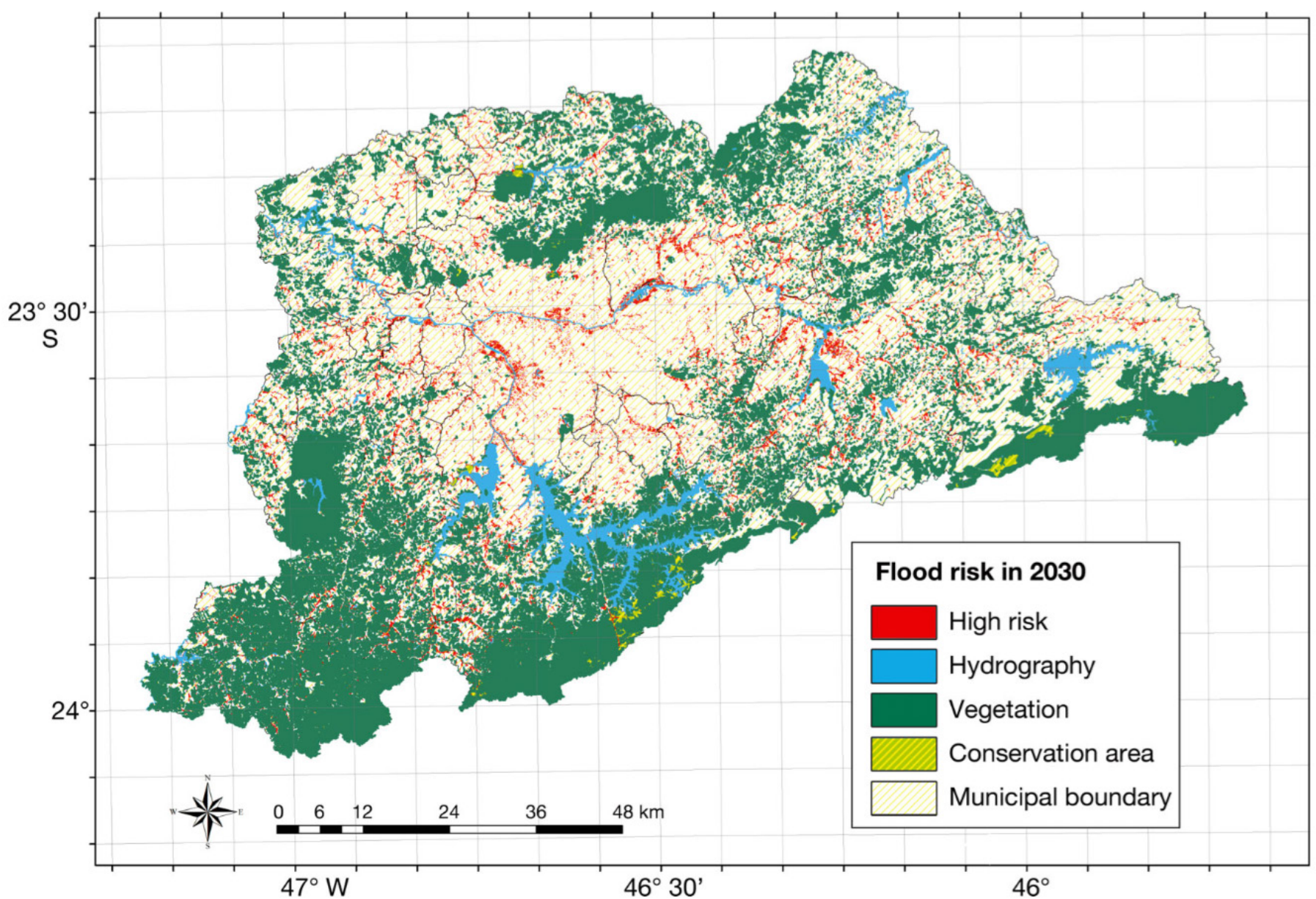

Fig. 4. Simulação da expansão da ocupação urbana na Região Metropolitana de São Paulo (YOUNG, 2013).

e projetos habitacionais de interesse social, constituição de reserva fundiária, ordenamento e direcionamento da expansão urbana, implantação de equipamentos urbanos e comunitários, criação de espaços públicos de lazer e áreas verdes, criação de unidades de conservação ou proteção de outras áreas de interesse ambiental"

Travassos e Schult (2013) demonstram que mesmo dotadas de instrumentos legais, as gestões municipais seguintes não foram capazes de articular as ações de saneamento (programa Córrego Limpo), com a criação do sistema de parques lineares junto aos rios (programa "100 Parques em São Paulo"), e com a necessária remoção e alocação de domicílios em áreas de risco (Plano Municipal de Habitação). Os dois artigos indicam que os limites de gestão são preponderantes frente aos limites técnicos, e que são recorrentes desde o PDE 2002, no mínimo.

Destaque-se a experiência de Porto Alegre nesse período, que realizou seu Plano Diretor de Drenagem Urbana (2003) com abordagem integrada. A partir dele, o Plano de Drenagem Urbana do Arroio do
Moinho introduziu a estratégia de distribuição de pequenas retenções em praças e equipamentos públicos, de baixo impacto urbano, mas capazes de evitar as enchentes na própria sub-bacia e na bacia à jusante.

Aprovado em julho de 2014, o PDE desdobrou-se na nova Lei de Zoneamento, como é popularmente conhecida a Lei de Parcelamento, Uso e Ocupação do Solo LPUOS (2015), Planos Regionais (2016) e no Código de Obras (2016), os quais formaram um conjunto de leis em vigor, que vem regulamentando o desenvolvimento urbano da cidade de São Paulo nos últimos quatro anos.

Dois estudos realizados após a aprovação dessas quatro leis simulam os efeitos do adensamento previsto nos Eixos de Estruturação da Transformação Urbana.

No primeiro, na área de clima, simula seu impacto na distribuição de chuvas em função dos diferentes cenários de crescimento urbano. O outro, da engenharia hidráulica, avalia a impermeabilização do solo estabelecido na nova legislação urbana e 


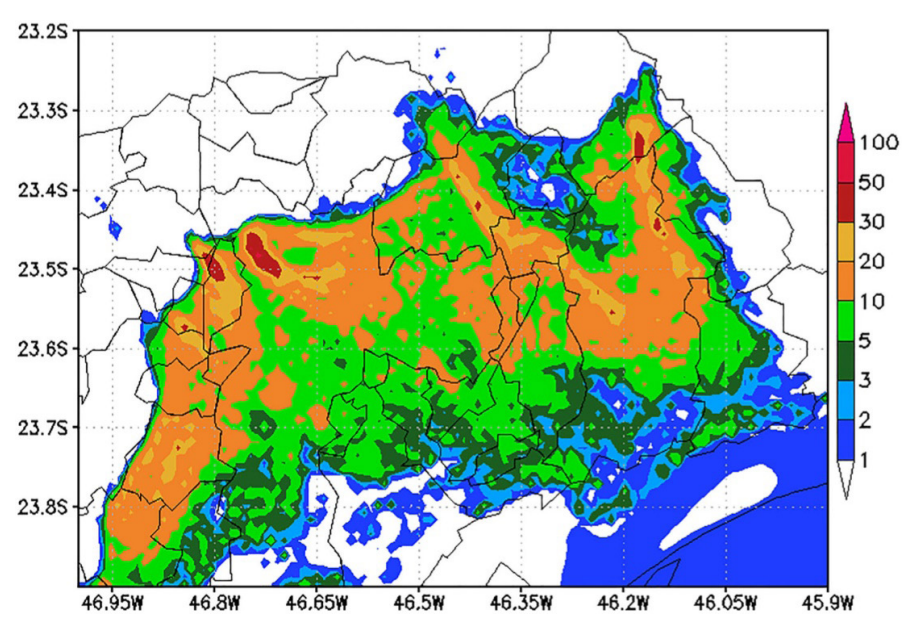

Fig. 5. Experimento 2 de simulação da precipitação sobre a expansão da ocupação urbana realizada por Young, 2013 (BENDER et al, 2019).

seu efeito para a drenagem.

\section{Expansão urbana e clima}

Com o objetivo de entender o impacto da forma urbana no comportamento do clima, em especial das chuvas intensas, Bender, Freitas e Machado (2019) compararam o comportamento de uma chuva ocorrida em São Paulo em 14 de fevereiro de 2013, com dois cenários possíveis para 2030. Um apoiado na continuidade da taxa de crescimento registrada entre 2001 e 2008, outro simulando a aplicação dos parâmetros de contenção da expansão horizontal estabelecidos pelo Plano Diretor Estratégico.

O primeiro cenário foi criado pela simulação da expansão da ocupação urbana na RMSP para 2030 (YOUNG, 2013), realizada a partir de dados do Landsat TM7 utilizando o software Dinâmica EGO, mostra um cenário alarmante de aumento de 38,7\%. Sobre esse cenário, o estudo é muito importante, pois avança em identificar uma ampliação das áreas suscetíveis a deslizamentos em 2008, de 0,9\% para 4,27\% em 2030. O exame amostral dos mapas gerados pela pesquisa, contudo, sugere a necessidade de confrontá-los com outras escalas de análise, de modo a validar os resultados e a metodologia adotada. Como a simulação de Young foi feita em paralelo à elaboração do PDE 2014, não foram nele incorporadas as suas diretrizes de redistribuição do adensamento.

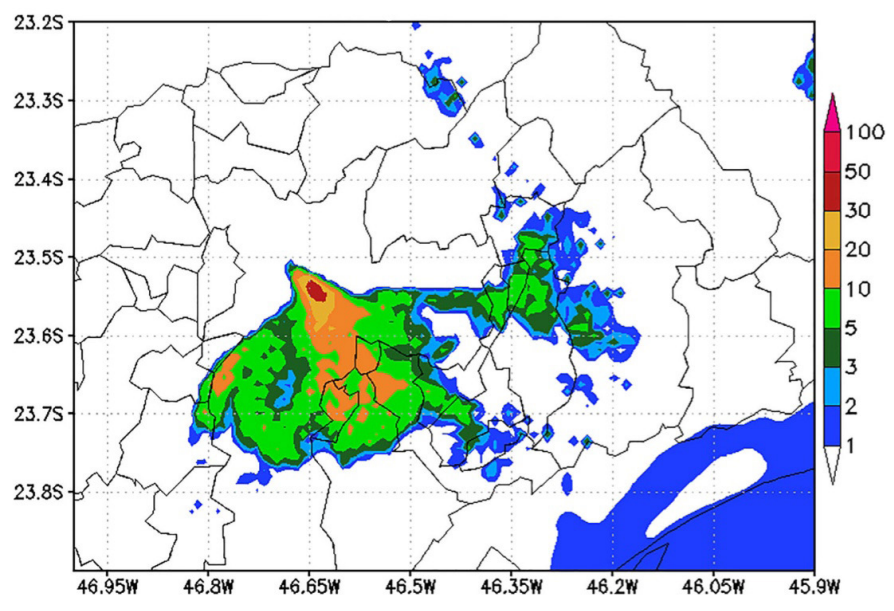

Fig. 6. Experimento 3 de simulação da precipitação sobre a expansão da ocupação urbana proposta pelo PDE 2014 (BENDER et al, 2019).

Nesse sentido a abordagem de Bender, Freitas e Machado (2019) traz importante contribuição de método, pois simulam a cidade gerada pelos , as diretrizes de adensamento linear do PDE, com maior altura dos edifícios, para estudar seu impacto na distribuição de chuvas na RMSP, comparando-a com os efeitos do cenário criado por Young.

O resultado do estudo demonstra que as estratégias urbanísticas propostas no zoneamento do PDE alteram significativamente a tendência "espontânea" de espraiamento do crescimento estabelecida por Young.

Define assim quatro experimentos. O primeiro, para validação do modelo, foi o da própria tempestade ocorrida em 2014 na cidade existente na época. Os dois seguintes puderam comparar as duas simulações da área urbana em 2030. O quarto experimento previu a distribuição dos edifícios mais altos em toda a área de urbanização prevista por Young, o que resultado de um hipotético descontrole total desse processo.

Enquanto experimento 2, sobre o estudo de Young, mostra a um aumento de volume da precipitação, distribuída por toda a área densamente urbanizada da RMSP, em especial na Zona Leste, o experimento 3, sobre a simulação de Bender, indica um menor volume de precipitação, concentrado nas áreas mais verticalizadas do Centro e na Zona Sul da cidade de São Paulo.

No experimento 2, o maior volume de chuva decorre do aumento da temperatura na superfície, 


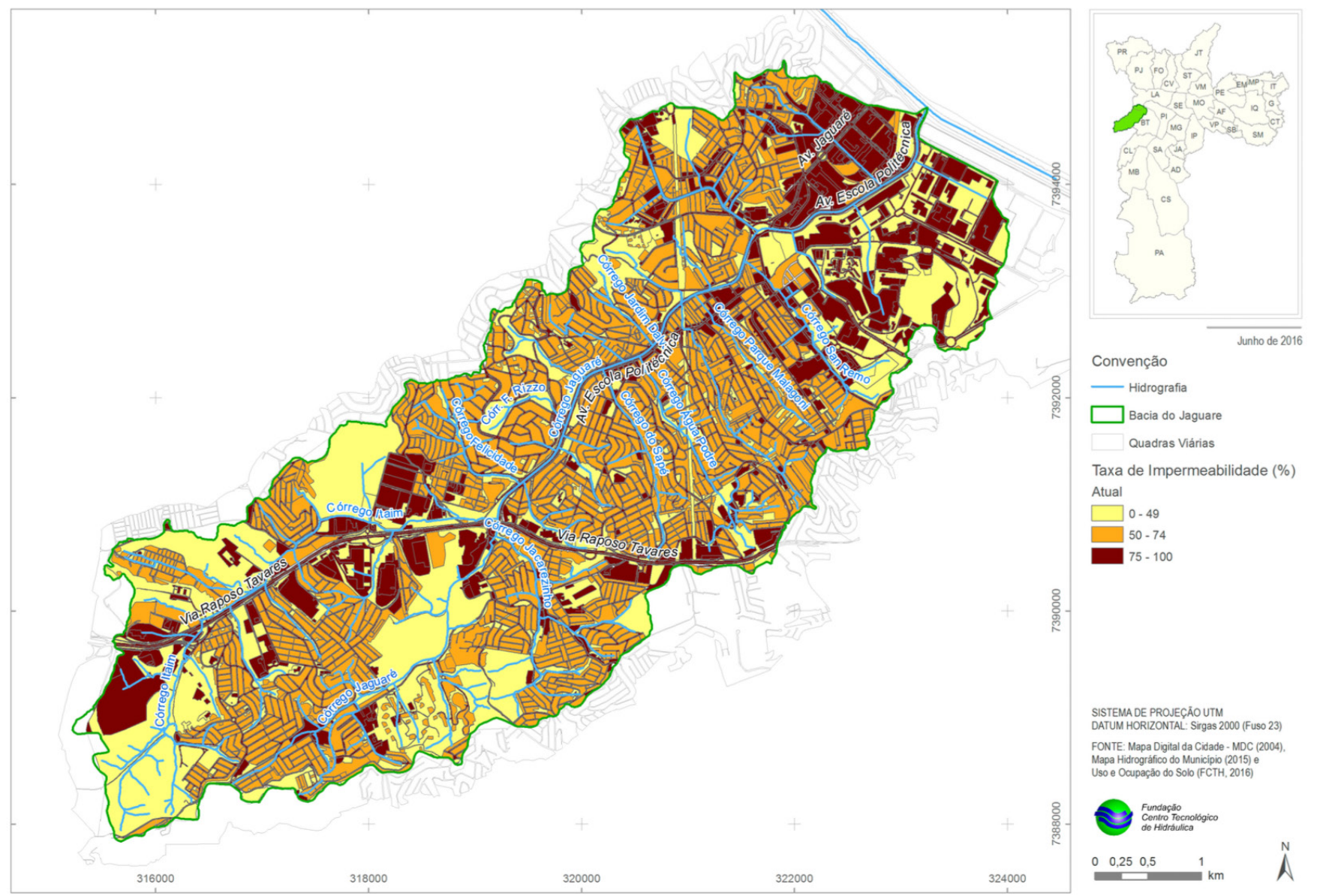

Fig. 7. Taxa de impermeabilização da bacia do Jaguaré atual (Caderno FCTH, 2016).

onde ocorre a remoção da vegetação para a urbanização. A redução do volume de chuva no experimento 3 decorre da redução da temperatura na superfície do solo em função da maior altura dos edifícios, que também são responsáveis pelo desvio das brisas do mar das áreas centrais mais quentes, que passariam por sobre a área urbana em direção norte.

Essa diferença tem impacto regional na distribuição das chuvas que garantem o abastecimento de água potável para a RMSP. A menor precipitação na RMSP significa que o ar úmido vindo do oceano consegue ultrapassá-la e chegar aos reservatórios do sistema Cantareira, situados a norte. Os cenários urbanos dos outros três experimentos explicam como a forma da área urbanizada, extensa e horizontal, força a precipitação precoce das brisas úmidas marítimas sobre a cidade, causando enchentes ao mesmo tempo que deixa de recarregar os reservatórios do sistema Cantareira, levando à escassez de água potável.

\section{Engenharia hidráulica e urbanismo}

Os cadernos de bacia hidrográfica elaborados pela Fundação Centro Tecnológico de Hidráulica FCTH para a Secretaria Municipal de Infraestrutura e Obras Siurb realizam o diagnóstico da bacia e apresentam propostas para combate às enchentes. Apesar da gravidade das enchentes no município, estão disponíveis para consulta os cadernos de apenas 6 bacias $^{1}$, sendo que somente 3 englobam grandes áreas de EETU ao longo do córrego.

Os cadernos são básicos para a tomada de decisão pela prefeitura sobre quais projetos de dispositivos serão desenvolvidos. A priorização é feita pela SIURB, que tem seus critérios independentes da SMDU e SP Urbanismo, responsáveis pela aplicação das diretrizes do PDE.

1 Cabucú de Baixo (ZEU e ZEIS), Jacú (ZEU e OU), Morro do $S$ (ZEU, ZEIS, ZM). ). Águas Espraiadas tem uma ZEU nas cabeceiras, mas é predominantemente ZER_1, ZC e ZM. As demais são Jaguaré (ZC, ZM e ZOE - USP), Mandaqui (ZM e ZC). Há informações de que mais cinco cadernos estão concluídos e serão divulgados ainda em 2020 - córregos Sumaré, Água Preta, Uberaba, Pirajuçara e Aricanduva. Estão contratados os cadernos de drenagem dos córregos Verde (Pinheiros), Anhangabaú, Tiquatira, Itaquera, Tremembé e CEAGESP. 


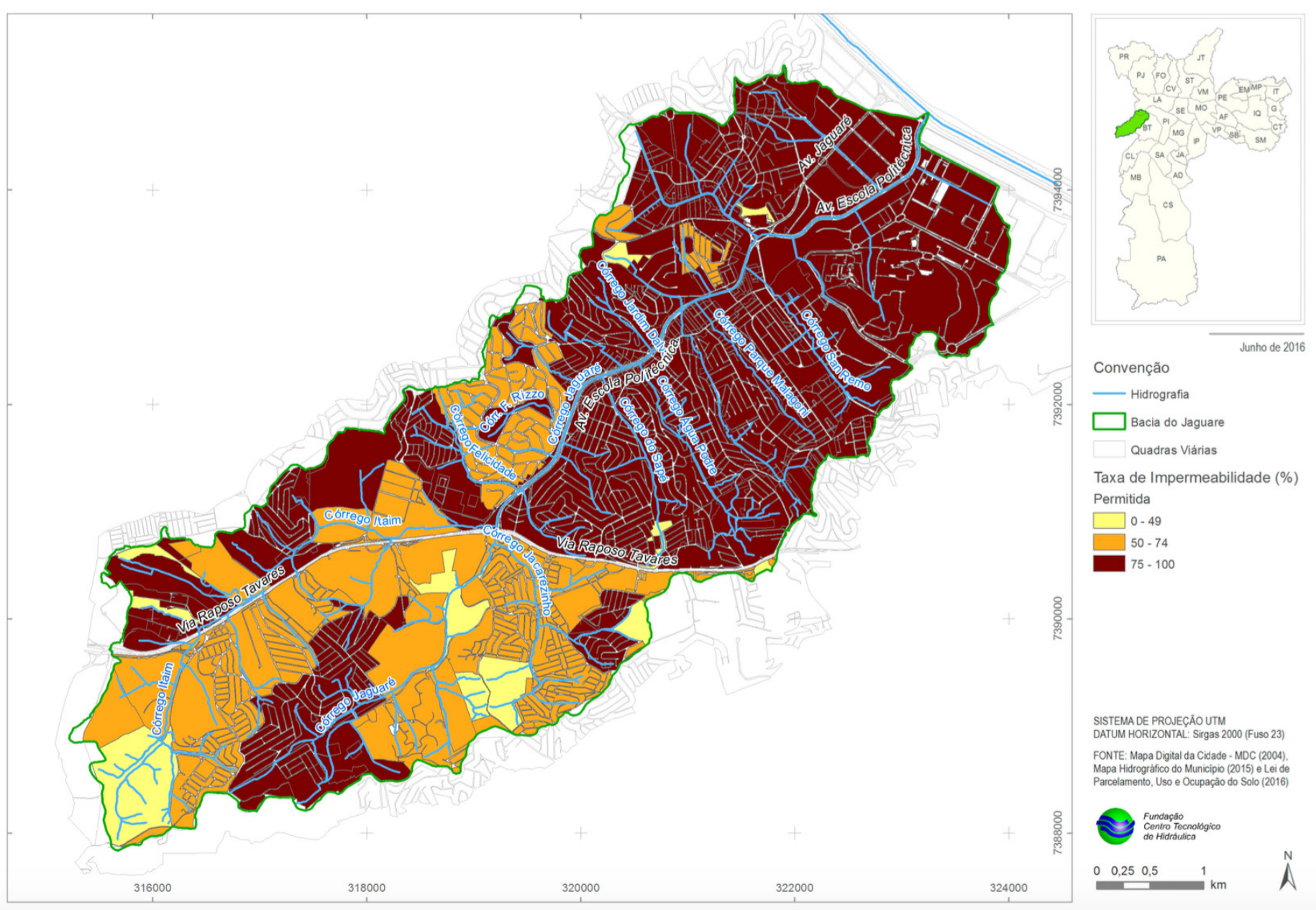

Fig. 8. Taxa de impermeabilização da bacia do Jaguaré futura (Caderno FCTH, 2016).

O método aplicado pela FCTH é o do Departamento de Agricultura dos Estados Unidos, o Natural Resources Conservation Service (NRCS), no qual várias características da urbanização geram fatores para o cálculo do volume de vazão. As variações do uso e ocupação do solo determinam as taxas de impermeabilização e os índices de escoamento. Quanto mais o solo é coberto por revestimentos impermeáveis - pavimentos e construções, menor a permeabilidade e maior o excedente de água que corre para o exutório. A taxa de impermeabilização atual é estimada a partir dos levantamentos do existente, enquanto para as taxas futuras, a FCTH utilizou a Lei de Parcelamento, Uso e Ocupação do Solo - LPUOS. Nela estão definidas as taxas de permeabilidade mínima para as futuras construções por tamanho do lote, que é de 15\% em lotes menores de $500 \mathrm{~m}^{2}$, e $25 \%$ nos maiores. Para efeito de cálculo, os cadernos consideram um horizonte de ocupação máxima dentro desses limites. Contudo, a impermeabilização da bacia atual não atinge o máximo do permitido pela legislação anterior. Quando comparadas, a evolução na impermeabilização das bacias estudadas é alarmante.

As limitações da comparação precisam ser mais bem avaliadas, em especial se considerarmos os ritmos passados de crescimento da cidade, como fez Young em sua simulação para 2030, usando uma média da expansão urbana entre 2001 e 2008. São claros os efeitos de distorções da simulação da taxa de impermeabilização futura no dimensionamento, planejamento e distribuição de dispositivos de combate à enchente, as quais influem diretamente na tomada de decisões na definição das prioridades.

O cálculo da impermeabilização pelo máximo da ocupação desconsidera ainda os instrumentos urbanísticos do PDE e da LPUOS, previstos para serem usados para atenuar a o crescimento excessivo do volume de vazão de águas pluviais, tais como a Quota Ambiental e os Projetos de Intervenção Urbana em terrenos de grande área. 


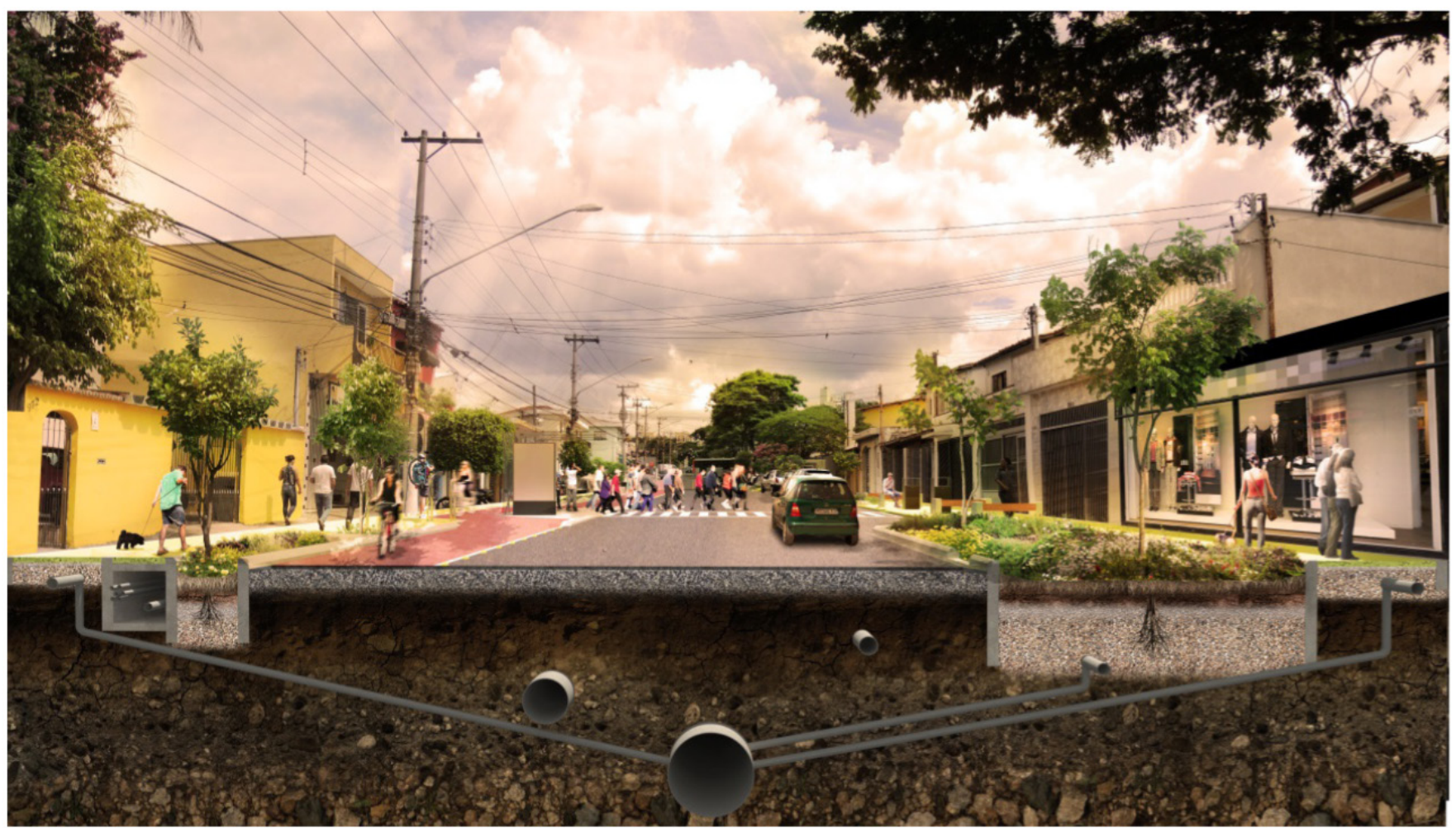

Fig. 9. Corte esquemático de rua adaptada com dispositivos LID (MARQUES et al, 2018).

A descoordenação entre o setor de infraestrutura e o de urbanismo manifesta-se desde a escolha das bacias a serem estudadas, até nos critérios adotados no estudo. Repetem-se os problemas do período de 2005 a 2012 que comprometeram a implantação dos parques lineares, conforme já apontado por Travassos e Schult (2013).

\section{Novos paradigmas técnicos e seus limites frente a realidade urbana/ambiental de São Paulo}

Os seis cadernos de bacia hidrográfica disponibilizados em 2016 apresentam um amplo leque de opções técnicas no projeto de dispositivos de prevenção de enchentes, incorporando parques lineares com função de amortecimento e acomodação das cheias. Fica claro o esforço da engenharia hidráulica, liderado pela FCTH (Poli USP) em parceria com o LabVerde (FAU USP), em introduzir alternativas ao paradigma técnico dos parques lineares e retenções, introduzindo parâmetros de infraestrutura verde no lugar das canalizações com paredes de concreto armado cruzando áreas verdes².

2 Técnica usada na primeira geração de parques lineares, que tem no Parque Tiquatira (2008), na Zona Leste, seu maior exemplo.
Os estudos realizados no Projeto Jaguaré ${ }^{3}$ dentro do plano de despoluição do Rio Pinheiros (MARQUES et al: 2018), incorpora princípios de LID associados aos de Infraestrutura Verde. Os estudos não se limitam às proximidades do curso d'água no fundo de vale, distribuindo dispositivos por toda a bacia. Os LIDs do tipo jardim de chuva, canteiro pluvial e pavimento permeável são propostos para espaços abertos ao longo de vias públicas e edifícios. Ampliam os dispositivos propostos para os parques lineares, criando uma rede "multifuncional e interconectada", associada a grandes bacias de detenção e retenção também concebidas com infraestrutura verde. Segundo Marques (2018:20), tais bacias teriam a função de amortecer os impactos de chuvas com tempo de recorrência de 100 anos, podendo assim ter uso paisagístico. Trata-se de uma linha de investigação consistente e inovadora, que enfrenta o desafio de associar as LID e as Infraestrutura Verde às condições reais da cidade brasileira.

Uma outra linha de investigação, associada aos instrumentos urbanísticos e diretrizes do PDE, vem 3 Projeto realizado entre dezembro/2015 e julho/2017 em articulação com a "Associação Águas Claras do Rio Pinheiros", sob a coordenação técnica da Fundação Centro Tecnológico de Hidráulica (FCTH), com a participação do Labverde (FAUUSP) e financiamento do Fundo Estadual de Recursos Hídricos (FEHIDRO). 


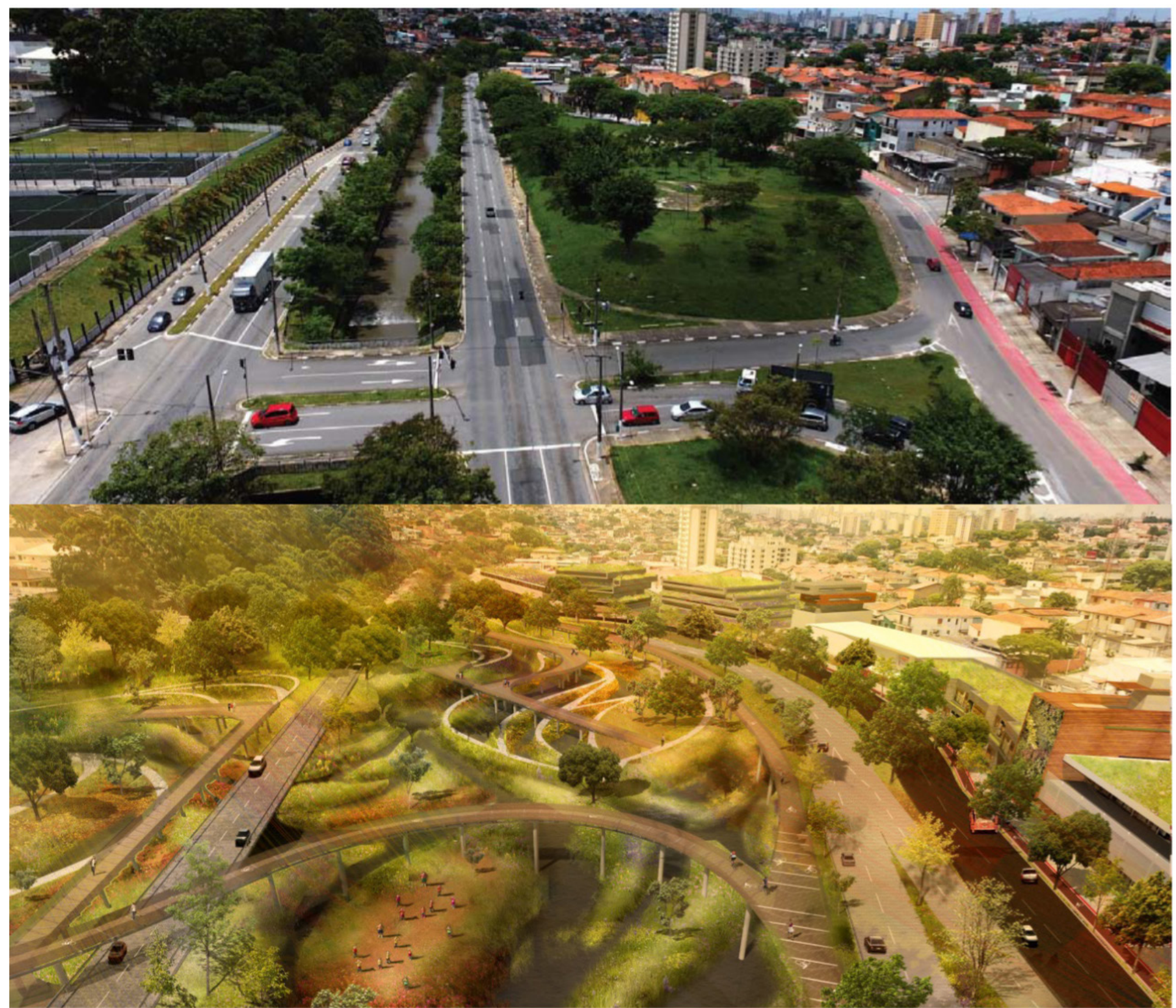

Fig. 10. Projeto de dispositivo de retenção de cheias na bacia do Jaguaré (MARQUES et al, 2018).

sendo desenvolvida sob coordenação deste autor. Os dois estudos de caso realizados estão associados a fundos de vale ocupado (ou a ser ocupado) por corredor de ônibus, fazendo parte de um EETU.

Durante o período de revisão do PDE e elaboração da LPUOS, em 2014, pesquisadores e estudantes do Instituto de Arquitetura e Urbanismo e Escola de Engenharia de São Carlos realizaram estudos urbano-ambientais em duas bacias na periferia de São Paulo, a do Lageado, Zona Leste e a do Cabuçú de Baixo, Zona Norte. Como ambas as bacias escolhidas não possuíam estudos hidrológicos de drenagem na época, o enfoque desses trabalhos foi o de analisar os conflitos entre as redes de infraestrutura e as condições urbanas existentes, procurando nos instrumentos urbanísticos do PDE possibilidades de diretrizes para projetos locais.

A bacia do córrego do Lageado abrange duas subprefeituras, Itaim Paulista e Guaianases, tendo suas cabeceiras no município Ferraz de Vasconcelos. De acordo com o PDE, a região receberia um corredor de ônibus ao longo da avenida Dom João Neri, a qual segue próxima ao curso d'água, mas fora da sua Área de Preservação Permanente. O problema colocado foi o de aproveitar o EETU proposto para acompanhar o corredor de ônibus e conceber um processo de renovação urbana que integrasse a infraestrutura viária ao plano de drenagem, incorporando o reassentamento dos moradores de áreas de risco e a criação de um corredor verde.

Para isso foi criado o Corredor Ambiental Urbano, 


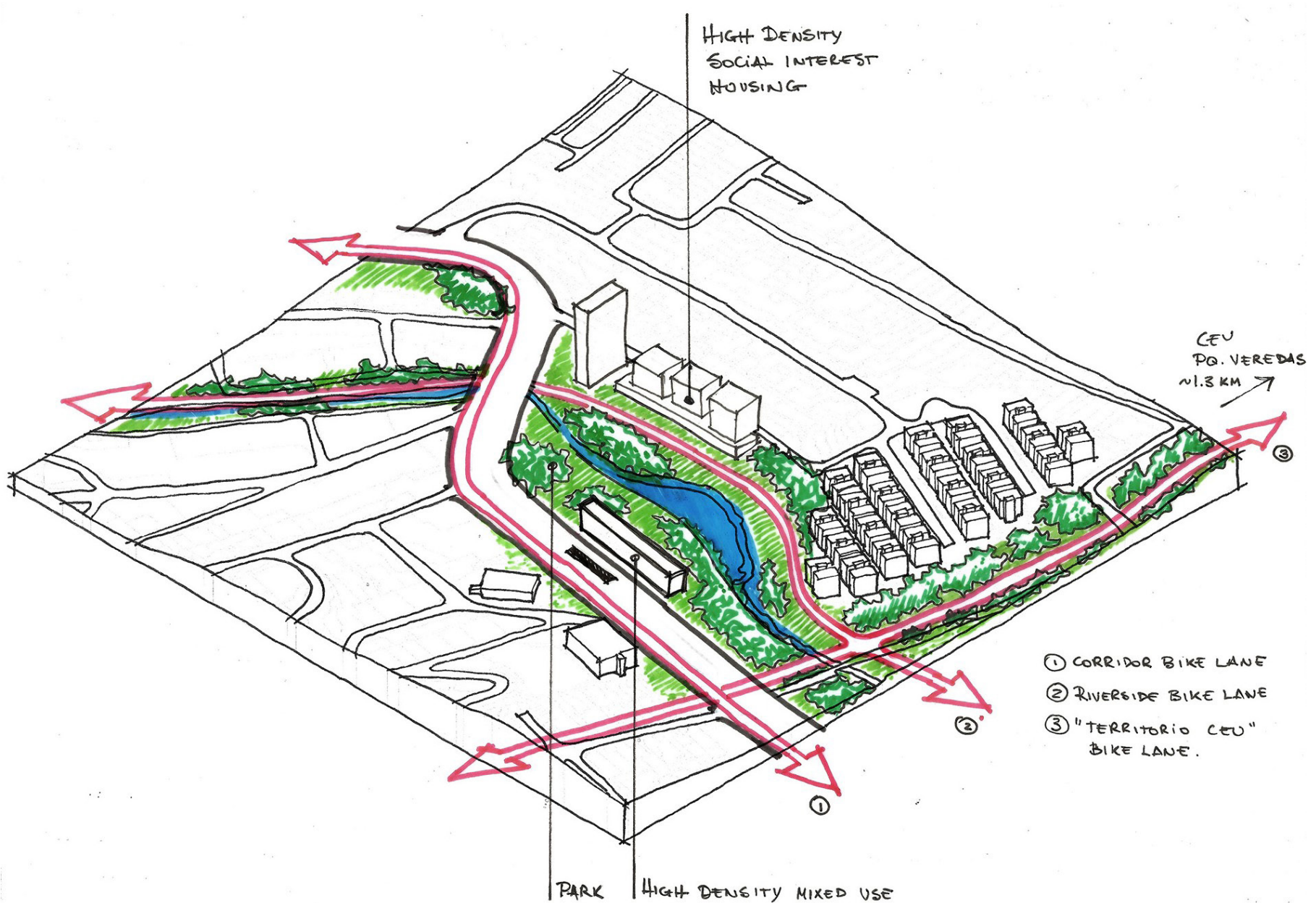

Fig. 11. Corredor Ambiental Urbano na bacia do Lageado, Itaim Paulista (ANELLI; LEITÃO, 2014).

um modelo referencial desenvolvido no workshop "Estudos Urbanos SP: novas linhas de mobilidade" (ANELLI; SANTOS, 2014), promovido em março de 2014 pelo IAU USP em parceria com a HCU Hamburgo, Engenharia Ambiental da EESC USP e SMDU de São Paulo 4 .

Ainda no mesmo ano, durante o segundo semestre, foi promovida pela SMDU os Ateliers Ensaios Urbanos, reunindo estudantes e professores de 17 instituições de ensino de Arquitetura e Urbanismo. Entre os projetos desenvolvidos pelas equipes do IAU USP, destaque-se, para este tema, o estudo para a bacia do Cabuçú de Baixo, distribuída nas subprefeituras Freguesia - Brasilândia e Casa Verde - Cachoeirinha ${ }^{5}$.

4 Estudos Urbanos SP: novas linhas de mobilidade. Workshop promovido em março de 2014 sob a coordenação deste pesquisador, faz parte da colaboração entre o Instituto de Arquitetura e Urbanismo da Universidade de São Paulo e a HafenCity Universität de Hamburgo com participação da Engenharia Ambiental da Escola de Engenharia de São Carlos da Universidade de São Paulo e da Secretaria Municipal de Desenvolvimento Urbano de São Paulo. O workshop teve o patrocínio do Centro Alemão de Ciência e Inovação de São Paulo.

5 Composição da equipe.
A avenida Inajar de Souza, onde se localiza o corredor de ônibus, situa-se às margens de canal de concreto armado, sem nenhum afastamento. O estudo propôs um conjunto de regras de remembramentos de lotes e instrumentos para regulação visando a abertura de espaços dentro dos quarteirões para o acolhimento de dispositivos de drenagem.

As estratégias dos dois estudos são complementares. Ações concentradas nos fundos de vale e distribuídas pelas encostas da bacia devem ser concebidas dentro de um mesmo sistema integrado.

O caso da bacia do Lageado no Itaim Paulista teve desdobramentos de pesquisa nos anos seguintes. Em 2015 a USJT passou a participar da pesquisa através da professora Ana Paula Koury, que criou o Lab Itaim Paulista com professores e estudantes de arquitetura, urbanismo e engenharia civil, muitos deles moradores da região. O Lab Itaim Paulista é um laboratório de transformação urbana e planejamento local, que pretende contribuir 


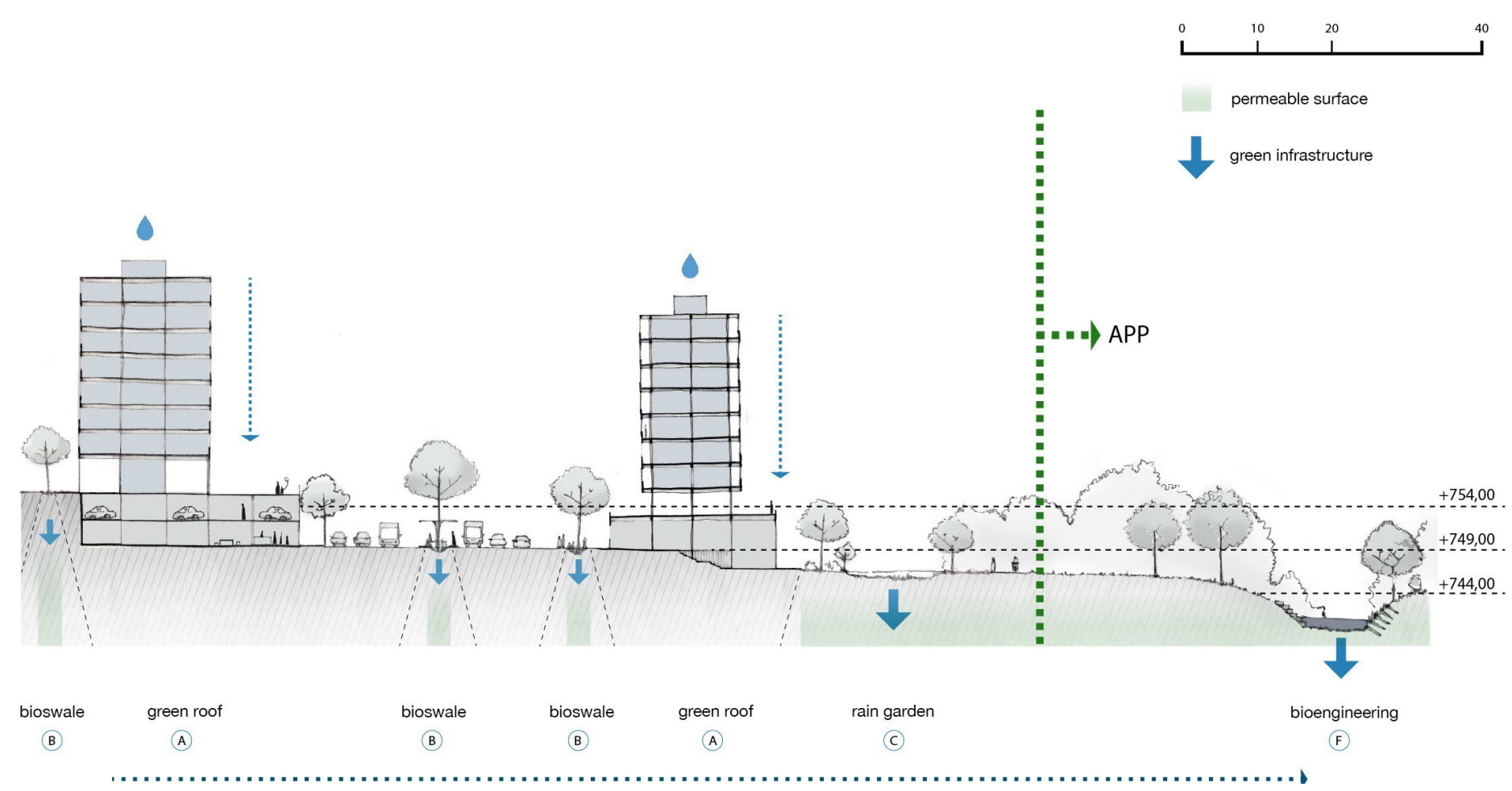

Fig. 12. Plano de drenagem LID na bacia do Lageado, Itaim Paulista (KAZAKU, 2016).

para a integração entre as diferentes escalas de administração da cidade, com o objetivo de melhorar a governança em uma das áreas mais vulneráveis do Município de São Paulo. Através de convênio com a subprefeitura do Itaim Paulista, professores e estudantes contam com uma inserção local permanente, que Ihes permite aprofundar os estudos do aumento da vulnerabilidade urbana da região frente às mudanças climáticas.

\section{Conclusões}

Avaliar a relação entre mudanças climáticas e cidades exige os dois caminhos discutidos aqui. 0 primeiro é entender a urbanização como um forte agente promotor do aquecimento do clima, e no sentido inverso, os efeitos das mudanças climáticas sobre cidades marcadas pela desigualdade social de seus assentamentos. Ao mesmo tempo promotora do aquecimento e vítima dos seus efeitos, as cidades precisam mudar para sobreviver. O trânsito entre os conhecimentos das ciências básicas, ciências ambientais, ciências sociais, engenharias, urbanismo, arquitetura, gestão urbana, entre outras, deve ser propiciado pelo ensino e pesquisa nas universidades que pretendem desempenhar um papel ativo na construção de novos paradigmas de sustentabilidade ambiental. Este artigo introduz um ponto de vista para tal construção.

\section{Referências bibliográficas}

ANELLI, R. L. S.; SANTOS, A. L. Corredores ambientais urbanos: desafios para o desenvolvimento do Plano Diretor Estratégico de São Paulo, articulando as escalas metropolitana, regional e local. In: III ENANPARQ Arquitetura, Cidade e Projeto: uma Construção Coletiva. São Paulo, 2014.

BENDER, A.; FREITAS, E. D.; MACHADO, L. A. T. The impact of future urban scenarios on a severe weather case in the metropolitan area of São Paulo.

Climatic Change, v. 156, p. 471-488, 2019.

CANHOLI, A. P. Drenagem urbana e controle de enchentes. São Paulo: Oficina de Textos. 2005.

FCTH. Desenvolvimento de metodologia e projeto piloto de revitalização de bacia urbana, replicável para as demais bacias da região metropolitana (Bacia do Córrego Jaguaré), Empreendimento 2014 AT-653. Volumes I, II, III e IV, 2017.

FERREIRA, L. S. Vegetação, temperatura de 
superfície e morfologia urbana: um retrato da região metropolitana de São Paulo. Tese (Doutorado em Arquitetura e Urbanismo) Faculdade de Arquitetura e Urbanismo da Universidade de São Paulo. 2019.

FERREIRA, L. S. R.; DUARTE, D. Exploring the relationship between urban form, land surface temperature and vegetation indices in a subtropical megacity. Urban Climate, v. 27, p. 105-123, 2019.

GROSTEIN, M. D. Metrópole e expansão urbana: a persistência de processos "insustentáveis". São Paulo Perspec., São Paulo , v. 15, n. 1, p. 13-19, Jan. 2001.

KAKAZU, P. E. A água como disparador de projeto urbanístico. Pesquisa de Iniciação Científica, bolsa CNPa, Instituto de Arquitetura e Urbanismo, Universidade de São Paulo, São Carlos, 2016.

KOURY, A.; CAVALLARI, T. Desenvolvimento urbano em áreas de fronteira: o caso do Itaim Paulista. Urbe Revista Brasileira de Gestão Urbana, v. 10, n. 1, p. 663-676, 2018.

MARQUES, T. H. N. et al. Projeto Jaguaré: Metodologia para requalificação de bacias hidrográficas urbanas.

Revista eletrônica LABVERDE, n. 9, p. 12, 2018.

NOBRE, C. et al. Vulnerability of Brazilian Megacities to Climate Change: the São Paulo Metropolitan Region (RMSP). In: MOTTA, R.S. et al (Eds). Climate Change in Brazil: economic, social and regularoty aspects. Brasília: IPEA, 2011, p. 197-219.

ROSENZWEIG, C.; SOLECKI, W. Action pathways for transforming cities. Nature Climate Change, v. 8, p. 756-759, 2018. apud MARENGO, J.A. et al. Trends in extreme rainfall and hydrogeometeorological disasters in the Metropolitan Area of São Paulo: a review. Annals of the New York Academy of Sciences, v. 1452, p. 1-16, 2020.

SILVA DIAS, M. A. F. et al. Changes in extreme daily rainfall for São Paulo, Brazil. Climatic Change, v. 116, p. 705-722, 2013.
SOUZA, C. F.; CRUZ, M. A.; TUCCI, C. E. M. Desenvolvimento Urbano de Baixo Impacto: Planejamento e Tecnologias Verdes para a Sustentabilidade das Águas Urbanas. Revista Brasileira de Recursos Hídricos, v. 17, n. 2, p. 9-18, 2012.

STEWART, I. D.; OKE, T. R. Local climate zones for urban temperature studies. Bulletin of the American Meteorological Society, v. 93, n. 12, p. 1879-1900, 2012.

TRAVASSOS, L. R. F. C. Revelando os rios: novos paradigmas para a intervenção em fundos de vale urbanos na Cidade de São Paulo. 2010. Tese (Doutorado em Ciência Ambiental) - Ciência Ambiental, Universidade de São Paulo, São Paulo, 2010.

TRAVASSOS, L.; SCHULT, S.I.M. Recuperação socioambiental de fundos de vale urbanos na cidade de São Paulo, entre transformações e permanências. Cadernos da Metrópole, v. 15, n. 29, p. 289-312, 2013.

YOUNG, A. Urban expansion and environmental risk in the São Paulo Metropolitan Area. Climate Research, v. 57, p. 73-80, 2013. 
Publicação organizada pelo Programa de

Mestrado Profissional Stricto Sensu em

Engenharia Civil da Universidade São Judas

Volume 03 - Edição 01

Janeiro - Dezembro de 2020

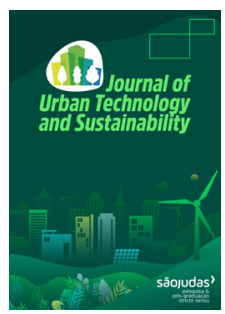

\title{
Contribuição para o desenvolvimento de uma metodologia de dosagem para concreto permeável baseada no desempenho
}

\author{
Ricardo Pieralisji,", Gersson F. B. Sandoval ${ }^{\text {, }}$ Luiz Segura-Castilloc, Medhelin N. C. Barbosa ${ }^{d}$, Stéphany T. Assunção ${ }^{d}$ \\ ${ }^{a}$ Centro de Estudos em Engenharia Civil (CESEC), Programa de Pós-Graduação em Engenharia da Construção Civil (PPGECC), Universidade Federal do Paraná (UFPR), Brasil. \\ ${ }^{b}$ Centro de Tecnologia e Urbanismo (CTU), Programa de Pós-Graduação de Doutorado em Engenharia Civil, Universidade Estadual de Londrina (UEL), Brasil. \\ 'Instituto de Estructuras y Transporte, Facultad de Ingeniería, Universidad de la República (UdelaR), Uruguai. \\ ${ }^{\mathrm{d}}$ Graduanda no curso de Engenharia Civil, Universidade Federal do Paraná (UFPR), Brasil. \\ Informações \\ Resumo
}

Recebido 25 Março 2020

Manuscrito revisado recebido

14 Maio 2020

Aceito 19 Maio 2020

$\mathrm{Na}$ atualidade não existe uma metodologia consolidada que permita determinar os consumos de materiais para obter as propriedades mecânicas e hidráulicas do concreto permeável, isso limita a aplicação deste concreto em obras civis. Além disso, as metodologias mais utilizadas para a dosagem de concreto permeável são fundamentas no teste e repetição de experimentos. O objetivo deste artigo é contribuir no desenvolvimento de uma metodologia de dosagem simples, versátil e baseada no desempenho (propriedades finais) do concreto permeável. Para isso foi realizado um programa experimental focado em estudar a influência do volume da pasta nas propriedades finais (porosidade, densidade, velocidade de pulso ultrassônico, permeabilidade e resistência à compressão) do concreto permeável. Os resultados apresentaram diferenças estatisticamente significativas em todas as propriedades finais, exceto a velocidade de pulso ultrassônico, entre as composições com diferentes volumes de pasta. O estudo confirma a possibilidade de uso de uma metodologia experimental simples para dosar concretos permeáveis.

\section{Contribution to the development of design method for pervious concrete based on performance}

\section{Article info}

Received 25 March 2020

Received in revised form 14 May 2020

Accepted 19 May 2020

Keywords

Pervious concrete

Design method

Paste volume

Performance

\begin{abstract}
Currently, there is no consolidated methodology that allows the determination of material consumption to obtain the mechanical and hydraulic properties of pervious concrete, which limits the application of this concrete in civil construction. In addition, the most used methodologies for designing pervious concrete are based on testing and repetition of experiments. The purpose of this paper is to contribute to the development of a simple, versatile design method based on the performance (final properties) of pervious concrete. To do so, an experimental program was carried out focusing on studying the influence of the paste volume on the final properties (porosity, density, ultrasound propagation velocity, permeability and compressive strength) of pervious concrete. The results showed statistically significant differences in all final properties, except the ultrasound propagation velocity, among compositions with different paste volumes. The study confirms the possibility of using a simple experimental methodology to design pervious concrete.
\end{abstract}

\section{Contribución al desarrollo de una metodología de dosificación para hormigón permeable basada en el disempeño}

\section{Información}

Recibido 25 Marzo 2020

Manuscrito revisado recibido

14 Mayo 2020

Aceptado 19 Mayo 2020

Palabras clave

Concreto permeable

Método de dosificación

Volumen de pasta

Desempeño

\section{Resumen}

Actualmente, no existe una metodología consolidada que permita determinar el consumo de materiales para obtener las propiedades mecánicas e hidráulicas del concreto permeable, lo que limita la aplicación de este tipo de concreto en las obras civiles. Además, las metodologías más utilizadas para la dosificación de concretos permeables están fundamentadas en el ensayo y repetición de experimentos. El propósito de este artículo es contribuir al desarrollo de una metodología de dosificación sencilla y versátil basada en el comportamiento (propiedades finales) del concreto permeable. Para ello, se llevó a cabo un programa experimental enfocado a estudiar la influencia del volumen de la pasta en las propiedades finales (porosidad, densidad, velocidad de pulso ultrasónico, permeabilidad y resistencia a la compresión) del concreto permeable. Los resultados mostraron diferencias estadísticamente significativas en todas las propiedades finales, excepto la velocidad del pulso ultrasónico, entre dosificaciones con diferentes volúmenes de pasta. El estudio confirma la posibilidad de utilizar una metodología experimental sencilla para dosificar el concreto permeable.

\footnotetext{
* Autor correspondente em: Centro de Estudos em Engenharia Civil (CESEC), PPG em Engenharia da Construção Civil (PPGECC), UFPR, Brasil.

E-mail: ricpieralisi@ufpr.br (R. Pieralisi)
}

https://doi.org/10.47842/juts.v3i1.19

ISSN: 2675-780X 


\section{Introdução}

O concreto permeável pode ser definido como um tipo especial de concreto utilizado em pavimentos. Em que, a relação entre os materiais constituintes e o nível de compactação devem ser definidos para gerar uma estrutura de poros conectados (PIERALISI et al., 2016; DEBNATH e SARKAR, 2018; XIE et al., 2018). Neste tipo especial de concreto, os teores dos materiais constituintes encontrados na literatura variam em função da aplicação final (NGUYEN et al., 2014; HASELBACH et al., 2018), sendo que convergem para: um teor de agregado miúdo nulo ou baixo (0 - 300 $\mathrm{kg} / \mathrm{m}^{3}$ ); uso de agregados graúdos uniformes; relação água/cimento (a/c) entre 0,28 e 0,40. Essa composição conduz a um concreto permeável com elevada porosidade (10 - $35 \%$ ), com característica seca (slump 0) e densidade no estado endurecido entre $1600 \mathrm{~kg} / \mathrm{m}^{3}$ e $2100 \mathrm{~kg} / \mathrm{m}^{3}$ (CHANDRAPPA e BILIGIRI, 2016a; ZHONG et al., 2018).

A estrutura de poros conectados possibilita a captação de águas pluviais e, se devidamente associados a sistemas de drenagem, transporte para o subleito. Isto porque, o concreto permeável tem como principal propriedade a sua elevada permeabilidade (devendo ser maior que $1 \mathrm{~mm} / \mathrm{s}$ segundo a NBR 16416, 2015) como consequência do seu alto teor de vazios internos interconectados.

Apesar da ACl 522R-10 propor uma metodologia experimental baseada em teste-e-erro para dosar o concreto permeável, é comum encontrar na literatura estudos que partam de uma relação fixa entre materiais e a posterior avaliação das suas propriedades. Isso acontece porque não existe uma metodologia simples, versátil e orientada ao desempenho para dosar este tipo de concreto. Este fato tem limitado a utiização do concreto permeável no meio técnico devido à dificuldade em prever as propriedades mecânicas e hidráulicas sem ter uma noção clara dos consumos de materiais (ZHONG et al., 2018).

Algumas pesquisas (NGUYEN et al., 2014; ZHANG et al., 2020; WANG et al., 2020; XIE et al., 2020) propuseram metodologias de dosagem para facilitar/orientar a estimação do consumo de materiais em função das propriedades requeridas.
Na Tabela 1, estão os principais trabalhos que têm estudado a dosagem do concreto permeável.

Como mostrado na Tabela 1, as metodologias de dosagem ainda estão em fase de desenvolvimento. Um ponto em comum é que todas focam na obtenção da quantidade de pasta necessária para recobrir os agregados e proporcionar as propriedades requeridas em projeto. Apesar dos avanços e boas estimativas das propriedades finais do concreto permeável, a maioria desses métodos são baseados em modelos de reconstrução ou no uso de técnicas complicadas. Esses pontos dificultam o emprego dessas metodologias em centrais de dosagem de concreto.

Nesse sentido, o objetivo deste artigo é contribuir no desenvolvimento de uma metodologia de dosagemsimples, versátil e baseada no desempenho (propriedades finais) do concreto permeável. Para isso foram comparadas as propriedades finais (porosidade, densidade, velocidade de pulso ultrassônico, permeabilidade e resistência à compressão) de 3 composições (variando o volume de pasta) de concreto permeável.

\section{Materiais e Métodos}

\subsection{Propriedade dos materiais}

Cimento Portland Brasileiro CP V ARI foi utilizado na produção do concreto permeável. Foi utilizado agregado graúdo de origem basáltica, sendo peneirando para garantir que suas dimensões variassem entre 2,36 e 9,5 mm. A massa específica e absorção do agregado peneirado foram 2,64 g/ $\mathrm{cm}^{3}$ e $0,27 \%$, respectivamente.

As três composições utilizadas neste estudo estão na Tabela 2. A principal variável relacionada à composição dos concretos permeáveis analisada foi a relação entre agregado e cimento $(\mathrm{Ag} / \mathrm{C})$ em massa, que variou de 2,79 até 3,53. A relação água/ cimento (a/c) foi obtida para a composição T038 utilizando a metodologia proposta por Nguyen et al. (2014) e mantida constante para as outras misturas. Isso conduziu para relações entre pasta (cimento + água) e agregado ( $\mathrm{Pa} / \mathrm{Ag}$ ) em massa 
Tabela 1. Métodos de dosagem encontrados na literatura.

Este método baseia-se na quantificação da camada de pasta de cimento que reveste o agregado a partir dos

NGUYEN et

al. (2014)

grãos dos agregados. Este método de dosagem é dividido em três etapas: determinação do volume de agregado graúdo; determinação do volume da pasta de cimento; e determinação da relação água/cimento.

Este trabalho propôs a otimização da mistura de concreto utilizando o modelo estatístico de metodologia de superfície de resposta (MSR). Com isso foi estabelecida a relação entre as variáveis de mistura e a trabalhabilidade do concreto permeável. A MSR foi usada para dosar a proporção dos materiais do concreto permeável usando ZHANG et agregado reciclado. Do ponto de vista da estrutura interna do concreto permeável, foi identificado que os fatores

al. (2020) que afetam sua resistência e porosidade são as propriedades da pasta, a espessura do revestimento da pasta na superfície do agregado e o conteúdo de vazios do agregado. A espessura ideal da pasta, a espessura real do revestimento e o conteúdo vazio são quantificados e otimizados por meio da MSR para encontrar uma curva granulométrica e uma proporção entre materiais.

Este estudo apresenta um método que visa estimar a mesoestrutura do concreto permeável baseado em técnicas de processamento de imagens usando arquivos de tomografia computadorizada. Uma vez que a mesoestrutura foi

WANG et al. reconstruída, as propriedades no estado endurecido (permeabilidade e resistência à compressão) foram estimadas

(2020) a partir de modelos empíricos que consideram a porosidade total, a espessura média de pasta e a dimensão média dos agregados. Caso as propriedades forem inferiores das requeridas em projeto, os parâmetros de entrada (espessura de pasta, resistência à compressão da pasta, e propriedade dos agregados) são revistos.

Este método consiste na caracterização da estrutura dos vazios internos do concreto permeável a partir do número

Xie et al de contatos entre agregados, da largura dos contatos e da espessura da pasta entre agregados. As estruturas

(2020) dos vazios de diferentes composições foram correlacionadas com suas respectivas propriedades mecânicas e hidráulicas. A partir das correlações, foram propostas equações empíricas. As equações empíricas foram utilizadas na proposta de um método de dosagem baseado em propriedades requeridas. de 0,38 até 0,48. Segundo Pieralisi et al. (2017), a porosidade e a permeabilidade aumentam com a redução da relação $\mathrm{Pa} / \mathrm{Ag}$.

O processo de mistura foi realizado de acordo com a ASTM C192M para todas as composições. Após o processo de mistura, o concreto em estado fresco foi lançando em moldes cilíndricos (com diâmetro de 100 mm e altura de 200 mm), em três camadas. Cada camada foi compactada com 9 golpes do soquete Proctor (equivalente a uma energia de compactação de $128,53 \mathrm{~kJ} / \mathrm{m}^{3}$ ). Foram produzidas 8 amostras para cada composição, totalizando 24 corpos de prova. Após a compactação, os moldes foram colocados em câmara úmida por um período de 24 horas. Depois, cada corpo de prova foi desmoldado e embrulhando em uma sacola plástica com água em seu interior por um período de 28 dias para garantir boas condições de cura.

Tabela 2. Composições dos concretos permeáveis.

\begin{tabular}{cccccc}
\hline $\begin{array}{c}\text { Identifi- } \\
\text { cação }\end{array}$ & $\begin{array}{c}\text { Agregado } \\
\left(\mathbf{k g} / \mathbf{m}^{\mathbf{3}}\right)\end{array}$ & $\begin{array}{c}\text { Cimento } \\
\left(\mathbf{k g} / \mathbf{m}^{\mathbf{3}}\right)\end{array}$ & $\mathbf{A g} / \mathbf{c}$ & $\mathbf{a} / \mathbf{c}$ & $\mathbf{P a} / \mathbf{A g}$ \\
\hline T038 & 1347,97 & 382,26 & 3,53 & 0,34 & 0,38 \\
\hline T043 & 1349,12 & 432,92 & 3,12 & 0,34 & 0,43 \\
\hline T048 & 1353,89 & 484,97 & 2,79 & 0,34 & 0,48 \\
\hline
\end{tabular}

\subsection{Métodos}

Conforme o cronograma de ensaios ilustrado na Figura 1, todos os corpos de prova tiveram as seguintes propriedades determinadas: porosidade e densidade no estado endurecido; velocidade de pulso ultrassônico; permeabilidade; e resistência à compressão. Aos 7 dias de cura, os corpos de prova foram removidos da cura e deixados em estufa com temperatura de $(38 \pm 3){ }^{\circ} \mathrm{C}$ até constância de massa $\left(M_{\text {seco }}\right.$ - massa em estado seco), como previsto pela ASTM C1754. Na sequência, os corpos de prova foram submersos em água $\left(25 \pm 1{ }^{\circ} \mathrm{C}\right.$ ) por $(30 \pm 5)$ min e os procedimentos de choque

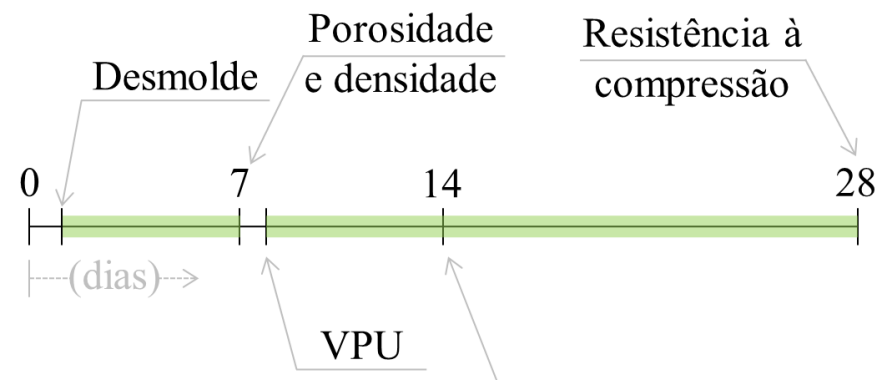

Permeabilidade

\section{Cura}

Fig. 1. Cronograma de realização dos ensaios. 
mecânico indicados pela ASTM C1754 foram realizados até constância de massa $\left(M_{\text {sat }}\right.$ - massa em estado saturado). A porosidade total (P) e a densidade (D) foram calculadas segundo as Eq. (1) e Eq. (2), respectivamente. Nessas equações: $\rho_{w}$ representa a densidade da água $(25 \pm 1){ }^{\circ} \mathrm{C} ; r$ e $L$ representam o raio e a altura do corpo de prova cilíndrico, respectivamente.

$$
\begin{aligned}
& P=\left[1-\frac{\left(M_{\text {seco }}-M_{\text {sat }}\right)}{\rho_{w} \cdot \pi \cdot r^{2} \cdot L}\right] 100 \\
& D=\frac{M_{\text {seco }}}{\pi \cdot r^{2} \cdot L}
\end{aligned}
$$

Após as medições de porosidade e densidade, a velocidade de pulso ultrassônico (VPU) foi calculada (Eq. 3) a partir da medida do tempo de percurso da onda ultrassônica $\left(T_{u}\right)$, que foi realizada com um equipamento de ultrassom da marca PROCEQ/ Pundit Lab seguindo as diretrizes da ASTM C597 e as recomendações de Chandrappa e Biligiri (2016b) e Martins Filho et al. (2020). O Tu foi medido pela transmissão direta na direção longitudinal (altura - L) do corpo de prova. O equipamento foi configurado com frequência de vibração da onda ultrassônica de $24 \mathrm{kHz}$ e com um ajuste no fator de amplificação do receptor de 500 (correspondente a $54 \mathrm{~dB})$.

$$
V P U=\frac{L}{T_{u}}
$$

Aos de 14 dias de cura, todos as amostras foram caracterizadas quanto a sua permeabilidade. Destaca-se que o ensaio de permeabilidade realizado durante esse programa experimental não segue nenhuma normativa específica, e que a comunidade técnico-científica aceita duas configurações de permeâmetros: carga constante (SANDOVAL et al., 2020; WANG et al., 2020); e carga varável (ZHANG et al, 2020; DEBNATH; SARKAR, 2020). Segundo Sandoval et al. (2017), concretos permeáveis ensaiados em permeâmetros de carga constante apresentam coeficientes de permeabilidades superiores aos valores obtidos em permeâmetros de carga variável. Além disso, o coeficiente de variação dos resultados obtidos pelo permeâmetro de carga constante é menor. Desta forma, neste estudo foi utilizado um permâmetro de carga constate com altura de carga igual a 20 cm (correspondente a um gradiente hidráulico - i - igual a 2). O procedimento de ensaio adotado foi o mesmo apresentado por Pieralisi et al. (2017), consistindo em medir a vazão (Q) que passa pelo corpo de prova em um intervalo de tempo de 60 segundos. O coeficiente de permeabilidade (K) foi calculado utilizando a Eq. 4.

$$
K=\frac{Q \cdot i}{\pi \cdot r^{2}}
$$

Ao término do período de cura (28 dias), os corpos de prova foram submetidos ao ensaio de compressão uniaxial de acordo com a norma ABNT NBR 5739 (2018). Todas as amostras foram mantidas em cura entre os dias dos ensaios.

\section{Resultados e Discussões}

\subsection{Resultados}

Na Tabela 3 podem ser observados as médias e desvios padrão (entre parênteses abaixo da média) de todas as propriedades ensaiadas: porosidade; densidade; VPU; permeabilidade; e resistência à

Tabela 3. Propriedades dos concretos permeáveis.

\begin{tabular}{cccccc}
\hline Identificação & Porosidade (\%) & Densidade $\left(\mathbf{k g} / \mathbf{m}^{\mathbf{3}}\right)$ & VPU (m/s) & $\begin{array}{c}\text { Permeabilidade } \\
\text { (mm/s) }\end{array}$ & $\begin{array}{c}\text { Resistência à } \\
\text { compressão (MPa) }\end{array}$ \\
\hline T038 & $24,48(1,20)$ & $1860,21(21,11)$ & $3920,67(28,42)$ & $4,18(0,61)$ & $8,16(0,45)$ \\
\hline T043 & $20,47(1.52)$ & $1929,24(25,38)$ & $4056,92(53,58)$ & $3,01(0,16)$ & $9,58(0,45)$ \\
\hline T048 & $15,91(3,62)$ & $2004,32(60,66)$ & $4070,33(156,33)$ & $1,67(0,32)$ & $11,34(1,06)$ \\
\hline
\end{tabular}



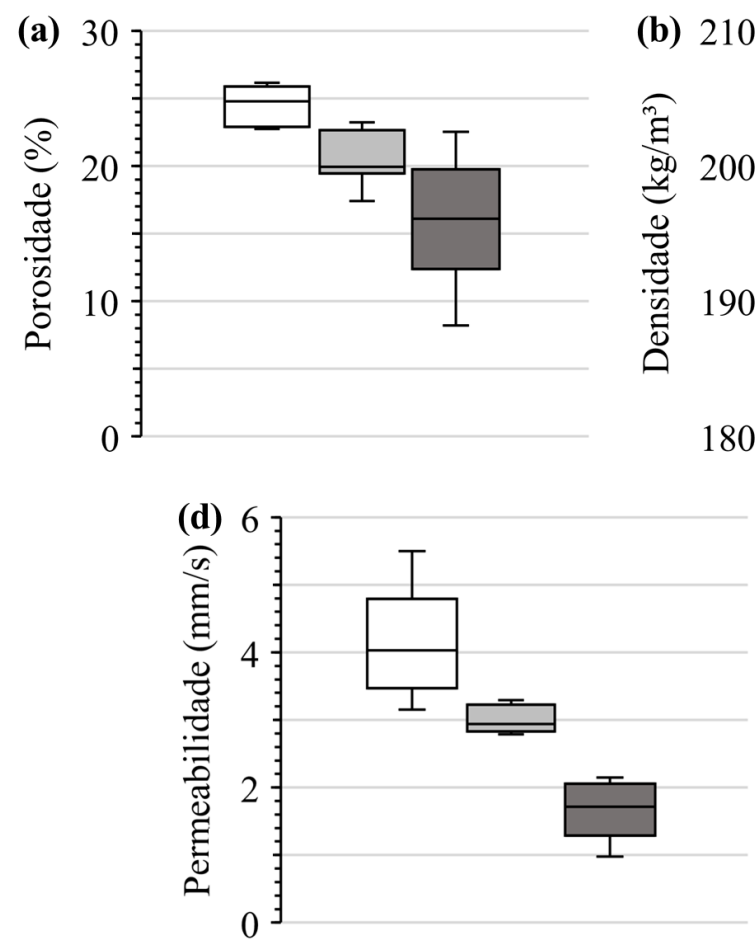
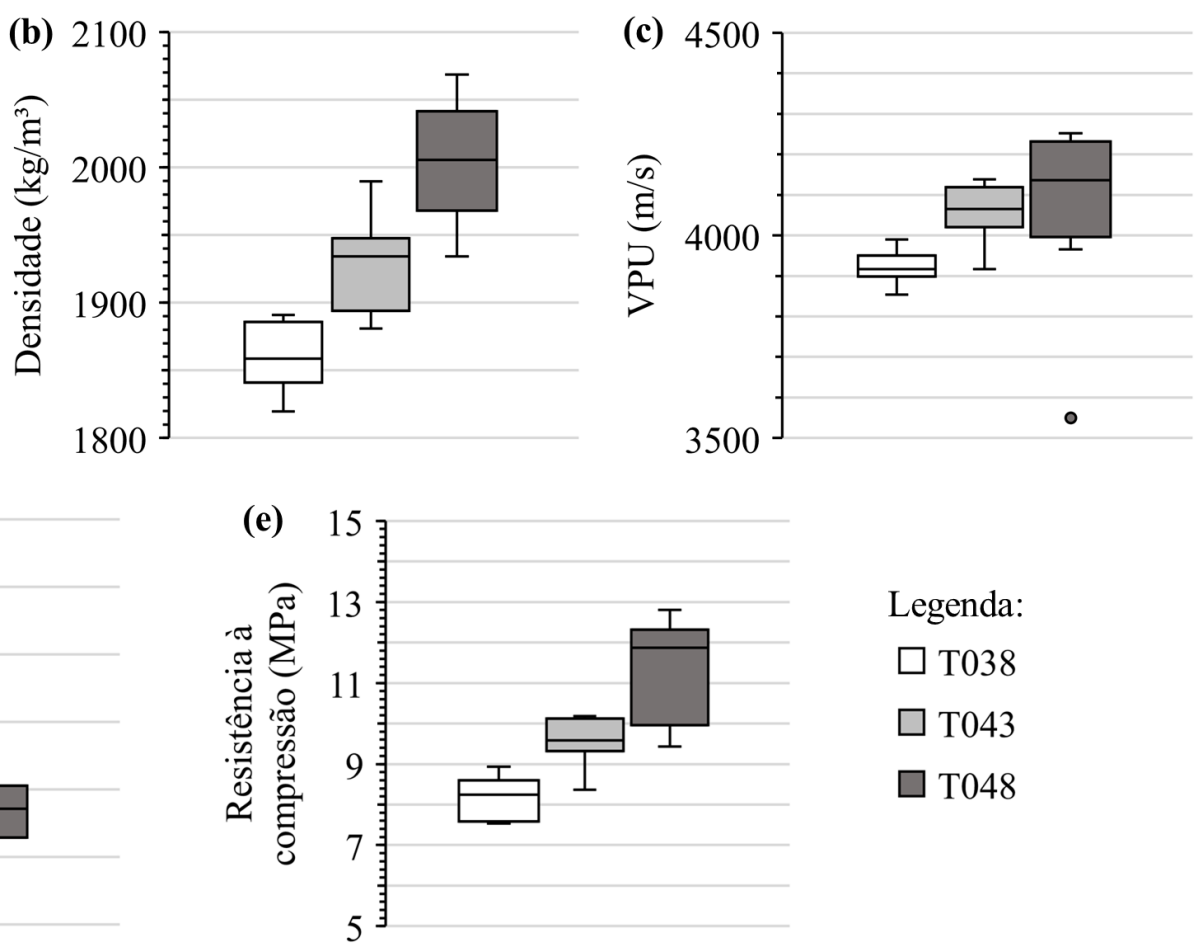

Fig. 2. Box-plot dos resultados de porosidade (a), densidade (b), VPU (c), permeabilidade (d) e resistência à compressão (e).

compressão. Foram realizados ANOVA e teste de Tukey para avaliar se a diferença dos resultados de cada propriedade foi estatisticamente significativa entre as três composições (ver Figura 2). Como pode ser observado na Figura 2a, o acréscimo no consumo de pasta gerou uma redução na porosidade total ( $p$-valor $\leq 0,00017$ em todas as comparações ANOVA e p-valor $\leq$ 0,017 em todas as comparações múltiplas no teste de Tukey). Como esperado, as misturas com maior volume de pasta (maior relação $\mathrm{Pa} / \mathrm{Ag}$ ) apresentaram maior porosidade. Entretanto, elas também apresentaram maior desvio padrão. A hipótese levantada é de que composições com maior quantidade de pasta conduzem a mais possibilidades que a estrutura porosa pode assumir, gerando maior variabilidade na porosidade. Por outro lado (ver Figura 2b), a densidade apresentou-se diretamente proporcional com a alteração no volume de pasta (p-valor $\leq$ 0,00019 em todas as comparações ANOVA e p-valor $\leq$ 0,037 em todas as comparações múltiplas no teste de Tukey).

A velocidade de pulso ultrassônico (VPU) não apresentou diferença estatisticamente significativa entre nenhuma das composições segundo o teste de Tukey (múltiplas comparações), como pode ser observado na Figura 2c. Isso pode estar relacionado com a variação do volume de pasta não ter sido suficiente para ultrapassar o erro associado a sensibilidade do equipamento e a realização do ensaio. Outro ponto importante que dificulta a análise do concreto permeável com ultrassom é a heterogeneidade intrínseca do material. Nesse sentido, os resultados de VPU não serão utilizados na sequência do trabalho.

Como pode ser observado na Figura $2 d$, a permeabilidade, assim como a porosidade, reduziu com aumento da relação $\mathrm{Pa} / \mathrm{Ag}$ ( $\mathrm{p}$-valor $\leq 4,40 \mathrm{E}-$ 6 em todas as comparações ANOVA e p-valor $\leq$ 0,00059 em todas as comparações múltiplas no teste de Tukey). No entanto, a composição T038 (com menor volume de pasta) apresentou o maior desvio padrão, oposto do comportamento apresentado pela porosidade. Isso indica que a permeabilidade não está ligada somente a porosidade. Como observado por Pieralisi et al. (2017), a velocidade do fluxo de água é diretamente dependente do tamanho e conectividade dos poros. Por tanto, a permeabilidade depende tanto da porosidade quanto da tortuosidade (parâmetro que associa o tamanho e conectividade dos poros). No entanto, a tortuosidade é um parâmetro complexo de ser obtido experimentalmente (PIERALISI et al., 2017).

Por último (Figura 2e), a resistência à compressão 


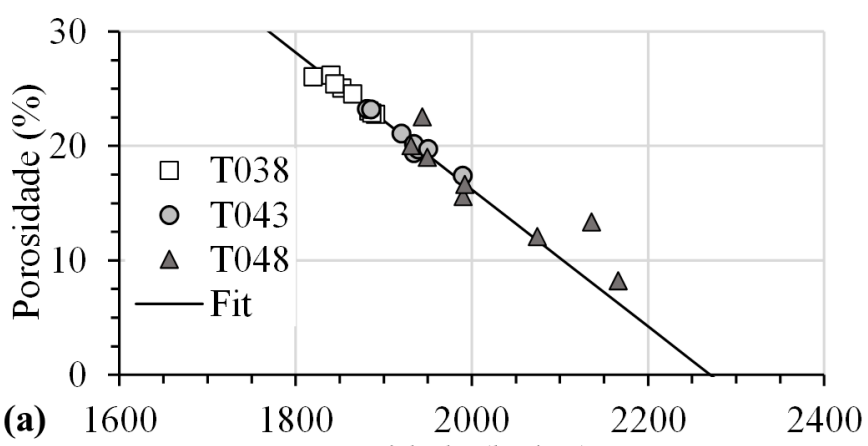

Densidade $\left(\mathrm{kg} / \mathrm{m}^{3}\right)$

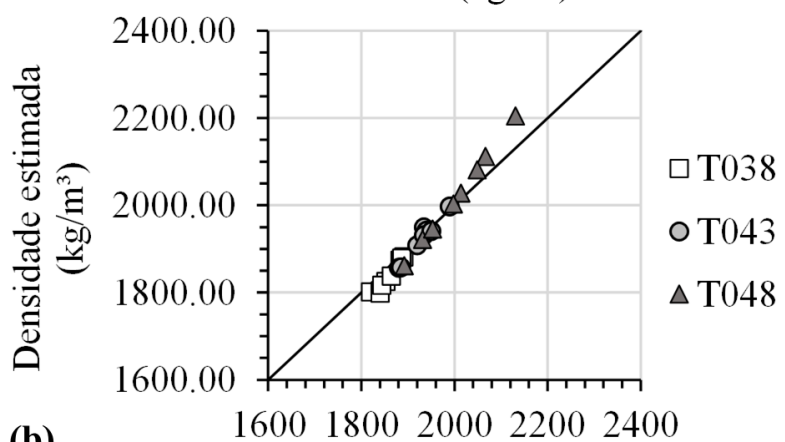

(b)

Densidade experimental $\left(\mathrm{kg} / \mathrm{m}^{3}\right)$

Fig. 3. Relação entre densidade e porosidade (a) e comparação entre densidade experimental e estimada (b).

aumentou com o aumento da relação $\mathrm{Pa} / \mathrm{Ag}$ ( $\mathrm{p}$-valor $\leq 2,71 \mathrm{E}-5$ em todas as comparações ANOVA e p-valor $\leq$ 0,0094 em todas as comparações múltiplas no teste de Tukey). O aumento do volume de pasta conduz à um incremento na ponte de união entre os agregados, distribuindo a tensão em uma área maior e evitando o efeito de resistência de ponta.

\subsection{Correlações entre propriedades}

A partir dos dados obtidos, algumas correlações podem ser realizadas com o objetivo de entender o comportamento do concreto permeável quando o volume de pasta (relação $\mathrm{Pa} / \mathrm{Ag}$ ) é alterado. Como mostrado na Figura 3a, existe uma correlação linear muito forte (acurácia de 0,696 \% e precisão de $0,747 \%$ ) entre densidade e porosidade. Esse nível de correlação era esperado, uma vez que a granulometria e a mineralogia dos agregados, e a relação a/c não foram alteradas. O consumo real médio de cimento (c - já apresentado na Tabela 2) deve ser calculado com o resultado experimental de porosidade média ( $P$ - Tabela 3) e pela Eq. 5. Nessas equações: $\rho_{c^{\prime}} \rho_{a g}$ e $\rho_{a}$ representam as densidades do cimento, do agregado e da água, respectivamente. A comparação entre a densidade experimental e a densidade estimada (derivada a
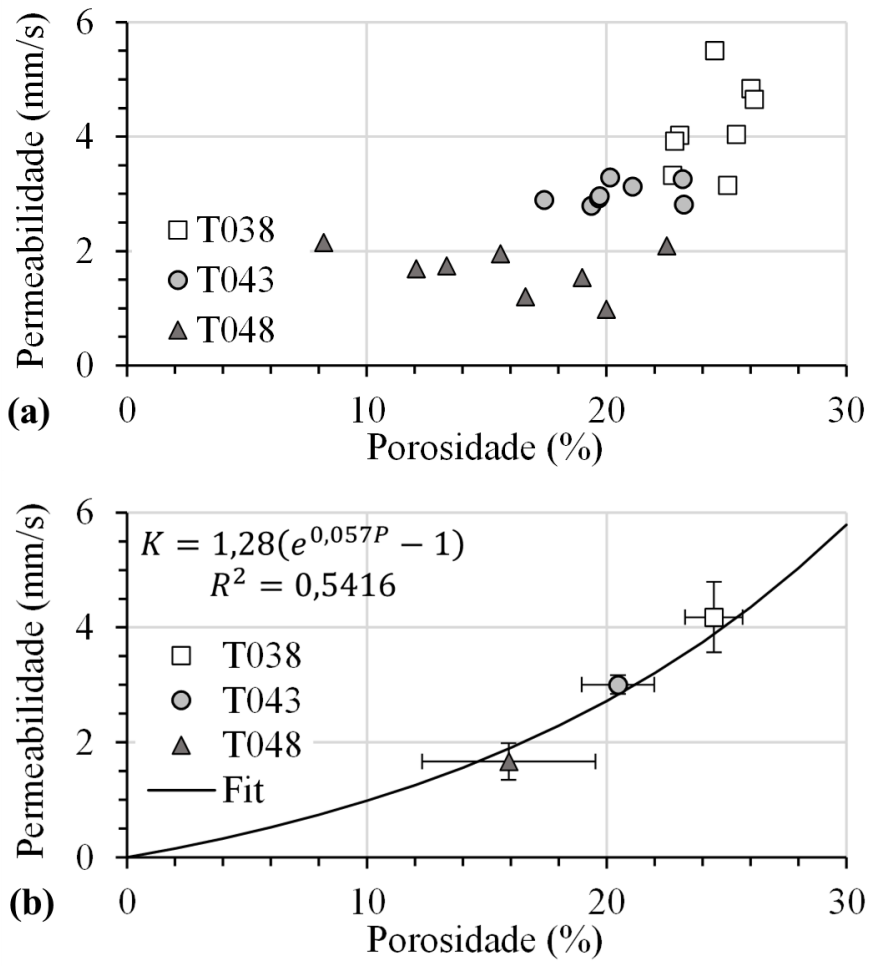

Fig. 4. Relação entre porosidade e permeabilidade.

partir da Eq. 5) do concreto permeável pode ser observada na Figura 3b.

$c=\frac{1-\bar{P}}{\left(\frac{1}{\rho_{c}}+\frac{A g / c}{\rho_{a g}}+\frac{a / c}{\rho_{a}}\right)}$

A relação entre porosidade e permeabilidade (ver Figura 4a) apresentou uma correlação moderada (acurácia igual a 0,609 mm/s e precisão igual a 0,385 mm/s), evidenciando que a permeabilidade não depende unicamente da porosidade. Dentre as equações empíricas utilizadas com frequência na literatura para correlacionar a porosidade com a permeabilidade, destacam-se: exponencial (SONEBIA et al., 2016; CHANDRAPPA e BILIGIRI, 2016a; SANDOVAL et al., 2017; SANDOVAL et al., 2019); e exponencial natural (MAGUESVARI e NARASIMHA, 2013; ZAETANG et al., 2016; PIERALISI et al., 2017). Neste trabalho, optou-se pela utilização da função exponencial natural modificada (Eq. 6). Esta equação tem a característica de apresentar a permeabilidade $(K)$ tendendo a $\mathrm{O}$ quando a porosidade $(\mathrm{P})$ tende a $\mathrm{O}$, comportamento esperado 

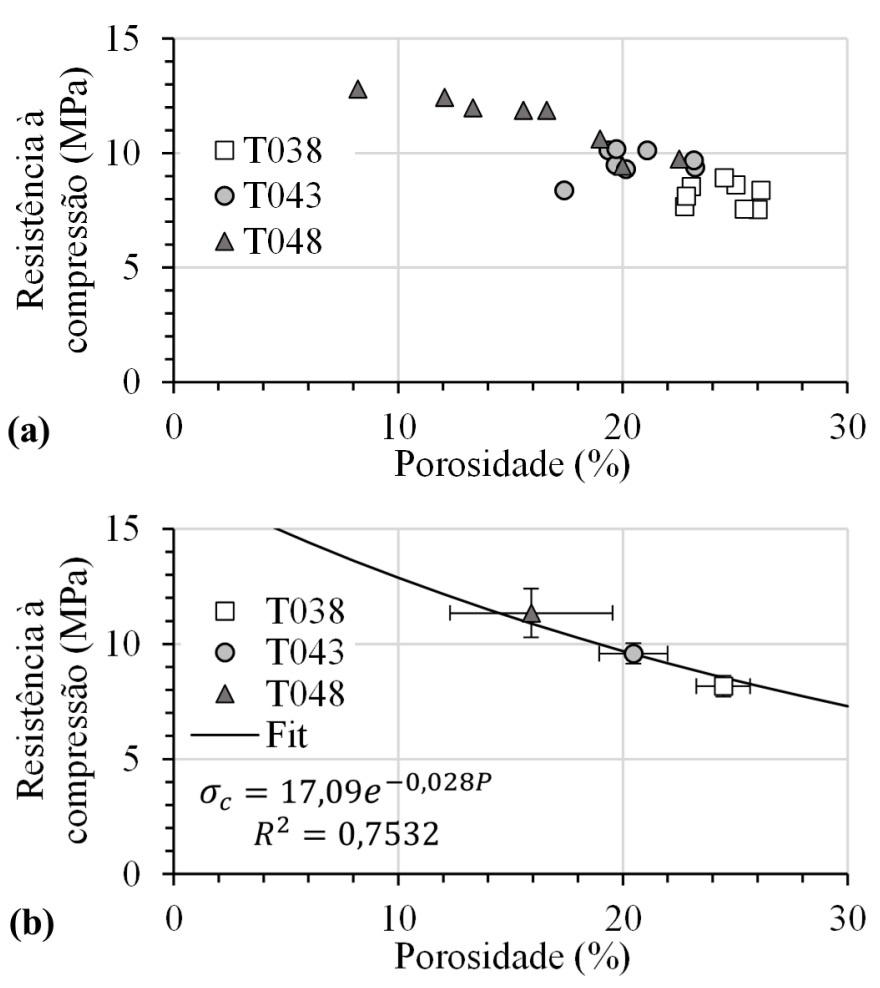

Fig. 5. Relação entre porosidade e resistência à compressão

para o concreto permeável. Na Figura 4b pode-se observar as médias e desvio padrão dos resultados experimentais e a plotagem da equação empírica ajustada pelo método dos mínimos quadrados.

$$
K=1,28\left(e^{0,057 \cdot P}-1\right)
$$

A relação entre porosidade $(P)$ e resistência à compressão $\left(\sigma_{c}\right)$ para todas as amostras está apresentada na Figura 5a. A equação exponencial natural (Eq. 7) foi ajustada pelo método dos mínimos quadrado (apresentando uma acurácia de 0,632 MPa e uma precisão de 0,311 MPa) como modelo empírico para correlacionar essas duas propriedades (ver Figura 5b).

$$
\sigma_{c}=17,09 e^{-0,028 \cdot P}
$$

2014; ZHANG et al., 2020; WANG et al., 2020; XIE et al., 2020) de metodologias de dosagem para concreto permeável disponíveis na literatura. Sendo que a metodologia empírica apresentada pela $\mathrm{ACl}$ 522R-10 é mais utilizada atualmente.

A proposta metodológica apresentada neste artigo está baseada no Método IBRACON (ISAIA, 2011) para dosagem de concretos convencionais. O Método IBRACON (ISAIA, 2011) trabalha com modelos clássicos do concreto. No entanto, o modelo de Abrams não pode ser aplicado de forma direta em concretos não plásticos, como no caso do concreto permeável. Uma demonstração sobre a não aplicabilidade do modelo de Abrams foi apresentada no trabalho de Sonebi e Bassuoni (2013), que confirmou que o aumento da relação a/c conduz no aumento da resistência à compressão.

Desta forma, propõe-se a montagem de um diagrama de desempenho (ver Figura 6) como proposta metodológica para a dosagem do concreto permeável. Esse diagrama busca relacionar a razão entre materiais (sendo que este artigo está limitado no estudo da relação $\mathrm{Pa} / \mathrm{Ag}$ ) com as principais propriedades no estado endurecido (porosidade, permeabilidade e resistência à compressão). O ábaco foi construído pela: relação entre $\mathrm{Pa} / \mathrm{Ag}$ e porosidade realizada pelo ajuste de uma equação linear (Eq. 8 - acurácia de 2,09 \% e precisão 1,48 \% ao considerar todos as amostras; acurácia de 0,12 \% e precisão de 0,04 \% ao realizar a análise com a média dos valores experimentais); relação entre permeabilidade e porosidade feita utilizando a Eq. 6; e relação entre permeabilidade e resistência à compressão feita utilizando a Eq. 6 e a Eq. 7. Com o ábaco construído, pode-se obter a composição otimizada entrando com a permeabilidade ou resistência à compressão requerida em projeto. Sendo que o ábaco pode ser utilizado desde que a propriedade requerida esteja entre os valores mínimo e máximo obtidos experimentalmente a curva extrapolada (em tracejado) não pode ser empregada na dosagem.

$$
P=-85,61(P a / A g)+57,1
$$

Como apresentado anteriormente, existem algumas propostas (ACl 522R-10; NGUYEN et al., 


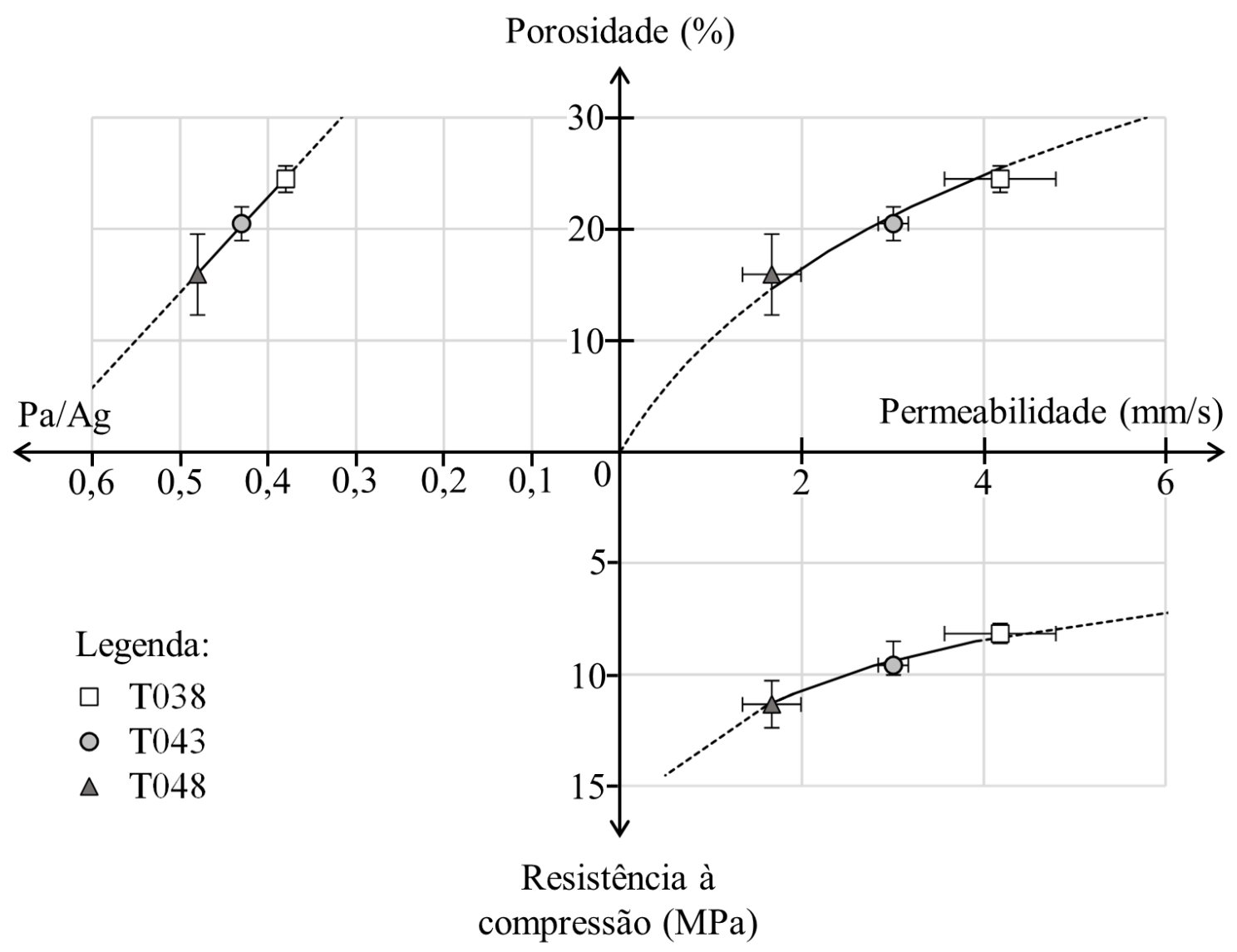

Fig. 6. Diagrama de desempenho.

O fluxograma dos passos necessários para obter a dosagem otimizada segundo uma determinada propriedade (permeabilidade ou resistência à compressão) a partir da metodologia de dosagem baseada no desempenho proposta neste trabalho está na Figura 7. O método inicia com a escolha do agregado e sua granulometria, que normalmente está relacionada com a disponibilidade do material, e da definição da propriedade (permeabilidade ou resistência à compressão) requerida em projeto. Vale ressaltar que o método pode ser estendido para outras propriedades, como: módulo de elasticidade; resistência à tração (na flexão ou indireta); resistência ao desgaste superficial; resistência à abrasão.

Na sequência, no mínimo 3 composições (relação $\mathrm{Ag} / \mathrm{c}$ em massa) precisam ser escolhidas. Este trabalho utilizou o método proposto por Nguyen et al. (2014) para definir a relação a/c. Caso uma análise da relação a/c queira ser feita, 3 relações $\mathrm{Ag} / \mathrm{c}$ deveram ser preparadas para cada relação a/c em estudo. As misturas devem ser preparadas e as propriedades finais devem ser analisadas nas idades correspondentes.
Com todos os dados de composição associado às propriedades finais, o diagrama de desempenho (similar ao apresentado na Figura 6) pode ser construído. Com o diagrama de desempenho construído, a dosagem otimizada em relação à propriedade final requerida pode ser obtida.

\section{Conclusões}

As seguintes conclusões podem ser feitas baseadas nas análises dos resultados:

- Os resultados obtidos indicam que o aumento no volume de pasta (consumo de cimento), sem alterar a relação $a / c$, conduz na redução da porosidade com aumento da variabilidade.

- O consumo real de cimento deve ser corrigido a partir da porosidade média obtida experimentalmente e da relação entre materiais (agregado/cimento e água/cimento).

- Os resultados obtidos pelo método do ultrassom (velocidade de pulso ultrassônico) não apresentaram diferenças estatisticamente significativas entre as composições estudadas, mostrando que o método 
Escolha do tipo e granulometria do agregado graúdo (depende da disponibilidade)

Estabelecer a propriedade (permeabilidade ou resistência à compressão) requerida em projeto

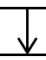

Escolher no mínimo 3 composições (relação $\mathrm{Ag} / \mathrm{c}$ em massa)

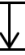

Verificar as propriedades finais (porosidade, permeabilidade e resistência à compressão

Construir o diagrama de desempenho específico para as composições ensaiadas

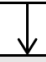

Obter a dosagem otimizada a partir do diagrama de desempenho entrando com a propriedade requerida

Fig. 5. Relação entre porosidade e resistência à compressão

do ultrassom tem restrições quando aplicado em concretos permeáveis.

- A correlação entre os resultados de porosidade e permeabilidade indicou que a permeabilidade não depende unicamente da porosidade, outros fatores como o tamanho e conectividade dos poros podem ser importantes na análise.

- Um ábaco de desempenho pôde ser construído a partir de equações empíricas ajustadas pelos resultados experimentais. Com ele, pode-se obter a composição otimizada entrando com a permeabilidade ou resistência à compressão requerida em projeto.

\section{Agradecimentos}

Os autores agradecem ao Programa de PósGraduação em Engenharia de Construção Civil (PPGECC) e ao Laboratório de Materiais e Estruturas da Universidade Federal do Paraná (UFPR) pelo apoio durante a realização do programa experimental.

\section{Referências bibliográficas}

AMERICAN CONCRETE INSTITUTE. ACI 522R-10, Report on Pervious Concrete. ACI Committee 522, 2010.

AMERICAN SOCIETY FOR TESTING AND MATERIALS. ASTM C597, Pulse velocity through concrete, ASTM International, West Conshohocken, PA, 1989.

AMERICAN SOCIETY FOR TESTING AND MATERIALS. ASTM C1754 / C1754M, Standard Test Method for Density and Void Content of Hardened Pervious Concrete, ASTM International, West Conshohocken, PA, 2012.

AMERICAN SOCIETY FOR TESTING AND MATERIALS. ASTM C192 / C192M, Standard Practice for Making and Curing Concrete Test Specimens in the Laboratory, ASTM International, ASTM International, West Conshohocken, PA, 2018.

ASSOCIAÇÃO BRASILEIRA DE NORMAS TÉCNICAS. ABNT NBR 5739: Concreto - Ensaio de compressão de corpos de prova cilíndricos. Rio de Janeiro: ABNT, 1994.

ASSOCIAÇÃO BRASILEIRA DE NORMAS TÉCNICAS. ABNT NBR 16416: Pavimentos permeáveis de concreto - Requisitos e procedimentos. Rio de Janeiro: ABNT, 2015.

CHANDRAPPA, A. K.; BILIGIRI, K. P. Comprehensive investigation of permeability characteristics of pervious concrete: A hydrodynamic approach. Construction and Building Materials, v. 123, p. 627-637, 2016a.

CHANDRAPPA, A. K.; BILIGIRI, K. P. Influence of mix parameters on pore properties and modulus of pervious concrete: an application of ultrasonic pulse velocity. Materials and Structures, v. 49, p. 5255-5271, 2016b.

DEBNATH, B.; SARKAR, P. P. Pervious concrete 
as an alternative pavement strategy: a state-ofthe-art review. International Journal of Pavement Engineering, International Journal of Pavement Engineering. p. 1-16, 2018.

HASELBACH, L. et al. Best practices for pervious concrete mix design and laboratory tests. IBRACON Structures and Materials Journal, v. 11, p. 1-11, 2018.

ISAIA, G.C. Concreto: Ciência e Tecnologia. 1a ed. São Paulo: IBRACON, 2011.

MAGUESVARI, U. M.; NARASIMHA, V. L. Studies on Characterization of Pervious Concrete for Pavement Applications. Procedia - Social and Behavioral Sciences, v. 104, p. 198-207, 2013.

MARTINS FILHO, S. T. et al. Characterization of pervious concrete focusing on non-destructive testing. IBRACON Structures and Materials Journal, v. 13, n. 3, p. 483-500, 2020.

NGUYEN, D. H. et al. A modified method for the design of pervious concrete mix. Construction and Building Materials, v. 73, p. 271-282, 2014.

PIERALISI, R.; CAVALARO, S.H.P.; AGUADO. A Advanced numerical assessment of the permeability of pervious concrete. Cement and Concrete Research, v. 102, p. 149-160, 2017.

PIERALISI, R.; CAVALARO, S.H.P.; AGUADO. A. Discrete element modelling of the fresh state behavior of pervious concrete. Cement and Concrete Research, v. 90, p. 6-18, 2016.

SANDOVAL, G. F. B. et al. Hydraulic behavior variation of pervious concrete due to clogging. Case Studies in Construction Materials, v. 13, e00354, 2020.

SANDOVAL, G. F. B. et al. Correlation between permeability and porosity for pervious concrete (PC). DYNA, v. 86, n. 209, p. 151-159, 2019.

SANDOVAL, G. F. B. et al. Comparison between the falling head and the constant head permeability tests to assess the permeability coefficient of sustainable Pervious Concretes. Case Studies in Construction Materials, v. 7, p. 317-328, 2017.

SONEBI, M.; BASSUONI, M.; YAHIA, A. Pervious Concrete: Mix Design, Properties and Applicantions. RILEM Technical Letters, v. 1, p. 109-115, 2016.

SONEBI, M.; BASSUONI, M. T. Investigating the effect of mixture design parameters on pervious concrete by statistical modelling. Construction and Building Materials, v. 38, p. 147-154, 2013.

WANG, Z. et al. A novel method to predict the mesostructure and performance of pervious concrete. Construction and Building Materials, v. 263, p. 120117, 2020.

$X I E, X$. et al. Mixture proportion design of pervious concrete based on the relationships between fundamental properties and skeleton structures. Cement and Concrete Composites, v. 113, p. 103693, 2020.

$X I E, X$. et al. Maximum paste coating thickness without voids clogging of pervious concrete and its relationship to the rheological properties of cement paste. Construction and Building Materials, v. 168, p. 732-746, 2018.

ZAETANG, Y. et al. Properties of pervious concrete containing recycled concrete block aggregate and recycled concrete aggregate. Construction and Building Materials, v. 111, p. 15-21, 2016.

ZHANG, Q. et al. Mix design for recycled aggregate pervious concrete based on response surface methodology. Construction and Building Materials, v. 259, 119776, 2020.

ZHONG, R. et al. Research and application of pervious concrete as a sustainable pavement material: A state-of-the-art and state-of-the-practice review. Construction and Building Materials, v. 183, p. 544-553, 2018. 
Publicação organizada pelo Programa de

Mestrado Profissional Stricto Sensu em

Engenharia Civil da Universidade São Judas

Volume 03 - Edição 03

Janeiro - Dezembro de 2020

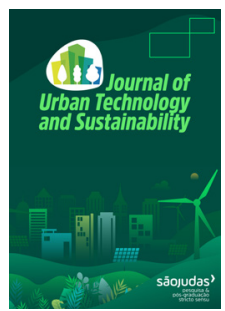

\author{
Characterization of construction and demolition wastes for civil engineering uses \\ João A. Paschoalin Filhoa,", Diego G. Camelob, David de Carvalhoc, António J. G. Dias ${ }^{d}$, Brenno A. M. Versolatto ${ }^{b}$ \\ ${ }^{a}$ Nove de Julho University- Master Degree in Sustainable and Intelligent Cities, Itaci Street, 206, apt 83, São Paulo/Brazil, 02460-030. \\ ${ }^{b}$ Nove de Julho University - Master Degree in Sustainable and Intelligent Cities, São Paulo/Brazil.

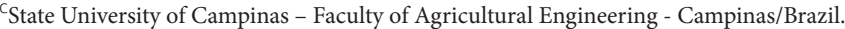 \\ ${ }^{d}$ University of Porto, Portugal - Faculty of Sciences. Department of Geology and Territory - Porto/Portugal.
}

\section{Article info}

Received 14 April 2020

Received in revised form 29

May 2020

Accepted 03 June 2020

\section{Keywords}

Civil construction

Construction and demolition

waste

Recycling

\begin{abstract}
Construction and demolition wastes have been studied by technical means to develop management tools to reduce environmental impacts. Among the methods evaluated, recycling can be highlighted. This article demonstrates the characterization of engineering parameters for concrete construction wastes obtained at a C\&DW recycling plant near São Paulo. To this end, laboratory tests were performed according to relevant technical standards to determine the following characteristics: specific weight, integrity using ultrasound, compressive strength, elasticity modulus, and absorption. The parameters obtained may serve to characterize the waste under study, as well as initial values for the development of basic civil engineering projects with low structural responsibility.
\end{abstract}

\title{
Caracterização de resíduos de construção e demolição para uso em engenharia civil
}

\section{Informações}

Recebido 14 Abril 2020

Manuscrito revisado recebido 29 Maio 2020

Aceito 3 Junho 2020

\section{Palavras-chave}

Construção civil

Resíduos de construção e

demolição

Reciclagem

\section{Resumo}

Resíduos de construção e demolição têm sido estudados por meios técnicos para desenvolver ferramentas de gestão para reduzir os impactos ambientais. Dentre essas, a reciclagem pode ser destacada. Este artigo demonstra a obtenção e avaliação de parâmetros de engenharia para resíduos de construção de concreto obtidos em uma usina de reciclagem de RCD próxima a São Paulo. Para tanto, foram realizados ensaios laboratoriais de acordo com as normas técnicas pertinentes para determinação das seguintes características: peso específico, integridade por ultrassom, resistência à compressão, módulo de elasticidade e absorção. Os parâmetros obtidos podem servir para melhor caracterizar os resíduos em estudo, bem como valores iniciais para o desenvolvimento de projetos básicos de engenharia civil com baixa responsabilidade estrutural.

\section{Caracterización de residuos de construcción y demolición para su uso en ingeniería civil}

\section{Información}

Recibido 14 Abril 2020

Manuscrito revisado recibido 29 Mayo 2020

Aceptado 3 Junio 2020

\section{Palabras clave}

Construcción Civil

Resíduos de construcción y demolición

Reciclaje

\section{Resumen}

Residuos de construcción y demolición han sido estudiados por medios técnicos para desarrollar herramientas de gestión que reduzcan los impactos ambientales. Entre estas, se puede destacar el reciclaje. También es de destacar que el entorno técnico aún no cuenta con una cantidad adecuada de trabajos científicos que presenten el estudio de las características de ingeniería obtenidas para los residuos de la construcción, lo que, muchas veces, imposibilita considerar estos residuos para su uso en ingeniería civil. Así, este artículo demuestra la obtención y evaluación de parámetros de ingeniería para residuos de construcción de hormigón obtenidos en una planta de reciclaje de RCD cerca de São Paulo. Para ello, se realizaron pruebas de laboratorio de acuerdo con las normas técnicas relevantes para determinar las siguientes características: peso específico, integridad mediante ultrasonidos, resistencia a la compresión, módulo de elasticidad y absorción. Los parámetros obtenidos pueden servir para caracterizar mejor el residuo en estudio, así como valores iniciales para el desarrollo de proyectos de ingeniería civil básica con baja responsabilidad estructural.

\footnotetext{
* Corresponding author at: Nove de Julho University- Master Degree in Sustainable and Intelligent Cities, São Paulo/Brazil.

E-mail address: paschoalinfilho@yahoo.com (João A. Paschoalin Filho)
} 


\section{Introduction}

Civil construction consists of an essential industrial sector, responsible for a country's social and economic development, generating direct and indirect jobs. According to Maia and Neto (2016), the construction industry has generated about 7\% of all world jobs in 2015 and reduced housing and infrastructure deficits. According to the Brazilian Institute of Geography and Statistics (IBGE), the civil construction production chain has represented $5.2 \%$ of Brazilian Gross Domestic Product (GDP) in 2016 (IBGE, 2017).

However, despite proportioned benefits, the civil construction sector is responsible for environmental impacts caused by its daily activities, such as noise, air pollution, dust, solid waste generation, natural resources impoverishment (YUAN, 2012; CHEN et al., 2019). According to Esa et al. (2017), 40\% of industrial waste generated in the world comes from the construction industry.

According to Jin et al. (2019), construction and demolition waste management is an interdisciplinary issue that involves environmental, technical, economic, and social aspects. It also covers complicated issues from political, management, and engineering perspectives.

Construction and demolition waste (C\&DW) recycling bring environmental and economic benefits to the cities where it is implemented, considering that, in addition to reducing waste management costs, this favorable economic gain due to the cost of the recycled product being less than the natural aggregate. For Duran et al. (2006), C\&DW becomes economically viable when their landfill dumping cost is higher than the cost of transport to the recycling center, and the cost of using the primary aggregate exceeds the cost of the recycled material.

Facing it, the importance of construction and demolition wastes studies raised due to the scarcity of natural materials and environmental concerns (MENEGAKI; DAMIGOS, 2018). The construction and demolition wastes account for 30 to $40 \%$ of the total mass of produced solid urban waste all over the world (JIN et al., 2018). When improperly managed, this waste causes soil, water, and air pollution (MAHPOUR, 2018).

The quantity and the composition of C\&DW can vary between different regions depending on many factors such as economic growth, legislation, public policy, constructor expertise, type of constructions, regional planning, and others (Menegaki \& Damigos, 2018). It estimated that more than 10 billion tonnes of C\&DW was generated over the world in 2017 (WANG et al., 2019).

In 2016, the European Union generated 923,540,000 tonnes of C\&DW (EUTOSTAT, 2017), in the USA, in 2014, approximately 540 million tonnes were generated (28.9 million tonnes during construction and 511.1 million tonnes during demolition activities). Australia and China in 2014 generated 19.5 million tonnes and 1.13 billion tonnes, respectively (Menegaki \& Damigos, 2018). The United Kingdom, in 2012, generated 200 million tonnes of waste, of which $50 \%$ was produced in Construction and Demolition. Blaisi (2019) informs that in Saudi Arabia in 2016 was generated 131,436 tonnes of C\&DW.

According to Miranda et al. (2009), until 2008, the volume of recycled construction wastes in Brazil was in the range of $4.8 \%$ of the total generated. However, according to Paschoalin Filho et al. (2017), it is estimated that in the country, there is a recycling of up to $21 \%$ of the volume of C\&DW. In Malaysia, this percentage reaches 15\%. In countries like South Korea, Singapore, and Germany, the recycling of C\&DW is in the range of $50 \%$ to $75 \%$ of the total generated, in Australia, this percentage is about 48\% (ESA et al., 2017; TAM et al., 2009).

Environmental, social, and economic advantages of C\&DW recycling in the construction sites have been highlighted by the surveys of Arif et al. (2012); Oyedele et al. (2013); Paschoalin Filho et al. (2017) Tam et al. (2009), among others.

In the last decade (2010-2020), the feasibility and efficient management of C\&DW has been widely studied by many research (PASCHOALIN FILHO et al., 2017). Blaisi (2019) concluded that the critical elements for successful management include (i) awareness of waste management (ii) 
waste management regulations and systems (iii) sustainable building technologies and (iv) C\&DW management plans for construction and demolition work.

According to Paschoalin et al. (2017), the waste generated in a construction site can represent a significant environmental liability, if not adequately managed and destined. In this way, the management of Construction and Demolition Wastes has great importance in ensuring their correct management by adopting techniques in line with sustainability practices.

Nagapan et al. (2012) suggest that the most significant factors causing construction and demolition waste generation are errors in the design and execution phase, inadequate construction planning, poorly skilled labor, and inefficient management of building sites.

\section{Materials and methods}

Concrete waste was collected at a C\&DW Recycling Plant located in São Caetano do Sul / SP. For the execution of the laboratory tests, it was necessary to extract specimens from the concrete waste blocks, which would meet the size recommended in the standard ABNT NBR 12025 (2012).

The procedure for extracting the specimens complied with the criteria stipulated by the standard ABNT NBR NM 7680 (2015). A diamond cup saw was used to extract the specimens, with the following cup dimensions: $50 \mathrm{~mm}$ outside diameter $\times 44 \mathrm{~mm}$ inside diameter $\times 116 \mathrm{~mm}$ height. Figure 1 shows the process of the extraction

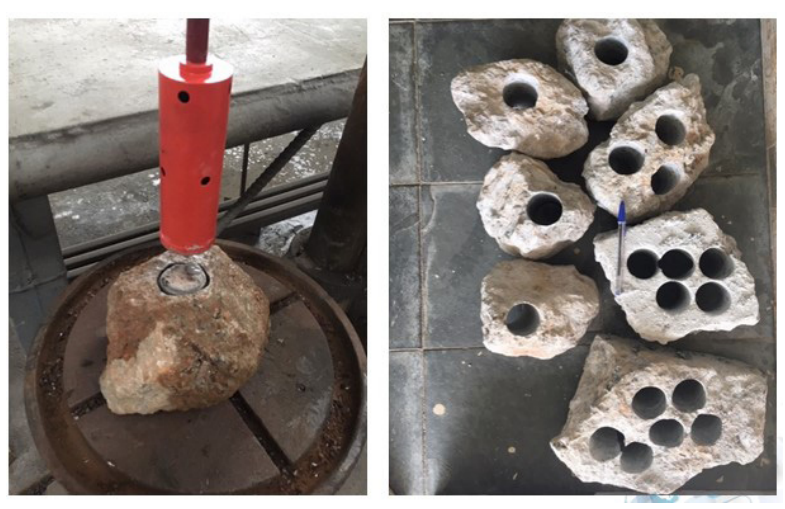

Fig. 1. Extraction of specimens. of the specimen.

A circular Table saw with a 2HP motor, and a 9-inch diamond saw blade was used to homogenize the heights of the extracted specimens, as shown in figure 2. To verify internal fissures existence that could affect the specimen's compressive strength, ultrasound tests were performed according to ABNT NBR 8802 (2010) recommendations. Figure 3 shows an ultrasound test performed for a C\&DW specimen.

Compressive tests were performed to obtain specimen's strength following the procedures given by ABNT NBR NM 8522 (2017). The equipment used was a compression press test equipment, model EMIC GRO48 (300 kN of maximum compressive capacity). Figure 4 and 5 show the specimens prepared for the test and in the process of rupture in the press.

Tests were also performed to determine the Elasticity Modulus of the specimens. This procedure was carried out following the recommendations of ABNT NBR NM 8522 (2017). Figure 6 shows the test in progress.

\section{Results and discussion}

Table 1 presents the physical characteristics of C\&DW specimens. It can be seen that the average diameters obtained for the specimens was 43.84 $\mathrm{mm}$ ( $\mathrm{sd}=0.3 \mathrm{~mm} ; \mathrm{cv}=0.6 \%)$. The average height determined for specimens was $91.54 \mathrm{~mm}$ ( $\mathrm{sd}=$ $1.2 \mathrm{~mm} ; \mathrm{cv}=1.4 \%)$. The average mass obtained was $0.308 \mathrm{~kg}$ ( $\mathrm{sd}=0.01 \mathrm{~kg}, \mathrm{cv}=3.4 \%)$. In terms of average specific weight, the obtained value for $\mathrm{C} \& D W$ was $22.35 \mathrm{kN} / \mathrm{m}^{3}$ ( $\mathrm{sd}=0.8 \mathrm{kN} / \mathrm{m}^{3}, \mathrm{cv}=$ $3.4 \%)$.

In general, all construction waste specimens had specific weights according to ABNT NBR 9778, i.e., between 20 and $28 \mathrm{kN} / \mathrm{m}^{3}$. The average specific weight was $22.35 \mathrm{kN} / \mathrm{m}^{3}$, with standard error equal to $0.25 \mathrm{kN} / \mathrm{m}^{3}$.

Therefore, according to the standard deviation value and coefficient of variation determined, it can be assumed that the dimensions of the specimens presented low variations concerning height and 


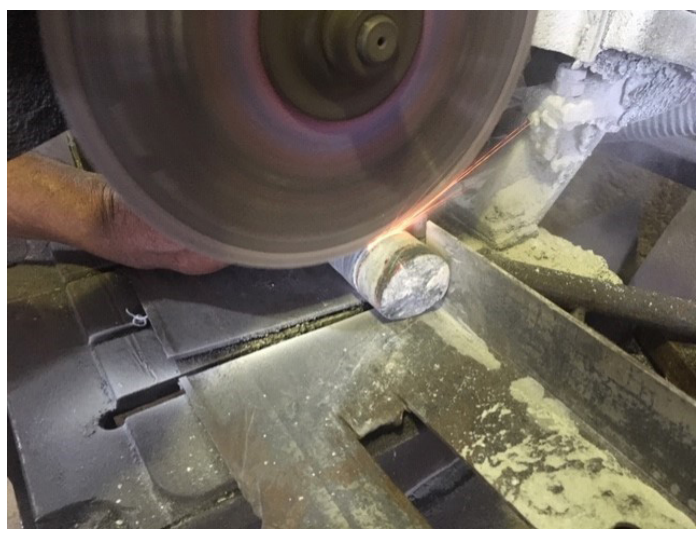

Fig. 2. Homogenization of the heights of the specimens.

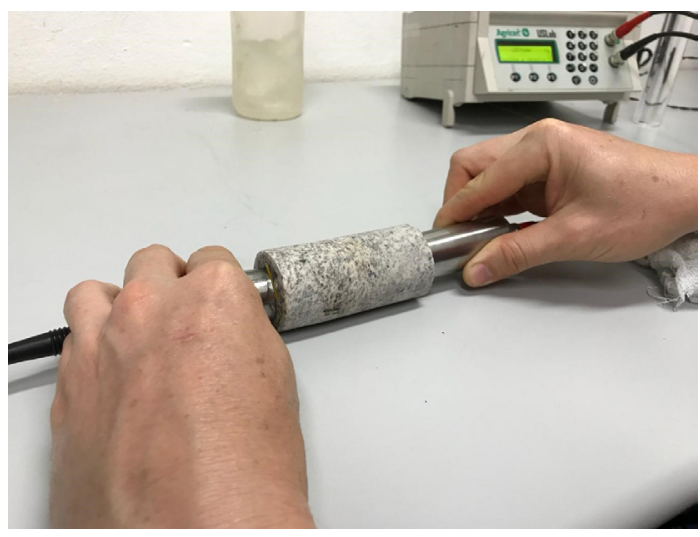

Fig. 3. Ultrasound testing.

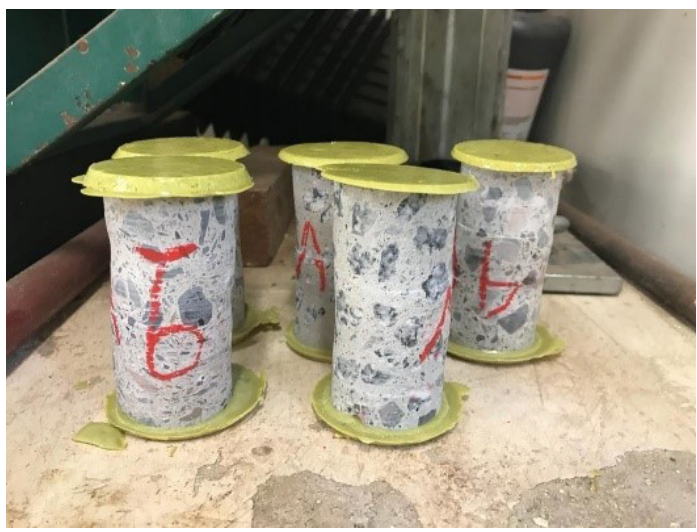

Fig. 4. Capped specimens for compression tests.

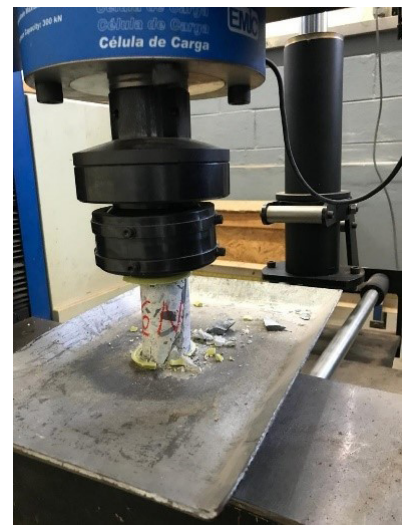

Fig. 5. Rupture of specimens.

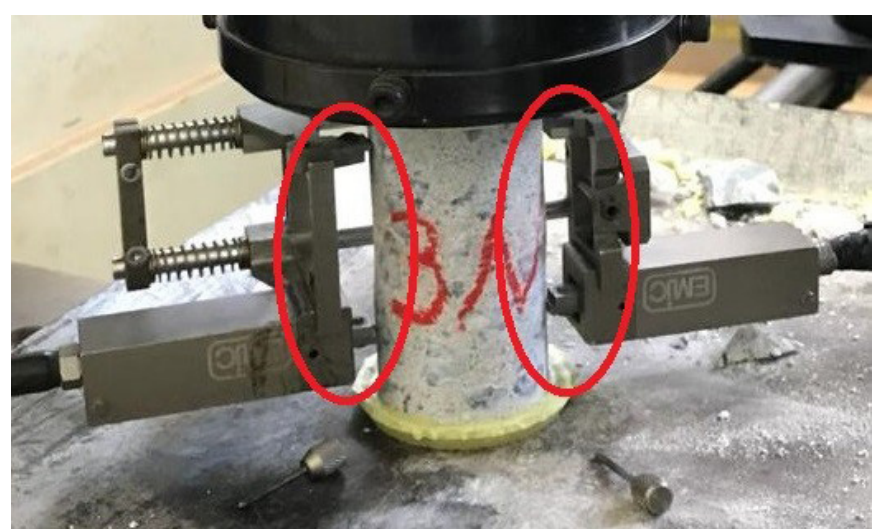

Fig. 6. Modulus of elasticity test.

diameter, which shows that they were satisfactory carved. Besides, the height/diameter ratios are approximately 2.0, which meets the requirements of ABNT NBR 12024 (2010).

Aiming to verify the internal integrity of the specimens, and the presence of micro-cracks and discontinuities that could reduce their compressive strength, ultrasound tests were performed in all specimens before their failure in the compression tests. The values obtained are presented in Table 2.

As shown by Table 2, theaverage wave propagation speed is above $5,000 \mathrm{~m} / \mathrm{s}$, which, according to ABNT NBR NM 8802, indicates the excellent quality of the specimens tested and the absence of pathologies and non-visible heterogeneities that could reduce their compressive strength.

Leal (2012) obtained ultrasonic speed among 6,881 and $11,410 \mathrm{~m} / \mathrm{s}$ for concrete specimens aged 3, 7, 28, and 91 days. According to Naik et al. (2004), apud Leal (2012), the typical wave propagation velocity for good quality concretes ranges from 3,000 to $5,000 \mathrm{~m} / \mathrm{s}$.

According to Table 2, the compressive strength for C\&DW specimens ranged from 11.2 MPa to 32.5 MPa, resulting in an average value of $20 \mathrm{MPa}$, with standard error equal to 1.9 MPa. The average value is lower than determined by Leal (2012), who found an average of $33 \mathrm{MPa}$ for 28-day-old concretes. Martins (2008) performed compressive tests on concrete specimens (28 days aged) and obtained average compressive strengths among 28.8 and $49.1 \mathrm{MPa}$.

Figure 7 shows the correlation obtained between the ultrasound propagation velocity 
Table 1. Physical characterization of C\&DW specimens.

\begin{tabular}{ccccccc}
\hline Specimen & Diameter $(\mathbf{m m})$ & $\begin{array}{c}\text { Cross section } \\
\text { area }\left(\mathbf{m m}^{2}\right)\end{array}$ & Height $(\mathbf{m m})$ & Volume $\left(\mathbf{c m}^{3}\right)$ & Weight $(\mathbf{k N})$ & $\begin{array}{c}\text { Specific weight } \\
\left(\mathbf{k N} / \mathbf{m}^{3}\right)\end{array}$ \\
\hline CDW1 & 43.86 & 1510.1 & 89.28 & 134.8 & 0.299 & 22.18 \\
CDW2 & 43.60 & 1492.3 & 91.48 & 136.5 & 0.309 & 22.64 \\
CDW3 & 43.50 & 1485.4 & 91.22 & 135.5 & 0.300 & 22.14 \\
CDW4 & 43.82 & 1507.6 & 93.14 & 140.4 & 0.312 & 22.22 \\
CDW5 & 43.89 & 1512.2 & 92.22 & 139.5 & 0.325 & 23.31 \\
CDW6 & 44.00 & 1519.8 & 91.16 & 138.5 & 0.305 & 22.02 \\
CDW7 & 44.18 & 1532.2 & 91.77 & 140.6 & 0.307 & 21.83 \\
CDW8 & 44.26 & 1537.8 & 90.09 & 138.5 & 0.294 & 21.22 \\
CDW9 & 43.55 & 1488.8 & 91.65 & 136.5 & 0.326 & 23.89 \\
CDW10 & 43.83 & 1508.0 & 93.35 & 140.8 & 0.310 & 22.02 \\
Average & 43.85 & 1509.4 & 91.54 & 138.2 & 0.309 & 22.35 \\
$\begin{array}{c}\text { Standard } \\
\text { deviation (sd) }\end{array}$ & 0.30 & 0.000017 & 1.2 & 0.0 & 0.00 & 0.80 \\
$\begin{array}{c}\text { Coefficient of } \\
\text { variation - cv (\%) }\end{array}$ & 0.6 & 1.2 & 1.4 & 1.6 & 3.4 & 3.4 \\
\hline
\end{tabular}

and the compressive strength determined by the tests. A linear relationship $\left(R^{2}=0.81\right)$ between the compressive strength and the ultrasound velocity was obtained, demonstrating that the test specimens did not have micro-cracks or internal discontinuities that could influence the test results.

Specimens presentedn an average initial tangent elasticity modulus $\left(\mathrm{E}_{\mathrm{ci}}\right.$ ) equal to $21.2 \mathrm{GPa}$ ( $\mathrm{sd}=$ $7.7 \mathrm{GPa}, \mathrm{cv}=36.3 \%$ ). The average Initial Tangent Elasticity Modulus obtained for C\&DW is within a normal range for typical concretes. Melo Neto and

Table 2. Ultrasound propagation velocity and compressive strength of C\&DW specimens.

\begin{tabular}{ccc}
\hline Specimen & $\begin{array}{c}\text { Ultrasound } \\
\text { velocity }(\mathrm{m} / \mathrm{s})\end{array}$ & $\begin{array}{c}\text { Compressive } \\
\text { strength }(\mathrm{MPa})\end{array}$ \\
\hline CDW1 & $5,160.7$ & 17.60 \\
CDW2 & $5,197.7$ & 15.21 \\
CDW3 & $5,183.0$ & 18.22 \\
CDW4 & $5,511.2$ & 19.51 \\
CDW5 & $6,731.4$ & 26.83 \\
CDW6 & $5,627.2$ & 23.18 \\
CDW7 & $5,126.8$ & 16.38 \\
CDW8 & $5,207.5$ & 11.22 \\
CDW9 & $6,739.0$ & 32.46 \\
CDW10 & $5,692.1$ & 19.47 \\
Average & $5,617.7$ & 20.00 \\
Standard deviation & 623.4 & 6.10 \\
(sd) & & 30.5 \\
Coefficient of & 11.1 & \\
variation (\%) & & \\
\hline
\end{tabular}

Helene (2002) determined that $\mathrm{E}_{\mathrm{ci} 28}$ for different concrete dosages obtain values between 16.4 and 29.0 GPa. Leal (2012) found for concrete CA2O an $\mathrm{E}_{\mathrm{ci}}$ among 30.6 and $33.6 \mathrm{GPa}$. According to the authors, aging and weathering are the main responsible for concrete elasticity modulus reduction.

According to ABNT NBR 6118 (2014), the Initial Tangent Elasticity Modulus for concrete when tests are not available can be estimated using equation 1.

$$
E_{c i}=5600 \cdot\left(f_{c k}\right)^{1 / 2}
$$

Through the results of the C\&DW specimens in the broken natural state and knowing that they are adherent to a standard distribution curve, it is possible to determine through the results of the compression tests the characteristic fck of the waste concrete employing equations 2 and 3 :

$$
\begin{aligned}
& f_{c k}=f_{c j}-1.65 . s \\
& s=\left(\Sigma\left(f_{c c i}-f_{c j}\right)^{2} /(n-1)\right)^{1 / 2}
\end{aligned}
$$

Where:

$\mathrm{f}_{\mathrm{ci}}=$ value obtained in each test;

$\mathrm{f}_{\mathrm{cm}}=$ average value of strength;

$\mathrm{n}=$ number of tests. 


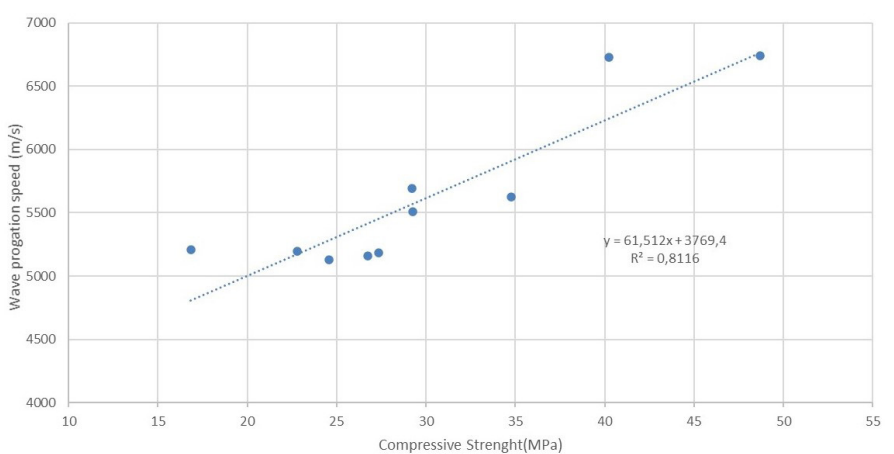

Fig. 7. Correlation between compressive strength and ultrasound velocity.

Considering the results obtained in the compression tests, $\mathrm{s}=4.38 \mathrm{MPa}$ and $\mathrm{f}_{\mathrm{ck}}=11 \mathrm{MPa}$. Therefore, $\mathrm{E}_{\mathrm{ci}}=18.6 \mathrm{GPa}$. According to equation from Martins (2008), $\mathrm{E}_{\mathrm{ci}}=20.0 \mathrm{GPa}$. According to Nunes (2005), $E_{c i}=20.0 \mathrm{GPa}$. According to Molin and Monteiro (1996), $\mathrm{E}_{\mathrm{ci}}=20.1 \mathrm{GPa}$. Then:

$E_{c i, a v e r a g e} / E_{c i}$ ABNT NBR $6118=21.2 / 18.6=1.14$

$\mathrm{E}_{\mathrm{ci} \text {,average }} / \mathrm{E}_{\mathrm{ci}}$ Martins $(2008)=21.2 / 19.9=1.06$

$E_{c i, a v e r a g e} / E_{c i}$ Nunes $(2005)=21.2 / 20=1.06$

$E_{c i \text { average }} / E_{c i}$ Molin and Monteiro (1996) $=21.2 / 20.12$ $=1.05$

Thus, through the values demonstrated, it can be assumed that the equations used to estimate the value of the Initial Tangent Elasticity Modulus allowed values close to the average value obtained for the wastes.

Absorption parameters were also obtained; the obtained data are presented in Table 3. The average absorption for C\&DW specimens was $5.0 \%$ ( $\mathrm{sd}=4.51 \%$ and $\mathrm{cv}=0.32 \%$ ), with values ranging from $3.99 \%$ to $5.08 \%$. According to Leal (2012), absorption is not proper for concrete quality characterization. However, according to the author, good quality concretes commonly presents absorption below $10 \%$. The same author performed absorption tests on concrete specimens CA2O, CA30, and CA40 aged 28 days; values ranging from 5.27 to $6.8 \%$ were determined.
Table 3. Ultrasound propagation velocity and compressive strength of C\&DW specimens.

\begin{tabular}{cc}
\hline Specimen & Water absorption (\%) \\
\hline CDW11 & 4.61 \\
CDW12 & 4.45 \\
CDW13 & 4.56 \\
CDW14 & 3.99 \\
CDW15 & 4.61 \\
CDW16 & 4.44 \\
CDW17 & 4.67 \\
CDW18 & 4.13 \\
CDW19 & 5.08 \\
CDW20 & 4.13 \\
Average & 5.00 \\
Standard deviation (sd) & 4.51 \\
Coefficient of variation (\%) & 0.32 \\
\hline
\end{tabular}

\section{Conclusions}

Through the results obtained, it is possible to state that the recycled C\&DW in its natural state had a specific weight of $22.35 \mathrm{kN} / \mathrm{m}^{3}$; its compressive strength was $30.1 \mathrm{MPa}$. The Initial Tangent Elasticity Modulus was $21.2 \mathrm{GPa}$, where the C\&DW is within a reasonable range of concrete. It is worth noting that the average wave speed obtained employing the ultrasound test for this analyzed set was 5,617.70 m/s, where, according to ABNT NBR 8802 , it indicates the excellent quality of the tested specimens and the absence of pathologies and non-visible heterogeneities that could influence the proposed tests.

The C\&DW used consists of a new alternative to one of the biggest problems faced by civil construction: the destination of the waste generated in the works. Thus, the use of C\&DW for civil construction can create and stimulate higher demand for recycled materials in the C\&DW Recycling Plants.

\section{References}

ASSOCIAÇÃO BRASILEIRA DE NORMAS TÉCNICAS. ABNT NBR NM 8522: Concrete - Determination of static modulus of elasticity and deformation by compression. Rio de Janeiro, ABNT, 2017. 
ABNT NBR NM 7680: Concrete - Sampling, preparing, testing, and result from the analysis of concrete cores Part 1: Axial compressive strength. Rio de Janeiro: ABNT, 2015.

ASSOCIAÇÃO BRASILEIRA DE NORMAS TÉCNICAS. ABNT NBR NM 8802: Hardened concrete Determination of ultrasonic wave transmission velocity. Rio de Janeiro: ABNT, 2010.

ASSOCIAÇÃO BRASILEIRA DE NORMAS TÉCNICAS.

ABNT NBR 9778: Hardened mortar and concrete - Determination of absorption, voids, and specific gravity. Rio de Janeiro, ABNT, 2009.

ARIF, M. et al. Construction waste management in India: an exploratory study. Construction Innovation, v. 12, n. 2, p. 133-155, 2012.

BLSAISI, N. I. Construction and demolition waste management in Saudi Arabia: current practice and roadmap for sustainable management. Journal of Cleaner Production, v. 221, p. 167-175, 2019.

CHEN, J.; HUA, C.; LIU, C. Considerations for better construction and demolition waste management: identifying contractors and government departments' decision-making behaviors through a game theory decision-making model. Journal of Cleaner Production, v. 212, p. 190-199, 2019.

DURAN, X.; LENINGHAN, H.; O'REGAN, B. A model for assessing the economic viability of construction and demolition waste recycling-the case of Ireland. Resources, Conservation, and Recycling, v. 46, n. 3, p. 302-320, 2006.

Eurostat (2017) Report: General and Regional Statistics. Available at: https://ec.europa.eu/ eurostat/publications/all-publications (Accessed July 10, 2019).

ESA, M. R.; HALOG, A.; RIGAMONTI, L. Developing strategies for managing construction and demolition wastes in Malaysia based on the concept of a circular economy. Journal of Material Cycles and Waste Management, v. 19, n. 3, p. 1144-1154, 2017.
Brazilian Institute of Geography and Statistics (IBGE) (2017). Statistical Series \& Historical Series. Retrieved March 24, 2018, from https:// seriesestatisticas.ibge.gov.br/

JIN, R.; YUAN, H.; CHEN, Q. Science mapping approach to assisting the review of construction and demolition waste management research published between 2009 and 2018. Resources, Conservation \& Recycling, v. 140, p. 175-188, 2018.

LEAL, W. R. S. Concrete dosed in a plant: proposal of quality control methodology and identification of the causes of variability in the concrete production process. Dissertation (Master Degree) - Federal University of Santa Catarina. 215p. 2012.

MAIA, A. T.; NETO, A. I. What are the main organizational characteristics of companies in the different segments of civil construction? Revista Ambiente Construído, v. 16, n. 3, p. 197-215, 2016.

MAHPOUR, A. Prioritizing barriers to adopt a circular economy in construction and demolition waste management. Resources \& Recycling, v. 134, p. 216-227, 2018.

MelO Neto, A. A.; Helene, P. Elasticity Module: Dosing and Evaluation of Concrete Elasticity Modulus Prediction Models. In: 44th Brazilian Concrete Congress, Belo Horizonte, 17-22 august 2002.

MENEGAKI, M.; DAMIGOS, D. A review on current situation and challenges of construction and demolition waste management. Current Opinion in Green and Sustainable Chemistry, v. 13, p. 8-15, 2018.

MIRANDA, L. F. R.; ANGULO, S. C.; CARELI, E. D. The recycling of construction and demolition waste in Brazill: 1986-2008. Constructed Environment, v. 9 n. 1, p. 57-71, 2009.

NAGAPAN, S.; RAHMAN, I. A.; ASMI, A. Factors Contributing to Physical and Non-Physical Waste Generation in the Construction Industry. International Journal of Advances in Applied 
Sciences, v. 1, n. 1, p. 1-10, 2012

OYEDELE, L. O. et al. Reducing waste to landfill in the UK: identifying impediments and critical solutions. World Journal of Science, Technology, and Sustainable Development, v. 10, n. 2, p. 131142, 2013.

PASCHOALIN FILHO, J. A. et al. Construction Waste Management in High Standard Residential Buildings in the Municipality of São Paulo/SP. Journal of Social and Environmental Management, v. 11, n. 1, p. 73-89, 2017.

YUAN, H. A model for evaluating the social performance of construction waste management. Waste Management, v. 32, n. 6, p. 1218-1228, 2012.

TAM, W. Y. V.; KOTHAYOTHAR, D.; LOO, Y. C. On the prevailing construction waste recycling practices: a South East Queensland study. Waste Management \& Research, v. 27, n. 2, p. 167-174, 2009.

WANG, J. et al. Considering life-cycle environmental impacts and society's willingness to optimize construction and demolition waste management fee: An empirical study of China. Journal of Cleaner Production, v. 206, p. 1004-1014, 2019. 


\title{
Teste acelerado de argamassas e a combinação de adições minerais ativas com agregado potencialmente reativo
}

\author{
Cleberson S. Adorno ${ }^{a}$, Eloise A. Langaro ${ }^{a}$, Marcelo H. F. Medeiros ${ }^{a}$, Andressa Gobbi \\ ${ }^{a}$ Universidade Federal do Paraná, Departamento de Construção Civil, Curitiba, Brasil.

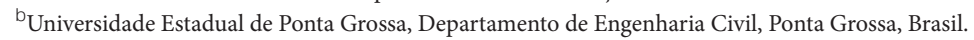

\section{Informações}

Recebido 15 Junho 2020

Manuscrito revisado recebido

2 Agosto 2020

Aceito 8 Agosto 2020

Palavras-chave

AMBT

Cinza de casca de arroz

Expansão

Porosimetria

\section{Resumo}

O teste acelerado de barras de argamassa (AMBT) é o mais rápido para detectar a reatividade de agregados. Porém, apresenta diversas limitações quanto à classificação, limites determinados e as condições de aceleração do ensaio. Quando se trata do AMBT para classificar adições minerais potencialmente inibidoras da RAS, a solução de $\mathrm{NaOH}$ e a alta temperatura são fatores cruciais. $\mathrm{O}$ presente trabalho visa investigar o efeito do AMBT no desenvolvimento da RAS em combinações de cimento com cinza de casca de arroz e sílica ativa. A expansão induzida foi usada para avaliar a cinética da RAS. Além disso, as propriedades químicas e físicas da matriz hidratada em condições normais de temperatura e umidade e em condições do ensaio foram caracterizadas por DRX, TGA e MIP. A finura e o tamanho das partículas da cinza de casca de arroz foram determinantes na mitigação da RAS. As condições do AMBT são agressivas demais para descartar um material apenas pelos resultados de expansão. Os mecanismos de atuação das adições minerais frente a RAS devem ser mais bem entendidos e avaliados perante o uso de ensaios que não comprometam seu desenvolvimento.

\section{Accelerated test of mortars}

\section{Article info}

Received 15 June 2020

Received in revised form 2 August 2020

Accepted 8 August 2020

\section{Keywords}

AMBT

Rice husk ash

Expansion

Porosimetry

\begin{abstract}
The accelerated test of mortar bars (AMBT) is the fastest to detect the reactivity of aggregates. However, it presents several limitations regarding the classification, limits and the conditions to accelerate the test. When AMBT is used to classify mineral additions that potentially inhibit RAS, $\mathrm{NaOH}$ solution and high temperature are crucial factors. The present work aims to investigate the effect of AMBT on the development of RAS in combinations of cement with rice husk ash and silica fume. The induced expansion was used to assess the kinetics of RAS. In addition, the chemical and physical properties of the hydrated matrix under normal conditions of temperature and humidity and under test conditions were characterized by XRD, TGA and MIP. The fineness and particle size of rice husk ash were determinant in the mitigation of RAS. AMBT conditions are too aggressive to discard a material just by the determination of expansion. The mechanisms of action of mineral additions subjected to RAS must be better understood and evaluated by using tests that do not compromise their development.
\end{abstract}

\section{Ensayo acelerado de morteros}

\section{Información}

Recibido 15 Juni 2020

Manuscrito revisado recibido 2 Agosto 2020

Aceptado 8 Agosto 2020

\section{Palabras clave}

AMBT

Ceniza de cáscara de arroz

Expansion

Porosimetria

\section{Resumen}

El ensayo acelerado de barras de mortero (AMBT) es lo más rápido para detectar la reactividad de áridos. Sin embargo, presenta varias limitaciones cuanto a la clasificación, los límites determinados y las condiciones para acelerar el ensayo. Cuando se usa el AMBT para clasificar adiciones minerales potencialmente inhibidoras de la RAS, la solución de $\mathrm{NaOH}$ y las altas temperaturas son factores cruciales. El presente trabajo tiene como objetivo investigar el efecto del AMBT en el desarrollo de la RAS en mezclas de cemento con ceniza de cáscara de arroz y humo de sílice. La expansión inducida se utilizó para evaluar la cinética de la RAS. Las propiedades químicas y físicas de la matriz hidratada en condiciones normales de temperatura y humedad y en condiciones de ensayo se caracterizaron por DRX, TGA y MIP. La finura y el tamaño de partícula de la ceniza fueron determinantes para mitigar la RAS. Las condiciones del AMBT son demasiado agresivas para descartar un material solamente por la determinación de la expansión. Los mecanismos de acción de las adiciones minerales frente a la RAS deben entenderse y evaluarse mejor antes de utilizar pruebas que no comprometan su desarrollo.

\footnotetext{
* Autor correspondente em: Universidade Estadual de Ponta Grossa, Departamento de Engenharia Civil, Ponta Grossa, Brasil.

E-mail: agobbi@uepg.br (A. Gobbi)
}

https://doi.org/10.47842/juts.v3i1.23

ISSN: 2675-780X 


\section{Introdução}

A durabilidade relacionada ao tempo de vida útil das estruturas de concreto armado é fator preponderante nas construções atuais. A observância de aspectos relativos à escolha dos materiais, de acordo com o local de inserção da nova estrutura, deve ser considerada como ponto de partida para garantia da durabilidade. Manifestações patológicas como a reação álcalisílica (RAS) decorrem da escolha incorreta de materiais e do uso de agregados potencialmente reativos em ambientes propícios a ocorrência. Uma simples avaliação preliminar das condições e dos agregados pode evitar danos futuros que por muitas vezes se tornam irreparáveis.

Ensaios normatizados, como os previstos na NBR 15577 (2018), ASTM C 1260 (2014), CAN/ CSA A-23.2-25A-14 (2014), UNE 146508 (2018) e em outros países, já conseguem antecipar, antes do lançamento da construção, que o agregado a ser utilizado no concreto tem potencial reativo para desencadear uma reação deletéria. E um dos ensaios amplamente discutidos na comunidade científica, é o teste acelerado das barras de argamassa, conhecido como AMBT Accelerated Mortar Bar Test. Ele é reconhecido por apresentar resultados rápidos para classificação dos agregados, geralmente em torno de 14 até 30 dias. Porém devido as suas condições severas de aplicação, temperatura elevada $\left(80{ }^{\circ} \mathrm{C}\right)$ e o uso de solução altamente alcalina (uso de $\mathrm{NaOH}$ ), tem sido bastante criticado por diversos autores (FOURNIER e BÉRUBÉ, 2000; THOMAS et al., 2006; ALAEJOS et al., 2014; LATIFEE e RANGARAJU, 2015; GOLMAKANI E HOOTON, 2016; DESCHENES E MICAH HALE, 2017).

As críticas em torno do AMBT são de classificações errôneas, com resultados falso positivos e falso negativos, que podem ser gerados com o método. Certos tipos de agregados tem uma reação lenta ao longo do tempo tornando alguns resultados incorretos, ou seja, falsos-negativos (aqueles agregados que se mostram inofensivos, mas ao longo do tempo mostram potencial reativo). Além disso, podem ocorrer também os falsos positivos, aqueles cujo resultado descarta o uso do agregado, mas poderiam ser utilizados sem problemas nos elementos de concreto (FOURNIER et al., 2006). O teste é severo demais para agregados com boa performance sendo não recomendando para rejeitação, e sim apenas para aceitação (FOURNIER e BÉRUBÉ, 2000; LINDGARD et al., 2012).

Combinações entre materiais como pozolanas, e agregados reativos também podem ser testados a partir do AMBT. A mesma metodologia e limites de expansão são aplicados com o intuito de classificar se o material tem capacidade de inibir a reação álcali-agregado. Nenhum ajuste foi feito por parte das normas com relação a essa classificação.

É reconhecido que as fases amorfas das adições minerais ativas podem reagir $\mathrm{com} \mathrm{Ca}(\mathrm{OH})_{2}$ e formar produtos hidratados pozolânicos, como o C-S-H, reduzindo a quantidade de hidróxidos e $\mathrm{o} \mathrm{pH}$ da solução de poros do concreto, sendo capaz de limitar a ocorrência de reação álcali-sílica (AQUINO et al., 2001; HASPARYK et al., 2001; THOMAS, 2011). Porém, quando o AMBT é usado para avaliar as adições neste contexto, as condições relativas à solução alcalina de hidróxido de sódio e a temperatura elevada $\left(80^{\circ} \mathrm{C}\right)$ tornam-se cruciais no desempenho dos materiais. A fonte de álcalis externa é inesgotável e, portanto, muitas adições ativas conseguem apenas reduzir a penetração da solução temporiariamente, retardando a ocorrência da reação e a taxa de expansão (THOMAS et al., 2007).

Apesar da elevada temperatura propiciar a aceleração da reação pozolânica das adições minerais ativas, entender os mecanismos por traz dessa aceleração se faz necessária, uma vez que adições consideradas altamente reativas, como é o caso da cinza de casca de arroz, muitas vezes não consegue mitigar a expansão ocasionada pela RAS (AHSAN e HOSSAIN, 2018).

Neste contexto, o objetivo desta pesquisa foi avaliar o teste acelerado de barras de argamassa perante o uso da combinação de um agregado potencialmente reativo e adições minerais ativas como a sílica ativa e a cinza de casca de arroz. Modificações da microestrutura dos materiais nas condições do AMBT (solução de $\mathrm{NaOH}$ e temperatura elevada) foram comparadas a 
condições normais de umidade e temperatura para desenvolvimento da argamassa. Difração de raios- $X$, termogravimetria e porosimetria por intrusão de mercúrio foram utilizados para analisar os mecanismos físicos e químicos das adições no desempenho frente a reação álcali-sílica.

\section{Programa experimental}

\subsection{Materiais}

Foi utilizado cimento Portland, do tipo CPVARI, como referência desse estudo, em razão da ausência de adições minerais ativas em sua composição. O CPV-ARI é equivalente ao cimento tipo III, cimento Portland de alta resistência inicial, de acordo com a ASTM C150 e tipo I, com classe R de resistência à compressão, segundo a EN 197-1. A Tabela 1 apresenta as caracteristicas químicas e físicas do cimento.

A cinza de casca de arroz (CCA) proveniente da queima controlada em leito fluidilizado e a sílica ativa (SA) usadas neste experimento apresentaram massa específica de $2,12 \mathrm{~g} / \mathrm{cm}^{3}$ e $2,18 \mathrm{~g} / \mathrm{cm}^{3}$, respectivamente.

A curva granulométrica dos materiais está apresentada na Figura 1(A) e foi obtida utilizando um granulômetro a laser via úmido. É possível observar

Tabela 1. Propriedades químicas e físicas do cimento.

\begin{tabular}{cc}
\hline Propriedade & Resultado \\
\hline $\mathrm{CaO}$ & 59,36 \\
$\mathrm{SiO}_{2}$ & 16,27 \\
$\mathrm{Al}_{2} \mathrm{O}_{3}$ & 5,06 \\
$\mathrm{SO}_{3}$ & 5,30 \\
$\mathrm{Fe}_{2} \mathrm{O}_{3}$ & 2,77 \\
$\mathrm{MgO}$ & 4,63 \\
$\mathrm{~K}_{2} \mathrm{O}$ & 1,06 \\
$\mathrm{Na}_{2} \mathrm{O}_{\text {eq }}$ & 0,697 \\
$\mathrm{CaOlivre}$ & 1,46 \\
Resíduo insolúvel $(\%)$ & 0,67 \\
Perda ao fogo $(\%)$ & 3,43 \\
Finura Blaine $\left(\mathrm{cm}^{2} / \mathrm{g}\right)$ & 4510 \\
Finura BET $\left(\mathrm{cm}^{2} / \mathrm{g}\right)$ & 1,070 \\
Massa específica $\left(\mathrm{g} / \mathrm{cm}^{3}\right)$ & 3,13 \\
\hline
\end{tabular}

na Figura 1(B) os pontos que correspondem aos tamanhos de partícula 50 (diâmetro médio) e $90 \%$ sobre a distribuição cumulativa. A sílica ativa apresentou $D_{50}=0,25 \mu \mathrm{m} \mathrm{e} D_{90}=2,0 \mathrm{\mu m}$, inferiores aos demais materiais, seguido do cimento e da cinza de casca de arroz.

A Tabela 2 mostra a análise química das adições minerais (realizada por fluorescência de raios-X), assim como o equivalente alcalino, a área superficial específica (BET) e a perda ao fogo (LOI). $\mathrm{Na}$ constituição de ambas as adições ativas há predominância de sílica e pequenas quantidades de outros elementos como alumina, anidrido sulfúrico, óxido de ferro e cal. O carbono (LOI) e potássio (álcalis) se apresentam em quantidades ligeiramente superiores na CCA. Quando se trata de reação álcali-sílica, a quantidade de carbono e o equivalente alcalino podem contribuir negativamente para o controle da expansão (SHEHATA e THOMAS, 2000). A cinza de casca de arroz atende o limite estabelecido pela ASTM C618, que regula o uso de cinzas em concreto, quanto a especificação de LOI, que é $6 \%$.

A reatividade da cinza de casca de arroz é regulada principalmente pela quantidade de sílica amorfa disponível para a reação pozolânica. Dessa forma, a presença de fases cristalinas impacta de forma negativa na pozolanicidade da adição. As fases mineralógicas da cinza de casca de arroz e da sílica ativa foram identificadas por difratometria de raios- $X$, em equipamento Rigaku modelo Ultima IV. A análise foi realizada entre 5 e $75^{\circ} 2 \theta$, com passo angular de $0,02{ }^{\circ} 2 \theta$ e tempo por passo de 1 segundo. O difratograma da cinza de casca de arroz é mostrado na Figura 2.

O difratograma caracteriza uma estrutura amorfa na cinza de casca de arroz contendo apenas uma pequena parcela organizada como cristobalita, que é uma forma polimórfica do dióxido de silício. No difratograma da sílica ativa não foram observados picos característicos, mostrando uma estrutura predominantemente amorfa (Figura 3).

A capacidade das adições ativas em fixar cal por atividade pozolânica, foi determinada pelo ensaio Chapelle modificado. No Brasil, o método Capelle modificado é normalizado de acordo com 

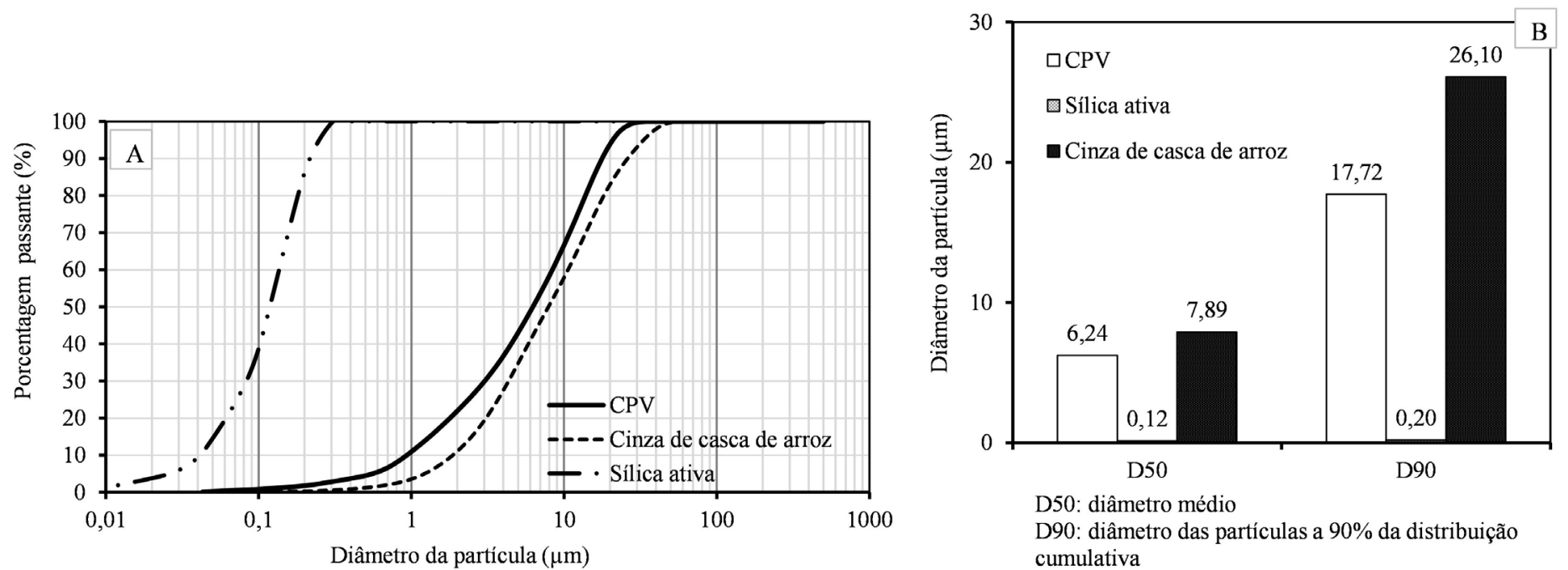

Fig. 1. Distribuição granulométrica dos materiais.

a NBR 15895. Segundo Quarcioni et al. (2015), esse método foi originalmente proposto por estudos de Raverdy et al. (1980), e é um método direto para a determinação da reatividade pozolânica de diferentes materiais. Este ensaio consiste, basicamente, em manter sob agitação, por um período de (16 \pm 2 ) horas, à temperatura de (90 $\pm 5{ }^{\circ} \mathrm{C}$, uma mistura de $1,0 \mathrm{~g}$ de adição mineral e 2,0 g de óxido de cálcio ( $\mathrm{CaO}$ ) em $250 \mathrm{~mL}$ de água, acondicionada em Erlenmeyer polimérico. Os resultados são obtidos por titulação e expressos pela quantidade de hidróxido de cálcio fixado por g de adição. O consumo de $330 \mathrm{~g} \mathrm{CaO/g}$ de adição corresponde a $436 \mathrm{mg} \mathrm{Ca}(\mathrm{OH})_{2} / \mathrm{g}$, que é o limite estabelecido para classificar uma adição como pozolânica.

A cinza de casca de arroz apresentou elevada

Tabela 2. Propriedades químicas e físicas das adições minerais.

\begin{tabular}{ccc}
\hline Propriedade & CCA & SA \\
\hline $\mathrm{CaO}$ & 0,43 & 0,19 \\
$\mathrm{SiO}_{2}$ & 88,47 & 92,35 \\
$\mathrm{Al}_{2} \mathrm{O}_{3}$ & 2,72 & 2,21 \\
$\mathrm{SO}_{3}$ & 1,55 & 1,52 \\
$\mathrm{Fe}_{2} \mathrm{O}_{3}$ & 0,05 & 0,05 \\
$\mathrm{MgO}_{\mathrm{K}} \mathrm{O}$ & - & - \\
$\mathrm{Na}_{2} \mathrm{O}_{\text {ea }}$ & 1,46 & 0,94 \\
Outros óxidos & 0,961 & 0,619 \\
Perda ao fogo (\%) & 0,49 & 0,04 \\
Finura BET (cm $/ \mathrm{g})$ & 4,84 & 2,70 \\
\hline
\end{tabular}

capacidade em fixar cal, resultando em 1336 mg $\mathrm{Ca}(\mathrm{OH})_{2} / \mathrm{g}$ de pozolana, valor próximo ao da sílica ativa, $1542 \mathrm{mg} \mathrm{Ca}(\mathrm{OH})_{2} / \mathrm{g}$. Esses resultados são superiores ao limite de classificação que é 436 mg $\mathrm{Ca}(\mathrm{OH})_{2} / \mathrm{g}$ de pozolana.

O agregado reativo utilizado foi obtido na região de Curitiba (Brasil), escolhido por ter histórico de manifestações patológicas diagnosticadas como reação álcali-agregado em obras hidráulicas nacionais (VALDUGA, 2007). O agregado é classificado como feldspato de potássio (ASTM C 294: 2017) devido à sua composição química indicar picos característicos de sanidina e albita (Figura 4). A composição química do agregado, obtida por fluorescência de raios-X, é constituída de $\mathrm{SiO}_{2}(63,5 \%), \mathrm{Al}_{2} \mathrm{O}_{3}(15,1 \%), \mathrm{Fe}_{2} \mathrm{O}_{3}(7,0 \%), \mathrm{K}_{2} \mathrm{O}$ (6,6\%), $\mathrm{Na}_{2} \mathrm{O}(4,4 \%)$ e $\mathrm{CaO}(2,1 \%)$, e outros óxidos com porcentagem abaixo de 0,5\%. 0 alto teor de potássio pode contribuir para a liberaração de quantidades significativas de álcalis na solução de poros do concreto. Em condições normais, a liberação de álcalis acelera significativamente o processo de deterioração do concreto (CONSTANTINER e DIAMOND, 2003; LOCATI et al., 2010).

\subsection{Proporções das misturas e teste acelerado das barras de argamassa}

As proporções das misturas consideram substituição parcial do cimento Portland, em massa, pelas adições de sílica ativa e cinza de casca de arroz, em um teor de $10 \%$. O traço utilizado da mistura de 


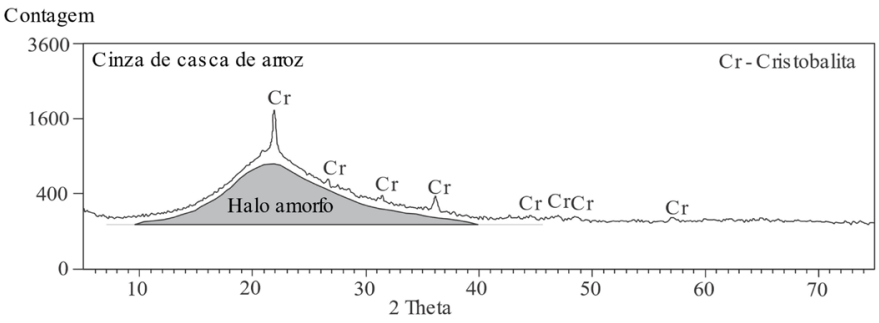

Fig. 2. Difratograma da cinza de casca de arroz.

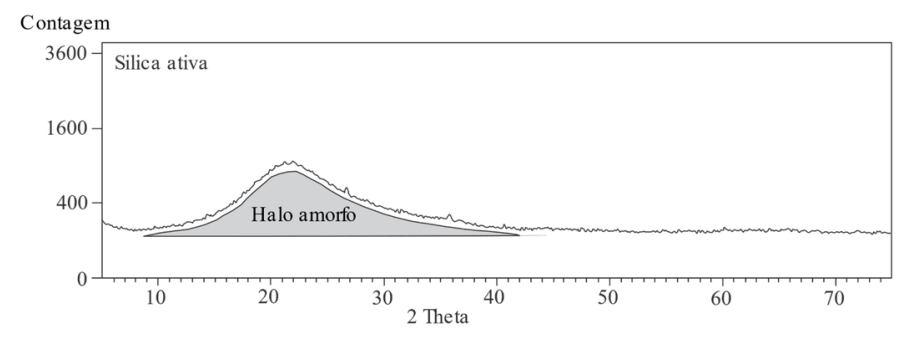

Fig. 3. Difratograma da sílica ativa.

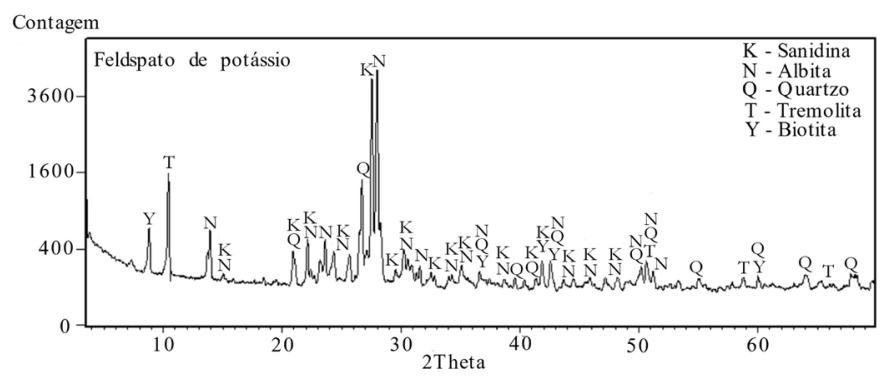

Fig. 4. Difratograma da sílica ativa.

referência, de acordo com NBR 15577:2018 parte 4 e 5, foi 1:2,25:0,47 (cimento: agregado miúdo: relação água/aglomerante). O agregado reativo foi inicialmente preparado utilizando o moinho de bolas Los Angeles e posteriormente dividido nas frações granulométricas requeridas pela norma.

Foram moldados 6 corpos de prova prismáticos para cada série, nas dimensões de 2,5 × 2,5 × 28,5 $\mathrm{cm}$. Após a moldagem, todos os corpos de prova foram submetidos a cura em câmara úmida por 24 horas. E, após a desmoldagem, 3 corpos de prova de cada série foram submetidos as condições especificadas pela norma, 24h em água a $80 \pm$ $2{ }^{\circ} \mathrm{C}$ e posterior imersão em solução de hidróxido de sódio $(\mathrm{NaOH}-1 \mathrm{~N})$ a $(80 \pm 2){ }^{\circ} \mathrm{C}$ durante 30 dias; e os outros 3 (grupo de controle em água destilada) foram mantidos em água destilada em temperatura ambiente (aproximadamente $24^{\circ} \mathrm{C}$ ). $\mathrm{O}$ segundo grupo, imerso apenas em água destilada, foi moldado com a finalidade de observar as diferenças microestruturais que o ensaio acelerado de barras de argamassa provoca.

As leituras de expansão nas barras foram realizadas em 24 horas (inicial) e duas vezes por semana, durante todo o período do ensaio. A expansão induzida foi medida comparando-se a medida inicial e a medida realizada ao longo do período de exposição.

\subsection{Análise da microestrutura}

Análises das mudanças na microestrutura das barras por difração de raios-X (DRX), termogravimetria (TG/DTG) e porosimetria por intrusão de mercúrio (MIP) foram realizadas. Essas análises tiveram o intuito de entender as transformações da microestrutura devido a ação da RAS, adições minerais ativas e também do teste acelerado. Após o período de expansão das barras (30 dias), todas as amostras de ambos os grupos (em solução e controle) foram fragmentadas e imergidas em álcool etílico p.a. por 24 horas para secagem e interrupção do processo de hidratação. Em seguida, os fragmentos foram colocados em estufa a $40{ }^{\circ} \mathrm{C}$ por mais 24 horas para completar o processo.

Após o período de secagem em estufa a $40{ }^{\circ} \mathrm{C}$, as amostras foram finamente moídas (<44 Nm) para realização do ensaio de DRX e de termogravimetria. Para a difração de raios-X, foi utilizada a faixa de varredura de 3,5 a $70{ }^{\circ} 2 \theta$, com passo angular de 0,017 20 e tempo de 10,16s por passo, utilizando o difratômetro PANALYTICAL modelo EMPYREAN detector X'Celerator. Para a análise termogravimétrica (TG/DTG) foi utilizado o equipamento da TA Instruments modelo SDT 2960, em atmosfera dinâmica de nitrogênio $\left(\mathrm{N}_{2}\right)$ e fluxo de $100 \mathrm{~mL} / \mathrm{min}$. As amostras já finamente moídas (<44 jm), foram colocadas em um cadinho de alumina, como porta amostra, e seguiram para a realização do ensaio. A taxa de aquecimento foi de $10{ }^{\circ} \mathrm{C} / \mathrm{min}$., aplicada até $1200{ }^{\circ} \mathrm{C}$.

Para a análise de porosimetria por intrusão de mercúrio foram utilizados os fragmentos das barras de argamassa, os quais foram secos em estufa a uma temperatura média de $100{ }^{\circ} \mathrm{C}$ por 24 horas. Após o resfriamento à temperatura ambiente, as 
amostras foram colocadas em um porta amostra com mercúrio. O princípio da metodologia para a análise consistiu em medir o volume de intrusão de mercúrio por grama de amostra ( $\mathrm{mL} / \mathrm{g})$, característico de cada pressão aplicada (inicial pressão de 1,5 psi a 30 psi; alta pressão - de 30 psi a 61000 psi), possibilitando expressar este volume em função do diâmetro dos poros.

Com base nos valores de porosidade total, existem teorias que definem o cálculo da permeabilidade absoluta a partir das propriedades mensuráveis do sistema cimentício, como porosidade $(\varphi)$, diâmetro médio dos poros $(d)$ e tortuosidade $(\tau)$, por exemplo. Katz e Thompson em 1986, baseados na lei de Darcy, propuseram um modelo para o cálculo da permeabilidade que relaciona a condutividade no material $(\sigma)$ com a condutividade do espaço poroso do mesmo $\left(\sigma_{0}\right)$, comprimento característico do espaço dos poros $\left(I_{c}\right)$ e uma constante de permeabilidade $c=0,0042$ (KATZ e THOMPSON, 1986). A permeabilidade absoluta calculada está descrita na Equação. 1. O equipamento de medição se baseia neste modelo para o cálculo da permeabilidade.

$$
k=c * l c^{2} \frac{\sigma}{\sigma_{0}}
$$

\section{Resultados e discussões}

\subsection{Teste acelerado em barras de argamassa (AMBT)}

Para o teste acelerado das barras de argamassa o limite de expansão da NBR 15577-1 que indica se um agregado pode ser classificado como "seguro", é estabelecido como a expansão total menor que 0,19\% aos 30 dias de exposição. Esse mesmo limite se aplica ao material inibidor da reação, no caso das pozolanas.

Os resultados da expansão das barras de argamassa submetidas as condições do AMBT estão apresentadas na Figura 5.

É possível observar que a argamassa de referência não ultrapassou o limite de expansão estipulado pela norma (0,19\%) no período de análise (30 dias). Isso indica que o agregado não apresentou potencial reativo nesse ensaio. Quanto ao uso das adições minerais, observa-se que ambas exibiram certa capacidade de minimização da expansão ocasionada pela RAS. Porém, a adição de cinza de casca de arroz apresentou menor potencial mitigador quando comparada a argamassa com sílica ativa.

Os resultados obtidos para a expansão das barras de argamassa foram validados utilizando análise estatística. A Análise de Variância (ANOVA) oneway com Teste de comparação múltipla de Tukey, considerando um intervalo de confiança de 95\%, indicou haver diferença estatística significativa na expansão entre todas as séries de barras analisadas na idade de 30 dias (Figura 6).

Apesar da cinza de casca de arroz ser considerada uma adição de alta reatividade, apresentando elevada capacidade de fixar cal no resultado do teste de Chapelle modificado (1336 mg $\mathrm{Ca}(\mathrm{OH})_{2} / \mathrm{g}$ de pozolana), alguns fatores relacionados ao material, como composição química e finura, podem ter

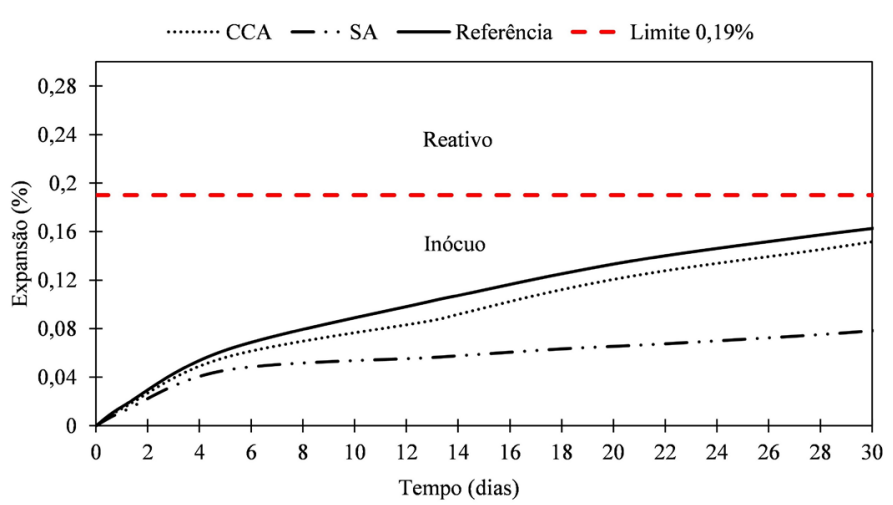

Fig. 5. Evolução da expansão das barras de argamassa.

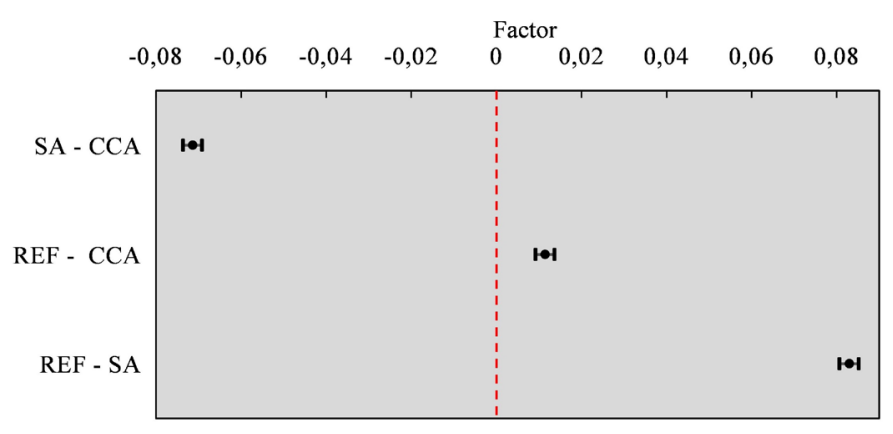

Fig. 6. Análise comparative de Tukey das amostras submetidas ao ensaio AMBT, aos 30 dias. 
contribuído negativamente para seu desempenho. A pequena diferença entre a expansão das barras de referência e das com CCA indicam que seus mecanismos não foram suficientes para inibir a reação ao nível da sílica ativa. Em contrapartida as condições do teste acelerado, temperatura elevada $\left(80{ }^{\circ} \mathrm{C}\right)$ e solução agressiva $(\mathrm{NaOH} 1 \mathrm{~N})$, podem ter dificultado o efeito positivo da atividade pozolânica desenvolvida por esta adição.

Quando é observada apenas a barra de referência, o resultado de expansão total não ultrapassa o limite estabelecido pela NBR 15577, o que confere ao teste a aos limites estabelecidos uma certa incerteza uma vez que este agregado já foi diagnosticado como reativo devido a fissuras, características da RAA, causadas em uma obra de barragem no Brasil.

O ensaio AMBT tem sido criticado em vários trabalhos (FOURNIER e BÉRUBÉ, 2000; THOMAS et al., 2006; GOLMAKANI e HOOTON, 2016; DESCHENES e MICAH HALE, 2017) por apresentar tendência a "falso positivo" e "falso negativo". Um exemplio é que alguns agregados podem apresentar o desenvolvimento da RAS mais lento, sugerindo assim que os limites propostos pelas normas são inadequados (ALAEJOS et al., 2014). Latifee e Rangaraju (2015) apontam as limitações do teste AMBT em sua pesquisa e, comentam que a questão da moagem excessiva dos agregados e o uso de temperatura elevada no teste podem alterar a reatividade dos agregados e das adições, o que prejudica o resultado final do ensaio.

É reconhecido, portanto, que o teste acelerado em argamassas não é o mais indicado para classificar um agregado como reativo ou um material como inibidor da RAS. Limites distintos em diferentes normas são apontados e, apesar de agregados diferentes serem encontrados em cada região do mundo, é aconselhável que testes em concreto e principalmente em campo sejam realizados.

\subsection{Difração de raios- $X$}

O difratograma da série de referência com cimento Portland CPV-ARI, coletado após o período de ensaio de expansão, é apresentado na Figura 7. Os compostos identificados são referentes a argamassa, ou seja, contém também componentes presentes do agregado utilizado. A intensidade dos picos foi normalizada. No difratograma é possível observar a influência da solução de $\mathrm{NaOH} 1 \mathrm{~N}$ e da temperatura a $80^{\circ} \mathrm{C}$ nos compostos das amostras submetidas ao ensaio AMBT e compará-los aos compostos formados nas argamassas mantidas em água destilada.
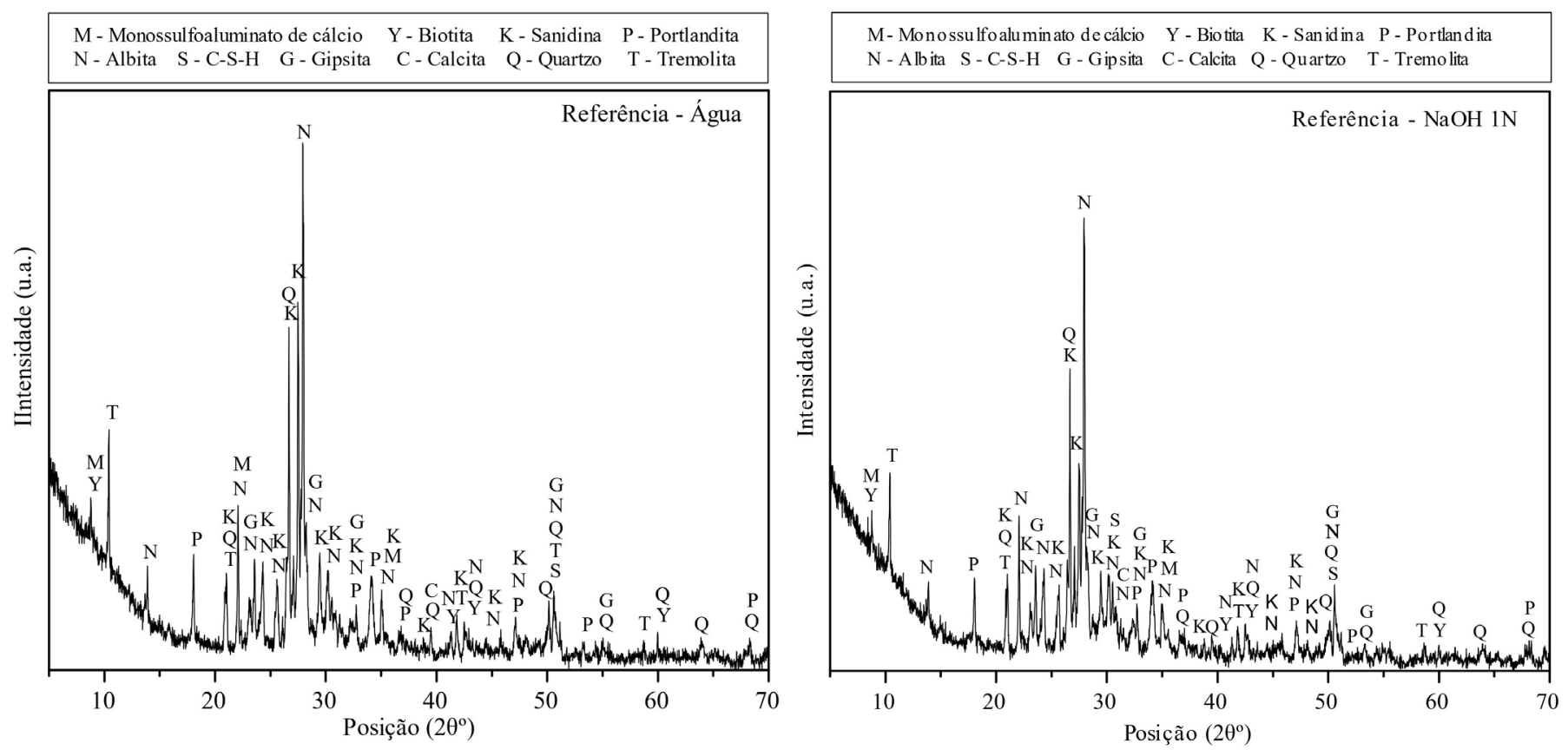

Fig. 7. Difratograma da série de referência em água destilada e solução de $\mathrm{NaOH} 1 \mathrm{~N}$. 

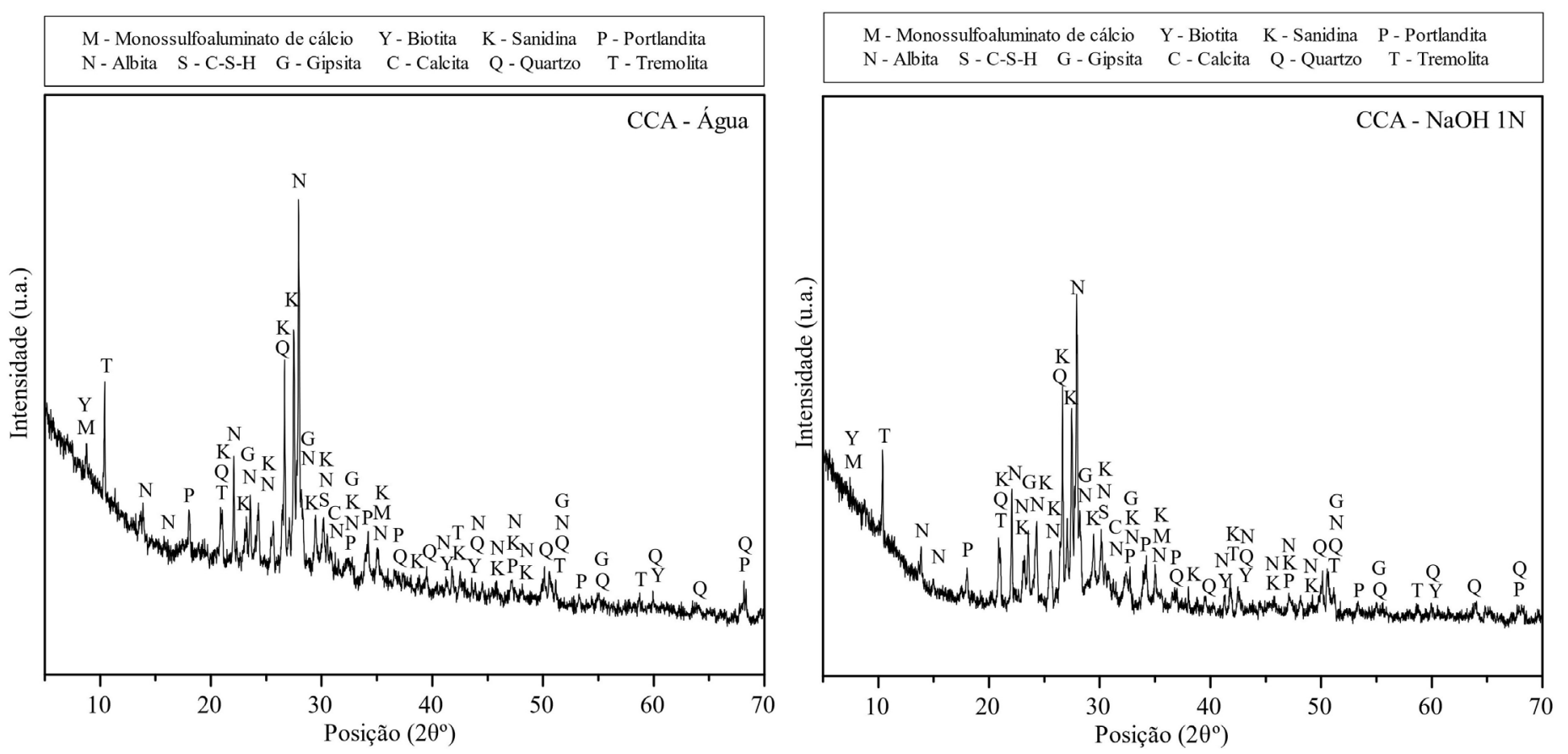

Fig. 8. Difratograma da série com cinza de casca de arroz em água destilada e solução de $\mathrm{NaOH} 1 \mathrm{~N}$.
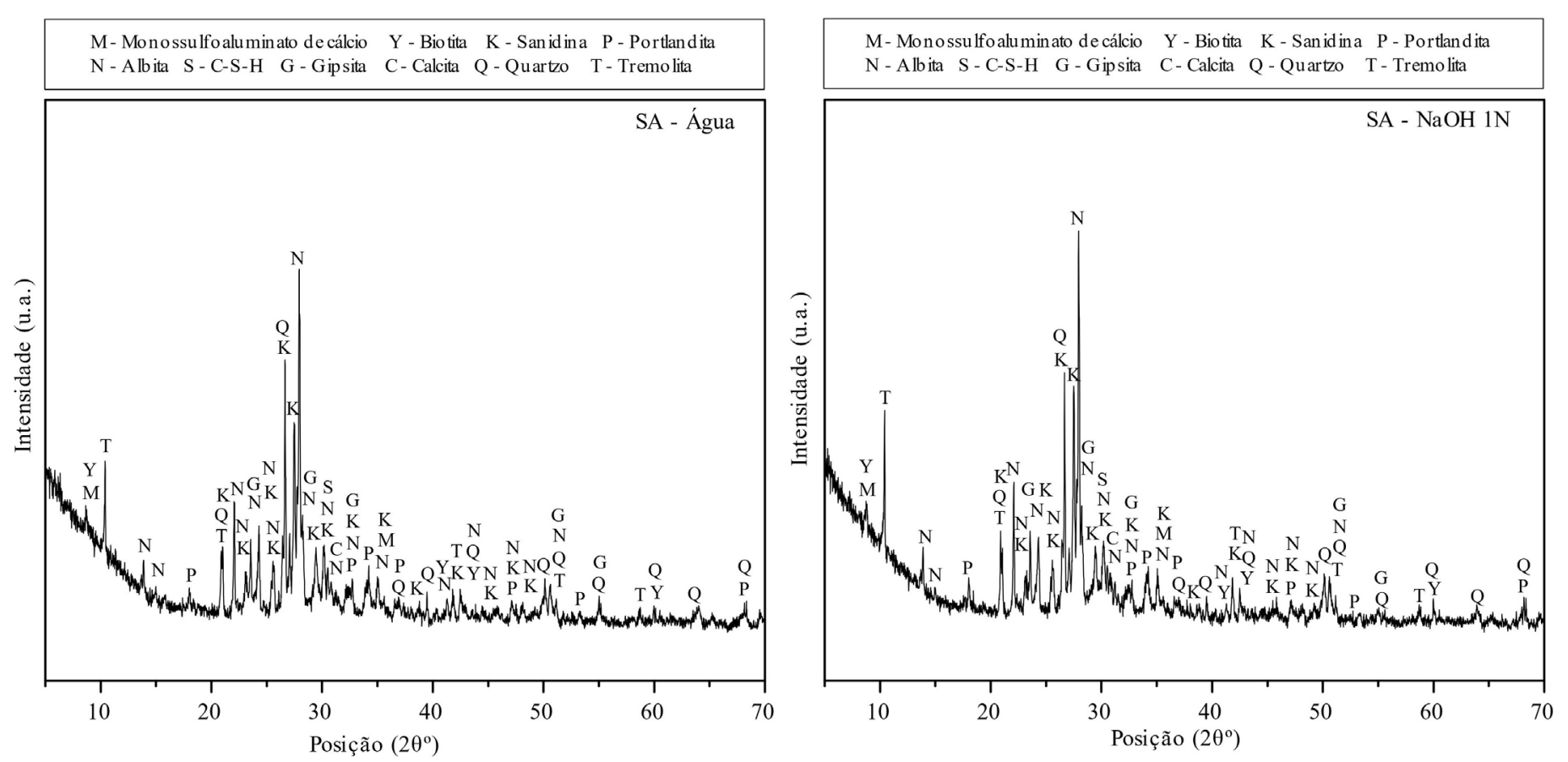

Fig. 9. Difratograma da série com sílica ativa em água destilada e solução de $\mathrm{NaOH} 1 \mathrm{~N}$.

O AMBT fornece uma fonte inesgotável de álcalis, pela solução de $\mathrm{NaOH}$, o que faz aumentar rapidamente a concentração alcalina nos poros e dessa forma, o desenvolvimento da RAS é acelerada.

A análise comparativa se deu referente aos picos de maior intensidade da sanidina $\left(27,46^{\circ} 2 \theta\right)$ e albita $\left(27,89{ }^{\circ} 2 \theta\right)$, devido ao uso do agregado. A sanidina $\left(\mathrm{KAISi}_{3} \mathrm{O}_{8}\right.$ ) e albita $\left(\mathrm{NaAlSi}_{3} \mathrm{O}_{8}\right.$ ) são apontadas como minerais que tendem a liberar álcalis podendo ser parcialmente consumidos na reação álcali- sílica (LNEC E 461, 2007). Desse modo, uma redução na quantidade deste composto poderia indicar ocorrência da RAS no sistema cimentício (BROEKMANS, 2012).

É possível observar que há uma pequena diminuição dos compostos referentes ao agregado (sanidina e albita) na série de referência submetida a solução de $\mathrm{NaOH}$, evidenciando que a condição do ensaio pode contribuir na dissolução dos álcalis disponíveis na argamassa. 
As Figuras 8 e 9 mostram os difratogramas das séries com cinza de casca de arroz e sílica ativa em ambas as condições (água destilada e solução de $\mathrm{NaOH}$ ). Assim como ocorreu na serie de referência, a Figura 8 mostra que a argamassa com CCA apresentou redução nos picos de sanidina e albina comparando o ensaio AMBT com a série em água. Por outro lado, a série com a SA (Figura 9) mostrou alteração na sanidina e albita, indicando a mitigação da RAS.

O pico principal relativo a portlandita $\left(34,1^{\circ} 2 \theta\right)$ para todas as amostras contendo as adições de sílica ativa e cinza de casca de arroz, foi inferior a série de referência, em ambas as condições de ensaio (água destilada e solução de $\mathrm{NaOH}$ ). $\mathrm{O}$ consumo da portlandita pode indicar que houve a reação pozolânica por parte das adições. Estudos realizados por Medeiros et al. (2017) apontaram resultados semelhantes para amostras de cimento Portland com adições e substituições parciais de metacaulim e sílica ativa quando comparadas ao cimento Portland CPV-ARI puro. A reação pozolânica dos adições minerais melhora a microestrutura das barras de argamassa, diminuindo a porosidade, a permeabilidade, levando a um material mais denso com melhores propriedades mecânicas e químicas, formando C-S-H pozolânico (produto estável), reduzindo o pH da solução de poros e contribuindo para limitar o dano causado pela RAS (AQUINO et al., 2001; HASPARYK et al., 2001; THOMAS et al., 2011; RÊGO et al., 2015; ABBAS et al., 2017).

Entretanto, mesmo que os resultados de DRX indiquem o consumo de portlandita devido à atividade pozolânica, as condições do ensaio AMBT podem ter atrapalhado o efetivo efeito das adições. De acordo com Thomas et al. (2007), as pozolanas reduzem a concentração de álcalis $(\mathrm{Na}+\mathrm{K})$ na solução dos poros em mais de 50\%. Porém quando há uma fonte inesgotável de álcalis, como é o caso da condição do ensaio, a pozolana retarda apenas o processo da RAS, impendindo inicialmente a entrada da solução, devido suas características e efeitos físicos (efeito fíller) e químicos (atividade pozolânica). Com o passar do tempo, os álcalis tendem a entrar em equilíbrio e a adição apenas serve como retardador da taxa de expansão.

\subsection{Análise termogravimétrica (TGA)}

Três principais faixas de perda de massa foram identificadas na análise de TG: primeira de 35 ${ }^{\circ} \mathrm{C}$ a $370{ }^{\circ} \mathrm{C}$, indicando o conteúdo de água quimicamente combinada com os hidratos, ou seja, decomposição de C-S-H, gipsita e etringita; segunda faixa de $370{ }^{\circ} \mathrm{C}$ a $525{ }^{\circ} \mathrm{C}$, água quimicamente ligada com o hidróxido de cálcio; e terceira faixa de $525^{\circ} \mathrm{C}$ a $1000{ }^{\circ} \mathrm{C}$, dióxido de carbono ligado com o carbonato de cálcio. A Figura 10 mostra a análise termogravimétrica das séries de referência, submetidas ao ensaio AMBT e também a mantida em água destilada.

A Tabela 3 mostra os resultados da análise termogravimétrica de todas as amostras. Para as amostras contendo adições minerais, o teor de portlandita remanescente foi menor que para a amostra de referência. O consumo é relacionado à reação pozolânica, corroborando os resultados semelhantes observados por autores como Kandasamy e Shehata, 2014; Abbas et al., 2017; Medeiros et al., 2017 e Hoppe Filho et al., 2017.

Quando se compara as amostras imersas em água destilada com as amostras imersas na solução de $\mathrm{NaOH}$, é também observado um decréscimo na quantidade de portlandita remanescente. Como as condições de ensaio propiciam a aceleração da reação álcali-sílica, da mesma forma, elas aceleram a reação pozolânica (LINDGARD et al., 2012).

A reatividade do material, o tamanho médio das partículas e a quantidade adicionada ao cimento são características importantes que influenciam no desenvolvimento da reação pozolânica. Lindgard et al. (2012) apontam em sua revisão, que em altas temperaturas, adições com partículas mais finas tendem a acelerar a reação pozolânica. Se comparada a curva granulométrica e o tamanho médio das partículas da sílica ativa e da cinza de casca de arroz (Figura 1) é possível justificar um dos pontos de desempenho, que contribuíram para a adição de sílica ativa ser mais eficiente no processo de inibição da RAS. A cinza de casca de arroz apresenta $D_{50}$ aproximadamente 32 vezes maior que $\circ D_{50}$ apresentado pela sílica ativa.

É bem conhecido que partículas menores 

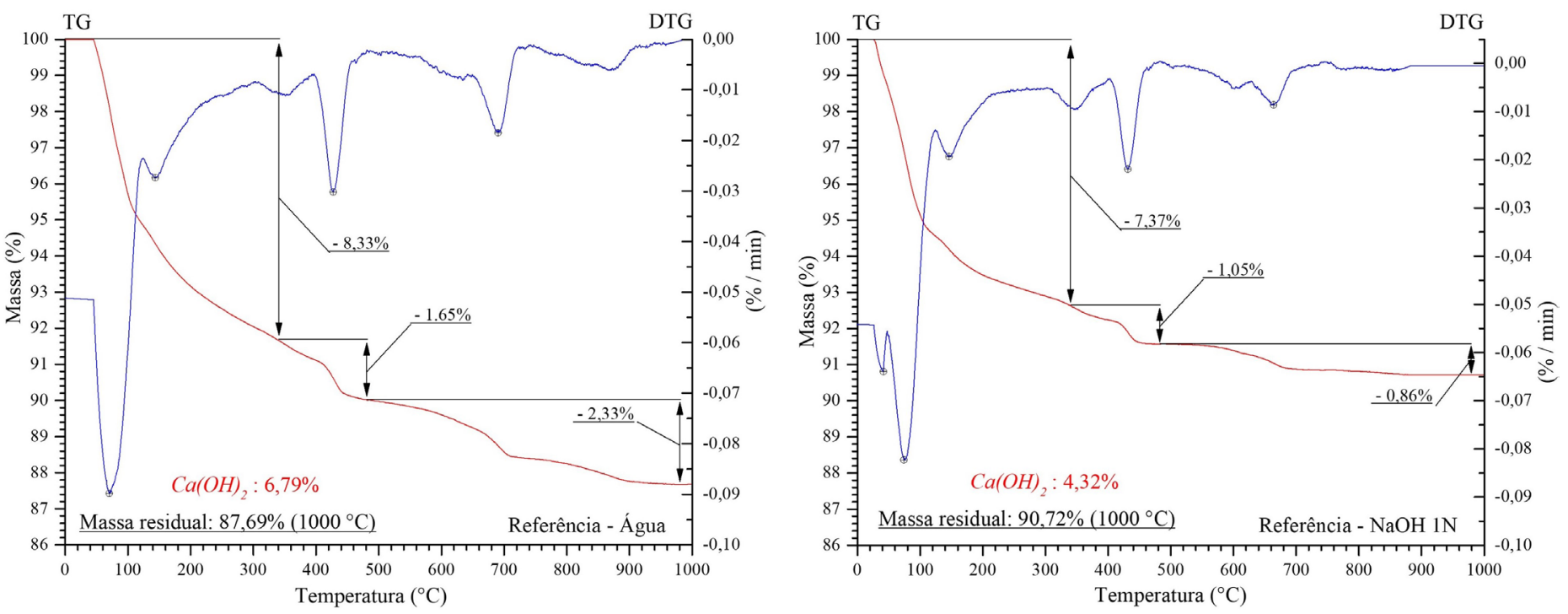

Fig. 10. TG e DTG das amostras de referência.

são capazes de reagir rapidamente devido à maior área de superfície, e isso tem importante influência no processo de hidratação e na cinética da RAS. Partículas CCA mais grossas diminuem a capacidade de empacotamento da mistura, levando a uma matriz ligeiramente mais porosa e permeável, facilitando a percolação de íons alcalinos. A moagem otimizada do material melhora as características pozolânicas aumentando a área superficial específica dos grãos (RÊGO et al., 2015). Segundo De Souza et al. (2000) as impurezas como compostos inorgânicos presentes na casca de arroz, não alteram significativamente a reação pozolânica, mas as partículas devem ter um tamanho pequeno na ordem de microns ou submicron. No mesmo contexto, Thanh et al. (2015), Ahsan e Hossain

Tabela 3. Análise termogravimétrica das amostras em água e submetidas ao ensaio AMBT.

\begin{tabular}{|c|c|c|c|c|c|}
\hline Amostra & $\begin{array}{c}\mathrm{C}-\mathrm{S}-\mathrm{H}+ \\
\text { aluminatos } \\
(\%)\end{array}$ & $\begin{array}{l}\mathrm{H}_{2} \mathrm{O} \\
(\%)\end{array}$ & $\begin{array}{c}\mathrm{Ca}(\mathrm{OH})_{2} \\
(\%)\end{array}$ & $\begin{array}{l}\mathrm{CO}_{2} \\
(\%)\end{array}$ & $\begin{array}{c}\mathrm{CaCO}_{3} \\
(\%)\end{array}$ \\
\hline $\begin{array}{l}\text { REF - } \\
\text { água }\end{array}$ & 8,33 & 1,65 & 6,79 & 2,33 & 5,30 \\
\hline $\begin{array}{l}\text { REF - } \\
\mathrm{NaOH}\end{array}$ & 7,37 & 1,05 & 4,32 & 0,86 & 1,95 \\
\hline $\begin{array}{l}\text { CCA - } \\
\text { água }\end{array}$ & 5,90 & 1,14 & 4,69 & 2,2 & 5,00 \\
\hline $\begin{array}{l}\mathrm{CCA}- \\
\mathrm{NaOH}\end{array}$ & 3,93 & 0,51 & 2,10 & 0,1 & 0,23 \\
\hline $\begin{array}{l}\text { SA - } \\
\text { água }\end{array}$ & 6,63 & 0,76 & 3,12 & 2,16 & 4,91 \\
\hline $\begin{array}{l}\mathrm{SA}- \\
\mathrm{NaOH}\end{array}$ & 3,51 & 0,09 & 0,37 & 0,32 & 0,73 \\
\hline
\end{tabular}

(2018) mostraram que as partículas de CCA mais finas são mais eficientes para mitigar a RAS do que as mais grossas. E quando se trata do AMBT, as condições do ensaio foram decisivas para o desempenho da adição mineral. Os resultados a seguir, de porosimetria por intrusão de mercúrio, serão úteis para ajudar a entender melhor esse comportamento.

\subsection{Porosimetria por intrusão de mercúrio}

A reação pozolânica não é o único ponto positivo do uso de adições para inibição da RAS. As adições minerais ativas podem contribuir para a redução da porosidade e permeabilidade de argamassas e concretos atuando também através do efeito físico, conhecido como efeito fíler. Esse efeito proporciona o refinamento dos poros da matriz, preenchimento de vazios com melhor empacotamento dos grãos além de contribuir para a nucleação heterogênea nos grãos de cimento (MOSER et al., 2010; AHSAN e HOSSAIN, 2018).

A reação álcali-sílica requer água para iniciar e, portanto, a redução na porosidade contribui para a mitigação do efeito da reação devido a alguns pontos importantes como a menor taxa de difusão de álcalis externos, diminuição da propagação de RAS e menor absorção de água pelo gel da RAS.

As condições agressivas do AMBT levam a considerar que as propriedades físicas das adições acabam tendo destaque no desempenho da 

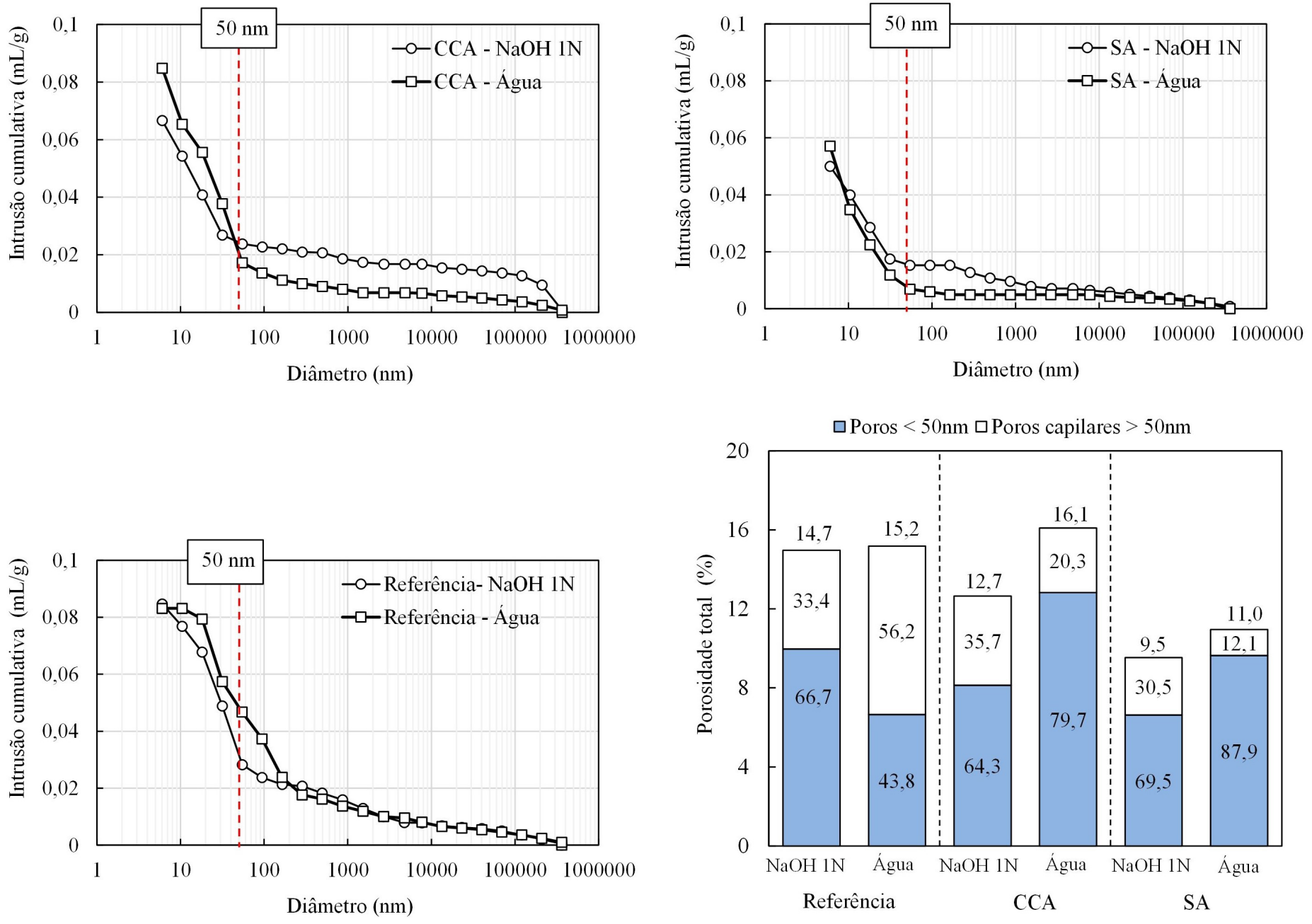

Fig. 11. Distribuição dos poros e porosidade total das amostras.

mesma frente a RAS, inclusive no desenvolvimento da reação pozolânica, como cita Lindgard et al. (2012).

A Figura 11 mostra a porosidade total e a distribuição do diâmetro de poros para todas as séries de argamassa, imersas na solução de $\mathrm{NaOH}$ a $(80 \pm 2){ }^{\circ} \mathrm{C}$ e também as imersas em água destilada e mantidas em temperatura ambiente (aproximadamente $24^{\circ} \mathrm{C}$ ).

É possível observar que a série de referência foi a única que apresentou um refinamento dos poros (poros menores que $50 \mathrm{~nm}$ ) quando as amostras foram submetidas ao ensaio AMBT. Observa-se também a redução da porosidade total quando, do mesmo modo que nas amostras contendo adição mineral. Isso pode ser justificado pela aceleração da hidratação do cimento devido as condições do ensaio.

Nas séries submetidas ao ensaio AMBT, as amostras com as adições apresentaram menor porosidade total e a partir desta porosidade e da observância da distribuição dos poros, a sílica ativa foi a adição que apresentou um maior refinamento dos poros da matriz. Se destacada a elevada temperatura do AMBT, é possível entender a aceleração da reação pozolânica nas barras com as adições. A porosidade total teve um decréscimo, porém na distribuição do diâmetro dos poros é possível obervar que o efeito químico foi rápido demais não proporcionando um refinamento dos poros. É notável o efeito da reação pozolânica nas amostras em água destilada, que apesar das amostras apresentarem uma porosidade total um pouco mais elevada, houve um refinamento dos poros notável em ambas as argamassas com adições minerais.

Além da menor porosidade, a argamassa com substituição parcial do cimento por sílica ativa apresentou também o menor coeficiente de permeabilidade (Figura 12). 


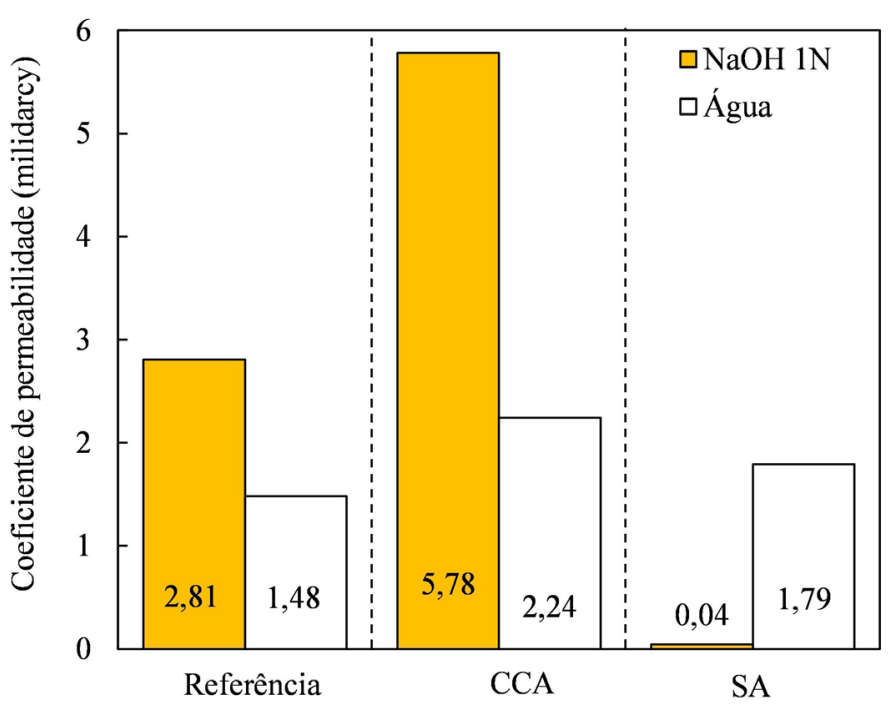

Fig. 12. Permeabilidade das argamassas.

Os resultados obtidos para a sílica ativa corroboram com os resultados dos demais testes, mostrando menor coeficiente de permeabilidade, menor porosidade total e menor expansão das barras de argamassa (AMBT).

A argamassa contendo CCA apresentou um coeficiente de permeabilidade maior que os demais (ou seja, SA e referência). A cinza de casca de arroz foi capaz de reduzir a porosidade total quando submetida ao teste (comparando a série em água destilada), principalmente devido a aceleração da reação pozolânica. Os produtos secundários formados com a reação pozolânica ajudam a preencher alguns vazios e o espaçamento interpartículas, o que explica a menor porosidade. Mas, mesmo considerando a reatividade e a formação do C-S-Hpozolânico, a cinza de casca de arroz não foi capaz de acessar totalmente os vazios mais finos e reduzir a permeabilidade das barras de argamassa. A distribuição dos diâmetros dos poros mostrou que $66,7 \%$ dos poros das amostras de referência foram menores que $50 \mathrm{~nm}$ (microporos), enquanto na argamassa com sílica ativa foi de $69,5 \%$ e com cinza de casca de arroz foi de $64,3 \%$ dos poros.

Ahsan e Hossain (2018) observaram que cinzas de casca de arroz com partículas mais grossas contribuíram significativamente na expansão devido a RAS. As partículas grossas criam uma distância entre elas devido a uma não homogeneização na mistura o que contribui para o ingresso de agentes externos, no caso da solução de $\mathrm{NaOH}$, e água.

Já a sílica ativa foi capaz de alterar significativamente a microestrutura das argamassas devido a sua morfologia, composição química e reatividade, considerando essencialmente a avaliação de curto prazo do ensaio, como o teste acelerado de barras de argamassa. Os resultados para a expansão induzida foram significativamente diferentes o que pode indicar que as propriedades químicas e principalmente físicas (granulometria) das adições minerais ativas são importantes no controle da cinética da RAS para a avaliação de curto prazo em ambiente agressivo, como é o caso do AMBT. Além disso, é necessário considerar que o ensaio AMBT pôde não proporcionar condições ideais para o desenvolvimento da reação pozolânica uma vez que existe uma fonte inesgotável de álcalis e, portanto, as adições minerais não devem ser descartadas apenas a partir dos resultados obtidos por este teste. Testes em concreto e em campo devem ser considerados.

\section{Conclusões}

Este trabalho experimental permite estabelecer as conclusões a seguir:

O efeito da elevada temperatura e da solução de $\mathrm{NaOH}$ no desenvolvimento da reação pozolânica, refinamento dos poros e redução da permeabilidade das argamassas por parte das adições minerais ativas, pôde ser observado.

Os resultados de expansão mostraram que as argamassas com sílica ativa e com a cinza de casca de arroz foram capazes de diminuir a taxa de expansão da RAS, em comparação com as amostras de referência. O ensaio pelo método acelerado demonstrou que a adição de $10 \%$ de sílica ativa como substituição parcial do cimento foi a opção mais efetiva em mitigar a reação álcali-sílica. A minimização da expansão está relacionada à redução do teor de hidróxido de cálcio na argamassa, corroborando com a maior atividade pozolânica apresentada pela sílica ativa no ensaio Chapelle modificado.A porosidade e a permeabilidade das amostras estão relacionadas diretamente com a finura das partículas, seja pela ação física 
de empacotamento, como pela ação química de atividade pozolânica, desta forma, a maior área de superfície influência no processo de hidratação e na cinética das reações. Consequentemente, partículas mais grossas diminuem a capacidade de empacotamento da mistura, levando a uma matriz ligeiramente mais porosa e permeável, conforme observado na comparação entre as amostras.

O AMBT não proporcionou conclusões exatas sobre o uso da cinza de casca de arroz como material inibidor da RAS para uso em conjunto do cimento. As propriedades físicas do material, como granulometria e diâmetro médio das partículas foram primordiais no desempenho dessa adição frente a reação deletéria no teste acelerado, necessitando de testes específicos para cada caso de aplicação.

Outros estudos são propostos com a cinza de casca de arroz, principalmente testes em concreto, visto que há poucas pesquisas ainda na literatura com o uso desse material e muitas são contraditórias. Não se deve descartar o uso de um potencial material com base em apenas um ensaio acelerado. Entender os mecanismos por trás do teste são necessários para classificar uma adição como potencial inibidora da reação álcali-sílica.

\section{Agradecimentos}

Os autores agradecem ao Programa de PósGraduação em Engenharia de Construção Civil da Universidade Federal do Paraná e o suporte financeiro promovido pela CAPES (Coordenação de Aperfeiçoamento de Pessoal de Nível Superior).

\section{Referências Bibliográficas}

ABBAS, S.; KAZMI, S. M. S.; MUNIR, M. J. Potential of rice husk ash for mitigating the alkali-silica reaction in mortar bars incorporating reactive aggregates. Construction and Building Materials, v. 132, p. 61-70, 2017.

AHSAN, M. B.; HOSSAIN, Z. Supplemental use of rice husk ash (RHA) as a cementitious material in concrete industry. Construction and Building
Materials, v. 178, p. 1-9, 2018.

ALAEJOS, P.; LANZA, V.; BERMÚDEZ, M. A.; VELASCO, A. Effectiveness of the accelerated mortar bar test to detect rapid reactive aggregates (including their pessimum content) and slowly reactive aggregates. Cement and Concrete Research, v. 58, p. 13-19, 2014

AMERICAN SOCIETY FOR TESTING AND MATERIALS. ASTM C150, Standard Specification for Portland Cement, ASTM International, West Conshohocken, PA, 2020.

AMERICAN SOCIETY FOR TESTING AND MATERIALS. ASTM C294, Standard Descriptive Nomenclature for Constituents of Concrete Aggregates, ASTM International, West Conshohocken, PA, 2019.

AMERICAN SOCIETY FOR TESTING AND MATERIALS. ASTM C1260-14, Standard Test Method for Potential Alkali Reactivity of Aggregates (Mortar-Bar Method), ASTM International, West Conshohocken, PA, 2014.

AQUINO, W.; LANGE, D.; OLEK, J. The influence of metakaolin and silica fume on the chemistry of alkali-silica reaction products. Cement and Concrete Composites, v. 23, n. 6, p. 485-493, 2001.

ASOCIACIÓN ESPAÑOLA DE NORMALIZACIÓN Y CERTIFICACIÓN. UNE-EN 197-1, Cementos comunes: deficiones, denominaciones, classificacción y especificaciones de los mismos. 2011.

ASOCIACIÓN ESPAÑOLA DE NORMALIZACIÓN Y CERTIFICACIÓN. UNE 146508, Determinación de la reactividad potencial álcali-sílice y álcali-silicato de los áridos. Método acelerado en probetas de mortero. 2018.

ASSOCIAÇÃO BRASILEIRA DE NORMAS TÉCNICAS. ABNT NBR 15895-10, Materiais pozolânicos Determinação do teor de hidróxido de cálcio fixado - Método Chapelle modificado. Rio de Janeiro: ABNT, 2010.

ASSOCIAÇÃO BRASILEIRA DE NORMAS TÉCNICAS. 
ABNT NBR 15577-1: Agregados - Reatividade álcali-agregado Parte 1: Guia para avaliação da reatividade potencial e medidas preventivas para uso de agregados em concreto. Rio de Janeiro: ABNT, 2018.

ASSOCIAÇÃO BRASILEIRA DE NORMAS TÉCNICAS. ABNT NBR 15577-4: Agregados - Reatividade álcaliagregado Parte 4: Determinação da expansão em barras de argamassa pelo método acelerado. Rio de Janeiro: ABNT, 2018.

ASSOCIAÇÃO BRASILEIRA DE NORMAS TÉCNICAS. ABNT NBR 15577-5: Agregados - Reatividade álcaliagregado Parte 5: Determinação da mitigação da expansão em barras de argamassa pelo método acelerado. Rio de Janeiro: ABNT, 2018.

BROEKMANS, M. A. T. M. Deleterious reactions of aggregate with alkalis in concrete. Reviews in Mineralogy and Geochemistry, v. 74, n. 1, p. 279364, 2012.

Canadian Standards Association. CAN/CSA-A23.225A-14, Test method for detection of alkali-silica reactive aggregate by accelerated expansion of mortar bars. 2014.

CONSTANTINER, D.; DIAMOND, S. Alkali release from feldspars into pore solutions. Cement and Concrete Research, v. 33, n. 4, p. 549-554, 2003.

CORDEIRO, G. C. et al. Influence of particle size and specific surface area on the pozzolanic activity of residual rice husk ash. Cement and Concrete Composites, v. 33, n. 5, p. 529-534, 2011.

DESCHENES, R. A.; MICAH HALE, W. AlkaliSilica Reaction in Concrete with Previously Inert Aggregates. Journal of Performance of Constructed Facilities, v. 31, n. 2, p. 04016084 , 2017.

FOURNIER, B.; BÉRUBÉ, M.-A. Alkali-aggregate reaction in concrete: a review of basic concepts and engineering implications. Canadian Journal of Civil Engineering, v. 27, n. 2, p. 167-191, 2000.
FOURNIER,B. et al. Evaluating Potential AlkaliReactivity of Concrete Aggregates - How Reliable are the Current and New Test Methods? In: II SYMPOSIUM ON ALKALI-AGGREGATE REACTION IN CONCRETE STRUCTURES, 2006. Rio de Janeiro. Anais [...]. São Paulo: IBRACON, 2006

GOLMAKANI, F.; HOOTON, R. D. Comparison of laboratory performance tests used to assess alkalisilica reactivity. Proceedings, Annual Conference Canadian Society for Civil Engineering, v. 2, p. 1-7, 2016.

HASPARYK, N. P.; MONTEIRO, P. J. M.; CARASEK, H. Effect of Silica Fume and Rice Husk Ash on AlkaliSilica Reaction. ACI Materials Journal, n. 97, 2001.

HOPPE FILHO, J. et al. Reactivity assessment of residual rice-husk ashes. Journal of Materials in Civil Engineering, v. 29, n. 6, p. 04017003, 2017

KANDASAMY, S.; SHEHATA, M. H. The capacity of ternary blends containing slag and high-calcium fly ash to mitigate alkali silica reaction. Cement and Concrete Composites, v. 49, p. 92-99, 2014.

KATZ, A. J.; THOMPSON, A. H. Quantitative prediction of permeability in porous rock. Physical Review B, v. 34, n. 11, p. 8179-8181, 1986.

LATIFEE, E. R.; RANGARAJU, P. R. Miniature concrete prism test: Rapid test method for evaluating alkalisilica reactivity of aggregates. Journal of Materials in Civil Engineering, v. 27, n. 7, 2015.

LINDGARD, J. et al. Alkali-silica reactions (ASR): Literature review on parameters influencing laboratory performance testing. Cement and Concrete Research, v. 42, n. 2, p. 223-243, 2012.

LNEC E 461. Betões. Metodologia para prevenir reacções expansivas internas, 2007. Lisboa.

LOCATI, F.; MARFIL, S.; BALDO, E. Effect of ductile deformation of quartz-bearing rocks on the alkalisilica reaction. Engineering Geology, v. 116, n. 1, p. 117-128, 2010. 
MEDEIROS, M. H. F. DE; RAISDORFER, J. W.; HOPPE FILHO, J. Influência da sílica ativa e do metacaulim na velocidade de carbonatação do concreto: relação com resistência, absorção e relação a/c. Ambiente Construído, v. 17, n. 4, p. 125-139, 2017.

MEDEIROS, M. H. F. DE; RAISDORFER, J. W.; HOPPE FILHO, J.; MEDEIROS-JUNIOR, R. A. Partial replacement and addition of fly ash in Portland cement: influences on carbonation and alkaline reserve. Journal of Building Pathology and Rehabilitation, v. 2, n. 1, p. 4, 2017.

QUARCIONI, V. A.; CHOTOLI, F. F.; COELHO, A. C. V.; CINCOTTO, M. A. Indirect and direct Chapelle's methods for the determination of lime consumption in pozzolanic materials. IBRACON Structures and Materials Journal, v. 8, n. 1, p. 1-7, 2015.

RÊGO, J. H. S.; NEPOMUCENO, A. A.; FIGUEIREDO, E. P.; HASPARYK, N. P. Microstructure of cement pastes with residual rice husk ash of low amorphous silica content. Construction and Building Materials, v. 80, p. 56-68, 2015.

SHEHATA, M. H.; THOMAS, M. D. A. The effect of fly ash composition on the expansionof concrete due to alkali-silica reaction. Cement and Concrete Research, v. 30, n. 7,p. 1063-1072, 2000

DE SOUZA, M. F. et al. al. al. Rice hull-derived silica: applications in Portland cement and mullite whiskers. Materials Research, v. 3, n. 2, p. 25-30, 2000.

THANH, H.; SIEWERT, K.; LUDWIG, H. Alkali silica reaction in mortar formulated from self-compacting high performance concrete containing rice husk ash. Construction and Building Materials, v. 88, p. 10-19, 2015.

THOMAS, M. The effect of supplementary cementing materials on alkali-silica reaction: A review. Cement and Concrete Research, v. 41, n. 12, p. 1224-1231, 2011. evaluating supplementary cementing materials using accelerated mortar bar test. ACI Materials Journal, v. 104, n. 2, p. 115-122, 2007.

THOMAS, M. D. A.; FOLLIARD, K. J. Concrete aggregates and the durability of concrete. C.L. Page, M.M. Page (Eds.), Durability of concrete and cement composites, Woodhead, Cambridge, U.K, p. 247-281, 2007.

THOMAS, M.; DUNSTER, A.; NIXON, P.; BLACKWELL, $B$. Effect of fly ash on the expansion of concrete due to alkali-silica reaction - Exposure site studies. Cement and Concrete Composites, v. 33, n. 3, p. 359-367, 2011.

THOMAS, M. et al. Test methods for evaluating preventive measures for controlling expansion due to alkali-silica reaction in concrete. Cement and Concrete Research, v. 36, n. 10, p. 1842-1856, 2006.

VALDUGA, L. Influência das condições de ensaio da ASTM C 1260 na verificação da reação álcaliagregado. 204 f. Tese (Doutorado em Engenharia Civil) - Universidade Federal do Rio Grande do Sul, 2007 


\section{Autoconstrução e autogestão habitacional no Brasil: um estudo comparativo em dois períodos: 1975-1986 e 2004-2018}

Marina B. Ferreiraa,*

${ }^{\text {a}}$ Programa de pós-graduação em Urbanismo, PROURB, Universidade Federal do Rio de Janeiro, Rio de Janeiro/Brasil

\section{Informações}

Recebido 2 Outubro 2020

Manuscrito revisado recebido 8 Novembro 2020

Aceito 10 Novembro 2020

Palavras-chave

Autoconstrução

Ajuda mútua

Programas alternativos

MCMV-e.

\section{Resumo}

As políticas habitacionais direcionadas à população de baixa renda ocupam um importante espaço na agenda técnico-político da maioria dos países, sendo muitas vezes, vinculadas a práticas de ajuda mútua, autoconstrução, mutirão e autogestão. O presente artigo analisa dois períodos em que, no Brasil, essas práticas foram apoiadas e institucionalizadas a nível federal: o primeiro, entre 1975 1986, por meio dos denominados Programas Alternativos implementados pelo Banco Nacional de Habitação (BNH), e o segundo, entre 2004 - 2018, com os programas Crédito Solidário e Minha Casa Minha Vida - Entidades (MCMV-e). O estudo apresenta a relação entre esses dois períodos históricos evidenciando seus contrastes no que tange o incentivo à políticas habitacionais de fomento à autoconstrução no Brasil. A partir do estudo comparativo, percebe-se a oscilação no diálogo entre Estado e sociedade civil, bem como a forma distinta com que as noções presentes no debate são apropriadas pelos diferentes grupos sociais.

\section{Self-construction and Self-Management in Brazil. A comparative study in two periods: 1975- 1986 and 2004-2018}

\section{Article info}

Received 2 October 2020

Received in revised form 8 November 2020

Accepted 10 November 2020

\section{Keywords}

Self-construction

Mutual help

Alternative programs MCMV-e

\section{Abstract}

Housing policies aimed at the low-income population occupy an important place on the technicalpolitical agenda of most countries, and are often linked to practices of mutual aid, self-construction, collective effort and self-management. This article analyzes two periods in which, in Brazil, these practices were supported and institutionalized at the federal level: the first, between 1975 - 1986, through the so-called Alternative Programs implemented by the National Housing Bank (NHB), and the second, between 2004 - 2018, with the Crédito Solidário and Minha Casa Minha Vida - Entities (MCMV-e) programs. The study presents the relationship between these two historical periods, highlighting their contrasts in terms of encouraging housing policies to promote self-construction in Brazil. From the comparative study, there is an oscillation in the dialogue between the State and civil society, as well as the different way in which the notions present in the debate are appropriated by different social groups.

\section{Autoconstrucción y Autogestión en Brasil. Estudio comparativo en dos periodos: 1975-1986 y 2004-2018}

\section{Información}

Recibido 2 Octubre 2020

Manuscrito revisado recibido 8 Noviembre 2020

Aceptado 10 Noviembre 2020

\section{Palabras clave} Autoconstrucción Ayuda mútua Programas alternativos MCMV-e.

\section{Resumen}

Las políticas habitacionales dirigidas a la población de bajos ingresos ocupan un lugar importante en la agenda técnico-política de la mayoría de los países, y muchas veces están vinculadas a prácticas de ayuda mutua, autoconstrucción, esfuerzo colectivo y autogestión. Este artículo analiza dos períodos en los que, en Brasil, estas prácticas fueron apoyadas e institucionalizadas a nivel federal: el primero, entre 1975 - 1986, a través de los denominados Programas Alternativos implementados por el Banco Nacional de la Vivienda (BNH), y el segundo, entre 2004 - 2018, con los programas Crédito Solidário y Minha Casa Minha Vida - Entidades (MCMV-e). El estudio presenta la relación entre estos dos períodos históricos, destacando sus contrastes en términos de incentivar políticas habitacionales para promover la autoconstrucción en Brasil. A partir del estudio comparado, se observa una oscilación en el diálogo entre el Estado y la sociedad civil, así como la diferente forma en que las nociones presentes en el debate son apropiadas por diferentes grupos sociales.

\footnotetext{
* Autor correspondente em: Programa de pós-graduação em Urbanismo, PROURB, Universidade Federal do Rio de Janeiro, Rio de Janeiro/Brasil. E-mail: marina.boarettof@gmail.com (Marina B. Ferreira)
} 


\section{Introdução}

A predominância da dinâmica capitalista no contexto mundial nos leva a refletir sobre o poder de dominação desse sistema e as condições necessárias a sua sobrevivência. Um olhar atento frente aos acontecimentos atuais, apoiados na expansão do fenômeno da g lobalização, nos avanços científicos e tecnológicos e no aprofundamento das desigualdades sociais, confirma que vivemos em um momento complexo de tendências contraditórias.

Por um lado, o sistema capitalista se reinventa e se reconfigura. Novas formas de dominação são estabelecidas, cada vez mais abstratas, impulsionando processos de acumulação de capital. Por outro lado, processos sociais e políticos emergem e lutam contra ameaças e impactos do capitalismo e da globalização econômica. Alavancados por um conjunto de grupos sociais articulados, esses esforços buscam o reconhecimento, a defesa e a realização dos direitos humanos, lutando contra as formas de dominação, discriminação e exploração.

Essas contradições ganham expressão no campo da produção habitacional popular onde grupos de moradores, movimentos sociais de base, organizações sem fins lucrativos, cooperativas entre outros agentes se organizam a fim de reivindicar seus direitos como cidadãos capazes de construir, gerir e redefinir o espaço comum, construindo coletivamente soluções cujas principais estratégias partem de processos de auto-organização, democratização, participação ativa e autonomia. Dessa forma, a produção habitacional se apresenta como um campo em disputa, sendo os processos de formulação e implementação das políticas e programas habitacionais reflexos dessas tensões.

Esse artigo busca retratar essas disputas em dois momentos históricos: no primeiro, período de ditadura militar onde as políticas habitacionais de ajuda mútua são formuladas e oferecidas pelo Estado sem o envolvimento da sociedade civil; e n segundo período, onde há maior abertura de diálogo entre Estado e sociedade civil, em especial com os movimentos populares, ampliando a participação desses grupos na formulação de políticas e programas habitacionais.

\section{Autoconstrução Habitacional e Políticas de Ajuda Mútua}

\subsection{Autoconstrução habitacional como prática social}

\begin{abstract}
"A autoconstrução, o mutirão, a auto-ajuda, a ajuda mútua são termos usados para designar um processo de trabalho calcado na cooperação entre as pessoas, na troca de favores, nos compromissos familiares, diferenciando-se portanto das relações capitalistas de compra e venda da força de trabalho." (MARICATO, 1979, p. 71).
\end{abstract}

Inicialmente é importante reconhecer a autoconstrução habitacional como uma prática antiga e não como uma idéia inovadora do século XX. No contexto capitalista da sociedade atual, a autoconstrução aparece como uma estratégia de construção para uma ampla parcela da população que, desprovida de condições de acesso à moradia por meio do mercado formal, resolve sua necessidade por conta própria, providenciando diretamente a construção e gestão de suas casas.

A prática da autoconstrução deve ser compreendida como um conjunto de atividades relacionadas à construção, e não somente a construção física da unidade habitacional. A casa autoconstruída deve "ser edificada sob gerência direta do seu proprietário e morador: adquire ou ocupa o terreno; traça, sem apoio técnico, um esquema de construção; viabiliza a obtenção dos materiais; agencia a mão de obra, gratuita e/ou remunerada informalmente; e constrói sua casa." (BONDUKI, 1994, p. 258).

"O tema auto construção parte de um certo pressuposto de que a população só constrói, o que não é verdade apenas do ponto de vista físico, se colocar bloco sobre bloco e se fizer revestimentos etc. Embute a ideia de empreendimento porque é preciso arranjar um terreno para construir, épreciso mobilizar algum tipo de arranjo financeiro para comprar 0 material a prestação e para estocá-lo ao longo do tempo quando não há o financiamento, até ter todo o material comprado poder fazer um novo ciclo de construção, uma 
vez que as moradias construídas desta maneira são feitas em soluços, digamos assim. [...] Além do arranjo de mão de obra, pois a idéia de que apenas a mão de obra é do próprio morador ou da sua família é um pouco romântica dos anos 60 e 70. Na verdade esses arranjos envolvem contratação de pedreiros avulsos e de algum tipo de apoio de mão de obra especializada. Ou seja, existe um arranjo de mão de obra para o processo de produção. Neste contexto, há uma ideia de empreendimento com um conjunto de atores e fatores que atuam neste processo de produção da unidade habitacional [....".(BONDUKI, 2017, Palestra no (AU-RJ).

No campo habitacional, o termo "autoconstrução" pode assumir distintas conotações, a saber: não significa necessariamente autoconstruído ou autogerido; tem sido utilizado para caracterizar tanto esforços individuais como coletivos (mutirão); possui relação com o processo de construção da habitação de forma progressiva, em etapas, de forma incremental; está associado à um processo de construção que ocorre espontaneamente na maior parte do mundo; e, finalmente o termo é amplamente usado de forma normativa, empregado para prescrever um conjunto de políticas habitacionais pelas agências internacionais, governos centrais e demais órgãos de formulação de políticas.

\subsection{Autoconstrução habitacional como política pública}

\footnotetext{
"Entende-se a autoconstrução como política pública as propostas que colocam o Estado e o usuário em uma "ação em conjunto" em uma espécie de plataforma comum de intervenção. Nesta "parceria" se unem dois agentes que, em geral, representam interesses antagônicos e conflitantes: o Estado, expressão da oferta institucionalizada de moradias e o usuário, expressão da demanda de moradias." (ROSSETO, 1994, p.9).
}

As políticas de autoconstrução estão ancoradas em programas e projetos governamentais que induzem e promovem a prática da autoconstrução.
Nesse contexto o morador é incorporado ainda na fase de construção da habitação, se tornando co-autor do processo de provisão. Em geral, se configuram por meio de três tipos de programas: oferta de lotes urbanizados, dotados ou não de unidade sanitária ou unidade embrião; oferta de materiais de construção; e oferta de assistência técnica para o processo de construção.

As políticas de autoconstrução podem ser desenvolvidas de diversas maneiras, de acordo com o grau de participação e responsabilidades assumidas por diferentes grupos de atores: governo, instituições habitacionais, movimentos sociais, futuros usuários etc. Os programas e projetos podem contemplar, desde uma pequena participação do Estado, como no caso dos esquemas de "lotes e serviços" em que é oferecido apenas o financiamento de um terreno provido de infra-estrutura básica, até uma maior participação, onde para além do financiamento do terreno e da provisão de infra-estrutura, o Estado se responsabiliza pela viabilização de créditos para compra de materiais de construção e assistência técnica adequada durante todo o processo.

Para além da distribuição de responsabilidades entre os grupos envolvidos, os programas de apoio à autoconstrução assumem diferentes configurações de acordo com: a forma como o processo é conduzido, se de forma individual ou coletiva, se o grupo de moradores foi previamente organizado ou não; a existência ou não subsídios diretos e/ou indiretos; o grau de autonomia e poder de decisão dos moradores no processo; o padrão de assessoria técnica, político, pedagógica e social; etc.

Assim, trata-se de um complexo arranjo de atividades e atores, onde cada caso representa possibilidades e limitações singulares que, desencadeiam, consequentemente, processos diferenciados.

\subsection{Origens e perspectivas sobre as Políticas Habitacionais de Ajuda Mútua}

As origens das políticas de autoconstrução institucionalizada são atribuídas por diferentes 
autores a momentos distintos da história, não havendo consenso quanto a essa questão. Grande parte destes refere suas origens entre as década de 1960 e 1970, devido ao destaque que estas políticas tiveram no período, embasadas nas teorias do arquiteto inglês John F. C. Turner e nos projetos de lotes e serviços financiados pelo Banco Mundial.

Outros autores, como Richard Harris e Ray Bromley, assumem suas origens a períodos anteriores às formulações de John Turner, reconhecendo como importante contribuição as formulações de autores como Charles Abrams (1964, 1966), William Mangin (1967) e Aprodicio Lacquian (1971).

No estudo desenvolvido por Richard Harris (1998), foram identificadas diversas iniciativas implementadas anteriores à década de 1960. Segundo o autor, a ideia de que os governos poderiam ajudar famílias a construir suas próprias casas teria surgido por etapas: primeiramente, foi uma política decretada pelo governo suíço, em 1904, seguido por programas desenvolvidos pela Europa e União Soviética após a Primeira Guerra Mundial, representando uma resposta pragmática e não teorizada à grave escassez de habitação e agitação política enfrentada nesse período (HARRIS, 1998) ${ }^{1}$.

Na década de 1930, as políticas de autoconstrução institucionalizadas foram incorporadas de forma mais padronizada nas políticas de bem estar social, tanto na Europa como nos EUA, alcançando proeminência no debate público.

Durante a década de 1940, essas políticas foram implementada em Porto Rico pelo Governo dos Estados Unidos e seguido por outros países do Caribe, nos anos subsequentes. Outras nações latino-americanas, como Colômbia e Peru, além de várias colônias e ex-colônias britânicas, como Gold Coast (atualmente parte de Gana), Quênia, África do Sul e Índia, também adotaram programas de autoconstrução institucionalizada neste período (HARRIS, 1999).

$\mathrm{Na}$ década de 1950, foram realizadas experiências-piloto na Costa Rica, Chile, Guatemala, 1 Ver artigos de Richard Harris sobre as origens das políticas de autoconstrução institucionalizadas: "Slipping through the Cracks: The Origins of Aided Self-help Housing, 1918-53"; e "The silence of the experts: "Aided self-help housing", 1939-1954".
Nicarágua e Panamá (ROSSETO, 1994). A partir dessa década, os programas de autoconstrução institucionalizada começaram a ser identificados como solução para o problema da habitação para os pobres urbanos dos países em desenvolvimento. No final dos anos 1950 e início dos anos 1960, o Banco Interamericano de Desenvolvimento - BID, por meio do Programa Aliança para o Progresso, passou a financiar projetos habitacionais, incluindo projetos com base na autoconstrução além da construção de grandes conjuntos habitacionais.

Na década de 1960, as iniciativas do Estado para responder à crise habitacional eram baseadas, principalmente: 1. na construção de conjuntos habitacionais de larga escala, implementados nas franjas dos centros urbanos; 2. na política de erradicação das favelas e assentamentos, onde a prática de remoções era usual; 3. e na ausência de participação dos futuros moradores nos processos de produção da habitação.

Diante dessa conjuntura, intensificou-se um movimento crítico em relação aos grandes conjuntos habitacionais, principalmente por serem: inacessíveis às camadas mais pobres da população; 2. localizados longe de oportunidades tanto sociais quanto econômicas; 3. uma solução genérica, replicável, sem particularidades; 4. desenvolvidos sem a participação dos futuros moradores.

A frente deste movimento crítico estava o arquiteto inglês John F. C. Turner (1963, 1965, 1967, 1968a, 1969, 1972, 1976), que inspirado na capacidade de organização e construção dos moradores nos assentamentos urbanos na América Latina, defendeu a prática da autoconstrução realizada pelos pobres alegando ser mais rentável e apropriada para as necessidades e valores dessas pessoas. Segundo Turner, os esquemas de provisão habitacional pelo Estado eram caros, ineficientes e inadequados às necessidades da população.

O arquiteto, defendia que o Estado deveria desempenhar um papel de apoio, fornecendo aos grupos de baixa renda acesso aos recursos como terra, materiais e finanças (TURNER, 1968; 1972; 1976). 
“...o que estou defendendo é uma mudança radical na relação entre as pessoas e o governo, na qual o governo deixa de persistir em fazer o que faz mal ou de forma nãoeconômica - construir e gerenciar casas - e concentra-se no que tem autoridade para fazer: garantir acesso equitativo aos recursos que as comunidades locais e as pessoas não podem prover para si mesmas." (TURNER, 1976, p. 14).

Em sua visão, os assentamentos construídos pela população - "invasores" - com seus próprios esforços eram melhor adaptados às suas necessidades e circunstâncias em contraposição àqueles projetados pelo governo, onde as unidades habitacionais geralmente não atendiam às demandas e às diversas necessidades e prioridades culturais, sociais e econômicas a que se pretendiam.

O arquiteto sustentava a ideia de que as habitações deveriam ser produzidas de acordo com seu "valor de uso" - segundo definições do próprio morador de acordo com suas necessidades - e não pelo seu "valor de troca" no mercado (TURNER, 1972).

Alguns dos principais conceitos elaborados por Turner, desenvolvidos em suas publicações "Arquitetura da democracia" em 1967, "Habitação por pessoas" em 1976, "Liberdade para construir", "Habitação como um verbo" em 1972 - foram amplamente propagados, sendo o autor uma grande referência no campo da habitação social até os dias atuais.

Os argumentos influentes de Turner - baseados nos princípios de ajuda mútua - legitimaram uma mudança na política do Banco Mundial na década de 1970 e serviram como diretrizes para a construção do modelo de lotes urbanizados. A defesa da função do Estado como agente facilitador pode ser evidenciada na citação do Banco Mundial abaixo:

"Um Estado eficiente é vital para a provisão de bens, de serviços, de normas e instituições, que permitam que os mercados floresçam e que as pessoas tenham uma vida mais saudável e feliz. [...] Há cinqüenta anos a tendência era dar a entender que competia ao Estado a provisão do desenvolvimento. A nova mensagem é diferente: o Estado é essencial para o desenvolvimento econômico e social, não como promotor direto do crescimento, mas como parceiro, catalisador e facilitador." (WORLD BANK, 1997, p. 1).

Segundo Richard Harris, Turner conseguiu mudar a percepção do mundo sobre os programas de habitação por ajuda mútua como um meio alternativo de provisão habitacional de baixa renda. Dessa forma, os programas com base na autoconstrução ganharam destaque entre governos e instituições como um modelo de provisão habitacional alternativo à autoconstrução espontânea e aos esquemas estatais de construção de conjuntos habitacionais.

Em contrapartida, alguns autores como Rod Burgess $(1978,1985,1987)$, Mike Davis (2004), Emilio Pradilla (1976, 1983), Francisco de Oliveira (2006), Sérgio Ferro (2006) evidenciaram contradições e limitações presentes na abordagem da institucionalização da autoconstrução, destacando que num contexto de uma sociedade capitalista, essa prática representaria um mecanismo injusto do governo para economizar custos ao explorar as famílias pobres, inferindo um caráter exploratório sobre o trabalhador que precisa fazer horas extras de trabalho (não remuneradas) para ter acesso ao serviço habitação.

"Uma não insignificante porcentagem das residências das classes trabalhadoras foi construida pelos próprios proprietários, utilizando dias de folga, fins de semana e formas de cooperação como o 'mutirão'. Ora, a habitação, bem resultante dessa operação, se produz por trabalho não pago, isto é, supertrabalho." (OLIVEIRA, 2006, p. 59).

As habitações autoconstruídas tendem a ser mais baratas do que as fornecidas pelo Estado devido a diminuição de agentes intermediários e na redução dos custos em relação à mão de obra. Segundo esses autores, essa redução do custo da habitação contribui para a redução do valor do 
salário mínimo, já que o salário mínimo inclui o valor da habitação em seu cálculo, "desse modo, o homem autoconstrói porque ganha mal e, pelo fato de autoconstruir, seu salário é rebaixado." (BALTHAZAR, 2012, p. 58).

Esses autores, críticos à adoção da prática da autoconstrução como política pública, também consideram que a autoconstrução quando institucionalizada leva à redução do grau de responsabilidade do Estado em relação à produção habitacional, deixando o Estado de assumir o papel de provedor principal para atuar apenas como agente facilitador do processo de provisão habitacional.

Há ainda um grupo de autores tais como Nabil Bonduki, Ermínia Maricato, João Marcos Lopes, Peter Marcuse, Erhard Berner, Benedict Phillips, Jorge Fiori, Ronaldo Ramirez e Kosta Mathéy, que apoiam as políticas que se utilizam da autoconstrução, porém referem ressalvas. Consideram a questão habitacional como um problema macroestrutural mas identificam no modelo de autoconstrução institucionalizada um meio possível para redistribuição de riqueza.

Esses autores alertam que as abordagens de autoconstrução com base na recuperação total dos custos necessariamente excluem os grupos mais pobres e ampliam as desigualdades estruturais. Nesta linha de pensamento, ressaltam a necessidade das iniciativas de autoconstrução institucionalizada serem acompanhadas da oferta de assessoria técnica adequada e contínua onde seja garantida a participação efetiva das famílias.

Esses autores veem na autoconstrução institucionalizada, em contextos políticos específicos, especialmente sob processos autogestionados e coletivos, uma forma de estimular a construção de sujeitos políticos e a organização popular na defesa de seus interesses.

Assim, verificamos três principais correntes de pensamento quanto à produção habitacional baseada na autoconstrução institucionalizada: aqueles que são a favor do esquema por ajuda mútua, aqueles que são contra, e aqueles que apoiam dentro de certas condições. Vale ressaltar que essas correntes não se limitam a esses três grupos, e nem esses grupos conformam uma linha de pensamento concisa, uniforme e fechada.

Dessa forma, observa-se que o debate sobre a autoconstrução como política pública é extremamente complexo e desperta interpretações variadas com implicações de ordem política e ideológica. Vale ressaltar que na prática, a autoconstrução institucionalizada foi adotada por governos sob diferentes modelos de sociedade, incluindo tanto governos capitalistas como socialistas.

Para além das divergências encontradas nos diferentes grupo ideológico, é possível constatar uma multiplicidade de interpretações sobre os principais termos presentes no debate sobre a habitação de ajuda mútua e autoconstrução, contribuindo para ambiguidades que dificultam a análise. "Um dos maiores problemas no debate sobre a habitação por autoconstrução é que é muito difícil definir o que os proponentes entendem por autoconstrução." (BURGESS, 1978, p. 1106).

\section{Política Habitacional de Ajuda Mútua no Brasil}

\begin{abstract}
"Se o mercado de trabalho relega parte da população à pobreza, o mercado imobiliário nega aos pobres a possibilidade de habitar no mesmo espaço em que moram os que podem pagar. Surge uma demanda economicamente inviável mas socialmente inegável." (SINGER, em BONDUKI, 2013, p. 8).
\end{abstract}

No cenário das políticas habitacionais, a prática da autoconstrução foi apoiada e institucionalizada a nível federal em dois períodos: o primeiro, em 1975 - 1986, por meio dos denominados Programas Alternativos implementados pelo Banco Nacional de Habitação (BNH), e o segundo, em 2004 2018, com os programas Crédito Solidário e Minha Casa Minha Vida - Entidades (MCMV-e). Em ambos os períodos, os programas e medidas de apoio à autoconstrução surgiram como alternativas para que a camada mais pobre da população pudesse 
ser contemplada pelas políticas públicas, tendo em vista que os programas tradicionais lançados pelo governo seriam incapazes de atender essa camada de menor poder aquisitivo. Nos dois períodos os programas alternativos tiveram expressão inferior à produção habitacional hegemônica, realizada por meio dos programas tradicionais.

Apesar das diferenças existentes entre cada contexto histórico, os programas tradicionais lançados pelo BNH, na época da ditadura, bem como o programa Minha Casa Minha Vida Empresarial, lançado no governo Lula, guardam similitudes, a saber: os discursos de caráter social presentes na formulação das políticas e dos planos associados aos programas; a predominância da lógica de mercado; a difusão da propriedade individual privada; a falta de participação dos futuros moradores nos processos de decisão; os resultados visíveis no espaço urbano - baseado na produção em massa de conjuntos habitacionais espraiados nas periferias das grandes metrópoles, soluções genéricas, de baixa qualidade construtiva e espacial, carentes de equipamentos urbanos, incapazes de atender adequadamente as diversidades de arranjos familiares. Toda essa extensa produção foi orquestrada, em ambos os períodos, pela confluência entre Estado e empresas privadas do setor imobiliário e da construção civil.

Enquanto os programas tradicionais guardam semelhanças em ambos os períodos, o mesmo não acontece nos programas alternativos de ajuda mútua, que se configuram de formas distintas tanto no processo de formulação quanto na fase de implementação em cada período específico do estudo, como será retratado a seguir.

\subsection{Primeiro Período: 1975 - 1986}

Entre as décadas de 1950/1960, o país passava por mudanças estruturais caracterizadas pelo crescimento econômico, crescimento urbano e pela rápida industrialização. Nesse período, as relações campo-cidade são resignificadas, as migrações se multiplicam e o processo de urbanização se intensifica. Na medida em que se aprofundam as desigualdades sociais, a prática da autoconstrução pelos pobres urbanos configura-se como a principal alternativa para aquisição da casa própria nas grandes cidades brasileiras. "[...] as contradições entre crescimento e pobreza, acumulação e miséria, modernidade e exclusão ficam mais patentes nos modos utilizados pela população trabalhadora e sem salário para promover a moradia". (MARICATO apud LIMA, 2005, p. 124).

Na década de 1970, o momento era de crise econômica e de crise de legitimidade do governo. Após a derrota eleitoral do governo militar, em 1974, o país passava por um processo de transição democrática com uma maior mobilização da população a favor da democracia e com o fortalecimento das entidades da sociedade civil. Concomitantemente, aumentava-se a pressão e as críticas em relação a ineficiência do $\mathrm{BNH}$ quanto ao cumprimento de seus objetivos sociais. Nesse contexto, o BNH a fim de ampliar a faixa de atendimento às populações mais carentes ou de inserção instável no mercado de trabalho, adotou, como estratégia de redução dos custos da habitação, a prática da autoconstrução nas políticas habitacionais, os assim denominados Programas Alternativos. Dessa forma, as famílias de mais baixa renda, as quais em tese, se destinaria o foco da política habitacional, passam a ser relegadas aos programas marginais alternativos.

"[... ao tentar tratar a Autoconstrução e o Mutirão como
uma Politica Habitacional, nas décadas de 70 e 80, pode-
se dizer que a introdução das novas políticas públicas
habitacionais, baseadas na proposta de autoconstrução,
os projetos de mutirão e autogestão foram deixando o
caráter de informalidade e passaram a ser enquadrados
nas políticas municipais." (VIDAL, 2008, p. 151).

Pela primeira vez no Brasil, foi incorporada a prática da autoconstrução nas políticas públicas habitacionais através dos seguintes programas:

- 1975 - PROFILURB - Programa de Financiamento de Lotes Urbanizados: com o objetivo de atender às populações migrantes e de baixa renda - de zero a cinco salários mínimos, o programa previa 
a implantação de conjuntos de lotes urbanizados financiando a legalização da posse da terra e fornecendo infra-estrutura básica, reservando ao mutuário a responsabilidade de construir sua habitação de acordo com suas disponibilidades financeiras e prioridades individuais.

- 1977 - FICAM - Programa de Financiamento de Construção, Conclusão, Ampliação e Melhoria da Habitação: para as famílias com renda de até cinco salários mínimos.

- 1979 - PROMORAR - Programa de Erradicação de Subhabitação e Reurbanização de Favelas: admitia a erradicação do núcleo, ou sua urbanização, tornando-se o primeiro programa a assinalar uma mudança de postura, buscando não mais remover, mas manter os moradores em um núcleo gerado a partir da ocupação de terra.

- 1984 - PROJETO JOÃO DE BARRO - Programa Nacional de Autoconstrução. Autoconstrução por regime de Mutirão: financiava o terreno e cesta de material para construção por mutirão em cidades de pequeno porte.

Esses programas eram destinados às famílias com renda mensal de até 5 salários mínimos, enquadradas assim, no mercado popular². Esse segmento de mercado tinha como agente promotor as Companhias Habitacionais (COHABs), definidas como:

\begin{abstract}
"empresas mistas sob o controle acionário dos governos estaduais e/ou municipais, desempenham, [...] um papel análogo ao dos incorporadores imobiliários na produção de residências para as camadas de renda alta. As Cohab compete coordenar e supervisionar o trabalho das diferentes agências públicas e privadas que participam da edificação das casas populares, reduzindo o preço das unidades produzidas. Essa redução explica-se pela inexistência do "lucro do incorporador", que, em geral, eleva substancialmente o preço final da residências, enquanto que as COHABs, mesmo buscando o equilibrio financeiro, são remuneradas por uma taxa de administração." (AZEVEDO, 1988, p. 111).
\end{abstract}

2 A partir de 1974, as faixas de atendimento das COHABs foram ampliadas de modo a incluir a população cuja renda familiar fosse entre 3 e 5 SM, antes limitado a 1 e 3 SM.
A fim de receber o financiamento do $\mathrm{BNH}$, as COHABs apresentavam projetos tecnicamente compatíveis com a orientação do banco, seguindo a lógica financeiro-empresarial ${ }^{3}$. A gestão e a supervisão das construções acontecia de acordo com as prioridades estabelecidas pelos governos locais. A construção, independente do segmento de mercado, era realizada pela iniciativa privada. Apesar das Cohabs poderem legalmente assumir essa função, as mesmas não se aventuravam nessa empreitada (AZEVEDO, 1982).

Conforme diversos autores referem, com o passar do tempo, esses programas se mostraram muito aquém das expectativas e decepcionaram tanto quantitativamente quanto qualitativamente.

"O fato dos critérios financeiros prevaleceram em relação aos sociais nas definições das diretrizes das politicas habitacionais, inclusive dos programas alternativos, produziu o conceito das moradias progressivas. Um produto inacabado a ser finalizado com mão de obra do futuro morador como o produto "mais adequado" às familias de menor renda, pois só assim, diminuindo os custos e produzindo "escândalos"4, o BNH poderia efetivar esse atendimento." (ROSSETTO, 1993 apud ROYER, 2002).

Foram criticadas as práticas clientelistas quanto aos critérios de alocação dos recursos, bem como, os aspectos relacionados à qualidade das intervenções realizadas pelo PROMORAR e posteriormente pelo programa João-de-Barro. O PROMORAR, representava uma radical alteração na atuação do BNH frente às favelas, abandonando a prática das remoções em prol da manutenção daquela população em seu espaço original. Segundo Leal

3 "O custo reduzido dos projetos arquitetônicos, obtido através de uma relativa padronização das plantas residenciais, e a inexistência de despesas de comercialização (publicidade e corretagem), uma vez que, geralmente, a demanda supera em muito a oferta, são outros fatores que colaboram para a redução dos preços das unidades produzidas pelas Cohab, em comparação a casas similares vendidas no mercado sob o patrocínio de outros agentes." (AZEVEDO, 1988, p. 112).

4 Ermínia Maricato, em entrevista realizada à Revista Proposta $n^{\circ}$ 35. Rio de Janeiro: FASE-RJ, Ano XII, Set/1987, descreve que a produção feita pelo PROMORAR era de habitações de $22 \mathrm{~m}$ “... que foi um escândalo em termos de qualidade" (p.31). 
(1990), a intenção era inegavelmente meritória, e os resultados seriam desastrosos. Quanto à questão jurídica, "a regularização fundiária foi o grande óbice do programa, que teve inúmeras dificuldades para se concretizar." (ROYER, 2002, p. 14).

A respeito do programa PROFILURB, um documento de circulação interna do BNH deixava claro os objetivos do programa: "o Profilurb não se destina à remoção de favelas"5. (FJP, 1980, p. 10). Apesar dessa carta de princípios, "as experiências de lotes urbanizados já implantados indicam que, geralmente, elas surgiram para resolver problemas locais face a necessidade de remoção de favelas ou de desapropriação de áreas para implantação de projetos públicos." [...] "o imediatismo e a pressa em remover populações foram fatores determinantes na escolha de áreas que se revelaram problemáticas." (FUNDAÇÃO JOÃO PINHEIRO, 1980, p. 144). Demais fatores que contribuíram para o fracasso do programa foram a pulverização de áreas e a falta de coordenação entre os agentes (LEAL, 1990).

Nesse momento, a prática do mutirão institucionalizado não incluía a participação dos beneficiários nos processos de decisão, esses forneciam apenas a mão-de-obra para os empreendimentos. "Em alguns casos o desperdício e a má aplicação dos recursos públicos acabaram anulando a economia feita com a utilização da mão-de-obra gratuita." (VIDAL, 2008, p. 72). A descrença e a falta de experiência com a prática de mutirão gerava resistência frente a essa nova modalidade de atuação por parte das Companhias Estaduais e Municipais de Habitação (COHABs).

A idéia da participação da população diretamente envolvida com o projeto era novidade e se constituiu como um forte argumento na formulação dos Programas Alternativos. No entanto, essa participação estava circunscrita ao processo de construção do objeto edificado, traduzindo-se como mão de obra gratuita. (FUNDAÇÃO JOÃO PINHEIRO, 1980). Sobre a participação comunitária nos conjuntos, observa-se que os movimentos comunitários não foram bem desenvolvidos ou organizados:

5 Avaliação do programa PROFILURB realizada pela Fundação João Pinheiro em 1980.
"A participação da COHAB tem se limitado à fase de implantação do projeto, quando seleciona as familias e discute seus problemas, terminando no momento da comercialização, quando os Conjuntos são entregues. [...] 0 paternalismo que até o momento tem permeado a relação desses órgãos com a comunidade é preocupante, pois parece indicar a crença de que a população pobre não é capaz de se autoorganizar de maneira adequada e independente, para enfrentar os desafios que se the antepõem. A impressão que fica é a de que essas instituiçōes ajudariam muito mais se abdicassem de organizar as comunidades e permitissem a estas uma maior autonomia organizativa. Deve-se também mencionar a Taxa de Apoio Comunitário (TAC), que é acrescentada ao encargo mensal dos mutuários para promocão dessa atividade, sem que em muitos lugares a $\mathrm{COHAB}$, realize trabalhos dessa natureza." (FUNDAÇÃO JOÃO PINHEIRO, 1980, p. 166).

Diante desse quadro, a partir da década de 1980, a luta coletiva por moradia realizada por organizações da sociedade civil passa a ganhar um novo caráter e atuação com demandas e propostas alternativas, a fim de influenciar nas políticas habitacionais:

"Ao propor um programa alternativo ao do governo, o movimento por moradia ingressa num campo onde até então não participava: a interferência nas políticas públicas. Fazem crítica à politica habitacional do governo, enfatizando o desinteresse do BNH em atender às parcelas da população de mais baixa renda e aos programas habitacionais, sobretudo o PROMORAR. Criticam-se os intermediários financeiros e as empreiteiras que encarecem o custo de uma moradia que, ademais, é precária. A não consulta à população interessada é um dos aspectos mais enfatizados, considerando-se a politica adotada, além de inadequada é insuficiente para as necessidades mínimas, autoritária e paternalista." (BONDUKI, 1992, p. 41).

Nesse período, são formuladas as propostas básicas dos movimentos de luta por moradia, já incluindo a noção de que os próprios moradores 
organizados deveriam ter o controle do processo de produção das habitações. Nasce daí o embrião da autogestão no Brasil. Os movimentos sociais urbanos organizados nacionalmente têm sua origem neste período e vão se constituir nos principais movimentos de luta por moradia até os dias atuais, a saber: a Confederação Nacional das Associações de Moradores (CONAM) em 1982, a Central dos Movimentos Populares (CMP) em 1993, o Movimento Nacional de Luta pela Moradia (MNLM) em 1990, a União Nacional por Moradia Popular (UNMP) em 1993, e o Movimento dos Trabalhadores Sem Teto (MTST) em 1997.

\subsection{Entre Períodos: 1986 - 2004}

Após 22 anos de existência, o BNH é extinto pelo Decreto-Lei $n^{\circ} 2.291$, de 21 de dezembro de 1986, gerando uma descontinuidade nas políticas nacionais de habitação. Nesse momento, as principais demandas dos movimentos de moradia eram relativas a questão da terra e dos mutirões. "[...] a gente falava que queria que o Estado tivesse terra, a gente queria um financiamento diferente daquele da COHAB, a gente queria o mutirão... Mas não tinha isso muito organizado, formatado". (RODRIGUES E., 2008, apud MOREIRA, 2009, p. 52). Nesse período, a autogestão se colocava ainda de maneira incipiente, sendo assumida muito parcialmente pelos movimentos que não a tinham como palavra de ordem.

Ao longo do processo de redemocratização, o Movimento Nacional pela Reforma Urbana, criado em 1986', estimulou a discussão por meio de novos mecanismos de participação e a politização da questão urbana entre os diversos agentes sociais ligados ao campo habitacional. A atuação dos movimentos sociais foi potencializada e a defesa da autogestão incluída na agenda técnicopolítica desses movimentos ${ }^{7}$. Com o tempo, a

60 Movimento Nacional pela Reforma Urbana reuniu um grupo heterogêneo, contando com uma série de organizações da sociedade civil, movimentos, entidades de profissionais, organizações não-governamentais, sindicatos entre outros.

7 A bandeira da reforma urbana se consolida como: o direito à cidade, que se caracteriza pela gestão democrática e participativa das cidades; pelo cumprimento da função social da cidade; pela garantia da justiça social e de condições dignas a todos os habitantes das cidades; pela subordinação da pro- autogestão habitacional foi se consolidando como uma alternativa concreta para os movimentos de moradia, ampliando seu repertório de projetos e aprofundando suas reivindicações? .

\begin{abstract}
"A atuação dos movimentos sociais urbanos para a garantia do acesso à moradia digna e a demanda por recursos, programas e ações que financiassem a produção autogestionária da habitação manteve os movimentos unificados desde o processo de redemocratização e foi fundamental para a retomada dos investimentos do Estado na politica habitacional e na inclusão de associações e cooperativas como agentes proponentes e executores da política nacional de habitação." (FERREIRA, 2014, p. 25).
\end{abstract}

\subsection{Segundo Período: 2004 - 2018}

Como resultado desse longo processo de negociação, mediação e pressão social - que remonta o início da década de 1980 - o governo federal, em 2004, criou o programa Crédito Solidário voltado para a autogestão com o objetivo de financiar habitações às famílias de baixa renda organizadas em associações, cooperativas, sindicatos e demais entidades da sociedade civil organizada. Entre os anos de 2007 a 2009, foi elaborado o Plano Nacional de Habitação PlanHab - com ampla participação dos membros do Conselho das Cidades e representantes dos diversos segmentos sociais.

Em março de 2009, o Governo Federal lançou o Programa Minha Casa Minha Vida - Empresarial (PMCMV) - elaboradosem a participação do Conselho das Cidades - que se propunha a construção de novas habitações priorizando as famílias de até três salários mínimos, abrangendo também aquelas

priedade à função social; e pelas sanções aos proprietários nos casos de não cumprimento da função social.

8 Em 1988, com a eleição de diversos governos municipais progressistas, de perfil democrático popular, em todo o Brasil, as experiências autogestionárias na produção de habitação de interesse social começaram a se difundir. Exemplo emblemático dessas experiências se deu em São Paulo durante o governo de Luiza Erundina com a criação do FUNAPS - Comunitário (FUNACOM). 
com renda de até dez salários mínimos. Tendo em vista o contexto da crise econômica internacional de 2009, o Programa foi concebido com o objetivo de gerar empregos e investimentos no setor da construção civil e promover o desenvolvimento econômico, reaquecendo o mercado imobiliário no Brasil.

Frente a mobilização dos movimentos de moradia, que não sentiram suas demandas contempladas pelo PMCMV, o Governo Federal criou uma modalidade específica para propiciar a participação das associações e cooperativas habitacionais autogestionárias dentro do PMCMV. Assim surge - Programa Minha Casa Minha Vida - Entidades (PMCMV-e). Apesar do programa ter incorporado algumas das propostas dos movimentos sociais, seu modelo de ação ainda continha características similares ao modelo empresarial, dificultando a execução dos projetos autogestionados pelas entidades. Dessa forma, o programa se mostrou muito aquém das demandas e das expectativas dos movimentos sociais de moradia.

"[... o programa MCMV- Entidades, com seus inúmeros normativos, não foi concebido como um programa que atenda aos princípios da autogestão: ajuda mútua, propriedade e gestão coletivas. Não há liberdade para a experimentação; os grupos são tratados de forma homogênea; a organização do grupo já é previamente definida pelas regras do programa; a propriedade em nome da associação ou cooperativa não é aceita. A gestão coletiva dos recursos por aqueles que serão os futuros moradores é uma das poucas brechas do programa que pode distinguilos dos demais." (FERREIRA, 2014, p. 200).

Infelizmente, não foram criadas as condições favoráveis e esperadas para romper com a falta de tradição de se trabalhar com a prática autogestionária no país. Assim, não podemos afirmar que exista de fato no atual governo um lugar definido na política habitacional para a autogestão. E, por isso o programa que poderia ter o potencial de surpreender os céticos e emocionar os apaixonados, resultou em frustração para aqueles que tinham a perspectiva (ou ilusão) de difundir o princípio da autogestão pelo Brasil (MOREIRA, 2009).

Ao longo dos últimos anos, os movimentos nacionais de luta por moradia foram ganhando corpo e destaque no campo da produção habitacional. As experiências acumuladas, tanto de derrotas como de conquistas, contribuíram para ampliar e fortalecer as organizações de luta, elaborando-se novos planos de ação e estratégias baseados em um modelo de produção-gestão da cidade de forma coletiva e democrática onde a prioridade é o valor-de-uso. Isso se confere na perspectiva do Movimento União Nacional de Moradia Popular (UNMP):

\begin{abstract}
"A UNMP defende a autogestão como uma maneira não só de construir casas, bairros ou equipamentos sociais, mas como uma forma de construção de poder popular. Ao controlar recursos públicos e processos, lutamos contra o clientelismo e a manipulação do poder público sobre a população e as organizações sociais. Construímos alternativas de gestão onde somos sujeitos de nossa história." (UNMP, Ofício ao Ministério das Cidades, abril de 2003).
\end{abstract}

Próximos aos movimentos sociais, novosantigos agentes passaram a participar com mais ênfase nos processos relativos à produção habitacional: entidades acadêmicas, organizações não governamentais sem fins lucrativos, fundações, vem se articulando em redes de cooperação em torno da luta pelo direito à moradia, construindo soluções alternativas de produção habitacional autogestionadas, que conduzem processos coletivos e democráticos de construção de cidade e cidadania, impulsionando, não só a construção de espaços habitáveis mas também a luta à favor do direito à moradia e à cidade.

\section{Considerações finais}

Nos diferentes contextos históricos, a abertura e a qualidade do diálogo entre Estado e sociedade civil oscilou significativamente segundo as negociações e as pressões desses grupos nos processos 
de formulação e implementação das políticas habitacionais. Essas "pressões" e suas ressonâncias se mostraram, em grande parte, em função da relação que essas organizações conseguiram estabelecer para com o poder público, além das condições e da vontade política para reconhecer, apoiar e impulsionar programas, políticas públicas e medidas que suportem essas ações.

No regime militar, era bastante limitada a participação das organizações sociais na execução das políticas habitacionais destinada a população de baixa renda. O papel de executor era desempenhado pelas instituições governamentais, sendo a produção habitacional baseada no binômio Estado - Mercado. Nesse período, a autoconstrução foi incorporada nas políticas públicas habitacionais como resposta à uma crise econômica e de legitimidade do governo militar.

Os projetos habitacionais realizados pelo governo nesse período objetivavam manter o modelo de sociedade conservador e antidemocrático baseado na ideologia da propriedade privada individual, contribuindo para inibir as reivindicações e as manifestações populares. A prática da autoconstrução incluída nos Programas Alternativos do BNH, representava, sobretudo, uma forma de reduzir substancialmente os custos de produção, sendo a "mão de obra gratuita" do trabalhador fundamental para esse objetivo, bem como a racionalidade e agilidade propiciada pelos mutirões institucionalizados - gerenciados pelas COHABs. A ideologia do "sonho da casa própria" e o estímulo à poupança, estavam associados à esses programas como uma forma de disciplinar e acalmar as massas: a casa própria, por mais pequena e sem condições que fosse, contribuia para desmobilizar e evitar que o trabalhador aderisse à manifestações e movimentos revolucionários, além de representar um bem material à família operária, um símbolo de ascensão social, crescimento econômico e valorização do trabalhador, adquirindo este, o status de proprietário dono de terra.

As organizações sociais, reprimidas no período de ditadura, se reconfiguram após a redemocratização, entre elas os movimentos populares de luta por moradia que passam a contribuir, formular, interferir e ser parte da ação pública no campo habitacional, ampliando sua atuação junto ao binômio Estado - Mercado e induzindo as políticas habitacionais na direção das transformações sociais reivindicadas pelas mesmas. Nesse contexto, a autogestão - controle sobre as tomadas de decisão durante o processo - ganha destaque e passa a ser a principal bandeira dos movimentos sociais de luta por moradia. A propriedade coletiva, apesar de pouco implementada, entra no rol de modalidades de títulos de propriedade, representando um caminho contra-hegemônico de distribuição e gestão territorial. A prática do mutirão ganha novo significado, representando não apenas o barateamento do custo da construção da habitação, mas também, um meio para o exercício de processos coletivos e democráticos que permitam a ampliação da organização popular. A contratação de empresas e/ou a remuneração dos trabalhadores no processo de produção das habitações passa a ser "norma".

A produção habitacional se apresenta como um campo de conflito entre diferentes agentes sociais que disputam a produção e a apropriação da cidade, defendendo seus interesses, nem sempre conciliáveis e, muitas vezes, contraditórios. Em cada período do estudo, as noções de mutirão, autogestão e autoconstrução ganharam significados próprios, sendo esses conceitos também objetos de disputa no campo habitacional.

Os agentes responsáveis pela condução dos processos de produção e gestão dos programas habitacionais de ajuda mútua representam grupos e interesses distintos em cada período: no período do $\mathrm{BNH}$, os agentes promotores eram as COHABs - representando os interesses dos governos locais e de certa forma do próprio $\mathrm{BNH}$; no período atual as responsáveis são entidades, cooperativas e associações representando, sobretudo, os interesses da sociedade civil.

Numa direção, os programas alternativos do $\mathrm{BNH}$, orquestrados pelas $\mathrm{COHABs}$, reproduzem o modelo hegemônico governamental de produção habitacional baseado no viés mercadológico e no caráter conservador do regime militar. A empreitada limita-se a construção da casa, não abrangendo a 
organização e emancipação política dos futuros moradores, sendo a participação desses de caráter passivo. Mantém-se assim o modelo de sociedade vigente baseado em processos individualistas, autoritários e não democráticos.

Em outra direção, os processos conduzidos pelos movimentos de luta por moradia e pelas entidades responsáveis pela implementação dos projetos - por meio do programa MCMV Entidades - representam uma ruptura quanto ao modelo de produção habitacional hegemônico: para além da construção das casas, suas ações vão ao encontro da organização e mobilização da população pela reivindicação e luta pelos seus direitos básicos, da investida na formação política dos indivíduos participantes, e da conscientização quanto às questões macroestruturais presentes. Buscam dessa forma construir novos modelos de sociedade baseados em processos coletivos, solidários e democráticos.

A intensa polarização de opiniões que atravessa esse debate reflete uma tendência à generalização e ao maniqueísmo: por um lado a visão da autogestão, autoconstrução e mutirão como espaços de utopia, por outro, vícios da virtude.

Em ambos os períodos do estudo, as políticas públicas embora tenham incluído em algum grau a autoconstrução, a autogestão e o mutirão nos programas habitacionais, os mesmos representaram esforços e processos distintos em cada momento.

Incluir esses processos na discussão do problema habitacional como um todo e principalmente no contexto histórico específico de cada período pode contribuir para diminuir ambiguidades e facilitar o estudo e a análise dessa questão.

\section{Referências bibliográficas}

AZEVEDO, S.; ANDRADE, L. A. G. Habitação e poder. Rio de Janeiro, Ed. Zahar. 1982.

AZEVEDO, S. Política de Habitação Popular: equívocos e mitos sobre a autoconstrução. Revista de Administração Municipal Rio de Janeiro, v. 36, n. 192, p. 28-39, 1989.
AZEVEDO, S. Vinte e dois anos de política de habitação popular (1964-86): criação, trajetória e extinção do BNH. Revista de Administração Pública, v. 22, n. 4, p. 107-119, jul. 1988.

BALTHAZAR, R. D. S. A permanência da autoconstrução: um estudo de sua prática no Município de Vargem Grande Paulista. 2012. Dissertação (Mestrado em Habitat) - Faculdade de Arquitetura e Urbanismo, Universidade de São Paulo, São Paulo, 2012

BERNER, E.; PHILLIPS, B. Left to their own devices? Community self-help between alternative development and neo-liberalism. Community Development Journal, v. 40, n. 1, p. 17-29, 2005.

BONDUKI, N. G. Habitação e Autoconstrução: Construindo Territórios de Utopia. Rio de Janeiro: FASE, 1992.

BONDUKI, N. G. Origens da habitação social no Brasil: o caso de São Paulo. 1994. Tese (Doutorado) - Faculdade de Arquitetura e Urbanismo, Universidade de São Paulo. São Paulo. 1994.

BONDUKI, N. G. Origens da habitação social no Brasil: arquitetura moderna, lei do inquilinato e difusão da casa própria. São Paulo: Estação Liberdade, 2013.

BURGESS, R. Self-Help Housing: A New Imperialist Strategy? A Critique of the Turner School. Antipode, v. 9 (2), p. 50-59, 1977.

BURGESS, R. Petty Commodity Housing or Dweller Control? A Critique of John Turner's Views on Housing Policy. World Development, v. 6, n. 9-10, p. 1105-1133, 1978.

BURGESS, R. Helping some to help themselves: third world housing policies and development strategies. In: MATHEY, K., Beyond self-help housing. London: Mansell Publishing, p. 75-94, 1992.

FERREIRA, R. F. C. F. Autogestão e habitação: entre a utopia e o mercado. 2014. Tese (Doutorado 
em Planejamento Urbano e Regional) - Instituto de Pesquisa e Planejamento Urbano e Regional, Universidade Federal do Rio de Janeiro. Rio de Janeiro. 2014.

FUNDAÇÃO JOÃO PINHEIRO, Diretoria de Planejamento Social e Urbano. Avaliação do PROFILURB no Brasil. Belo Horizonte: Fundação João Pinheiro, 1980.

GOHN, M. G. M. Movimentos sociais e lutas pela moradia. $1^{a}$ ed. São Paulo: Ed. Loyola, 1991.

HARRIS, R. The silence of the experts: "Aided selfhelp housing", 1939-1954. Habitat International, v. 22, n. 2, p. 165-189, 1998.

HARRIS, R. Slipping through the Cracks: The Origins of Aided Self-help Housing, 1918-53. Housing Studies, v. 14, n. 3, p. 281-309, 1999.

\section{LEAL, E. P. B. Evolução Urbana e a questão} da Habitação no Brasil: 1964-1988. 1990. 2v. Dissertação (Mestrado) - Universidade Estadual Paulista, Faculdade de Ciências e Letras de Assis. Assis, 1990.

LIMA, R. M. C. A cidade autoconstruída. 2005. Tese (Doutorado em em Planejamento Urbano e Regional) - Instituto de Pesquisa e Planejamento Urbano e Regional, Universidade Federal do Rio de Janeiro. Rio de Janeiro. 2005.

MARICATO, E. A produção capitalista da casa (e da cidade) no Brasil industrial. $2^{a}$ ed. São Paulo: Ed. Alfa-ômega, 1979.

MOREIRA, F. A. O lugar da autogestão no Governo Lula. 2009. Dissertação (Mestrado em Habitat) - Faculdade de Arquitetura e Urbanismo, Universidade de São Paulo, São Paulo, 2009.

NTELMA, L. J. Self-help Housing in South Africa: Paradigms, Policy and Practice. 2011. PhD Thesis - University of South Africa. 2011. acumulação capitalista no Brasil. Novos estudos CEBRAP, v. 74, p. 67-85, 2006.

RODRIGUES, E. L. A estratégia fundiária dos movimentos populares na produção autogestionária da moradia. 2013. Dissertação (Mestrado em Habitat) - Faculdade de Arquitetura e Urbanismo, Universidade de São Paulo, São Paulo, 2013.

ROSSETO, R. Organismos Internacionais e a auto-construção: análise e reflexões sobre as políticas de habitação para a população de baixa renda. 1994. Dissertação (Mestrado em Habitat) - Faculdade de Arquitetura e Urbanismo, Universidade de São Paulo, São Paulo, 1994.

ROYER, L. Política habitacional no estado de São Paulo: estudo sobre a Companhia de Desenvolvimento Habitacional e Urbano do estado de São Paulo. 2002. Dissertação (Mestrado em Habitat) - Faculdade de Arquitetura e Urbanismo, Universidade de São Paulo, São Paulo, 2002.

TURNER, J. F. C. Housing as a Verb. In: Turner, J.F.C; FICHTER, R. (Eds). Freedom to Build, dweller control of the housing process. New York: Collier Macmillan, p. 149-175, 1972.

TURNER, J. F. C. Housing by People: Towards Autonomy in Building Environments. 2nd ed. London: Marion Boyars Publishers Ltd, 2000.

VIDAL, F. E. C. A autoconstrução e o mutirão assistidos como alternativas para a produção de habitações de interesse social. 2008. Dissertação (Mestrado em Arquitetura e Urbanismo) Universidade de Brasília, Brasília, 2008.

WORLD BANK. World Development Report 1997: The state in a changing world. Oxford: Oxford University Press, 1997. 
Publicação organizada pelo Programa de

Mestrado Profissional Stricto Sensu em

Engenharia Civil da Universidade São Judas

Volume 03 - Edição 01

Janeiro - Dezembro de 2020

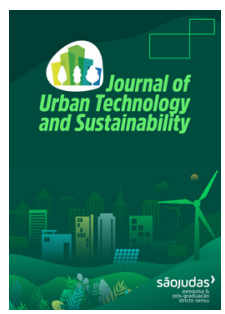

\section{A seca e seus desdobramentos: reflexões a partir da realidade da Microrregião de Pau dos Ferros}

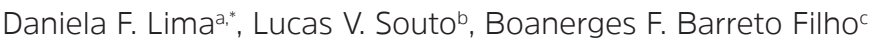

${ }^{a}$ Programa de pós-graduação em Engenharia Civil e Ambiental, Universidade Federal de Campina Grande, Campina Grande, Brasil.

${ }^{b}$ Programa de pós-graduação em Planejamento e Dinâmicas Territoriais do Semiárido, Universidade do Estado do Rio Grande do Norte, Mossoró, Brasil.

cDepartamento de Economia, Campus Avançado de Pau dos Ferros, Universidade do Estado do Rio Grande do Norte, Pau dos Ferros, Brasil.

\section{Informações}

Recebido 19 Setembro 2020

Manuscrito revisado recebido

19 Novembro 2020

Aceito 27 Novembro 2020

Palavras-chave

Dificuldade hídrica

Combate à seca

Convivência com a seca

Medidas emergenciais

\section{Resumo}

A região Nordeste sempre foi vista como a região da seca, do subdesenvolvimento, do homem desamparado e de diversos estereótipos que consagraram a caracterização de sua configuração humana, econômica e espacial. A ausência de água é um aspecto marcante, que além de flagelar o nordestino, é utilizada como aporte político por representantes governamentais em discursos de "solução à seca" para adquirirem apoio popular. O objetivo deste trabalho é apresentar a perda de importância das atividades rurais na microrregião de Pau dos Ferros/RN e discutir as medidas emergenciais adotadas para amenizar a escassez de água neste município. Foi realizado levantamento de dados com foco nas variáveis População e Produto Interno Bruto Agropecuário; coletados dados na Secretaria de Desenvolvimento Rural de Pau dos Ferros/RN; e realizadas buscas acerca da questão hídrica deste município em portais online. Diante disso, foi observada a relativa perda de participação do PIB agropecuário na composição do PIB Municipal, redução da população rural nessa microrregião e a implantação de ações paliativas de combate à seca.

\section{Drought and its consequences: reflections from the reality of the Pau dos Ferros Microregion}

\author{
Article info \\ Received 19 September \\ 2020 \\ Received in revised form 19 \\ November 2020 \\ Accepted 27 November \\ 2020 \\ Keywords \\ Water scarcity \\ Combat to drought \\ Living with drought \\ Emergency measures
}

\begin{abstract}
The Northeast region has always been the region of drought, underdevelopment, the destituous man and several other stereotypes that enshrined the characterization of their human, economic and spatial configuration. The absence of water is a striking aspect, which in addition to flagellating the Northeastern region, is used by government representatives to adopt "solution to drought" speeches to acquire popular support. The objective of this work is to present the loss of importance of rural activities in the microregion of Pau dos Ferros/RN and to discuss the emergency measures adopted to alleviate water scarcity with emphasis in this municipality. Data were collected focusing on the variables Population and Gross Agricultural Domestic Product; data were collected at the Secretariat of Rural Development of Pau dos Ferros/RN city; and searches were carried out about the water issue of this municipality in online portals. Therefore, what was observed was the relative loss of participation of agricultural GDP in the composition of municipal GDP, reduction of the rural population in this microregion and the implementation of palliative actions to combat drought.
\end{abstract}

\section{La sequía y sus consecuencias: reflexiones desde la realidad de la Microrregión de Pau dos Ferros}

\section{Información}

Recibido 19 Septiembre 2020

Manuscrito revisado recibido 19 Noviembre 2020

Aceptado 27 Noviembre 2020

\section{Palabras clave}

Falta de agua

Combate a la sequía

Convivir con la sequía

Medidas emergenciales

\section{Resumen}

La región Nordeste siempre ha sido vista como la región de la sequía, el subdesarrollo, el hombre indefenso y diversos estereotipos que consagraron la caracterización de su configuración humana, económica y espacial. La ausencia de agua es un aspecto llamativo que, además de azotar al Nordeste, es utilizado como aporte político por los representantes del gobierno en discursos de "solución a la sequía" para ganar apoyo popular. El objetivo de este trabajo es presentar la pérdida de importancia de las actividades rurales en la micro región de Pau dos Ferros / RN y discutir las medidas de emergencia adoptadas para paliar la escasez de agua en este municipio. Se realizó una encuesta de datos con foco en las variables Población y Producto Interno Bruto Agropecuario; los datos se recopilaron en la Secretaría de Desarrollo Rural de Pau dos Ferros / RN; y se realizaron búsquedas sobre el tema del agua de este municipio en portales en línea. Ante esto, se observó la pérdida relativa de participación del PIB agrícola en la composición del PIB Municipal, la reducción de la población rural en esta microrregión y la implementación de acciones paliativas para combatir la sequía.

\footnotetext{
* Autor correspondente em: Departamento de Engenharia Civil e Ambiental, Universidade Federal de Campina Grande, Campina Grande, Brasil. 


\section{Introdução}

A seca é uma das características mais ressaltadas quando se faz referência ao Nordeste, seguida pelo discurso que a descreve como a região da pobreza, da miséria, do subdesenvolvimento e dos flagelados. Assim, a partir de uma característica climática, constrói-se uma narrativa, ou melhor, uma imagem sobre uma imensa área geográfica marcada por estereótipos e por preconceito.

Essa trama foi sendo construída e consolidada através dos grandes jornais do Sudeste, de São Paulo e do Rio de Janeiro principalmente, a partir da cobertura de fatos históricos, como a Guerra de Canudos, o Cangaço, as sucessivas secas, contribuiu também a literatura regionalista ${ }^{1}$ e ainda, talvez o componente mais emblemático, o discurso da elite política nordestina. O poder dessa construção imagética se cristaliza pelo apoio das massas e se propaga, por várias décadas, fazendo com que parte dos nordestinos se considere na condição de subalternidade e castigado pela inclemência da natureza.

Saliente-se que as intervenções pontuais realizadas pelas autoridades públicas, através da construção de alguns reservatórios e dos socorros públicos nos períodos de secas mais severas, só ganham contornos de políticas públicas a partir da criação de órgãos especializados para o enfrentamento do problema, dentre eles: Comissão Imperial; Inspetoria Federal de Obras Contra às Secas (IFOCS), Departamento Nacional de Obras Contra às Secas (DNOCS), Superintendência de Desenvolvimento do Nordeste (SUDENE) ${ }^{2}$.

\footnotetext{
1 De acordo com Albuquerque Júnior (2017, p. 225): "essa literatura construiu um conjunto de imagens e enunciados que, ainda hoje, permanecem como o 'ser' mesmo da seca do Nordeste do Brasil. Ignoradas pela vasta produção historiográfica existente a respeito desse fenômeno, essas imagens e cenas vão ser figuradas, inicialmente, e recorrentemente reapresentadas na produção literária que se diz regionalista, sendo posteriormente apropriadas por outros gêneros narrativos e artísticos. Mesmo em permanente reelaboração e reinscrição, essas imagens retirantes, sobrevivem e retornam periodicamente nos discursos em torno desse fenômeno dito regional".
}

2 A SUDENE não é um órgão público especializado no combate à seca, mas se insere na lógica do paradigma da modernidade e do discurso da elite política regional. Embora seja necessário ressaltar a diferenciação entre o propósito originário para sua criação, demonstrado no trabalho chefiado por Celso Furtado e que resultou no Relatório do Grupo de Trabalho para o Desenvolvimento do Nordeste (GTDN), em comparação com as
Neste aspecto, a preponderância deste enredo discursivo se encontra com o paradigma da modernidade, uma vez que a realização de grandes obras de infraestrutura hídrica é a forma de manifestação concreta, ensejando, portanto, a perspectiva tecnicista da primazia humana sobre a natureza e de sua utilização para fins de exploração econômica (SILVA, 2003). Podese afirmar que o paradigma do combate à seca foi o balizador das intervenções realizadas pelo Estado brasileiro ao longo do tempo no Semiárido, direcionando-se volumes expressivos de recursos para obras de construção de grandes reservatórios hídricos e ações subsidiárias, como a implantação de perímetros irrigados, a construção de sistemas adutores e, mais recentemente, inaugurandose uma nova forma de intervenção, a partir da transposição de águas do rio São Francisco.

Contudo, mesmo considerando a relevância das intervenções, evidencia-se que as realidades socioeconômica e ambiental predominantes no Semiárido ainda são marcadas por elevados índices de pobreza, baixíssimo dinamismo econômico e acentuado processo de degradação da natureza. Sendo plausível supor que a situação não é ainda mais dramática em função do intenso processo de migração, do rural para o urbano, em que milhares de pessoas acorreram para as cidades em busca de melhorias nas condições de vida, acrescido de ações implementadas pelo Estado, preponderantemente orientadas pelo paradigma do combate à seca e por um número menor de experiências relacionadas à convivência.

Ao longo do tempo a migração campo-cidade ocorreu de forma acentuada na Microrregião de Pau dos Ferros, fortemente influenciada pelas consequências da seca, fenômeno natural recorrente que, historicamente, não recebeu a devida atenção por parte das autoridades públicas. O que ocorreu desde a transição dos séculos XIX para o XX até os dias atuais foram os gastos excessivos com o combate à seca (SILVA, 2007),

ações realizadas, especialmente após o golpe militar de 1964, notadamente, subordinadas à estratégia de industrialização, espacialmente concentrada no Centro Sul e cabendo ao setor industrial nordestino o papel de complementação, bem como a estratégia de desenvolvimento rural fundamentada na modernização conservadora da agricultura. 
por meio de vultuosos investimentos na construção de barragens, adutoras, distribuição de água e políticas de transferência de renda. Reconhecese que essas medidas de combate são, em curto prazo, importantes para a população, mas não possibilitam uma convivência que promova a fixação do homem na zona rural e nem foram capazes de proporcionar desenvolvimento humano, ou seja, aumento do bem-estar.

$\mathrm{Na}$ Microrregião de Pau dos Ferros ocorreu um intenso processo de migração, do rural para o urbano, onde as pessoas deslocavam-se em busca de melhoria de vida. Dantas e França (2016) apontam que, "ocorreram mudanças econômicas, sociais, demográficas e espaciais em todo o país, mas essas mudanças não foram capazes de modificar, em termos estruturais, as disparidades regionais existentes". Consequentemente graves problemas sociais relacionados à moradia, saúde, educação, emprego e renda se tornaram mais evidenciados nas áreas mais pobres do país, como é o caso da área objeto deste estudo.

O município que dá nome a Microrregião, Pau dos Ferros/RN, exerce uma grande influência sobre os demais municípios circunvizinhos por seu potencial na oferta de serviços e empregos, podendo ser caracterizada como cidade (inter)média devido ao atributo de intermediação e polarização entre diversas cidades, como apontaram Dantas, Clementino e França (2014).

Os mecanismos de expulsão/atração são complexos, mas é defensável que a extrema pobreza rural existente no Nordeste seja um incentivo para a migração. Acrescentem-se a ausência/ insuficiência de medidas mitigadoras do problema e os incentivos, velados e explícitos, por parte do Estado brasileiro para acelerar a urbanização que se compreende a transumância nos períodos de secas mais duradoras.

Acredita-se que a extrema pobreza e pobreza do meio rural do Semiárido, em geral, e da Microrregião de Pau dos Ferros, em particular, em associação com o fenômeno da seca e de ausência/insuficiência de medidas mitigadoras foram determinantes para a migração campo-cidade que ocorreu de forma acentuada na Microrregião de Pau dos Ferros.
Neste sentido, o trabalho objetiva apresentar a perda de importância das atividades rurais na Microrregião de Pau dos Ferros e debater acerca das medidas emergenciais utilizadas para reduzir a dificuldade de acesso à água no semiárido nordestino, decorrente da irregularidade dos períodos chuvosos, com ênfase no município de Pau dos Ferros/RN por ser bastante representativo da realidade microrregional.

Alguns elementos, como a demografia, especialmente a evolução da população rural; a economia, com ênfase na participação do Setor Agropecuário na composição do Produto Interno Bruto (PIB) municipal; e as ações do Estado relacionadas à seca, oferecem subsídios para respaldar a discussão.

\section{Metodologia}

\section{1. Área de estudo}

Segundo a classificação das cidades dada pelo IBGE, todas as cidades que compõem esse estudo enquadram-se como cidades de pequeno porte, pois possuem população abaixo de 100 mil habitantes. Mas, Pau dos Ferros/RN contraria essa lógica, caracterizando-se como uma cidade (inter) média, devido a sua forte capacidade polarizadora e de influência na região, onde são ofertados serviços variados (educação, saúde, jurídicos, bancários e etc.), sendo um centro comercial regional onde se tem grande volume de negócios, que impactam no emprego e na renda (DANTAS, 2014).

A respeito do processo de constituição de Pau dos Ferros/RN e dos municípios que o circundam, Dantas, Clementino e França (2014), relatam que, o processo de formação teve origem no capital mercantil através do binômio gado-algodão que movimentou a economia do sertão nordestino por muito tempo.

Essa microrregião é localizada na área do semiárido brasileiro, mais especificamente no Alto Oeste do estado do Rio Grande do Norte. O bioma preponderante é a Caatinga, vegetação essa específica das áreas de clima seco que conseguem 


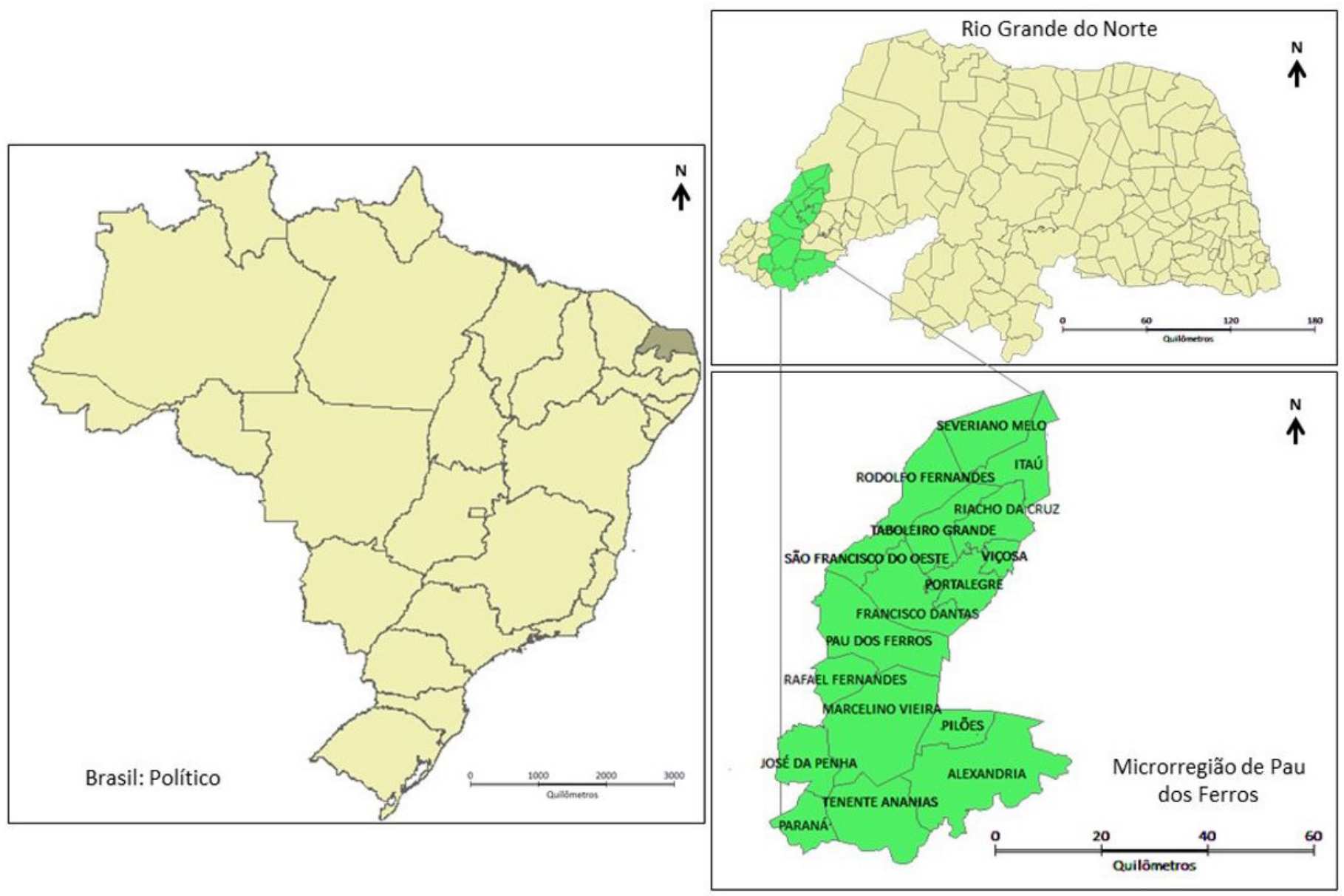

Fig. 1. Municípios que compõem a Microrregião de Pau dos Ferros (SOUTO; SOUSA JUNIOR; LIMA JÚNIOR, 2019).

suportar grandes períodos de estiagem. A média pluviométrica varia de 200 a 800 mm ano (AB'SABER, 2003).

A Figura 1 mostra a localização geográfica e externa os dezessete municípios que compõem a microrregião, onde a maioria destes possuem baixa densidade populacional. Em 2010, os 17 municípios tinham uma população de 114.267 habitantes, alcançando, em 2019, uma população estimada de 117.812 habitantes (IBGE, 2010; 2020).

Em 2010, 15 municípios tinham menos de 10 mil habitantes, destacando-se Pau dos Ferros/ RN com 27.745 habitantes (maior população) e o município de Viçosa/RN com 1.618 habitantes (menor população) (IBGE, 2010). Em 2020, Pau dos Ferros/RN, com 30.600 habitantes, continua como o município de maior população e Viçosa/ RN, com 1.725 habitantes, o de menor população (IBGE, 2020).

De acordo com o Atlas do Desenvolvimento Humano no Brasil (2010), o Índice de Desenvolvimento Humano Municipal (IDHM) médio da microrregião é de 0,6099, isso caracteriza os municípios de acordo com a metodologia do índice na categoria de médio desenvolvimento. A variável que mais contribuiu para a melhoria do desenvolvimento humano nesses municípios foi a variável "Longevidade". Quando se fala de concentração de renda, o Índice de Gini médio auferido é de aproximadamente 0,4847.

\subsection{Procedimentos metodológicos}

Para consecução do presente trabalho foram adotadas as fases:

- Realização de um estudo de levantamento dos dados disponibilizados nas bases do Instituto Brasileiro de Geografia e Estatística (IBGE). As variáveis selecionadas para análise dos municípios que compõem a microrregião de Pau dos Ferros/ RN foram População e Produto Interno Bruto Agropecuário;

- Execução de coleta de documental no ano de 2016, composta por relatórios da perfuração de 
poços em Pau dos Ferros/RN na Secretaria de Desenvolvimento Rural do município de Pau dos Ferros/RN;

- Visitas in loco no ano de 2016 para verificação da situação hídrica e medidas adotadas para atenuar os impactos negativos da escassez em Pau dos Ferros/RN;

- Investigação do panorama hídrico de Pau dos Ferros/RN em portais online dos órgãos associados à gestão de água do Rio Grande do Norte e da Agência Nacional de Águas (ANA).

\section{O fator climático e suas implicações na dinâmica regional}

De acordo com a Resolução $n^{0} 115$, de 23/11/2017, do Ministério da Integração Nacional e Superintendência do Desenvolvimento do Nordeste (SUDENE), o Semiárido brasileiro é composto por 1.262 municípios, dos estados do Maranhão, Piauí, Ceará, Rio Grande do Norte, Paraíba, Pernambuco, Alagoas, Sergipe, Bahia e Minas Gerais. A Figura 2 apresenta o recorte geográfico indicado nesta Resolução (SUDENE, 2017).

Dados da SUDENE (2017) expõem que 22,5\% dos municípios do Brasil são integrantes do Semiárido, dos quais o Nordeste abriga a liderança deste quantitativo, 1171 dos 1262 municípios, e o Rio Grande do Norte detém 147 (dos 167 inseridos em seu território).

Apesar do semiárido nordestino ser uma das regiões que possuem o clima semiárido com maior capacidade de armazenamento de água do mundo, seus reservatórios são a céu aberto, além de não haver manutenção periódica para desassoreamento e recuperação de matas ciliares, o que facilita a evapotranspiração que, de acordo com Malvezzi (2007) é três vezes maior do que os índices de precipitação. Além da evapotranspiração, que ocorre com maior intensidade quanto mais raso for o reservatório, $70 \%$ do solo do semiárido é cristalino, o que dificulta a infiltração, fazendo com que água das chuvas escoe para os rios intermitentes e, posteriormente deságue no mar ou evapore antes deste fenômeno.

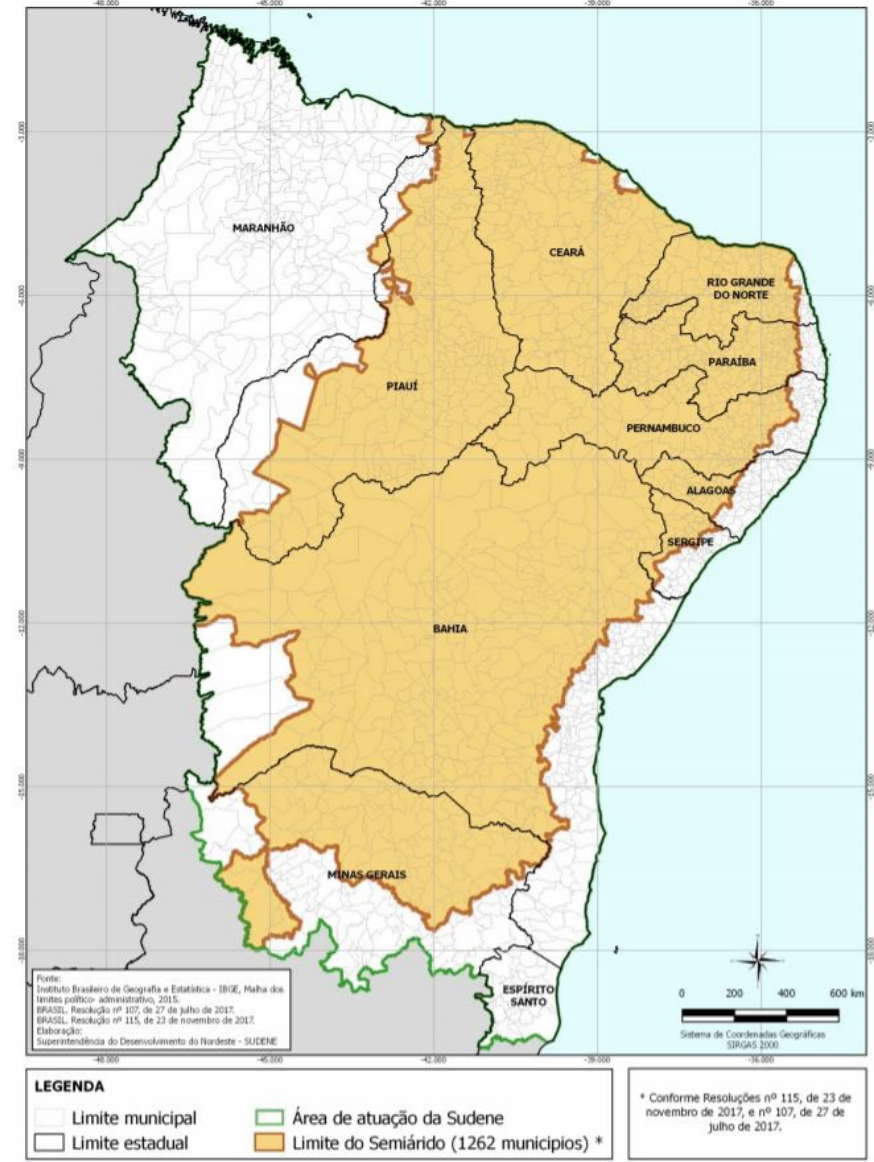

Fig. 2. Espaço geográfico no semiárido (SUDENE, 2017).

O semiárido nordestino é o mais chuvoso do planeta, com pluviosidade média de 750 mm/ ano. Assim, a convivência com o semiárido não corresponde a extinguir a seca, mas adaptar-se ao ambiente de forma inteligente, que corresponde principalmente ao armazenamento de água com o impedimento da evaporação. A exemplo de técnicas de captação e armazenamento estão as cisternas de placas, que são hermeticamente fechadas e captam água das chuvas por meio de calhas (MALVEZZI, 2007).

Foi a partir dos anos 1980 que a sociedade civil e entidades públicas de pesquisa passaram a implantar mecanismos de convivência com o semiárido, rompendo com o antigo paradigma do combate que beneficiou a indústria da seca durante todo o século XX (SILVA, 2007).

Uma dessas entidades que disseminam técnicas de convivência com o semiárido é a Articulação no Semiárido Brasileiro (ASA), formada pela união de diversas organizações da sociedade civil, constituída no início da década de 1990, que possui em seu escopo vários programas que viabilizam a 
permanência e a subsistência da população que vive na região semiárida brasileira. Entre seus programas estão: Programa Um Milhão de Cisternas (P1MC), Programa Uma Terra e Duas Águas (P1+2), Programa Cisternas nas Escolas, Programa de Manejo da Agrobiodiversidade (Sementes do Semiárido).

O P1MC que é o carro chefe e tem como objetivo construir cisternas de placa nas casas das zonas rurais para que seja armazenada a água da chuva no inverno para quando o período de estiagem chegar essa população possa ter pelo menos água para o consumo humano. Até novembro de 2016, ano foco deste trabalho, foram construídas 588.935 cisternas em toda região semiárida, o que representa 59\% do objetivo final (ASA, 2016). Esse número evoluiu para 628.355 até setembro de 2020 (ASA, 2020). A ASA recebe recursos do governo federal e de entidades privadas para que possa continuar o trabalho junto a população alvo.

Como já é sabido e amplamente divulgado, a região semiárida nordestina apresenta grandes períodos de estiagem desde o início de seus registros, que datam da época do Brasil colônia. Neste aspecto, a Microrregião de Pau dos Ferros foi e continua sendo muito afetada pela ocorrência de secas. A mais recente ocorreu no período de 2012 a 2017, resultando em diversos problemas ambientais, sociais e econômicos. Ressalta-se que os anos de 2011, 2018 e 2019 também não tiveram pluviometria favorável em Pau dos Ferros/RN e o reservatório principal desta cidade não obteve recarga satisfatória para atendimento de suas demandas.

Muito embora a Microrregião de Pau dos Ferros tenha o Setor de Serviços como principal fator dinamizador da economia, observa-se que ainda existe uma presença marcante da agricultura familiar, nem tanto no sentido estritamente econômico, mas como elemento representativo da história, da cultura e da conformação social microrregional.

Salienta-se que o Setor Agropecuário microrregional é caracterizado pela ausência de mecanização ou técnicas sofisticadas que auxiliam na produção, impactando na baixa produtividade e baixa escala das culturas. Para que se tenha aumento de produtividade são necessárias políticas públicas e aporte de recursos públicos e privados.

Todavia, o capital tende a se mover para os territórios e setores onde pode auferir maior retorno, consequentemente, caso não ocorra a intervenção do poder público nas áreas predominantemente semiáridas, o capital privado não será direcionado para tais áreas, mantendo-as em desvantagens, subdesenvolvida e obsoleta frente às áreas de expansão do agronegócio das regiões Sul, CentroOeste e Sudeste do país.

Ou seja, é de extrema importância a efetivação de políticas públicas que fomentem o desenvolvimento da região semiárida, que colabore para que a população que vive nesse espaço possa permanecer nele e dele retirar renda suficiente para prover níveis satisfatórios de bem-estar.

Existem diversos exemplos internos e externos de que a convivência com as regiões áridas e semiáridas é totalmente possível e viável. A nível externo ao país, tem-se o caso de Israel, país localizados no oriente médio, mais especificamente no continente asiático, onde este possui vasta região de clima árido, baixa incidência pluviométrica, escassez de água e boa parte dos solos desérticos, mas que sempre buscou mecanismos para conviver com as intempéries do clima, tanto que se apresentam como os pioneiros nas técnicas de irrigação por gotejamento, dessalinização da água e reaproveitamento da água do esgoto para irrigação, sendo hoje autossuficientes em diversas culturas (BLECHER, 2012).

Do ponto de vista interno, há ilhas de prosperidade que estão na região semiárida, como são os casos da região de Juazeiro/Petrolina (Bahia/Pernambuco), as margens do rio São Francisco, de Açu/Mossoró (RN) e Morada Nova/Limoeiro do Norte (CE), áreas estas que estão sob a égide da indústria agrícola tipo exportação, mas que apresentam alta produtividade e grande escala, pois têm acesso aos principais insumos: água, terra e capital humano.

A Figura 3 mostra os níveis da seca no Nordeste brasileiro, segundo a metodologia do Monitor de Secas, no mês de setembro do ano de 2016, ano 


\section{Setembro/2016}

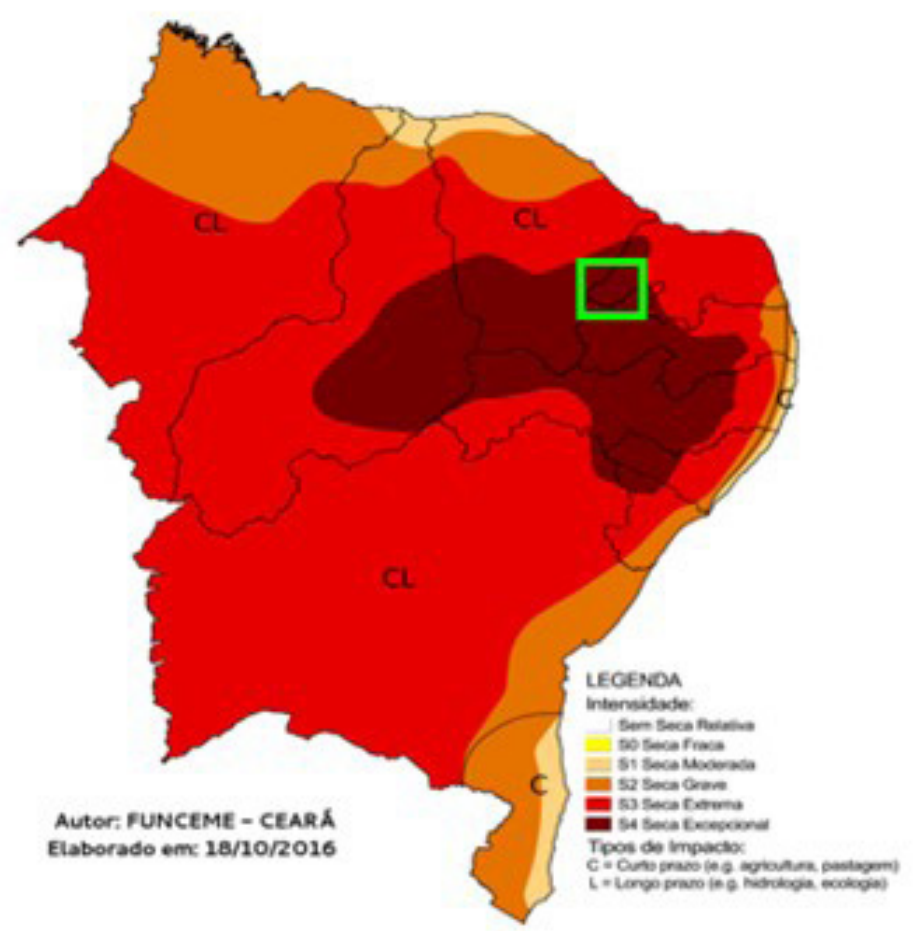

Julho/2020

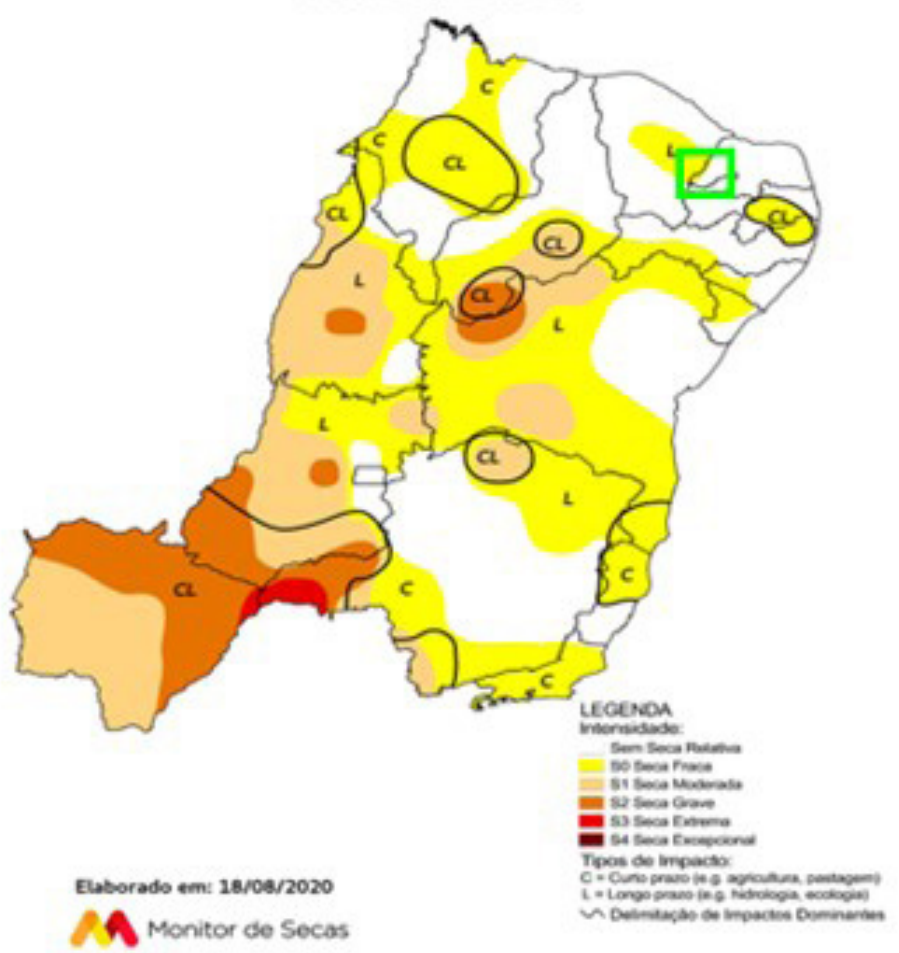

Fig. 3. Monitor de Secas (adaptado de ANA, 2020b).

base desta pesquisa, e no mês de julho de 2020, época em que a situação de escassez hídrica foi atenuada na microrregião objeto de estudo deste trabalho.

De acordo com a ANA (2020), o Monitor de Secas é um instrumento de análise regular e periódica da situação da seca no Nordeste, cujos resultados consolidados são divulgados por meio do Mapa do Monitor de Secas. Mensalmente informações sobre a situação de secas são disponibilizadas até o mês anterior, com indicadores que refletem o curto prazo (últimos 3, 4 e 6 meses) e o longo prazo (últimos 12, 18 e 24 meses), indicando a evolução da seca na região.

O monitor é composto por cinco categorias, com o intervalo que compreende SO a S4, onde SO é o nível mais fraco de seca e S4 é o nível mais forte, chamado seca excepcional. Na Figura 3, que exibe o referido monitor, a região analisada no presente trabalho está sinalizada dentro do quadrado verde, na parte oeste do estado do Rio Grande do Norte. Esta região era caracterizada no ano de 2016 pela categoria S4 (seca excepcional), onde os impactos da seca estavam em seu grau máximo, ocasionando: perdas de cultura; escassez de água nos reservatórios, córregos e poços de água; criando situações de emergência e calamidade pública, fato que motivou este estudo nesta época.

\section{Indicadores demográfico e econômico}

A partir da Figura 4 verifica-se que todos os municípios da Microrregião de Pau dos Ferros apresentaram redução da participação do PIB agropecuário sobre o PIB total municipal, tendo como ponto de referência o início da série e o final. Entre o ano de 2008 e 2012 a tendência de queda é observada de forma acentuada em todos os municípios em questão, após esse período o percentual de participação oscila em baixa.

Os dados apontam a perda de participação do Setor Agropecuário na economia dos municípios da Microrregião de Pau dos Ferros, demonstrando que as economias municipais se tornaram cada vez mais dependentes dos segmentos atrelados ao urbano, especialmente o Setor de Serviços. Os anos de 2016 e 2017 apresentaram os menores valores de representatividade para cerca de 65\% dos municípios da Microrregião de Pau dos Ferros, época de elevada escassez hídrica. 


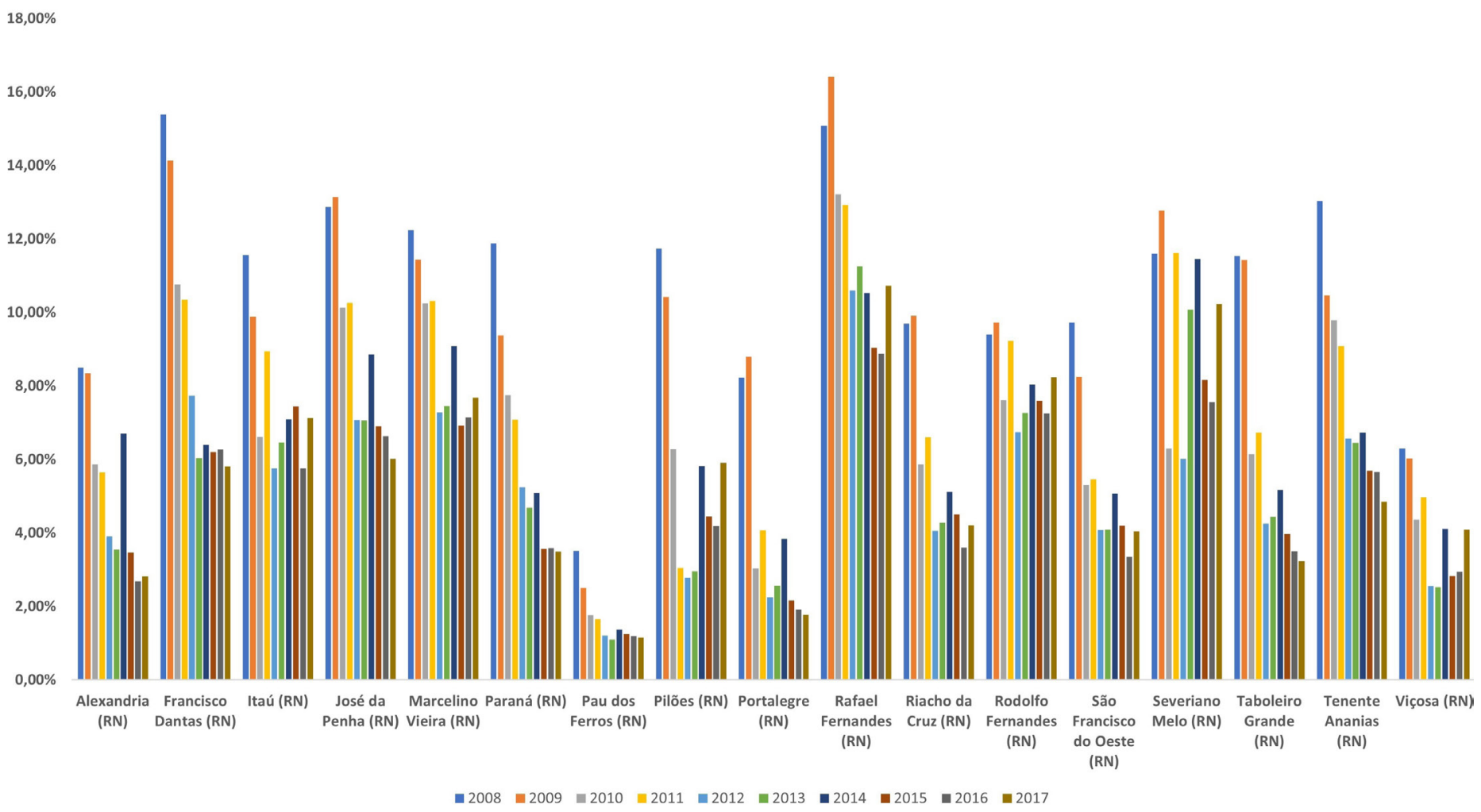

Fig. 4. Participação do PIB Agropecuário no PIB Total Municipal (\%) de 2008-2017 (adaptado de IBGE, 2019).

Apesar de algumas oscilações nos anos de 2003 a 2008, início da série do Instituto Brasileiro de Geografia e Estatística que contabiliza os produtos municipais, observa-se que o comportamento do PIB Agropecuário é de redução com o passar do tempo, sugerindo que a perda de importância do Setor Agropecuário já era uma tendência no espaço microrregional. Destaca-se que as políticas públicas implementadas no início do século XX não se destinaram a potenciar a pequena produção agropecuária. Ademais, pode-se presumir que - Programa Nacional de Fortalecimento da Agricultura Familiar (PRONAF, 1996), estabelecido Decreto n ${ }^{0}$ 1.946/1996, e o Programa de Aquisição de Alimento (PAA, 2003), instituído pela Lei $n^{\circ}$ 10.696/2003, não impactaram significativamente a agropecuária microrregional, mesmo num período de chuvas mais regulares, embora contribuindo, muito provavelmente, para aliviar a pobreza rural.

Observa-se, por meio da Figura 5, que ocorreu a diminuição da população rural na Microrregião de Pau dos Ferros/RN, no período que compreende os três últimos Censos Demográficos.

A tendência de redução da população rural é um fenômeno nacional que vem sendo a tônica do pós-Segunda Guerra Mundial, mas com diferentes velocidades nos distintos recortes geográficos, em geral, obedecendo ao sentido de deslocamento populacional de áreas pobres para aquelas com maior dinamismo econômico. Verifica-se que, no período de 1991 para 2010, a população rural diminuiu oito pontos percentuais no Brasil, nove pontos percentuais no Rio Grande do Norte e dezesseis pontos percentuais na Microrregião de Pau dos Ferros, restando evidente que o estado potiguar vem acompanhando o ritmo nacional e a Microrregião apresenta um ritmo mais intenso de queda da população rural.

\section{Panorama hídrico de Pau dos Ferros}

No ano de 2016, o principal reservatório do município de Pau dos Ferros/RN, denominado Barragem de Pau dos Ferros, estava com sua capacidade de abastecimento totalmente esgotada em decorrência das escassas precipitações na região que o abasteciam, consequência da forte seca apresentada desde anos anteriores, como mostra a Figura 6.

De acordo com o Instituto de Gestão de Águas do Rio Grande do Norte (IGARN, 2017), o volume que pode ser armazenado na Barragem de Pau 


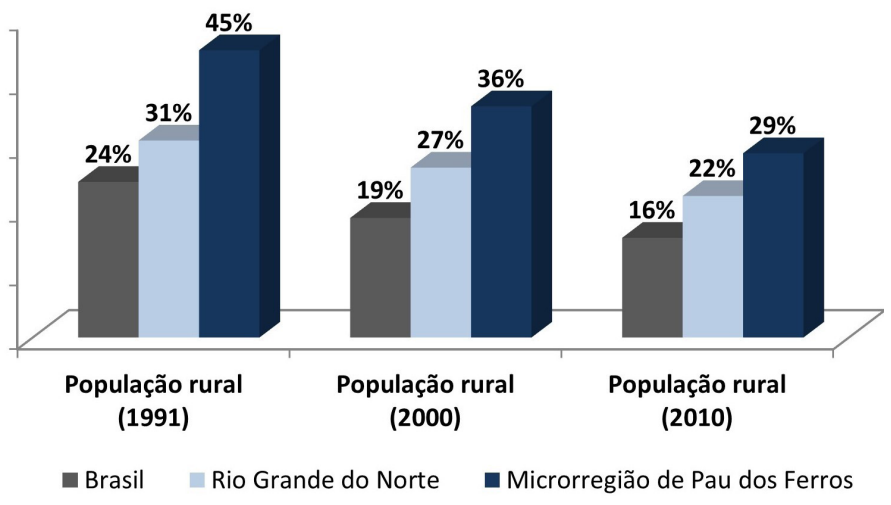

Fig. 5. Comparativo da População Rural (\%) 1990-2010 (adaptado de IBGE, 1991, 2000, 2010).

dos Ferros é $54.846 .000,00 \mathrm{~m}^{3}$, e o seu volume morto é $1.092 .710,00 \mathrm{~m}^{3}$.

Assim, por meio da Figura 6, constata-se que em 2011 o volume da Barragem de Pau dos Ferros passou a decrescer e atingiu o volume morto em dezembro de 2014, condição que permaneceu até abril de 2018, quando houve uma recuperação de acumulação. O estado de volume morto voltou em março de 2019, sendo superado apenas em março de 2020. Em 2016, ano foco deste estudo, a quantidade de água armazenada era nula, o que representa uma situação de extrema criticidade. A Figura 7 mostra a situação da Barragem de Pau dos Ferros em 2016.

Apurou-se que a construção da Barragem Pau dos Ferros foi concluída pelo DNOCS em 1967 (ANA, 2017). Apesar do transcurso de 53 anos, não foram identificadas obras de manutenção, como desassoreamento, recuperação de mata no entorno e de ampliação de capacidade. Destacase que, além da sedimentação de material durante todo este tempo, que reduz o volume de armazenamento, a população de Pau dos Ferros/ $\mathrm{RN}$, em 1967, residente na zona urbana era bem menor do que a observada atualmente.

Dessa forma, para atender às necessidades básicas da população pauferrense, foram adotadas medidas emergenciais, como perfuração de poços artesianos e a implantação de uma adutora de engate rápido.

DadoscoletadosnaSecretariade Desenvolvimento Rural de Pau dos Ferros/RN (2016) mostram que a perfuração de poços teve intensificação a partir de 2013 com o objetivo de complementar o abastecimento da adutora de engate rápido. A Figura 8 retrata as caixas d'água associadas à poços perfurados em praças públicas do município de Pau dos Ferros/RN, em que o acesso poderia ser feito por todos os indivíduos.

Embora as condições geofísicas (solo cristalino e água com alto teor de salinidade) do RN não favoreçam a utilização, em larga escala, da

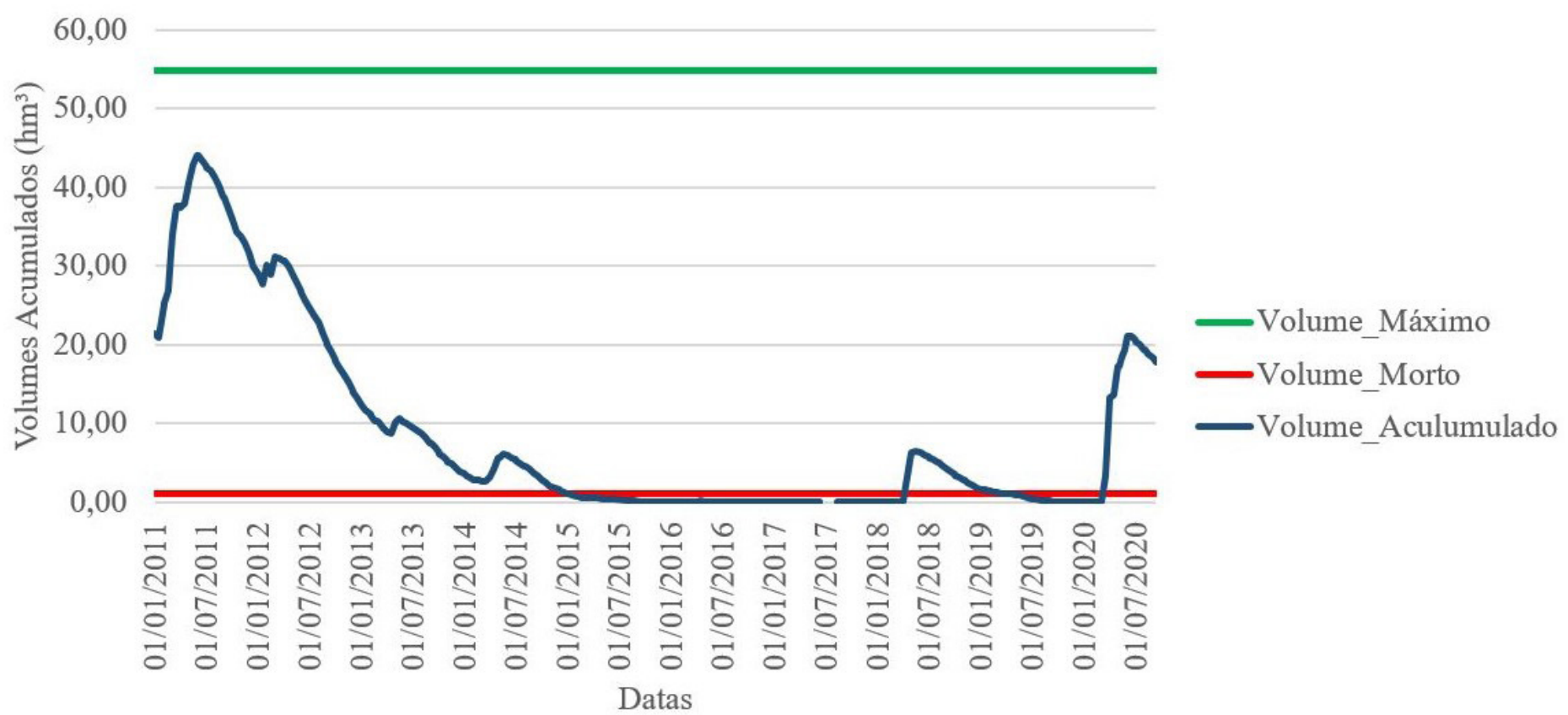

Fig. 6. Evolução Volumétrica da Barragem de Pau dos Ferros (adaptado de ANA, 2020a). 


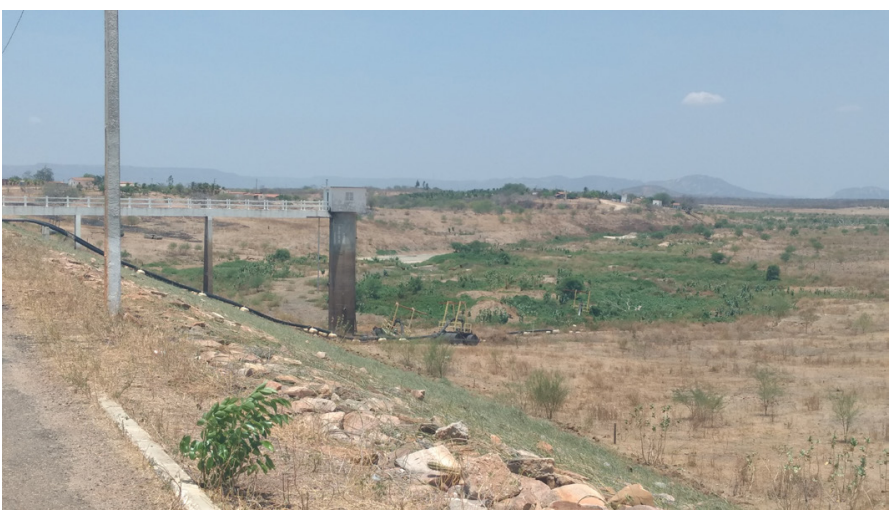

Fig. 7. Barragem de Pau dos Ferros/RN em novembro de 2016.

perfuração de poços, observa-se que as gestões municipais recorreram bastante ao expediente, em alguns casos, provavelmente, para se resguardar de críticas mais acentuadas por parte da opinião pública.

A Tabela 1 apresenta o panorama de perfuração de poços públicos no município de Pau dos Ferros, incluindo zona rural e urbana, entre os anos de 2013 e 2015.

Analisando a Tabela 1, identifica-se que em 2015 o número de poços perfurados foi aproximadamente o dobro da quantidade de 2013. No entanto, há muitos poços secos ou que não foram instalados devido à baixa vazão. Verificou-se que, para poços particulares, não existe um controle.

Enfatiza-se que a estratégia de perfuração de poços por parte do Poder Público não era muito usual, especialmente nos municípios da Microrregião de Pau dos Ferros, em função da incompatibilidade geológica e dos altos custos envolvidos, o que foi modificado a partir de 2011. Basta mencionar que no quadriênio de 2011 a 2014, a Secretaria do Meio Ambiente e dos Recursos Hídricos do Rio Grande do Norte (SEMARH) instalou 223 poços em todo o estado e indicou a realização de locações de 420 poços no ano de 2015, sendo 250 no Alto Oeste

Tabela 1. Quantidade de poços perfurados e situação entre os anos de 2013 e 2015 (Adaptada de Secretaria de

Desenvolvimento Rural de Pau dos Ferros, 2016).

\begin{tabular}{ccc}
\hline Ano & Quantidade & Situação \\
\hline 2013 & 20 & 12 instalados; 7 secos; 1 não \\
instalado \\
2014 & 3 & 2 instalados \\
2015 & 39 & $\begin{array}{c}6 \text { instalados; } 24 \text { secos; } 9 \text { não } \\
\text { instalados }\end{array}$ \\
\hline
\end{tabular}
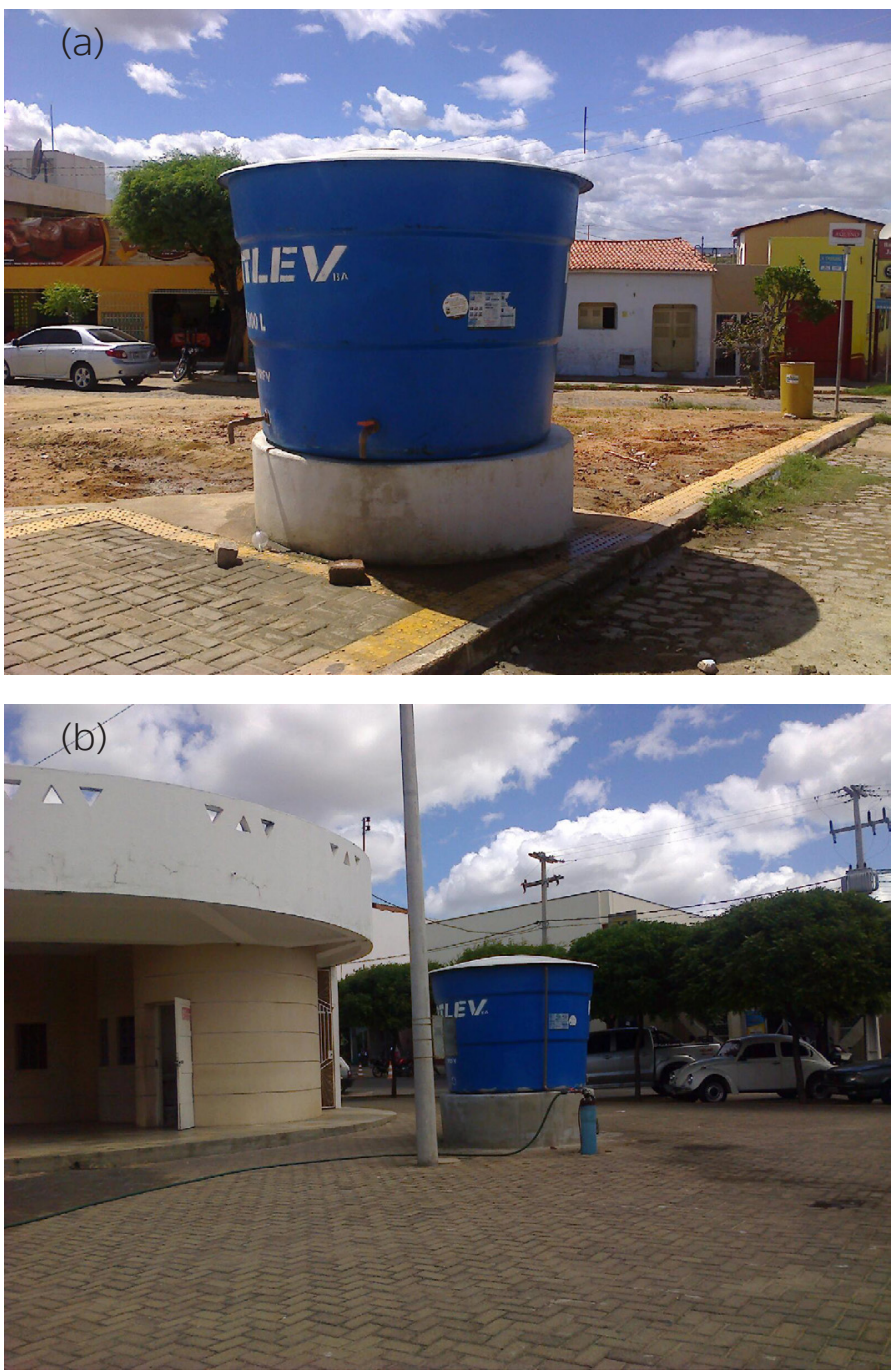

Fig. 8. Caixas d'água de polímero na Praça da Matriz (a) e Praça São Benedito (b) - Pau dos Ferros/RN.

Potiguar, dos quais, cerca de 16\% foram perfurados em Pau dos Ferros/RN (SEMARH, 2015).

A implantação de sistemas adutores completa o rol das ações mais representativas executadas pelo Estado em relação a seca de 2012 a 2017 na Microrregião de Pau dos Ferros. Para o caso de Pau dos Ferros/RN foi instalada uma Adutora Emergencial de Engate Rápido, por meio de uma derivação da Adutora Alto Oeste, que captava água de Santa Cruz (SEMARH, 2016).

Os testes da Adutora Emergencial de Engate Rápido aconteceram em setembro de 2014 e seu funcionamento foi iniciado em outubro deste mesmo ano (IGARN, 2014), por meio do sistema de rodízio, no qual os bairros de Pau dos Ferros/ RN eram divididos em três setores (IGARN, 2015).

A Figura 9 expõe a Adutora Emergencial de Engate Rápido que abastecia Pau dos Ferros/RN 


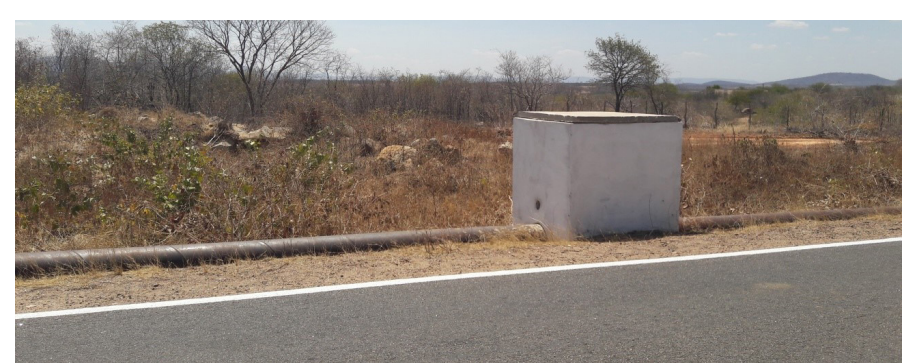

Fig. 9. Adutora emergencial de engate rápido Santa Cruz/RN - Pau dos Ferros/RN.

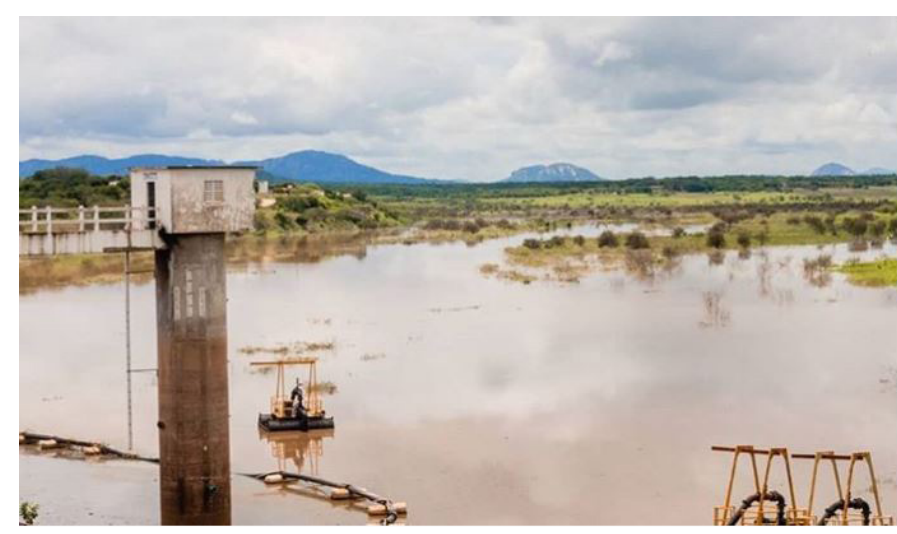

Fig. 10. Barragem de Pau dos Ferros/RN em março de 2020 (IGARN, 2020).

até o ano de 2020. Após aproximadamente 4 anos, a Barragem de Pau dos Ferros voltou a abastecer a cidade em abril de 2020 (IGARN, 2020), em função de seu volume armazenado (Figura 10).

O volume acumulado em 2020 é considerável, se comparado ao de 2016, mas necessita de uma boa gestão de recursos hídricos para que possa atender aos usos previstos com efetividade e em um período de tempo planejado, uma vez que ações paliativas, como é o caso de Adutora Emergencial de Engate Rápido e perfuração de poços, embora contribuam muito para o acesso à água, não se configuram como promotoras da segurança hídrica a longo prazo. Dessa forma, se faz necessário, dentre outras medidas: estabelecer regras de usos para o reservatório principal, regularizar usuários, executar um bom gerenciamento da distribuição hídrica, reduzir o número de perdas, conscientizar a população para uso racional.

\section{Considerações finais}

Por meio dos dados analisados, diagnosticouse a perda da representatividade demográfica e econômica das áreas rurais na composição estrutural dos municípios analisados frente ao aumento da importância das áreas urbanas. $\mathrm{O}$ que se observou em termos gerais nos municípios que compõem a microrregião analisada no período analisado foram: i) redução da população rural e; ii) redução da participação do PIB agropecuário em relação ao PIB Total Municipal. A queda do setor agropecuário apresentado na região estudada não pode ser atribuída apenas ao fator climático, pois este é um fenômeno natural que ocorre de forma periódica na região, ocasionando longos períodos de estiagem. Grande parte dessas mudanças estruturais na região implicam a falta de um planejamento urbano-regional atrelado a políticas públicas que propiciem o desenvolvimento social e o crescimento econômico da região fundamentados na convivência com o fator clima.

Percebe-se que as medidas de combate à seca, propostas pela solução hídrica resultante de diversas ações governamentais, contribuíram para redução da problemática água, mas, não apresentaram resultados efetivos. Para atender demandas de maneira parcial, foram adotadas medidas emergenciais, como as verificadas no município de Pau dos Ferros/RN: adutora emergencial de engate rápido e perfuração de poços artesianos.

Logo, a gestão eficaz e eficiente dos recursos hídricos e a celeridade na implantação de projetos que venham a colaborar para a redução dos impactos ocasionados pelo déficit hídrico, concomitante com políticas públicas nacionais que se efetivem na região, fazem-se necessárias.

\section{Referências bibliográficas}

$A B$ 'SABER, A. Os domínios de natureza no Brasil: potencialidades paisagísticas. São Paulo: Ateliê Editorial, 2003.

AGÊNCIA NACIONAL DE ÁGUAS (ANA). Reservatórios do semiárido brasileiro: hidrologia, balanço hídrico e operação. Brasília: ANA, 2017.

AGÊNCIA NACIONAL DE ÁGUAS (ANA). Sistema de Acompanhamento de Reservatórios (SAR). Dados Históricos de 2011 a 2020. Brasília: ANA, 2020a. 
AGÊNCIA NACIONAL DE ÁGUAS (ANA). Monitor de Secas. Brasília: ANA, 2020b.

ALBUQUERQUE JÚNIOR, Durval Muniz de. As imagens retirantes. A constituição da figurabilidade da seca pela literatura do final do século XIX e do início do século XX. Varia Historia, v. 33, n. 61, p. 225-251, 2017.

ARTICULAÇÃO NO SEMIÁRIDO BRASILEIRO (ASA). Programa Um Milhão de Cisternas. Disponível em: 〈http://www.asabrasil.org.br/acoes/p1mc>. Acessado em: 10 set. 2020.

ATLAS DO DESENVOLVIMENTO HUMANO NO BRASIL. Atlas do IDHM. Disponível em: <http:// www.atlasbrasil.org.br/2013/pt/consulta/>. Acesso em: 28 de outubro de 2016.

BLECHER, B. A tecnologia que domou os desertos. Disponivel em: <http://revistagloborural.globo. com/Revista/Common/O,EMI292798-18281,00-A+ TECNOLOGIA+QUE+DOMOU+OS+DESERTOS.html>. Acessado em: 10 de novembro de 2016.

BRASIL. Decreto $\mathrm{n}^{\circ} \mathbf{1 . 9 4 6}$, de 28 de junho de 1996. Cria o Programa Nacional de Fortalecimento da Agricultura Familiar - PRONAF, e dá outras providências. Disponível: <http://www.planalto.gov. br/ccivil_03/decreto/D1946.htm>. Acesso em: 15 set. 2020.

BRASIL. Lei $\mathbf{n}^{\circ} \mathbf{1 0 . 6 9 6}$, de 2 de julho de 2003. Dispõe sobre a repactuação e o alongamento de dívidas oriundas de operações de crédito rural, e dá outras providências. Disponível: <http://www. planalto.gov.br/ccivil_03/LEIS/2003/L10.696.htm>. Acesso em: 15 set. 2020.

DANTAS, J. R. Q. As cidades médias no desenvolvimento regional: um estudo sobre Pau dos Ferros (RN). Tese (Doutorado em Ciências Sociais) Programa de Pós-Graduação em Ciências Sociais, Universidade Federal do Rio Grande do Norte, 2014.

DANTAS, J. R. Q.; CLEMENTINO, M. L. M.; FRANÇA,
R. S. A Cidade Média Interiorizada: Pau Dos Ferros no Desenvolvimento Regional. In: XII Seminário Internacional RII, 2014, Salvador. Anais do XIII Seminário Internacional RII. Salvador: SEl/Bahia, 2014. v. único. p. 1-21.

DANTAS, J. R. Q.; FRANÇA, R. S. Desenvolvimento humano e hierarquia urbana: um estudo do IDHM nos municípios Potiguares. Trabalho apresentado no GT 4 Dinâmicas Socioeconômicas no Território III Seminário de Desenvolvimento Regional, Estado e Sociedade - SEDRES, Blumenau (SC), ocorrido entre 14 e 16 de setembro de 2016.

GRUPO DE TRABALHO PARA DESENVOLVIMENTO DO NORDESTE (GTDN). Uma política de desenvolvimento econômico para o Nordeste. Recife/PE SUDENE, 1959. Disponível em: <https:// web.bndes.gov.br/bib/jspui/handle/1408/17760>. Acesso em: 17 set. 2020.

IBGE - Instituto Brasileiro de Geografia e Estatística. Censo demográfico 1990. Rio de Janeiro: IBGE, 1991.

IBGE - Instituto Brasileiro de Geografia e Estatística. Censo demográfico 2000. Rio de Janeiro: IBGE, 2000.

IBGE - Instituto Brasileiro de Geografia e Estatística. Censo demográfico 2010. Rio de Janeiro: IBGE, 2010.

IBGE - Instituto Brasileiro de Geografia e Estatística. Mapas regionais. Semiárido brasileiro. 2018. Disponível em: <https:// www.ibge.gov.br/geociencias/cartas-e-mapas/ mapas-regionais/15974-semiarido-brasileiro. html?=\&t=acesso-ao-produto $>$. Acesso em: 17 jun. 2020.

IBGE - Instituto Brasileiro de Geografia e Estatística. Cidades. 2020. Disponível em https://cidades.ibge. gov.br/. Acesso em: 17 jun. 2020.

IBGE - Instituto Brasileiro de Geografia e Estatística. Produto Interno Bruto do Municípios 2002- 
2017. In: IBGE. Sidra: sistema IBGE de recuperação automática. Rio de Janeiro, 2011a. Disponível em: <https://sidra.ibge.gov.br/pesquisa/pib-munic/ tabelas $>$. Acesso em: 10 de jan. 2020.

IGARN, Imagem da Barragem de Pau dos Ferros/ RN, 2020. Disponível em: <https://www.instagram. com/p/B97nZPOIhx1/>. Acesso em: 17 set. 2020.

INSTITUTO DE GESTÃO DAS ÁGUAS DO RIO GRANDE DO NORTE (IGARN). Adutora de Pau dos Ferros deve entrar em operação nos próximos dias. 2014.

INSTITUTO DE GESTÃO DAS ÁGUAS DO RIO GRANDE DO NORTE (IGARN). Em Pau dos Ferros, Governadora confere funcionamento da adutora de Engate Rápido. 2014.

INSTITUTO DE GESTÃO DAS ÁGUAS DO RIO GRANDE DO NORTE (IGARN). Rodízio em Pau dos Ferros terá alteração em seu cronograma. 2015.

INSTITUTO DE GESTÃO DAS ÁGUAS DO RIO GRANDE DO NORTE (IGARN). Bacia Apodi/Mossoró. 2017.

INSTITUTO DE GESTÃO DAS ÁGUAS DO RIO GRANDE DO NORTE (IGARN). Pau dos Ferros volta a ser abastecida pela barragem. 2020 .

MALVEZZI, R. Semi-Árido: uma visão holística. Brasília: Confea, 2007.

SECRETARIA ESTADUAL DO MEIO AMBIENTE E DOS RECURSOS HÍDRICOS DO RIO GRANDE DO NORTE (SEMARH). Governo do RN anuncia a perfuração de 300 poços artesianos em 2015. 2015. Disponível em: <http://tribunadajustica.com. br/governo-do-rn-anuncia-a-perfuracao-de-300pocos-artesianos-em-2015/>. Acesso em 16 jun. 2020.

SECRETARIA ESTADUAL DO MEIO AMBIENTE E DOS RECURSOS HÍDRICOS DO RIO GRANDE DO NORTE (SEMARH). Pau dos Ferros recebe aumento na oferta de água de mais $\mathbf{3 5}$ mil litros por hora. 2016.
SILVA, R. M. A. Entre dois paradigmas: combate à seca e convivência com o semi-árido. Sociedade e estado, v. 18, n. 1-2, p. 361-385, 2003.

SILVA, R. M. A. Entre o Combate à Seca e a Convivência com o Semi-Árido: políticas públicas e transição paradigmática. Revista Econômica do Nordeste, Fortaleza, v. 38, n. 3, p. 466- 485, jul-set. 2007.

SOUTO, L. V.; SOUSA JUNIOR, A. M.; LIMA JÚNIOR, F. O. Economia e Aspectos da Urbanização na Microrregião de Pau dos Ferros, Rio Grande do Norte, Brasil. Revista Brasileira de Assuntos Regionais e Urbanos, Goiânia, v. 5, n. 2, p. 182-198, jul./dez. 2019.

SUPERINTENDÊNCIA DO DESENVOLVIMENTO DO NORDESTE (SUDENE). Resolução $n^{0}$ 115/2017. Aprova a Proposição ${ }^{\circ} 113 / 2017$, que acrescenta municípios a relação aprovada pela Resolução CONDEL n 107, e 27 de julho de 2017. Disponível em: <http://sudene.gov.br/images/arquivos/ conselhodeliberativo/resolucoes/resolucao11523112017-delimitacaodosemiarido.pdf >. Acesso em 16 jun. 2020. 
Publicação organizada pelo Programa de

Mestrado Profissional Stricto Sensu em

Engenharia Civil da Universidade São Judas

Volume 03 - Edição 01

Janeiro - Dezembro de 2020

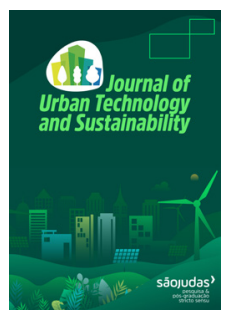

\title{
A produção habitacional do programa MCMV no município de São Paulo: critérios de localização adotados pelos produtores e impactos na estrutura urbana e na qualidade de vida dos moradores
}

\author{
Edson L. Ribeiroa,", José A. R. Silveirab \\ ${ }^{a}$ Engenharia Urbana - Secretaria Nacional da Habitação - SNH/ MDR, Brasília, Brasil. \\ ${ }^{b}$ Programa de Pos-Graduação em Arquitetura e Urbanismo - LAURBE / PPGAU - CT - Universidade Federal da Paraíba, João Pessoa, Brasil.
}

Informações

Recebido 8 Outubro 2020

Manuscrito revisado recebido

18 Novembro 2020

Aceito 28 Novembro 2020

Palavras-chave

Minha Casa, Minha Vida

Estrutura urbana

Qualidade de vida

\section{Resumo}

O estudo avalia a concentração da produção habitacional do Programa Minha Casa, Minha Vida no município de São Paulo em suas várias faixas de renda familiar, estudando-se a sua relação particularmente aos seguintes aspectos: a) distância do centro tradicional; b) distância dos novos centros geradores de emprego; c) oferta local de oportunidades de trabalho e renda e d) índice de violência urbana, comparando-se ainda com resultados de outra pesquisa sobre a satisfação com a qualidade de vida urbana por setor urbano na cidade. Embora tenha ficado clara a correlação inversa entre a concentração local da produção habitacional em relação à proximidade das oportunidades de trabalho e renda, outros índices comparados não apresentaram os mesmos resultados. Também ficou constatado que, no âmbito do município, a produção longínqua dos conjuntos habitacionais não produziu significativa dispersão urbana, tendo os mesmos, em função do uso da verticalização, ocupado predominantemente terrenos e glebas intersticiais (vazios urbanos).

\section{Housing production in the MCMV program in the city of São Paulo: location criteria adopted by contractors and impacts on urban structure and quality of life for residents}

\section{Article info \\ Received 8 Octubre 2020 \\ Received in revised form 19 November 2020 \\ Accepted 28 November \\ 2020 \\ Keywords \\ Minha Casa, Minha Vida \\ Urban structure \\ Quality of life}

\begin{abstract}
The study assesses the concentration of housing production of the Minha Casa, Minha Vida Program in the municipality of São Paulo in its various ranges of family income, studying its relationship particularly with the following aspects: a) distance from the traditional center; b) distance from new job-generating centers; c) local offer of job and income opportunities and d) urban violence index, comparing with results of another survey on satisfaction with the quality of urban life by urban sector in the city. Although it was clear the inverse correlation between the local concentration of housing production in relation to the proximity of work and income opportunities, other compared indexes did not show the same results. It was also found that, within the scope of the municipality, the distant production of the housing complexes did not produce significant urban dispersion, having, due to the use of verticalization, occupied predominantly land and interstitial plots (urban voids).
\end{abstract}

\section{Producción de vivienda en el programa MCMV en la ciudad de São Paulo: criterios de ubicación adoptados por constructores e impactos en la estructura urbana y calidad de vida de los residentes}

\section{Información}

Recibido 8 Octubre 2020

Manuscrito revisado recibido

19 Noviembre 2020

Aceptado 28 Noviembre

Palabras clave

Minha Casa, Minha Vida

Estructura urbana

Calidad de vida

\section{Resumen}

El estudio evalúa la concentración de la producción habitacional del Programa Minha Casa, Minha Vida en el municipio de São Paulo en sus diversos rangos de ingresos familiares, estudiando su relación particularmente con los siguientes aspectos: a) distancia del centro tradicional; b) distancia de nuevos centros generadores de empleo; c) oferta local de oportunidades laborales y de ingresos y d) índice de violencia urbana, comparándolo con los resultados de otra encuesta sobre satisfacción con la calidad de vida urbana por sector urbano de la ciudad. Si bien quedó clara la correlación inversa entre la concentración local de la producción de vivienda en relación con la proximidad de oportunidades laborales y de ingresos, otros índices comparados no alcanzaron mismos resultados. También se encontró que, en el ámbito del municipio, la producción distante de los conjuntos habitacionales no produjo una dispersión urbana significativa, habiendo, debido al uso de la verticalización, ocupado predominantemente terrenos y solares intersticiales (vacíos urbanos).

\footnotetext{
* Autor correspondente em: Secretaria Nacional da Habitação - SNH/ MDR.

E-mail: edlribeiro@gmail.com (Edson L. Ribeiro)
}

https://doi.org/10.47842/juts.v3i1.25

ISSN: 2675-780X 


\section{Introdução}

Em uma análise bastante recente da política habitacional estatal no Brasil, verifica-se que desde a incapacidade do Sistema Financeiro da Habitação-SFH de atender a provisão habitacional na faixa de renda mais crítica e, a partir dos anos 1980, com o colapso do SFH e a descontinuidade na produção e oferta de habitação popular, associado ainda com o aumento da pressão populacional no centro urbano, observou-se que o processo de favelização, ocupações informais, inclusive em áreas de risco continuou a aumentar nas grandes cidades. No período da segunda metade da década de 1980 até a passagem do século, a produção habitacional social formal esteve quase que limitada aos segmentos de renda intermediaria, devido à pouca iniciativa direta do governo federal no período, sendo caracterizada por um período de intensificação da produção informal, em áreas ocupadas ou em loteamentos periféricos.

Em 2001, foi promulgado o Estatuto da Cidade, que é resultado da luta árdua dos movimentos de reforma urbana e de lutas pela moradia. Nesta lei, se consagra o conceito do direito à cidade e da submissão do direito de propriedade à sua função social. Em 2003, foi criado o Ministério das Cidades, com a proposta de uma visão ampliada e integrada sobre as questões urbanas, onde já viviam mais de $80 \%$ da população nacional. Além do seu aspecto técnico-institucional, a proposta de funcionamento de um sistema colegiado, representado pelo Conselho das Cidades, com competência propositiva para as ações desse Ministério, também pode ser entendido como um avanço positivo em uma forma mais participativa de gestão, apesar das dificuldades inerentes a esse funcionamento.

Em 2004, foi aprovada a Política Nacional de Habitação-PNH e, a partir de seus princípios, foi concebido o Sistema Nacional de Habitação e, dentre esse, especialmente o Sistema Nacional de Habitação de Interesse Social-SNHIS, criado pela lei $11124 / 2005$. No funcionamento do SNHIS se previa o pacto federativo, e o compromisso pelos entes que aderissem nos três níveis (união, estados e municípios), em garantir um Fundo de Habitação, um Conselho Gestor do Fundo de Habitação e elaborar e obedecer a um Plano de Habitação. Esse funcionamento estimularia a cooperação federativa, a cultura da participação (através dos Conselhos) e a cultura do Planejamento, pela obrigatoriedade do Plano. Além disso, seus objetivos principais era o atendimento de provimento habitacional para as faixas de renda mais representativas no déficit habitacional, à época, considerada as faixas de renda de até três salários-mínimos. Também eram previstas no programa, ações de urbanização de favelas e de assistência técnica. Seu funcionamento, apesar de lento e não conseguir atingir a todos os municípios mais carentes, se caracterizava por um avanço considerado na condução democrática e técnica do problema de habitação, especialmente para as faixas de renda mais baixa e com menor acessibilidade à habitação digna.

\section{O Programa MCMV}

Com o advento da crise econômica mundial de 2008 e 2009, foi lançado o programa Minha Casa, Minha Vida, que visava, simultaneamente, reduzir o déficit quantitativo habitacional e dinamizar a economia, gerando empregos e renda, através da atividade de construção de habitação de interesse social. Tal programa visava atingir todo o espectro da chamada faixa de habitação social. Dessa forma, tinha algumas variantes, chamadas comumente de faixas 1, 2 e 3, onde a chamada faixa 1 era a faixa mais crítica (0 a 3 Salários mínimos) e tinham subsídios mais significativos, garantidos pelo Fundo de Arrendamento Residencial (FAR): seu pagamento mensal era limitado a um pequeno percentual da renda mensal, tendo seus resíduos cobertos por Fundo garantidor. Nessa faixa, o beneficiário não escolhe o imóvel, mas o mesmo é sorteado entre os inscritos que atendem as condições exigidas.

A chamada faixa 2, utilizando-se recursos do FGTS teria um pequeno subsídio fixo, juros mais baixos e o Fundo Garantidor ofereceria certa segurança quanto a eventos de desemprego ou renda cessante; e a Faixa 3, com recursos do FGTS onde não haveria subsídios, apenas melhores garantias e juros menos onerosos.

Por questões de limitação orçamentaria e por 
vontade política de reforçar a validade do Programa Minha Casa, Minha Vida, já consagrado pela sua grande capacidade de produção quantitativa de unidades habitacionais, o SNHIS, apesar de este dever ser o Sistema mais permanente e estruturante, foi gradativamente legado a um segundo plano e, posteriormente, quase esquecido, especialmente nas ações de provimento habitacional. Além disso, deve ser destacado que o SNHIS tinha sido criado e colocado em prática como resposta às reivindicações históricas dos movimentos sociais.

Em relação ao aspecto quantitativo de sua produção, não há dúvidas que sua contribuição foi bastante eficiente, ultrapassando todos os períodos anteriores, inclusive a produção considerável no SFH, durante o período do governo militar que segundo Arretche apud Dutra (2012) atingiu 4.300.000 unidades habitacionais no país. Observando ainda que nesses programas anteriores, as faixas de baixíssima renda (equivalente a faixa 1) eram pouco atingidas.

\section{A produção habitacional através do MCMV em São Paulo - SP}

A produção habitacional, pelo MCMV em suas várias etapas, de 2009 a 2015, no município de São Paulo - SP, também se caracterizou pela grande quantidade de unidades habitacionais produzidas, como pode ser observado na síntese a seguir:

Igualmente ao observado nos programas do governo militar, com o foco na casa própria, esse programa provia um bem privado, e não exatamente um serviço público. E da mesma forma, sua lógica seguia a regra de mercado: mantinhase o lucro dos produtores reduzindo-se os custos, com prejuízos notáveis na qualidade habitacional e na inserção urbana. Apesar do grande êxito quantitativo do programa, o que em princípio é positivo, tendo em vista a magnitude do déficit quantitativo brasileiro, ele recebeu várias críticas em relação ao seu aspecto qualitativo, tanto no aspecto da unidade habitacional, quanto dos conjuntos e empreendimentos e, especialmente no que diz respeito à sua inserção urbana.

Temporalmente, o número de contratação e execução dessas unidades habitacionais, no município considerado, teve seus picos de produção habitacional nos anos 2010 e 2014. Observou-se também que, no município, a produção destinada às faixas 2 e 3 foi maior que a destinada à faixa 1 , considerada a mais crítica no déficit habitacional. De forma geral a produção habitacional na faixa 2 predominou sobre a faixa 1 em todos os anos. No caso da faixa 3, apenas os resultados de 2013, 2014 e 2015 não foram maiores que os da faixa 1. Ver tabela 3.

No caso de São Paulo, como em todas as metrópoles e cidades de médio e grande porte no Brasil, também se observou tal fenômeno. Os empreendedores do Programa mantinham seus lucros pretendidos buscando reduzir os seus custos. Dentre as providências neste sentido, especialmente foi utilizada a redução dos custos de aquisição da terra.

Observando-se inicialmente os bairros de maior implantação de empreendimentos e os fatores

Tabela 1. Unidades habitacionais contratadas através do Programa MCMV no Brasil entre 2009 e 2016 (CAIXA, 2017).

\begin{tabular}{ccccccccc}
\hline Modalidade & $\mathbf{2 0 0 9}$ & $\mathbf{2 0 1 0}$ & $\mathbf{2 0 1 1}$ & $\mathbf{2 0 1 2}$ & $\mathbf{2 0 1 3}$ & $\mathbf{2 0 1 4}$ & $\mathbf{2 0 1 5}$ & $\mathbf{2 0 1 6}$ \\
\hline Faixa 1 & 143894 & 338847 & 104311 & 389073 & 557961 & 175260 & 16890 & 27968 \\
Empresas & 143484 & 260644 & 83358 & 306847 & 419940 & 106670 & 1188 & 1738 \\
Rural & 101 & 5716 & 12295 & 41124 & 56899 & 48921 & 9064 & 15411 \\
Urbana & 309 & 7715 & 2988 & 7751 & 16382 & 18737 & 6064 \\
Cid < 50 & 0 & 63722 & 5670 & 32751 & 64740 & 0 & 10819 \\
Faixa 2 & 98593 & 277171 & 325953 & 311965 & 288708 & 289715 & 344729 & 144560 \\
Faixa 3 & 43818 & 102805 & 77935 & 97711 & 93799 & 37609 & 40526 & 29595 \\
Total p/ ano & 286305 & 718823 & 508199 & 798747 & 940468 & 502584 & 402145 & 202123 \\
\hline
\end{tabular}

TOTAL 2009-2016: 4359394 
Tabela 2. Unidades habitacionais contratadas e concluídas, por modalidade, no município de São Paulo/SP entre 2009 e 2015 (SISHAB/SNH, 2019).

\begin{tabular}{|c|c|c|c|}
\hline Modalidade & $\begin{array}{l}\text { Faixa } \\
\text { renda }\end{array}$ & Contratadas & Concluídas \\
\hline Entidades & Faixa 1 & 7000 & 3192 \\
\hline FAR - Empresas & Faixa 1 & 7168 & 780 \\
\hline $\begin{array}{l}\text { FAR Urbanização } \\
\text { (vinculadas) }\end{array}$ & Faixa 1 & 5528 & 280 \\
\hline \multicolumn{2}{|c|}{ Total Faixa 1} & 19696 & 4252 \\
\hline CCFGTS & Faixa 2 & 34232 & 32507 \\
\hline CCFGTS & Faixa 3 & 25707 & 21239 \\
\hline \multicolumn{2}{|l|}{ TOTAL } & 79635 & 63126 \\
\hline
\end{tabular}

mais diretamente relacionados com a (des) valorização do solo urbano local, conjeturouse que, dentre os locais mais utilizados para a construção dos mesmos, em função dos custos estariam basicamente os seguintes: a) terrenos mais distantes do centro urbano e áreas de oferta de oportunidades; b) terrenos localizados em áreas de baixa oferta local de oportunidades de trabalho, emprego e renda e c) terrenos localizados em áreas de maiores índices de violência urbana.

Dessa maneira, entre os empreendimentos executados no município de São Paulo, foram testadas essas três condições, com forte capacidade de influir negativamente no valor do imóvel, tornando-os mais "atrativos" para os empreendedores.

\section{Metodologia}

Como metodologia se buscou avaliar a relação que havia entre as áreas de maior produção de unidades habitacionais no município e as citadas condições: 1) valor do solo; 2) distância do centro; 3) oferta local de oportunidades e 4) índice de violência). Para o critério "distância do centro", se dividiu a produção habitacional por faixas de distância (0 a 5, 5 a 10 km....) do centro urbano tradicional (a partir do Vale do Anhangabaú). Foi também utilizado o critério de distância em relação ao novo centro de tendência de oferta de oportunidades de trabalho mais bem remunerado (tomando-se como referência o quadrilátero: Berrini - Faria Lima), considerado o novo centro "pósmoderno" da cidade, em função de sua crescente capacidade de geração de oportunidades.

Para o critério da oferta local de oportunidades de trabalho, emprego e renda, se correlacionou a produção habitacional relativa por bairro (\% em relação à produção total) e a oferta relativa de postos de trabalho por bairro (\% da oferta em relação à oferta total no município). E, finalmente, em relação ao aspecto da violência urbana, adotouse o critério universal da taxa de homicídios (no. de homicídios/100.000 habitantes) por bairro e a sua relação com a produção e oferta de unidades habitacionais no MCMV. Tais resultados também foram relacionados com aspectos da estrutura urbana, tal como a dispersão territorial e a percepção coletiva da qualidade de vida urbana por setor urbano.

\section{Resultados obtidos}

De maneira geral, os setores que mais receberam unidades habitacionais do Programa Minha Casa, Minha Vida na cidade foram os setores leste, norte e sul, notadamente em suas áreas mais distantes e caracterizadas pela ocupação predominante de populações de baixa renda.

O setor da cidade que mais recebeu unidades habitacionais do programa foi o setor Leste $(56,81 \%)$, seguido do setor Norte $(20,34 \%)$ e o setor Sul (13,07\%) que, apesar de sua diversidade tipológica, constituem zonas urbanas com

Tabela 3. Unidades habitacionais contratadas por faixa de renda (todas as modalidades) e por ano no município de São PauloSP entre 2009 e 2015 (GI/SNH, 2018).

\begin{tabular}{lccccccc}
\hline Faixa & $\mathbf{2 0 0 9}$ & $\mathbf{2 0 1 0}$ & $\mathbf{2 0 1 1}$ & $\mathbf{2 0 1 2}$ & $\mathbf{2 0 1 3}$ & $\mathbf{2 0 1 4}$ & $\mathbf{2 0 1 5}$ \\
\hline Faixa 1 & 680 & 4868 & 500 & 2432 & 3612 & 4754 & 2850 \\
Faixa 2 & 4375 & 7130 & 4608 & 2932 & 4683 & 4819 & 5685 \\
Faixa 3 & 5269 & 6733 & 4995 & 3593 & 2159 & 2112 & 846 \\
\hline
\end{tabular}




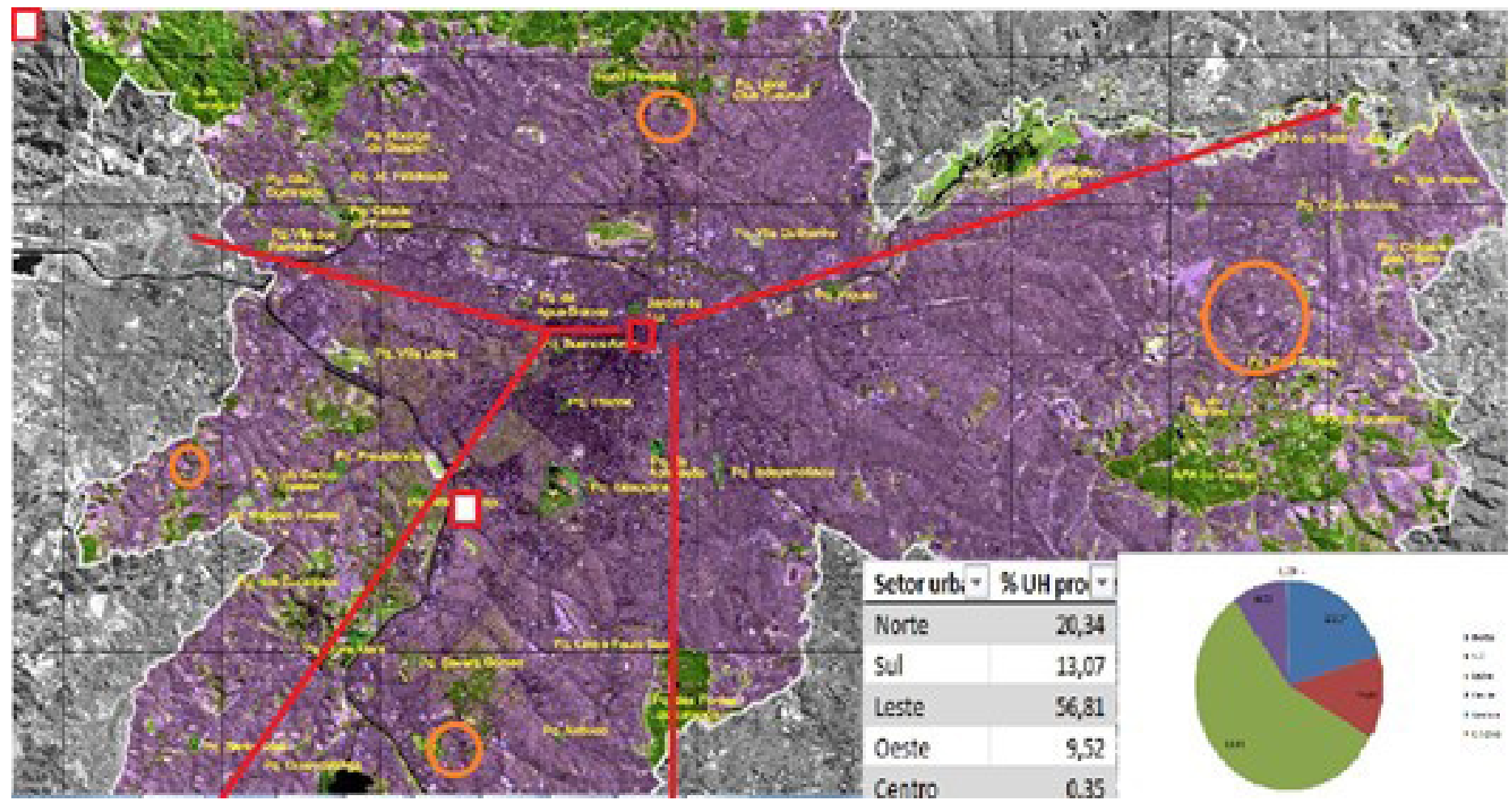

Fig. 1. Proporção da produção de unidades habitacionais no MCMV por setor urbano do município de São Paulo - SP (adaptado de Atlas Ambiental PMSP, 2019).

predominância de habitações populares. Pode ser observado que entre estes setores urbanos, a área Leste, exatamente a mais distante dos centros concentrou maior número de UH produzidas. O setor Oeste, mais próximo das áreas mais geradoras de emprego e renda e, portanto, com solo um pouco mais caro, teve participação relativamente modesta (9,52\%). Mas, foi o setor central, com apenas 0,35\% das UH implantadas que representou o setor menos utilizado para esse fim, o que representa uma anomalia e um prejuízo claro à harmonia estrutural, funcional e social da cidade, uma vez que este representa uma área de grande oferta oportunidades de trabalho e de bens e serviços públicos e privados, constituindo-se portanto uma das áreas de maior qualidade para a habitação.

\section{a. Distâncias em relação aos setores urbanos maiores geradores de oportunidades de trabalho e renda}

Tomando-se inicialmente o critério de distância do centro tradicional e também a distância das novas áreas de geração de emprego e renda (setor sudoeste da área pericentral), observou-se o seguinte resultado: A produção de UH pelo MCMV foi relativamente pequena nas faixas de até $10 \mathrm{~km}$ em relação ao centro tradicional, notadamente na faixa entre 0 e $5 \mathrm{~km}$. A faixa de maior produção foi entre 16 e $20 \mathrm{~km}$, voltando a diminuir na faixa entre 21 e 25 km. Provavelmente essa redução está mais em função de certa inviabilidade mercadológica, especialmente para as faixas 2 e 3 , cujos picos ocorreram respectivamente na faixa $16-20 \mathrm{~km}$ e 11-15 km. Nota-se, no entanto que, para a faixa 1, exatamente a que se refere a famílias com menores recursos de mobilidade, a produção foi crescente à medida da distância do centro, atingindo o seu pico exatamente na faixa mais distante. Uma das poucas facilidades para os residentes na faixa mais distante do centro principal e também dos centros secundários, notadamente o da zona Leste da cidade, é a possibilidade de utilizar-se da rede ferroviária, presente nesse setor urbano, quando a localização do conjunto habitacional assim o permitir, ou ainda acessar áreas geradoras de emprego também em municípios vizinhos.

Em relação ao novo centro de Iocalização empresarial, notadamente um polo gerador de empregos mais bem remunerados, que é o setor pericentral sudoeste, também se observou um 
Tabela 4. Unidades habitacionais produzidas no MCMV, por faixa de renda e por faixa de distância em relação ao centro urbano tradicional (adaptado de GI-SNH, 2018).

\begin{tabular}{ccccccc}
\hline Faixa / Distância & Até $\mathbf{5 ~} \mathbf{~ m}$ & $\mathbf{6}$ a $\mathbf{1 0} \mathbf{~ k m}$ & $\mathbf{1 1} \mathbf{~ 1 5} \mathbf{~ k m}$ & $\mathbf{1 6}$ a $\mathbf{2 0} \mathbf{~ k m}$ & $\mathbf{2 1} \mathbf{a} \mathbf{2 5} \mathbf{~ k m}$ & Total \\
\hline MCMV - faixa 1 & 0 & 140 & 592 & 3244 & 3502 & 7478 \\
MCMV - faixa 2 & 1469 & 1381 & 4582 & 4842 & 1938 & 12274 \\
MCMV - faixa 3 & 40 & 2483 & 4620 & 4588 & 2286 & 14017 \\
Total & 1509 & 4364 & 9794 & 12.674 & 7286 & 40308 \\
\hline
\end{tabular}

comportamento semelhante. Com pequenos percentuais de localização das UH na faixa até 10 $\mathrm{km}$, o pico das faixas 2 e 3 encontra-se no intervalo de 16 a 20 km de distância. Na faixa 1, no entanto, observa-se o pico, além de um crescimento forte, na faixa além dos $20 \mathrm{~km}$ de distância. Nessa avaliação, percebe-se que a distância média para as UH localizadas no setor leste e setor norte da cidade, aumentou, tornando essas localizações menos favoráveis. No caso do setor norte, ainda menos favorável por não poder contar com uma rede ferroviária ou metroviária que a interligue diretamente, à exceção de sua parte mais a oeste. No caso da faixa de renda 1, pela baixa escolaridade e capacitação técnica, esse centro não representa um setor de grande oferta de oportunidades de trabalho, sendo mais importante a oferta local de empregos (no próprio bairro ou setor urbano) e no centro tradicional, para o qual os sistemas de transporte coletivo convergem com mais facilidade.

Ressalta-se também que, com o deslocamento das atividades econômicas mais rentáveis para o setor sudoeste, devido à grande assimetria social urbana, as regiões Leste e Norte, exatamente as que mais produziram no Programa, ficaram mais

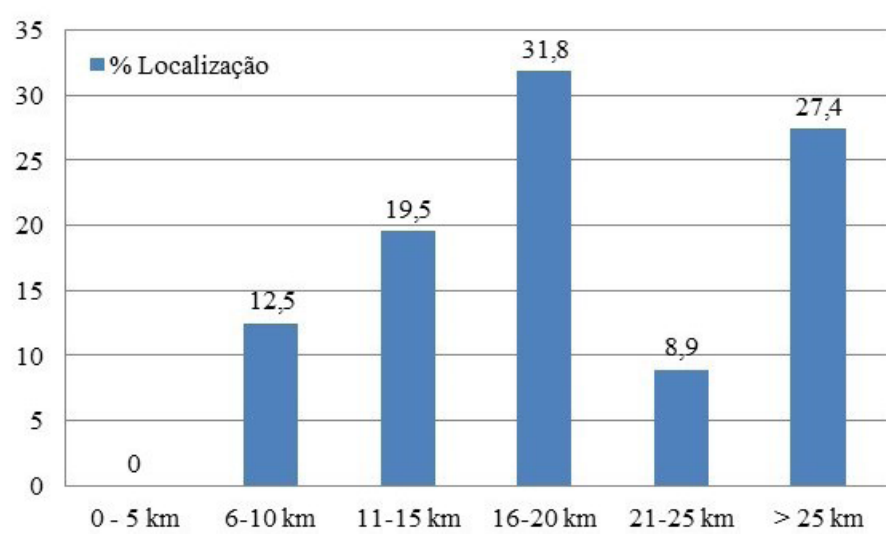

Fig. 2. Números percentuais da produção de UH-MCMV por faixa de distância entre os conjuntos habitacionais e o novo centro gerador de empregos em São Paulo/SP (adaptado de GI-SNH, 2018). distanciadas e prejudicadas, tanto do ponto de vista da distância, quanto do ponto de vista das alternativas e facilidades em transportes coletivos.

Em estudos como o de Linke et al. (2016), verificouse que, em princípio, nos conjuntos habitacionais implantados até $20 \mathrm{~km}$ de distância dos centros considerados, apesar da distância às melhores ofertas de trabalho, os conjuntos apresentam entornos urbanos relativamente consolidados, com relativa proximidade de oferta de bens e serviços públicos e privados, bem como sistemas de transportes coletivos de razoável qualidade. No entanto, a partir dessa distância, essas condições favoráveis diminuem bastante. Tal fato sinaliza uma precariedade maior para as habitações construídas nessas faixas, especialmente as localizadas nos setores Leste e Norte e que se tratam de conjuntos destinados a famílias de mais baixa renda (Faixa 1). Para esta faixa de renda, os subsídios são maiores, mas a liberdade de escolha de localização é menor.

\section{b. Relação entre a produção local de Unidades Habitacionais do MCMV e a oferta local (por bairro) de oportunidades de trabalho formal}

Esta relação se apresentou de maneira quase inversa, mas não linear, conforme mostra a figura 3. De forma clara, se observa que o percentual da produção de unidades habitacionais (eixo $\mathrm{x}$ ) foi bem mais intensa em setores de baixa oferta local de empregos formais (eixo y), o que reforça e corrobora que tal critério, em função do preço da terra, foi bastante utilizado para a escolha das áreas de implantação, com prejuízos claros para a população moradora.

No entanto, embora não se tenha os valores exatos das oportunidades de trabalho informal, percebese que em tais áreas, tais atividades são bem 


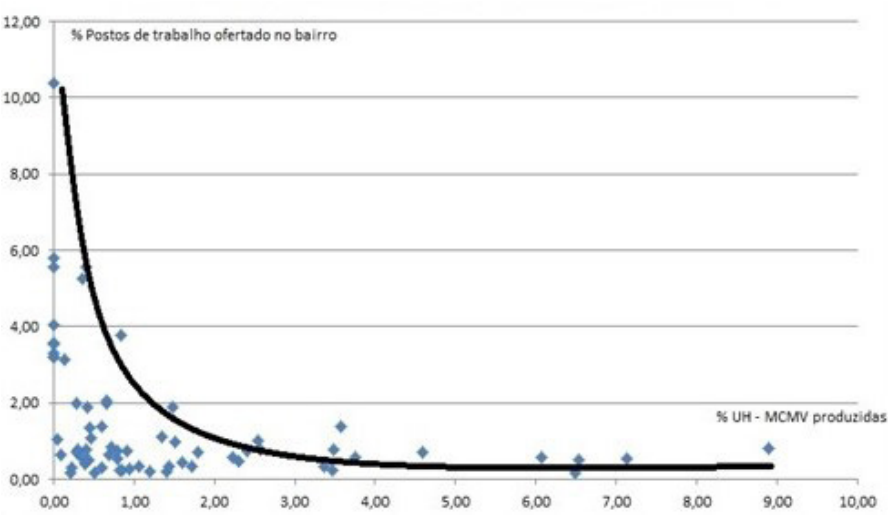

Fig. 3. Relação entre o percentual de UH produzidas por bairro e o percentual de postos de trabalho ofertados por distrito, no município de São Paulo/SP (adaptado de GI-SNH, 2018; PMSP, 2018).

presentes, com uma diversidade considerável de atividades, embora em grande parte, caracterizado pela precariedade das relações de trabalho e de certa fragilidade econômica que traduz também em certa fragilidade da qualidade de vida de seus moradores.

Outro fator que teve a capacidade de reduzir a precariedade dos bairros mais remotos onde foram implantados conjuntos habitacionais do Programa MCMV é a sua condição de proximidade com centros secundários no próprio município ou mesmo centros de outros municípios vizinhos.

\section{c. Relação existente entre o percentual de implantação de unidades habitacionais do MCMV e o índice local de violência urbana}

Para esse estudo, foi utilizado o índice clássico de violência urbana (taxa de homicídios/100 mil habitantes), adotado pela OMS e pelos Órgãos nacionais e internacionais de segurança pública. Os resultados demonstraram que, apesar da presença constante e numerosa de unidades habitacionais construídas em bairros considerados com altos índices de violência urbana, essa relação não se observou, apresentando dados bem dispersos, como pode ser observado na figura 4.

Apesar da alta concentração da violência em alguns bairros do setor sul e do setor norte, algumas áreas centrais e do setor oeste, com pouca construção habitacional no Programa apresentaram índices altos. O perfil característico da criminalidade na cidade (predominância de roubo de automóveis e assalto a bancos) faz apresentar altos índices também em áreas mais valiosas do ponto de vista imobiliário e, portanto, com pouca implantação de conjuntos MCMV. Ao mesmo tempo, o setor Leste, embora com o distanciamento da área central e dos setores geradores de emprego, se constitui um setor de grande quantidade de trabalhadores do comércio, serviços, construção civil e outras atividades de baixa remuneração, no entanto, são setores com poucas áreas de altos índices de criminalidade. Tais fatos explicam a dispersão verificada na figura abaixo.

Se, por um lado, observou-se grande produção habitacional em bairros que apresentam índices altos no contexto urbano, como Jardim Ângela (15,68 homicídios/100 mil habitantes - observado em 2011) que recebeu 606 unidades habitacionais e Campo Limpo (16,93 homicídios/100 mil habitantes) que recebeu 208 unidades, por outro lado, os bairros de Itaquera, São Miguel Paulista e Itaim Paulista, com índices de violência próximos da metade do bairro citado, receberam em média, mais que cinco vezes mais unidades habitacionais que os bairros mais violentos citados, ou seja: 3.124, 564 e 1.320 unidades habitacionais respectivamente.

Mas o caso mais emblemático dessa "não correspondência" entre índice de violência e construção de empreendimentos, notadamente no MCMV Faixa 1 foi o de Cidade Tiradentes, localizada a mais de $30 \mathrm{~km}$ do centro tradicional, com a mais

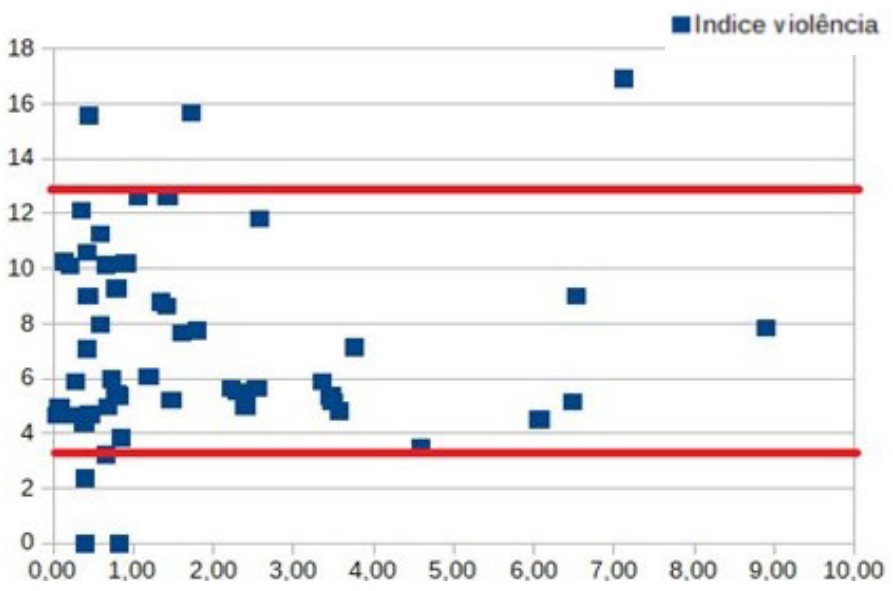

Fig. 4. (Não) relação entre o índice de violência (homicídios/100 mil habitantes) e o percentual de produção de unidades habitacionais no MCMV por distrito no Município de São Paulo (adaptado de GI-SNH, 2018; PMSP, 2018). 
alta concentração de empreendimentos apenas do MCMV faixa 1 (2.278 unidades habitacionais) e índice de violência menor do que a média do município: 5,17 homicídios/100 mil habitantes.

Dessa maneira, a conjectura da relação direta entre o índice de violência do bairro, fator que reduziria o valor da terra, e o percentual de produção de unidades habitacionais não se verificou. Notadamente no caso das faixas 2 e 3 , onde existe a possibilidade de escolha do local pelo futuro morador, esse fator seria considerado um fator de repulsão, reduzindo sensivelmente o valor da unidade habitacional, o que não agradaria os incorporadores dessas faixas. Apenas em casos onde, apesar dos altos índices de violência, o bairro estaria mais bem localizado em relação às oportunidades ou bairros considerados melhores, como o caso de Campo Limpo (16,93 homicídios/100 mil habitantes), foram observados índices mais elevados de implantação de unidades habitacionais de imóveis na faixa 2 e 3 . Sua proximidade em relação a bairros de mais alta renda (como o Morumbi) e áreas geradoras de emprego (Berrini) explica, em parte, esse comportamento excepcional. A figura 4 mostra essa dispersão e, ao mesmo tempo, uma predominância de localização das UH produzidas em áreas com índices médios de violência.

Apesar de que, na pesquisa sobre percepção social da violência elaborada pela Rede Nossa São Paulo/lbope inteligência (2019), a região Leste foi a que mais percebe um aumento da violência (81\% acham que a violência aumentou), os demais indicadores demonstram índices altos, como ocorre no país, mas moderados na comparação com outras cidades ou outras regiões da própria cidade. Na mesma pesquisa citada, observou-se que também o morador da zona Leste ainda é o que menos teme sair ou andar a pé durante a noite ou transportar dinheiro com medo da violência.

\section{d. A percepção da qualidade de vida pelos moradores nos diferentes setores da cidade}

Tomando-se como base os resultados da pesquisa Rede Nossa São Paulo-Ibope Inteligência (2019), que abrange moradores de todas as regiões da cidade verificou-se que os da região Norte foram os que mais atribuíram a nota máxima (satisfação total) à qualidade de vida na cidade (17\%), seguido dos setores Leste, Sul e Centro. Em relação à nota mínima (insatisfação total), observou-se que os menores índices de insatisfação ocorreram no Centro (1\%) e Região Leste (3\%). As maiores notas predominantes foram 8 (Região Norte e Oeste) e 7 (Região Sul e Leste).

Quando se avaliou os índices de satisfação por classe social (segundo a denominação econômica do IBGE), verificou-se que as classes $D$ e $E$ foram as que mais atribuíram a nota máxima de satisfação (23\%), embora também fossem as que mais atribuíram a nota mínima (17\%). Para essas classes de renda (que coincidem com as faixas do MCMV, notadamente a faixa 1), a nota predominante foi 8.

Para a classe de renda C o índice máximo de satisfação foi declarado por $13 \%$ e predominou a nota 07 e o índice para a insatisfação total foi de 3\%. Para as classes A e B o índice máximo foi declarado por $10 \%$ dos entrevistados e também predominou a nota 07 . Os que atribuíram a nota mínima foram 5\% dos entrevistados.

Embora a pesquisa adotada como referência para a percepção da qualidade de vida não tenha o recorte exato da população estudada, a adoção dos dois critérios simultaneamente (setor da cidade e faixa de renda) apresenta uma aproximação aceitável para a avaliação. Os resultados apresentados demonstram que, apesar da distância e da alta concentração de unidades de habitação de baixa renda, as regiões Leste, Norte e Sul mostraram índices de satisfação bastante próximos das demais regiões e até mais positivos nos setores de baixa renda, coincidentes com o perfil dos beneficiários do Programa MCMV.

\section{Considerações finais}

Ficou corroborada a prevalência do critério preço da terra e, portanto da preferência, por parte dos construtores (no caso da faixa 1 do MCMV) e dos incorporadores (no caso da faixa 2 e 3 do MCMV) da aquisição de terrenos em áreas mais distantes 
dos centros tradicionais e geradores de maior oferta de oportunidades de trabalho e renda bem como geradores de maior oferta de bens e serviços públicos e privados, em virtude do fator do custo da terra.

No entanto, verificou-se que, em função da própria dinâmica urbana, as faixas de distância onde se localiza a maior parte da implantação de unidades habitacionais do MCMV (10 a 20 km) (à exceção da faixa 1 que atinge distâncias ainda maiores em virtude da impossibilidade de escolha por parte do futuro morador), são atualmente áreas urbanas relativamente bem consolidadas, ofertando relativamente boa condição de acessibilidades a oportunidades, bens e serviços.

O maior problema ocorre nas áreas situadas a distâncias maiores que 20 km, onde predominam os empreendimentos da faixa de renda 1 , apresentando situações bastante diferentes entre si, variando em função da sua articulação com os centros secundários, a proximidade de centros de municípios vizinhos e da acessibilidade a rede de transporte coletivo, notadamente o transporte urbano ferroviário, capaz de atender grandes distâncias em um tempo de viagem mais aceitável. Além da maior disponibilidade de solo urbano plano e da alta concentração populacional, o que contribui para a diversidade de oferta de serviços e oportunidades, a melhor acessibilidade ao transporte público, notadamente o transporte ferroviário, foi um dos fatores que levaram o setor leste da cidade a ser o predominante na implantação de empreendimentos do MCMV.

Esse problema ainda se torna mais grave no caso do MCMV faixa 1, que conforme demonstrado, são mais frequentes ainda a distâncias superiores a 20 $\mathrm{km}$ das áreas de grande oferta de oportunidades e, por se localizarem mais frequentemente em áreas menos consolidadas, apresentam também menor oferta local de oportunidades, bens e serviços. Apenas em casos em que centros secundários ou centros de outros municípios vizinhos estejam próximos, devido à conurbação, tais áreas podem apresentar melhor condição habitacional.

No que diz respeito ao impacto de dispersão urbana e na contiguidade urbana no município de São Paulo, observou-se ainda que, apesar das distâncias em relação ao centro, a produção habitacional ocorreu dentro de áreas urbanas consolidadas, utilizando-se dos próprios vazios urbanos existentes. Além da própria condição de município central e, em grande parte, conturbado com outras áreas urbanas, outros fatores contribuíram para tal inserção: a) a utilização da verticalização e habitações multifamiliares em substituição às modalidades anteriores das casas unifamiliares; b) O próprio aperfeiçoamento gradativo dos normativos do MCMV ao longo do tempo, que veio exigindo inserção urbana, melhor condição infraestrutural e outras melhorias qualitativas. Dessa maneira, conclui-se que o impacto negativo sobre a estrutura urbana, no caso específico do município foi pouco clara, inclusive com alguns aspectos até positivos como o adensamento com a ocupação de lotes vazios. No entanto, como ocorreu em várias outras regiões metropolitanas, a dispersão do tecido urbano ocorreu especialmente pela transposição para os municípios periféricos, em um descolamento territorial indesejável da oferta em relação à real demanda habitacional.

Ficou evidente também a quase ausência de empreendimentos do Programa em áreas mais centrais (apenas 0,35\% das UH no centro tradicional e nenhuma UH do programa nos chamados centros novos), mesmo em uma cidade com alguma experiência anterior neste tipo de ação. Tal informação evidencia o equívoco de não se considerar outras modalidades, tais como a requalificação de edifícios deteriorados em áreas urbanas ou periurbana próxima. Tais soluções têm sido pouco consideradas pelas políticas estatais pelo seu alto investimento inicial. No entanto, têm sido relegadas as vantagens decorrentes dessa Iocalização para os moradores e para a cidade: a) aumento de oportunidades; b) ganho de tempo extra, anteriormente perdido em deslocamentos; c) redução dos fluxos de circulação motorizada intraurbanos; d) redução da deterioração de áreas centrais, e c) melhor qualidade de vida para o morador, com a grande oferta local de bens e serviços públicos e privados. 
Como alternativas menos onerosas que a construção para transferência da propriedade, outras modalidades poderiam ser buscadas, tais como a "Iocação social ou de aluguéis de valores moderados", inclusive com a participação privada, que poderia viabilizar soluções habitacionais para maior número de pessoas, com menores investimentos por parte do Estado. Tal solução vem sendo aplicada comumente e com muito êxito em vários países no mundo. Evidentemente, para que tais soluções venham a ser exitosas, seria imperioso adotar medidas de monitoramento e acompanhamento permanente (não congelamento, mas controle de inflexões especulativas) do valor dos aluguéis no sentido de se evitar que certa "cultura inflacionária" inviabilize um programa social de aluguéis de baixo custo em áreas centrais.

\section{Referências bibliográficas}

ANDRADE, L. S. Para além da unidade habitacional: pela moradia e pela cidade no contexto da construção da minha casa e da minha vida. Rio de Janeiro: Prourb-UFRJ / CNPa-SNH, 2015.

ATLAS MUNICIPAL. Trabalho e desenvolvimento. Cidade de São Paulo. 2017. Disponível em <atlasmunicipal.prefeitura.sp.gov.br/usuario/ Cadintermediario.aspx>. Acesso em 12 set 2019.

BAUMAN, Z. Confiança e medo na cidade. Rio de Janeiro: Jorge Zahar Ed, 2009.

BENITES SOBRINHA, M. D. P. Avaliação do Programa Minha Casa Minha Vida na Região Metropolitana de Natal - RN. Natal: UFRN/ CNPq-SNH, 2015.

BONDUKI, N. Os pioneiros da habitação social: cem anos de política pública de habitação no Brasil. São Paulo: Editora UNESP, 2014.

CAIXA Econômica Federal. Empreendimentos Minha Casa Minha Vida. Disponível em: <webp. caixa.gov.br/siurb/ao/pag/index.asp $>$. Acesso em 12 set 2019.

CARDOSO, A.L. et al. O Programa Minha Casa,
Minha Vida e seus efeitos territoriais. Rio de Janeiro: Letra Capital, 2013.

CARDOSO, A. L. Avaliação do Programa Minha Casa, Minha Vida na Região Metropolitana do Rio de Janeiro: impactos urbanos e sociais. Rio de Janeiro: IPPUR - UFRJ/ CNPq-SNH, 2015.

DUTRA, W. Z. Entre a produção habitacional estatal e as moradias precárias: uma análise da popularização da casa própria no Brasil. Revista Configurações - CICS, n. 10, ano 2012, pp. 151-164, 2012.

FERREIRA, J. S. W. Produzir casas ou construir cidades?. São Paulo: LabHab/FAUUSP, 2012.

LINKE, C. et al. Inserção urbana de habitação de interesse social: um olhar sobre a mobilidade cotidiana e o uso do solo. Brasília: IPEA - Textos para discussão, 2016.

NASCIMENTO, D. M. (org.) Programa Minha Casa, Minha Vida: Estudos avaliativos na RM de Belo Horizonte. Belo Horizonte: UFMG / CNPq - SNH, 2015.

PEQUeNO, L. R. B. Análise do Programa MCMV na Região Metropolitana de Fortaleza: Desenvolvimento institucional, inserção urbana e avaliação arquitetônica, construtiva e tecnológica. Fortaleza: UFC/ CNPq-SNH, 2015.

REDE NOSSA SÃO PAULO. Viver em São Paulo: Mobilidade. Relatório de pesquisa - Rede Nossa São Paulo/IBOPE inteligência, 2019.

REDE NOSSA SÃO PAULO. Viver em São Paulo: Segurança. Relatório de pesquisa - Rede Nossa São Paulo/IBOPE inteligência, 2019.

REDE NOSSA SÃO PAULO. Vive rem São Paulo: Qualidade de Vida. Relatório de pesquisa - Rede Nossa São Paulo/IBOPE inteligencia, 2019.

ROLNIK, R. Como produzir moradia bem localizada com recursos do programa Minha Casa, Minha 
Vida? - implementando os instrumentos do Estatuto da Cidade. Brasília: Ministério das Cidades, 2010.

SAULE JR., N. A produção do programa MCMV na Região metropolitana da Baixada Santista: impactos urbanos e ambientais dos empreendimentos. São Paulo: Instituto Polis, 2015.

SHIMBO, L. Z. Produção do PMCMV na região central do Estado de São Paulo: inserção urbana, projetos e impactos socio-econômicos. São Carlos: IAU-USP / CNPa - SNH, 2015.

SILVA, E. T. Estrutura urbana e mobilidade espacial nas metrópoles. Rio de Janeiro: Letra Capital, 2012. 
Publicação organizada pelo Programa de

Mestrado Profissional Stricto Sensu em

Engenharia Civil da Universidade São Judas

Volume 03 - Edição 01

Janeiro - Dezembro de 2020

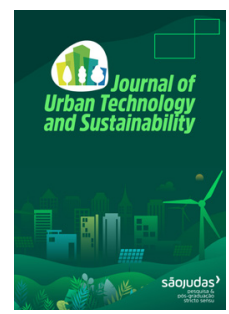

\section{Discurso sustentável e a prática de remanejamento: Estudo de caso em intervenção habitacional do Programa de Aceleração do Crescimento em Belém (PA)}

Marlon D. Castroa,

${ }^{a}$ Núcleo de Altos Estudos Amazônicos, Programa de Pós-Graduação em Desenvolvimento Sustentável do Trópico Úmido, Universidade Federal do Pará (NAEA/UFPA), Brasil.

\section{Informações}

Recebido 20 Outubro 2020

Manuscrito revisado recebido

27 Novembro 2020

Aceito 1 Dezembro 2020

\section{Palavras-chave}

Discurso sustentável

Programa de aceleração de crescimento

Projeto de trabalho técnico social

\section{Resumo}

Remanejamentos urbanos têm sido as práticas mais comuns para reduzir a quantidade de assentamentos precários vulneráveis do ponto de vista socioambiental na Região Metropolitana de Belém nas últimas décadas, mas seus resultados e efetividade ainda são discutíveis. Este artigo procura analisar as interpretações discursivas e aproximações ao conceito de sustentabilidade urbana em uma intervenção de habitação de interesse social oriunda do Programa de Aceleração do Crescimento (PAC) em Belém (PA), a partir do Projeto de Trabalho Técnico Social (PTTS), visando estabelecer nexos de sustentabilidade entre a população atendida pelo Programa durante a realização das obras da intervenção - o Projeto Taboquinha, localizado no distrito de Icoaraci. Foi utilizada pesquisa qualitativa a partir dos projetos técnicos, documentos, além de entrevistas semiestruturadas com técnicos elaboradores e executores. Percebe-se que em relação à sustentabilidade, tomando por base a categoria lazer, foco do estudo, o Projeto reproduz espaços sem relação com as vivências materiais e substantivas dos sujeitos atendidos, desconsiderando suas necessidades e práticas cotidianas.

\section{Sustainable discourse and the relocation practice: Case study in housing intervention of the Growth Acceleration Program in Belém (PA)}

\section{Article info \\ Received 20 October 2020 \\ Received in revised form 27 November 2020 \\ Accepted 1 December 2020}

\section{Keywords}

Sustainability

Growth acceleration

program

Technical social work

program

\begin{abstract}
Urban relocations have been the most common practices to reduce the number of socially and environmentally vulnerable precarious settlements in the Metropolitan Region of Belém in recent decades, but their results and effectiveness are still debatable. This article seeks to analyze the discursive interpretations and approaches to the concept of urban sustainability in a housing intervention of social interest originating from the Growth Acceleration Program (PAC) in Belém (PA), based on the Technical Social Work Project (PTTS), aiming to establish nexus of sustainability among the population served by the Program while carrying out the intervention works - the Taboquinha Project, located in the Icoaraci district. Qualitative research was used based on technical projects, documents, as well as semi-structured interviews with technical writers and executors. It can be seen that in relation to sustainability, based on the leisure category, the focus of the study, the Project reproduces spaces unrelated to the material and substantive experiences of the subjects served, disregarding their needs and daily practices.
\end{abstract}

\section{Discurso sostenible y práctica de relocalización: estudio de caso en intervención habitacional del Programa de Aceleración del Crecimiento en Belém (PA)}

\section{Información}

Recibido 20 Octubre 2020

Manuscrito revisado recibido 27 Voviembre 2020

Aceptado 1 Diciembre 2020

\section{Palabras clave}

Discurso sostenible

Programa de aceleración del crecimiento

Proyecto de trabajo técnico social

\section{Resumen}

Las reubicaciones urbanas han sido las prácticas más comunes para reducir el número de asentamientos precarios social y ambientalmente vulnerables en la Región Metropolitana de Belém en las últimas décadas, pero sus resultados y efectividad aún son discutibles. Este artículo busca analizar las interpretaciones y enfoques discursivos del concepto de sustentabilidad urbana en una intervención habitacional de interés social originada en el Programa de Aceleración del Crecimiento (PAC) en Belém (PA), con base en el Proyecto Técnico de Trabajo Social (PTTS), con el objetivo de establecer nexos de sustentabilidad entre la población atendida por el Programa durante la ejecución de las obras de intervención - Proyecto Taboquinha, ubicado en el distrito de Icoaraci. Se utilizó investigación cualitativa basada en proyectos técnicos, documentos, así como entrevistas semiestructuradas con redactores técnicos y ejecutores. Se puede observar que en relación a la sustentabilidad, a partir de la categoría de ocio, el foco del estudio, el Proyecto reproduce espacios ajenos a las vivencias materiales y sustantivas de los sujetos atendidos, desconociendo sus necesidades y prácticas diarias.

\footnotetext{
* Autor correspondente em: Núcleo de Altos Estudos Amazônicos, PPG em Desenvolvimento Sustentável do Trópico Úmido, UFPA.

E-mail: marloncastro@ufpa.br (Marlon. D. Castro)
} 


\section{Introdução}

A temática da sustentabilidade tem sido evocada, com frequência, de modo a fazer as expectativas de bem-estar transitarem dos âmbitos da habitação, da saúde e dos direitos sociais, fortemente marcados pelo acesso socialmente desigual, para uma noção de meio ambiente construída como una e comum a todos (ACSELRAD, 2005). Revestido, assim, dessa roupagem sustentável universalista, o meio ambiente convém aos propósitos de construção de um consenso social destinado a reconstituir, em um mundo socialmente fragmentado, o sentido de comunidade, solidariedade e interesse comum, buscando acomodar as diferenças em uma nova totalidade interdependente.

Acselrad (2009) pontua que a busca de um consenso urbano de tal forma ampliado espacial e temporalmente, legitimado nos propósitos do equilíbrio biosférico e da justiça intergeracional, explica-se pela necessidade de prevenção dos riscos de ruptura sociopolítica em cidades crescentemente fragmentadas pelos processos de globalização e acumulação flexível. Portanto, se o recurso à noção de sustentabilidade urbana parece integrar de forma crescente uma norma do planejamento aplicado a cidades fortemente divididas, o caráter simbólico das ações associadas a tal noção (seja pela representação retórica de um meio ambiente uno e consensual, seja pelo sentido que se queira imprimir às operações materiais "de conexão", empreendidas em seu nome) não parecerá suficiente para dar estabilidade aos mecanismos da reprodução urbana. A noção de sustentabilidade parecerá, assim, constituir apenas parte de um esforço mais amplo de configurar um novo modo de regulação urbana capaz de integrar duravelmente na dinâmica reprodutiva a própria desigualdade constitutiva das cidades.

É neste contexto que está inserido o Programa de Aceleração do Crescimento (PAC), programa estatal anticíclico que foi colocado em prática pelo governo brasileiro na segunda metade da década passada, com vistas a diminuir os efeitos da crise mundial surgida nos Estados Unidos, mas reverberada em escala planetária. O PAC consolidou-se como estratégia de ampla ação de movimentação econômica, principalmente ligada à construção civil nos grandes centros urbanos do país, estando dividido em eixos de atuação que vão desde o saneamento até a construção de unidades habitacionais. Com o PAC, dá-se continuidade à estratégia de substituição das áreas de baixadas belenense por conjuntos habitacionais, processo este que vem acontecendo nas últimas três décadas, ora ligado a remanejamentos, ora objetivando reassentamentos de famílias em outros espaços da malha urbana metropolitana.

Neste artigo, é analisado o discurso de sustentabilidade presente em um projeto de habitação de interesse social do PAC, referente ao eixo Urbanização de Assentamentos Precários, destinado ao remanejamento e ao reassentamento de famílias em situação de risco e vulnerabilidade socioambiental em Belém (PA).

A metodologia utilizada está centrada na análise qualitativa do Projeto de Trabalho Técnico Social (PTTS), referente às intervenções habitacionais do Projeto Taboquinha: conjuntos habitacionais Cruzeiro, Mestre Cardoso e Mestre Verequete, localizados no distrito de Icoaraci, em Belém, além de entrevistas semiestruturadas com técnicos responsáveis pela elaboração, execução e fiscalização das intervenções habitacionais, todas elas vinculadas à Companhia Executiva de Habitação do Pará (COHAB), além de entrevistas com chefes de família beneficiários do Programa. Este artigo está relacionado ao tema da tese de doutorado do autor, que analisa discursos de sustentabilidade presentes nas intervenções habitacionais de interesse social para remanejamento e reassentamento urbanos na Região Metropolitana de Belém, ora em desenvolvimento.

\section{Sustentabilidade e prática de remaneja- mento}

Entre vários termos derivados da ideia de desenvolvimento sustentável, um dos mais difundidos é o da sustentabilidade. O sentido semanticamente criado permite pensarmos na durabilidade e na continuidade de recursos e ações que impedem o esgotamento das condições de 
produção e reprodução social, criando um sentido de permanência em termos civilizatórios que os termos anteriormente consolidados sobre o tema não dispunham.

No entanto, ao apontar uma direção para a superação dos problemas ambientais, a sustentabilidade pode, ao contrário, estar mais do que apontando uma solução, mas induzindo à construção de um senso comum em torno dessa direção. Apontando uma saída, a ideia de sustentabilidade atua no sentido de criar uma falsa ideia de que este seria o único caminho possível para evitar um desastre ambiental planetário.

Acselrad (2009) diz que a associação da noção de sustentabilidade à ideia de que existe uma forma social durável de apropriação e o uso do meio ambiente dada pela própria natureza das formações biofísicas significa, por exemplo, ignorar a diversidade de formas sociais de duração dos elementos da base material do desenvolvimento. A construção de um caminho para a crise ambiental baseado na ideia de continuidade das coisas (recursos e atitudes) como elas são e sua apresentação como o único caminho a ser tomado devem ser entendidas como a construção de um conceito que busca preservar as estruturas produtivas, relações sociais, as estruturas políticas. Não se pode, portanto, aceitar a ideia de sustentabilidade como um remédio dado para os males ambientais em todos os níveis. É preciso reconhecer que existem várias maneiras de as coisas durarem, como lembra Acselrad.

O discurso da sustentabilidade foi a matriz conceitual por trás dos instrumentos legais criados no Brasil nos últimos anos para permitir uma apropriação privada cada vez maior dos recursos naturais, apresentando-se, por exemplo, na associação entre preservação ambiental e qualidade de vida, esta entendida como uma vida em harmonia com a natureza longe da poluição, o que deveria ser um valor universal, mas que, na prática, precisa ser adquirida como uma mercadoria, submetida como um valor de troca, pura e simplesmente. A sustentabilidade transformou a natureza numa commodity a ser explorada e dissolvida pelo capital. Neste sentido, a sustentabilidade revela seu lado mais perverso, uma vez que, num cenário de enormes desigualdades sociais, como o das grandes cidades brasileiras, só uma minoria das pessoas tem condições de experimentá-la, justamente pelo fato de que, no caso brasileiro, as discussões ambientais mundiais foram assimiladas sem que houvesse equacionamento das questões sociais (PRADO, 2015). Deste modo, para a maioria da população urbana do Brasil, para quem nenhum desenvolvimento concreto foi oferecido até hoje, a sustentabilidade parece um sonho muito distante.

A ideia de "desenvolvimento urbano sustentável" pode ser considerada de antemão uma contradição em termos, como aponta Costa (2006). Isso porque a expressão tenta conciliar o que é aparentemente inconciliável, o crescimento da cidade e sua qualificação ambiental. Essa ideia surgiu entre o final dos anos de 1980 e início dos anos de 1990, no contexto geral de consolidação do conceito geral de desenvolvimento sustentável, em um momento em que dois campos distintos tentam fazer convergir seu pensamento, apesar de suas origens e objetivos completamente diferentes: o campo da análise ambiental e o campo da análise urbana. Essa aproximação foi amadurecida ao longo de muitos anos durante os quais os estudos ambientais dentro das competências do planejamento urbano permaneceram restritos a nichos técnicos, enquanto estudos urbanos dentro do campo das ciências ambientais praticamente inexistiam (COSTA, 1999).

Questões ambientais urbanas, como o saneamento das cidades, foram durante muito tempo tratadas relativamente à eficiência, com base muito mais numa racionalidade técnico-científica do que em termos ambientais, numa perspectiva mais ampla e sistêmica. A visão integrada entre as diversas questões ambientais urbanas ainda é pouco comum no universo do planejamento urbano estatal brasileiro, por isso, em limites institucionais, o conceito de "desenvolvimento urbano sustentável" sempre esbarrou na divisão política e administrativa em que são acomodadas as principais questões ambientais e urbanas.

Nas últimas décadas, entretanto, o conceito de sustentabilidade vem sendo atrelado a uma 
forma hegemônica de pensar a sociedade e a natureza, ignorando as determinações históricas do processo produtivo capitalista, essencialmente destrutivo, permanecendo radicado muito mais como uma ideologia que unifica os interesses dos trabalhadores, dos empresários e do Estado em torno da defesa de uma pretensa sustentabilidade ambiental, social e econômica (PRADO, 2015).

Costa (1999) destaca quetratardesustentabilidade urbana, ou mesmo buscar definições sobre o que representa o conceito de sustentabilidade, apresenta-se como uma tarefa complexa e, por vezes, contraditória. Essa dificuldade se deve, em parte, à banalização do termo em razão de seu emprego contínuo como viés publicitário por grandes empresas multinacionais ou, então, por agências internacionais que o incluem no bojo de interesses particulares e que pouco tem a ver com a conciliação entre preservação do meio ambiente e objetivos de desenvolvimento.

Percebe-se que outro segmento tem se concentrado em usar o termo com foco unicamente na sua dimensão ecológica, sem se preocupar em contemplar as necessidades humanas. Por outro lado, a aplicação do conceito à dimensão urbana traz consigo conflitos teóricos de difícil conciliação. Esses conflitos tendem a se concentrar em duas direções: uma que envolve a trajetória da análise ambiental e da análise urbana, as quais se originaram de áreas do conhecimento diferentes, mas convergem na proposta de um desenvolvimento urbano sustentável; e outra mais restrita à dimensão prática, em que se verifica um distanciamento entre formulações teóricas e propostas de intervenção (COSTA, 1999).

Em relação às políticas habitacionais, percebe-se que o elemento sustentabilidade é muito propalado, inclusive existindo certificações nacionais e internacionais para sua mensuração no ambiente construído, especificamente criadas para avaliar a sustentabilidade em projetos, desde a elaboração do projeto técnico até o pós-ocupação, o que, no entanto, não garante a consolidação da conexão entre a intervenção, as necessidades da população atendida e a cidade (CEF, 2010).

A inserção qualitativa dos projetos e famílias na malha urbana é problemática, principalmente por alterações no modo de vida. Relações com o espaço e com o mundo do trabalho também necessitam atenção, pois vão de encontro a qualquer interpretação do conceito de sustentabilidade urbana. Especificamente no que tange à RMB, existem importantes lacunas a serem preenchidas sobre a discussão entre política habitacional concebida nas últimas décadas para remanejamento e reassentamento, essencialmente visando à superação dos problemas de saneamento das "baixadas" (CASTRO, 2013; LEÃO; LIMA, 2017).

Diante da ambiguidade da atuação do setor público no que se refere à implementação de políticas urbanas comprometidas com a sustentabilidade, há, em Belém e região, uma forte concorrência das estratégias de uso e ocupação do solo impostas pelo capital imobiliário. Ao mesmo tempo, a RMB é apresentada como a região metropolitana brasileira com maior extensão de assentamentos precários (IBGE, 2010), que, em grande medida, correspondem às áreas "de baixada"1 que foram ocupadas informalmente e guardam uma articulação de origem com a tradição ribeirinha (CARDOSO; VENTURA, 2013).

Ainda que o espaço produzido informalmente tenha limitações e precariedades (ruas estreitas, carência de infraestrutura, adensamento excessivo), ele garante aos seus moradores efetiva mobilidade por meio de transporte público e bicicleta, ou mesmo a pé. Apresenta, ainda, diversidade de usos, boa conexão com a cidade formal e oportunidades de geração de renda, todos estes, aspectos positivos quando se consideram o espraiamento e o consumo energético como fatores de insustentabilidade. O fato de não ter havido planejamento prévio foi compensado pela natureza gradual da ocupação e das melhorias realizadas, o que permitiu que sua população original pudesse permanecer na área (CARDOSO; VENTURA, 2013).

Historicamente, a ausência de alternativas

1 As baixadas belenenses seriam uma forma de assentamento informal própria da cidade amazônica, na qual o pobre urbano utiliza estratégias de sobrevivência na cidade ligadas as suas referências regionais. É relevante nas baixadas a presença de aspectos culturais tanto na ocupação física como na dinâmica econômica e forma como as redes sociais são estabelecidas (LEÃO, 2017). 
habitacionais para a maior parte da população de baixa renda das grandes e médias cidades brasileiras condicionou que essa população se instalasse em espaços irregulares, do ponto de vista jurídico, e precários, do ponto de vista ambiental: ocupações informais, loteamentos irregulares, áreas alagadiças e/ou inundáveis, íngremes etc., áreas geralmente protegidas por lei e desprezadas pelo mercado imobiliário, o que tornou grande parte da população destas cidades passível a risco ambiental e social (ACSELRAD, 2009).

Há urgência na superação do contexto de exclusão e risco dessa população historicamente apartada da cidade e de seus benefícios. Medidas que regularizem estes assentamentos informais, possibilitando a inserção de equipamentos urbanos, infraestrutura e serviços visando a reduzir a vulnerabilidade social e ambiental de comunidades e populações devem ser vistas como prioritárias (MARICATO, 2005; UN-HABITAT, 2009). Em algumas áreas, entretanto, onde há a impossibilidade de realização de melhorias devido ao fato de oferecerem risco à saúde e à vida, segundo a recomendação técnica e legal, são necessárias ações de reassentamento.

O Ministério das Cidades (MCIDADES) denomina reassentamento como alteração do local de moradia de famílias, implicando sua remoção para outro terreno, fora do perímetro do assentamento precário que está sendo urbanizado.

"Reassentamento trata-se da produção de novas moradias de diferentes tipos (apartamentos, habitações evolutivas, lotes urbanizados) destinadas aos moradores removidos de assentamentos precários não consolidáveis ou que habitam assentamentos consolidáveis com remoção" (MCIDADES, 2010, p. 26).

O reassentamento é a medida mais drástica a ser tomada em situações de populações em risco, ocorrendo excepcionalmente quando o assentamento não é consolidável, por encontrarse em áreas de risco, seja de inundações urbanas, desmoronamento ou outras (ABIKO; COELHO,
2009; MCIDADES, 2010; ROLNIK et al. 2011).

O remanejamento, por sua vez, para o Ministério das Cidades (2010), trata-se da

\begin{abstract}
“...] manutenção da população (ou de grande parcela desta) no local da intervenção. É o caso, por exemplo, de áreas que necessitam de troca de solo ou aterro, nas quais a solução é a remoção temporária das familias, a execução de obras de infraestrutura e construção de novas moradias neste mesmo terreno. A intervenção, neste caso, também envolve a abertura de sistema viário, implantação de infraestrutura completa, parcelamento do solo, construção de equipamentos (quando necessária) e a regularização fundiária" (MCIDADES, 2010, p. 24-25).
\end{abstract}

Assim, as terminologias "remanejamento" e "reassentamento", são utilizadas para definir o processo de deslocamento de populações. O curso Ações Integradas de Urbanização de Assentamentos Precários (MCIDADES, 2010) destacou que esses termos ainda podem ser equiparados aos de relocação e realocação.

Os reassentamentos e remanejamentos não podem ser arbitrários, seguindo interesses de mercado. Devem, sim, ser baseados no direito à cidade e no direito à moradia, utilizados sempre como última opção, quando nenhuma intervenção de infraestrutura, como macrodrenagem ou obras de contenção, por exemplo, for capaz de reduzir os riscos a que a população esteja sujeita (UN-HABITAT, 2012). Para Maricato (2003), o grande desafio das políticas urbanas e ambientais brasileiras no século XXI é justamente aliar a democratização da produção de novas moradias ao acesso à moradia legal e à cidade com todos os seus serviços e com infraestrutura e, nesse ponto, o acesso ao solo urbano constitui aspecto fundamental para uma cidade mais justa.

Reassentamentos e remanejamentos, pela sua efetivação, dizem estar conectados a algum sentido de sustentabilidade urbana e condizerem com a superação de um quadro de vulnerabilidade socioambiental que não é privilégio apenas do Brasil e da RMB. 
Cotidianamente, a população de mais baixa renda habitante das grandes cidades da América Latina, não coincidentemente a de maior vulnerabilidade social e ambiental, também está sujeita aos riscos de inundações, escorregamentos de encostas, convivência com resíduos perigosos, entre outras situações. Jacobi (2004) ressalta que não se pode negar a estreita relação entre riscos urbanos e o uso e ocupação do solo na cidade, pois nesta "é onde se delineiam os problemas ambientais de maior dificuldade de enfrentamento".

A localização das habitações dentro das cidades relaciona-se diretamente ao acesso ao solo urbano, de modo que as residências ocupantes de áreas menos privilegiadas, do ponto de vista físico, podem ser expostas a maiores ou menores riscos ambientais, sociais, de saúde, entre outros. Dessa maneira, os riscos estão intimamente ligados à espacialidade urbana que, em casos como o de Belém, denotam vulnerabilidade socioambiental e histórico de segregação socioespacial. A atuação governamental sobre o solo urbano é de fundamental importância para a compreensão dos limites e das possibilidades das estratégias ditas sustentáveis em uma metrópole que possui características muito peculiares de formação socioespacial e tratamento da precariedade ambiental ainda descolada dos aspectos sociais, tal como a habitação.

\section{O Programa de Aceleração do Crescimen- to (PAC)}

Objeto empírico deste estudo, o Programa de Aceleração do Crescimento (PAC), foi criado em 2007 com o objetivo de retomar o planejamento e a execução de grandes obras de infraestrutura social, urbana, logística e energética do país, "contribuindo para o seu desenvolvimento acelerado e sustentável" (MCIDADES, 2017). Foi pensado como uma estratégia para resgate do planejamento e retomada dos investimentos em setores estruturantes do país, a fim de contribuir para o aumento da oferta de empregos e a geração de renda, principalmente no setor da construção civil, elevando o investimento público e privado em obras consideradas estratégicas.
Na área de habitação, os investimentos do PAC têm como objetivo promover o acesso à moradia a partir da atuação em três eixos: Programa Minha Casa Minha Vida, Urbanização de Assentamentos Precários (UAP) e financiamento habitacional pelo Sistema Brasileiro de Poupança e Empréstimo (SBPE). São investimentos realizados em parceria com governos estaduais, municipais, entidades urbanas e rurais e setor privado (MPOG, 2016).

Estudar o PAC como política habitacional que teoricamente visa à superação da informalidade e, principalmente, da vulnerabilidade socioambiental com a diminuição de áreas de risco nas grandes cidades não tem relação apenas com a interpretação das noções de sustentabilidade, mas, antes, com a superação da desigualdade social. A transição vivida pelas famílias atendidas pelo PAC entre dois universos distintos é complexa e permeada por alterações nas relações desses sujeitos com o espaço produzido, com o lugar e com a cidade. Estas alterações não ocorrem apenas na dimensão simbólica, mas principalmente na materialidade das relações com o entorno das intervenções, com o trabalho, a mobilidade urbana, entre outras práticas sociais importantes para sua reprodução.

O PAC foi anunciado como um pacote de expansão da economia brasileira, com a retomada de investimentos em moradia e infraestrutura social, por meio de grande número de projetos visando à melhoria de espaços metropolitanos geridos pelo Governo Federal em parceria com estados e municípios. Destacam-se, entre suas diretrizes gerais, a priorização de investimentos em áreas de risco, de insalubridade e degradação ambiental, cuja demanda se sobreporia, em tese, à localização de áreas de precariedade infraestrutural e pobreza urbana (LEITÃO, 2009; LIMA et al., 2007).

O Programa é composto por um conjunto de medidas de médio e longo prazo, que integra ações em três "eixos estratégicos": infraestrutura social e urbana, infraestrutura logística e infraestrutura energética (BRASIL, 2010). Parte expressiva dos recursos destinados à chamada "infraestrutura social e urbana" foi direcionada para a recuperação de áreas ambientalmente degradadas e, mais especificamente, para ações relativas à urbanização 
de assentamentos precários, outrora viabilizados através de programas como o Crédito Solidário e o Pró-Moradia, bem como por linhas de financiamento como o Projeto Prioritário de Investimento (PPI) para intervenções em favelas, carro-chefe do PAC desde o seu início (CARDOSO, 2009).

Segundo dados do Ministério do Planejamento Orçamento e Gestão (MPOG) de 2016, os projetos PAC-UAP, na RMB, estavam majoritariamente localizados em Belém: 15 projetos iniciados, dos quais 10 contratados pelo Governo do Estado do Pará e 5 pela Prefeitura Municipal de Belém (PMB). Deste total, havia, em dezembro de 2017, 6 projetos atrasados, 5 paralisados, 4 contratados (mas não iniciados) e, ainda, nenhum finalizado. 0 total previsto é de 7.476 unidades. O município de Ananindeua possui 3 projetos do PAC-UAP iniciados, todos contratados pela Prefeitura, prevendo-se a construção de 730 unidades, porém os projetos estavam paralisados (MPOG, 2016). A Tabela 1 lista as obras em Urbanização de Assentamentos Precários nos municípios de Ananindeua e Belém.

Desde 2007, foram realizados, pelo Governo do Estado do Pará e pelas prefeituras de algumas cidades abrangidas pelo PAC, na modalidade UAP, investimentos públicos que contemplam prioritariamente famílias de baixa renda com implementação de infraestrutura urbana e produção de unidades habitacionais (UH). A Figura 1 destaca as intervenções do PAC-UAP na RMB até o ano de 2016.

Os projetos PAC-UAP resultam, também, da existência prévia de projetos iniciados em outras linhas de financiamento, como o Pró-Moradia, que por ele foram incorporados. Assim, segundo estudo do IPEA/IDESP (2013), a decisão pelas áreas não foi resultado de "definições baseadas em planos setoriais, senão por diferentes conjunturas como a existência de outras intervenções já iniciadas ou a mobilização da população e articulação com representações de movimentos de moradia".

Tais projetos, ainda que apresentem grande dificuldade em sua implementação, representam a possibilidade de integração urbana e social de assentamentos precários, em sua maioria inseridos na malha urbana dos municípios e em localizações qualitativamente diferentes na perspectiva da reprodução social. Efetivamente, o número de unidades habitacionais previstas também é relevante, frente à quantidade de unidades que governo estadual e prefeituras foram capazes de produzir nas últimas décadas, com o bônus de aceleração de processos de consolidação das comunidades e maior acesso da população a serviços urbanos (LIMA; LEÃO, 2017).

Desse modo, compreende-se que o trajeto percorrido pelas famílias contempladas pelos projetos de reassentamento ou remanejamento (e, com ele, mudança de habitação, espaço físico, condições de vida e residência, relações com o espaço) é importante para a análise da sustentabilidade urbana, pois, em tese, esse trajeto refletiria um esforço institucional para superação das vulnerabilidades ambiental e social - históricas, no caso da RMB. No caso das intervenções do PACUAP, essa análise está intimamente relacionada à necessidade de contenção dos efeitos da Crise Mundial em escala nacional, subvertendo a lógica criada, de forma participativa até então, para a política habitacional de interesse social, tornandose uma política estratégica com primazia mais pela objetividade, e menos pela consideração à totalidade urbana.

\section{Materiais e métodos}

A pesquisa realizada teve como lócus, as intervenções realizadas e especificamente destinadas ao remanejamento de famílias em situação de vulnerabilidade socioambiental do Projeto Taboquinha, em Belém (PA). Essas intervenções são subprojetos que visam à provisão habitacional e que fazem parte de projetos do PAC contemplados no eixo da Infraestrutura Social e Urbana.

Optou-se por essas intervenções pelo fato de possuírem beneficiários reassentados de áreas precárias do ponto de vista ambiental e social da RMB; e pelo fato de as unidades terem sido entregues há mais de dois anos, o que caracteriza a consolidação das famílias nos espaços a seguir elencados: 
Tabela 1. Projetos PAC-UAP na RMB (Adaptado de MPOG, 2016).

\begin{tabular}{|c|c|c|c|c|c|}
\hline $\begin{array}{l}\text { Município } \\
\text { beneficiado }\end{array}$ & Proponente & Empreendimento & $\begin{array}{l}\text { Data de } \\
\text { seleção }\end{array}$ & $\begin{array}{l}\text { Investimento total } \\
\text { (em R\$ milhares)* }\end{array}$ & Estágio \\
\hline Ananindeua & Município & Urbanização Icuí & Dez/07 & 44.628.891,89 & Em obras \\
\hline Ananindeua & Município & $\begin{array}{l}\text { Urbanização - Nova Esperança e } \\
28 \text { de agosto }\end{array}$ & Dez/07 & $20.377,66$ & Em obras \\
\hline Ananindeua & Município & Urbanização Distrito Industrial & Dez/07 & $18.106,21$ & Em obras \\
\hline Belém & Estado & $\begin{array}{c}\text { Riacho Doce e Pantanal ( } 3^{a} \\
\text { etapa) }\end{array}$ & Ago/07 & $24.470,46$ & Em obras \\
\hline Belém & Estado & $\begin{array}{l}\text { Comunidade Pantanal } \\
\text { (Mangueirão) }\end{array}$ & Ago/07 & $27.134,94$ & Em obras \\
\hline Belém & Estado & $\begin{array}{l}\text { Urbanização Riacho Doce e } \\
\text { Pantanal ( } 2^{a} \text { Etapa) }\end{array}$ & Ago/07 & $19.745,50$ & Em obras \\
\hline Belém & Estado & $\begin{array}{l}\text { Urbanização Riacho Doce e } \\
\text { Pantanal (1ª Etapa) }\end{array}$ & Ago/07 & $12.859,94$ & Em obras \\
\hline Belém & Estado & $\begin{array}{l}\text { Urbanização - Igarapé } \\
\text { Taboquinha** }\end{array}$ & Ago/07 & $77.876,01$ & Em obras \\
\hline Belém & Estado & $\begin{array}{c}\text { Urbanização - Comunidade Fé em } \\
\text { Deus }\end{array}$ & Ago/07 & $22.723,45$ & Em obras \\
\hline Belém & Estado & $\begin{array}{l}\text { Urbanização - Comunidade } \\
\text { Pratinha (Distrito de Icoaraci)** }\end{array}$ & Ago/07 & $30.679,71$ & Em obras \\
\hline Belém & Estado & Urbanização - Liberdade & Nov/09 & $19.999,61$ & Em obras \\
\hline Belém & Estado & $\begin{array}{c}\text { Urbanização - Residencial } \\
\text { Liberdade I }\end{array}$ & Jan/08 & $21.859,62$ & Em obras \\
\hline Belém & Estado & $\begin{array}{c}\text { Provisão Habitacional - Sede do } \\
\text { município }\end{array}$ & Mai/08 & $135.754,51$ & Em obras \\
\hline Belém & Município & Urbanização - Portal da Amazônia & Ago/07 & $25.930,21$ & Em obras \\
\hline Belém & Município & $\begin{array}{c}\text { Urbanização - Vila da Barca - } \\
\text { Artur Bernardes }\end{array}$ & Nov/10 & $15.755,80$ & Em obras \\
\hline Belém & Município & $\begin{array}{l}\text { Urbanização - Estrada Nova - } \\
\text { Sub-bacia - bairros Jurunas, } \\
\text { Cidade Velha e Batista Campos }\end{array}$ & Dez/07 & $66.417,34$ & Em obras \\
\hline Belém & Município & $\begin{array}{c}\text { Urbanização - Vila da Barca - } 3^{a} \\
\text { etapa }\end{array}$ & Ago/07 & $68.957,38$ & Em obras \\
\hline Belém & Município & $\begin{array}{c}\text { Município Urbanização - Bacia do } \\
\text { Paracuri }\end{array}$ & Dez/07 & $68.763,36$ & Em obras \\
\hline Castanhal & Estado & $\begin{array}{c}\text { Urbanização - Comunidade } \\
\text { Providentinos }\end{array}$ & Out/07 & $7.694 .558,33$ & Concluído \\
\hline Marituba & Município & $\begin{array}{c}\text { Provisão habitacional - Bairro } \\
\text { Decouville }\end{array}$ & Mai/09 & $2.441 .700,00$ & Em obras \\
\hline $\begin{array}{l}\text { Santa Isabel do } \\
\text { Pará }\end{array}$ & Estado & $\begin{array}{c}\text { Urbanização - Residencial Jardim } \\
\text { das Garças }\end{array}$ & Ago/07 & $7.719 .202,04$ & Em obras \\
\hline
\end{tabular}

* Inclui investimento de 2007 a 2014.

** Não inclui o valor da provisão habitacional conjugada, que foi considerado em item específico.

Projeto Taboquinha (composto por três conjuntos habitacionais: Conjunto Mestre Verequete, Conjunto Mestre Cardoso e Conjunto Cruzeiro), Iocalizado no bairro Cruzeiro, Distrito de Icoaraci, em Belém (figura 2). Nestes conjuntos foram reassentadas, em blocos verticais, 978 famílias que ocupavam as margens do Igarapé Cubatão, também em Icoaraci. Esses subprojetos de conjuntos habitacionais estão relacionados ao Projeto de Urbanização da Bacia do Paracuri, que contempla, além da construção de unidades habitacionais, a urbanização de toda a área externa ao residencial e prevê, ainda, a recuperação do Igarapé Cubatão.

Dentre todos os projetos PAC-UAP em execução ou contratados na RMB, os aqui elencados para comporem o objeto empírico desta pesquisa 


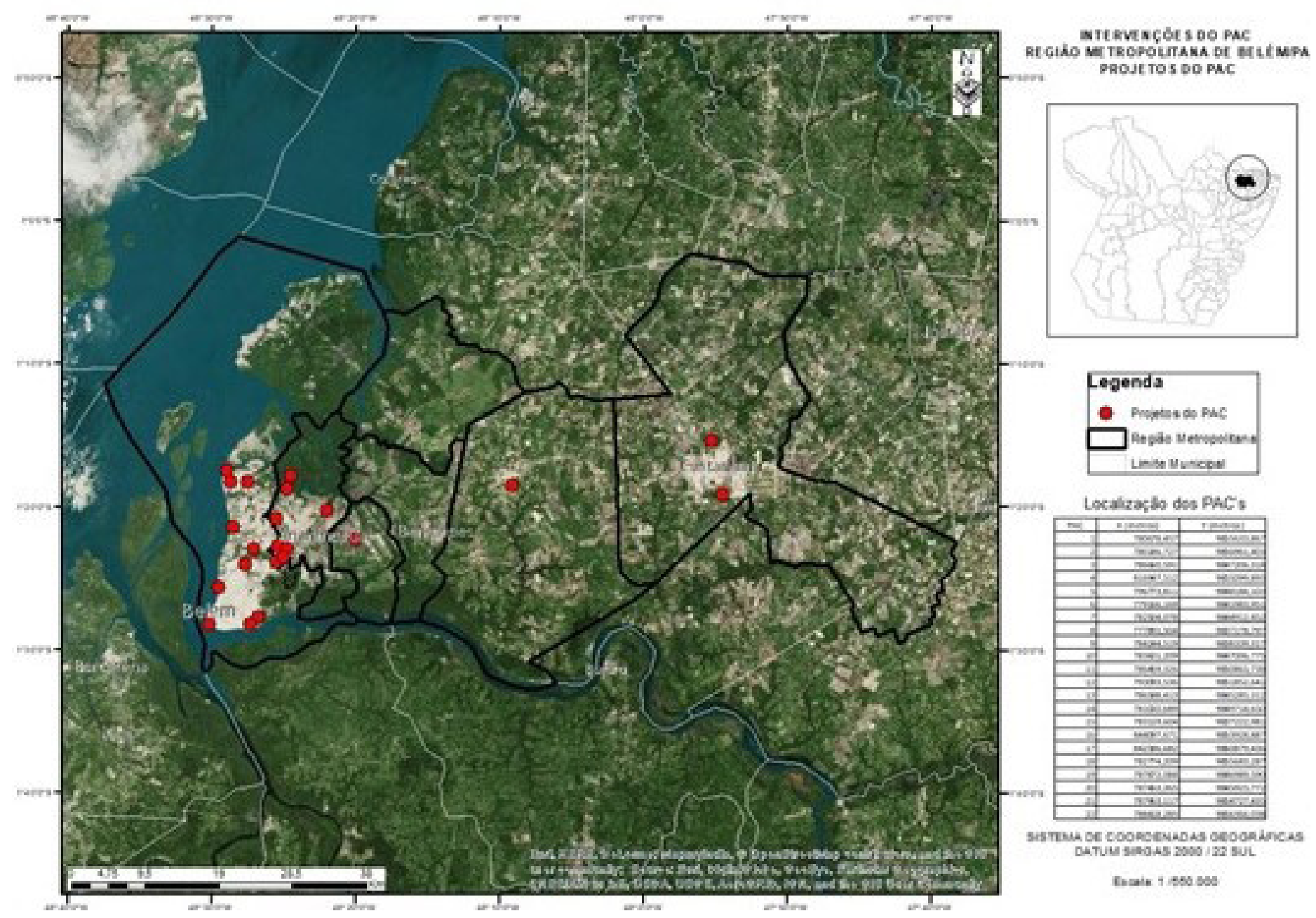

Fig. 1. Projetos PAC-UAP na RMB (adaptado de IBGE, 2012; MPOG, 2016).

correspondem a ações reassentamento e remanejamento, em que a transição entre espaços de habitação já ocorreu pelo menos em parte e em obediência aos critérios anteriormente destacados.

A abordagem metodológica deste estudo teve como preocupação captar e compreender os sujeitos sociais, em suas ações e relações, como produtores de sua existência material e social, por meio da utilização de abordagem qualitativa interdisciplinar ${ }^{2}$ sobre o Projeto de Trabalho Técnico Social (PTTS) de intervenções habitacionais pensadas para remanejamento e reassentamento de famílias de áreas de risco ambiental no Igarapé Cubatão, no distrito de Icoaraci, em Belém. Dessa

2 Para Japiassu (1976), o trabalho interdisciplinar propriamente dito supõe uma interação das disciplinas, uma interpenetração ou interfecundação, indo desde a simples comunicação das ideias até a integração mútua dos conceitos (contatos interdisciplinares), da epistemologia e da metodologia, dos procedimentos, dos dados e da organização da pesquisa. Para o autor, é imprescindível a complementação dos métodos, dos conceitos, das estruturas e dos axiomas sobre os quais se fundam as diversas disciplinas. O objetivo utópico do interdisciplinar é a unidade do saber. postura e concepção, derivaram os procedimentos metodológicos, técnicos e estratégicos utilizados nesta investigação.

Inicialmente foi solicitado o documento original do PTTS junto à Companhia Executiva de Habitação do Pará (COHAB), além de relatórios pós-ocupação das intervenções. Paralelamente, foram realizadas entrevistas semiestruturadas com técnicos diretamente envolvidos no planejamento, execução e avaliação dos PTTS e dos projetos físicos intervenções estudadas, além de entrevistas com beneficiários das ações, moradores dos conjuntos habitacionais que participaram desde o início na transição entre os espaços de ocupação irregular e vulnerável até o seu ingresso e consolidação nestas intervenções. Os entrevistados são identificados pelas letras "T", para técnicos, e "B", para beneficiários na análise dos dados.

Lefebvre (1977) identifica três dimensões da cotidianidade que, postas em relação dialética, 


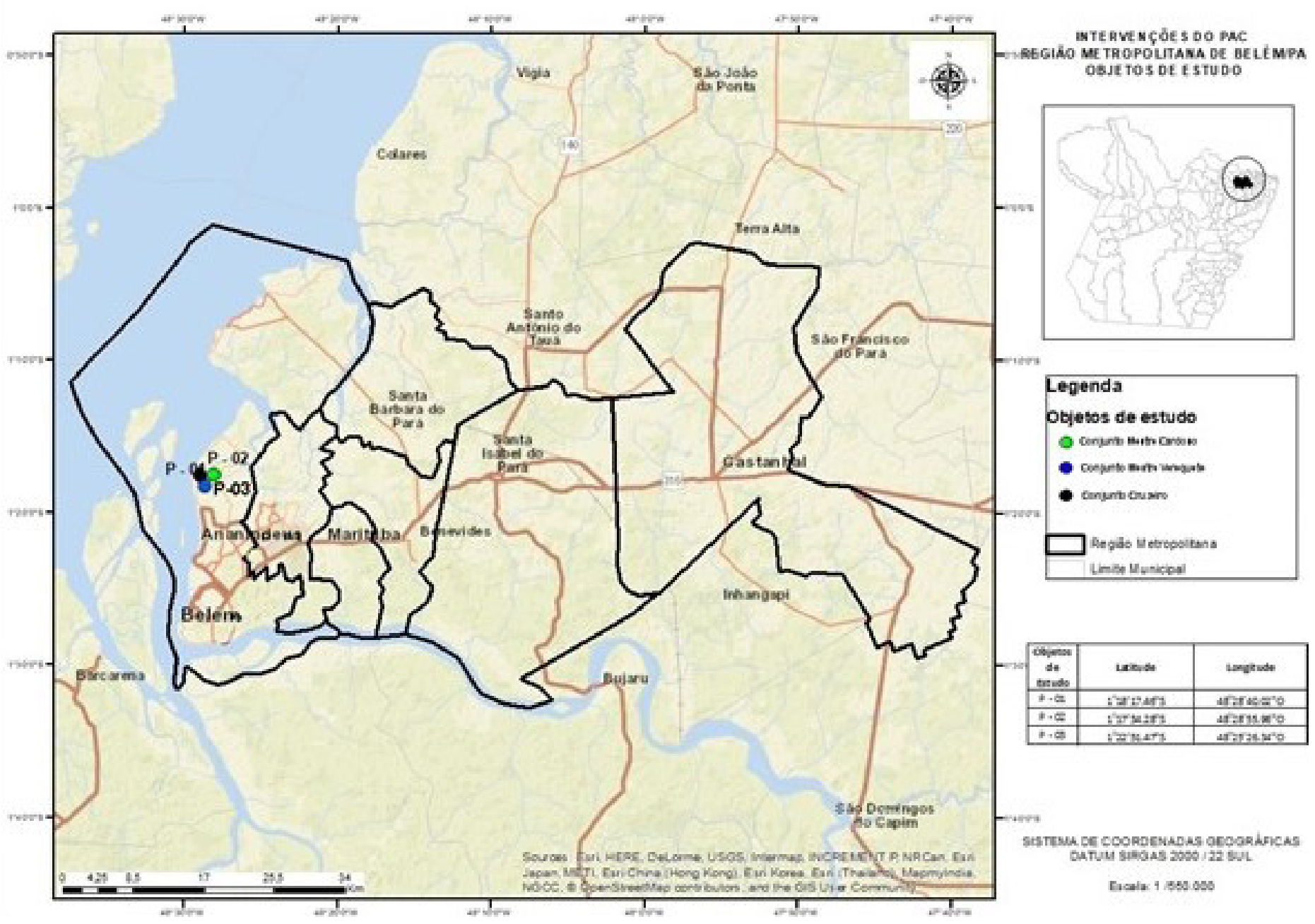

Fig. 2. Conjuntos Habitacionais do PAC-UAP objetos de estudo (adaptado de IBGE, 2010; IPEA/IDESP, 2014).

constituem uma unidade, portanto uma totalidade que deve ser apreendida. Essas três dimensões são o trabalho, a família e o lazer. Assim, o projeto lefebvriano supõe um estudo das possibilidades e limitações contidas nessas duas dimensões da existência social humana, a dimensão material e a dimensão social.

Nesse sentido, pensar o cotidiano na sua tripla dimensão (trabalho, família e lazer) é pensá-lo como uma esfera tensa da vida social carregada de conflitos. Esses três termos definem uma relação dialética em que as normas e os padrões de interação se contradizem ou se negam, eles também marcam, na sua estrutura, as possibilidades de existência concreta dos seres humanos. A ideia de que toda realização humana e de que toda integração social se dá pelo trabalho é contraposta à situação concreta dentro do modo de vida do moderno em que os projetos de vida, as aspirações, os desejos e sonhos de cada indivíduo envolvem essas três dimensões, isto é, o social como pressuposto da existência humana também se concretiza no lazer e na vida privada (familiar).

O uso da tríade dialética é essencial em nossa análise, pois, tal como Lefebvre (1977) acredita que o presente não esclarece o real, necessitando-se de regressão em busca de encontrar o marco da mudança, nosso percurso metodológico requer um esforço de reflexão cujo pano de fundo é o método dialético de investigação, pois nos faz enxergar que, por trás de toda a coerência que o modo de produção capitalista tenta passar, há um processo rico em contradição se desenvolvendo. Foi escolhida a categoria lazer para consolidar as análises aproximadas à sustentabilidade nesse artigo, compreendendo esta como uma esfera da vida social imprescindível para a comunidade.

Em síntese, trata-se de reconhecer onde se situam o antigo, o novo, o diferente, uma vez que é a relação dialética desses três movimentos que mantém a reprodução do sistema. O novo aparece, 
muitas vezes, como tendência, uma novidade que contém diferentes tempos históricos, mas que, ao ser investigado, pode oferecer os elementos para uma análise que contribua para desvendar a essência da transformação da realidade.

\section{Discurso sustentável e remanejamento de população em risco}

Para embasar o processo de remanejamento para os conjuntos habitacionais do Projeto Taboquinha foi feito um levantamento socioeconômico prévio com a população a ser atendida que demonstrou que quanto aos responsáveis pelas famílias entrevistadas, $75 \%$ eram do sexo feminino, a maioria (65\%) com idade entre 18 e 45 anos, quase que a totalidade (93\%) natural do estado do Pará, cujo estado civil predominante era união estável com filhos, com escolaridade mais incidente no ensino fundamental incompleto. Normalmente estas pessoas têm entre duas a três pessoas sob sua responsabilidade financeira e educacional.

Quanto aos dependentes dos responsáveis pelas famílias, $72 \%$ eram estudantes, na maioria dos casos classificados no ensino fundamental incompleto. Tem renda mensal predominante na faixa de 1 a 2 salários-mínimos, normalmente garantidos por apenas um membro da família, no geral, advinda de atividades classificadas como autônomas. Era comum a dependência do igarapé para a garantia da renda familiar, pois era verificada a presença de muitos trabalhadores autônomos (pescadores) na comunidade. Detectou-se que em $11 \%$ das famílias entrevistadas possuíam uma pessoa portadora de necessidades especiais, porém apenas 1\% depende do uso de cadeira de rodas. Era observado o predomínio de uma população jovem, pois apenas 16\% possuíam mais de 65 anos. Quanto à moradia das famílias, prevaleciam os que moravam na área há mais de 5 anos, em condição de casa própria, construídas em madeira, dispondo de mais de 5 cômodos em estado de conservação predominantemente precário, no geral utilizado somente para fins de moradia (COHAB, 2007).

A partir destes dados, o direcionamento dado aos objetivos e principalmente às ações do PTTS foi delineado. Nota-se que a sustentabilidade aparece como elemento chave entre aspectos físicos e sociais no PTTS do Projeto Taboquinha, onde as estratégias pensadas pelos elaboradores visaram contribuir com ações destinadas à geração de ocupação e renda das famílias remanejadas para os conjuntos habitacionais construídos, conforme um dos objetivos propostos:

\begin{abstract}
"Realizar oficinas e/ou cursos de capacitação e qualificação profissional, proporcionandoacesso das famílias a atividades de ocupação e renda, que leve ao desenvolvimento econômico-financeiro que venha a contribuir para a sua fixação na área e a sustentabilidade das obras e serviços implantados" (COHAB, 2007, p.10).
\end{abstract}

A sustentabilidade é vista como objetivo a ser atingido para a manutenção e a fixação dos beneficiários aos conjuntos habitacionais, primeiramente, numa dimensão econômica, mas com sentido de tornar esses sujeitos plenamente adaptados ao novo ambiente de moradia, numa clara perspectiva social, onde a melhoria da qualidade de vida das famílias aparece como o objetivo final. Esta ideia tenta compatibilizar a necessidade de superação do quadro socioambiental problemático no espaço intraurbano com o desenvolvimento de uma política anticíclica de geração de emprego e renda, uma vez que também procura aproveitar a mão de obra local nas próprias obras executadas - ação contida na normativa de execução dos projetos - e, ao mesmo tempo, possibilitar alguma qualificação para a população beneficiária por meio dos cursos e oficinas ofertadas pelo PTTS.

"Na intenção de contribuirmos para o combate desta situação, apresentamos a presente proposta que está voltada à erradicação de palafitas na área do TABOQUINHA, onde de forma integrada e com a participação do beneficiário, serão desenvolvidas ações nas áreas, de saneamento, meio ambiente, habitação, educação, trabalho/renda, saúde, segurança, esporte, lazer e cultura. $[. . .]^{\prime \prime}$ 
"Pretendemos a partir da intervenção proposta, contribuir para a promoção de mudanças na realidade atual, onde as familias estão sobrevivendo em condições sub-humanas, localizadas em áreas insalubres e inadequadas para moradia" (COHAB, 2007, p. 7-8).

Nos termos do PTTS, a sustentabilidade reside em, além de "acabar com as palafitas na área do TABOQUINHA [...]", auxiliando na "[...] promoção de mudanças na realidade atual [...]", sem, no entanto, alterar o quadro de pobreza material estrutural das famílias, os inserindo naquilo que Lefebvre chama de espaço abstrato, numa tendência de continuação da atuação do Estado, via PAC, na reprodução de espaços para habitação contraditórios, como fotocópias de espaços-mercadorias, impondo controle social sobre as famílias a partir do remanejamento e da padronização monótona da tipologia que não tem relação com o entorno e com a própria cidade, no que Lefebvre (1973) chama de "periferias desurbanizadas, mas dependentes de cidade".

Nas entrevistas com os técnicos do Trabalho Social da COHAB/PA, ratificou-se o entendimento sobre a sustentabilidade como aspecto importante a ser considerado na execução das obras, mas sempre referente ao viés econômico, e, em primeiro lugar, à geração de ocupação e renda, ainda que de modo superficial, estando distantes quaisquer elementos ambientais. A adaptação das famílias tem primazia em relação às questões culturais ou relação dos sujeitos com o espaço construído:

"A perspectiva do trabalho técnico social é possibilitar ações que diminuam o impacto dessa transiç̧ão (da ocupação ao conjunto habitacional), principalmente no que diz respeito à melhoria da renda e condições de vida na nova residência. Muitas oficinas de artesanato, de panificação, de corte e costura, por exemplo, foram disponibilizadas para os beneficiários que buscaram nelas uma forma de melhorar sua renda, tudo isso ligado ao perfil socioeconômico que foi identificado [...] desse jeito, as familias conseguem uma forma de obtenção de sustento que antes não existia" (TS2).
As ações propostas pelo PTTS têm relevância dentro de um contexto de baixa qualificação percebida no perfil da população, embora não esteja conectada a ele claramente. O projeto não destina, por exemplo, qualquer atividade aos trabalhadores da pesca, considerados na análise do perfil socioeconômico como parcela significativa. Mesmo que tendo uma leitura sobre sustentabilidade mais aproximada ao viés socioeconômico, o Projeto não consegue fazer uma interpretação das necessidades da comunidade, neste aspecto. Desprezou-se, assim, a vivência da população e uma importante expressão relacionada a sua base material.

Nas entrevistas com os técnicos responsáveis pela elaboração e execução dos projetos físicos, destacou-se também o caráter inédito que trouxe o PAC em relação à destinação de aporte financeiro exclusivamente direcionado ao trabalho técnico social de forma a complementar à mudança das famílias para os conjuntos, o que também exprime a sustentabilidade de forma econômica. Conforme o Técnico TF1 destaca:

"A gente não pode falar mal do PAC. Pela primeira vez na história houve recurso exclusivo para um trabalho social, um trabalho que vem somar ao que o projeto físico elabora, de certo modo. No caso do Taboquinha, a mudança foi muito grande porque os locais onde as pessoas moravam era precário e a mudança para os blocos foi um grande avanço para as famililas, embora saibamos que ainda há muito o que melhorar nessa dinâmica tanto em relação ao projeto das unidades, quanto nas condições de vida das familias. Essas familias moravam em cima da água, na área do antigo lgararpé Cubatão. [...] A questão da água, da acessibilidade, da destinação do lixo foi resolvida. 0 PAC tem uma das melhores filosofias ambientais entre os programas já elaborados que eu conheço desde que eu entrei na COHAB, na década de 1970".

“O PAC foi um laboratório incrivel para nós [...] a amarração que as normativas têm na questão ambiental é muito importante" (TF2).

"O desafio era grande. 0 projeto continha uma praça para cada conjunto, mas como os recursos foram ficando sem 
atualização desde a aprovação, creio que apenas uma delas ficou como inicialmente deveria" (TF1).

Embora os elogios à estrutura do Programa sejam relevantes, sinalizando o início de uma nova abordagem frente aos processos de remanejamento e reassentamento urbanos, destinando recursos ao trabalho técnico social, há lacunas bastante significativas ainda não preenchidas na execução, como negação das vivências da população atendida, o tipo de espaço produzido, ausência de espaços de lazer, ausência de espaços de consumo, distanciamento em relação às práticas cotidianas anteriores, como fica evidente nas respostas dos beneficiários B8 e B11, respectivamente:

"Sobre o lazer acho até que piorou porque antes lá no Cubatão (ocupação) as crianças brincavam no campo de futebol que tinha lá. Aqui não tem nada. Disseram que ia ser construída uma praça, mas a única que tem nem é do Conjunto... As crianças brincam aqui fora, mas não acho seguro".

"Aqui não é ruim porque a gente não está mais em cima da água em casa de madeira, mas ficou tudo diferente. Nossos vizinhos foram pro Mestre Cardoso e a gente veio pra cá... A gente tinha uma vida lá e outra aqui. Em algumas coisas melhorou. Em outras não, mas a gente acaba dando um jeito. A gente ficou longe e acabou conhecendo outras pessoas. A verdade é que a gente se adapta em qualquer lugar se for preciso, né?"

Para Lefebvre (1973), o espaço tem um aspecto perceptível que pode ser apreendido por meio dos sentidos. Essa percepção constitui um componente integral de toda prática social. Ela compreende tudo que se apresenta aos sentidos; não somente a visão, mas a audição, o olfato, o tato e o paladar. Esse aspecto sensualmente perceptivo do espaço relaciona-se diretamente com a materialidade dos "elementos" que constituem o "espaço". No caso das famílias remanejadas os juízos de valor descritos são interpretações do espaço percebido que contém suas valorações sobre o novo espaço em oposição ao antigo, como "melhor" ou "pior", isto é, uma contraposição que define suas representações do espaço, nas passagens acima, relativizando os problemas ainda presentes em função do acesso à casa própria.

Nas entrevistas com os beneficiários é perceptível que estes veem a mudança para os conjuntos como positiva, sendo as unidades vistas como adequadas em comparação à ocupação onde residiam. A observação negativa mais apontada é o valor das contas de energia elétrica, como frisou B4. B6 destacou a importância das ações do trabalho técnico social:

"O conjunto é melhor que o lugar onde a gente morava, mas o que ficou difícil aqui é a conta da CELPA (concessionária de energia). Ficou muito difícil pagar a conta porque lá a gente pagava taxa e aqui o valor é alto. É um absurdo! [...] A gente sabe que vai sair da palafita e ir pra um lugar melhor, mas pra mim, as coisas pioraram por causa do meu trabalho porque sou costureira e a energia elétrica é importante".

O espaço não pode ser percebido enquanto tal sem ter sido concebido previamente em pensamento. A junção de elementos para formar um "todo" que é então considerado ou designado como espaço presume um ato de pensamento (LEFEBVRE, 1973). O espaço concebido, nesse caso, não consegue atender às necessidades dos beneficiários, principalmente no que diz respeito ao trabalho, o que vai de encontro às estratégias pensadas pelo PTTS para qualificar pessoas da comunidade, sem falar nas questões estruturais citadas em relação ao lazer, espaços de uso comum, às unidades habitacionais e ao acesso a serviços básicos.

B8 destacou que há consideração por parte dos beneficiários da importância da mudança de sua família para unidades habitacional, em relação à qualidade do ambiente construído, embora considere ainda distante do desejável como um bom espaço para viver, pois "[...] ainda tem muito problema. Problema com água, o lixo demora pra ser recolhido... Mas a gente não tem que reclamar, 
não. Hoje a gente vive num lugar nosso".

Outro aspecto importante para a análise é a associação entre a mudança de residência e o valor de troca que fica estabelecido após esta mudança, como fica claro na resposta de B11: "Muita gente já saiu daqui... Vendeu e foi pra outro lugar. Quando tinha fiscalização da COHAB não tinha tanta gente vendendo, alugando... Tem gente que ganha dinheiro".

Assim, as intervenções habitacionais do Projeto Taboquinha tendem a negar as vivências dos beneficiários, sobretudo, em função do tipo de espaço de moradia, tipo de espaço de lazer, o que reforça o entendimento destes espaços como abstratos que se contrapõem a espaços sociais, mais orgânicos no sentido das relações sociais neles estabelecidas. São espaços homogêneos, fragmentados, hierárquicos, que valorizam o quantitativo, o regulado, sem valor de uso, isto é, são espaços-produto.

O espaço vivido, a terceira dimensão da produção do espaço é a experiência vivida do espaço, resiste como resíduo nesse contexto. Essa dimensão significa o mundo assim como ele é experimentado pelos seres humanos na prática de sua vida cotidiana. No nosso caso, reside na experiência dos beneficiários, não mensurada pelo PTTS ou pelo projeto construtivo, mas que resiste quando B9 diz que "[...] fazemos duas festas por ano aqui que a gente já fazia no Cubatão: no Dia das Crianças e no Natal, quando a gente se reúne e é bem legal...". Um movimento que parte da tradição e da relação afetuosa entre os sujeitos que transcende a materialidade e congrega um sentido de comunhão. Tal como Lefebvre destaca o vivido: como a experiência prática que não se deixa exaurir. Sempre permanecendo como um excedente, um remanescente, o indizível, o que não é passível de análise, apesar de ser o mais valioso resíduo.

\section{Conclusões}

Não é possível pensar nos conjuntos habitacionais periféricos para remanejamento de famílias em situação de vulnerabilidade descolados da realidade e do sistema econômico que o produz e das implicações que essa produção traz consigo. Considerar a estrutura socioeconômica e as carências não apenas advindas dela é indispensável para entender como esses espaços habitacionais para os mais pobres são produzidos, como é o caso em estudo.

A sustentabilidade descrita no PTTS do Projeto Taboquinha é discursiva e deslocada da realidade atual das famílias na efetivação do projeto e no remanejamento, pois as ações se baseiam exclusivamente no aspecto econômico, mas com nenhum nexo com a vida material dos beneficiários. Embora o acesso à casa própria seja valorizado e as condições de habitação sejam melhores em relação à precariedade da ocupação irregular e vulnerável habitada anteriormente, na categoria lazer há uma lacuna não preenchida que denota, além da desconsideração da necessidade de espaços e relações, a reprodução de uma lógica pautada na homogeneização, na monotonia e sem conexão com as vivências da população atendida.

O Programa impõe tipo de espaço de moradia, tipo de espaço de lazer, tipo de consumo. São espaços abstratos que se contrapõem a espaços sociais (do comércio, das feiras, dos campos de futebol, dos ambulantes). Cria-se um espaço que, entre outros problemas, valoriza o quantitativo, o regulado, sem valor de uso, o espaço-produto, como fotocópia de um espaço-mercadoria.

Obviamente, os limites do trabalho ora exposto são estabelecidos pela análise de apenas uma das três categorias destacadas por Lefebvre, como essenciais para a consideração do cotidiano, sendo este artigo ainda uma aproximação superficial com carências de aprofundamento nas outras e na gama de encadeamentos que o tema suscita.

\section{Referências bibliográficas}

ABIKO, A.; COELHO, L. O. Urbanização de Favelas:

procedimentos de gestão. Porto Alegre: ANTAC, 2009.

ACSELRAD, $H$. Discursos da Sustentabilidade Urbana. Revista Brasileira de Estudos Urbanos e

Regionais, número 1, 1999. 
ACSELRAD, H. Desregulamentação, Contradições Espaciais e Sustentabilidade Urbana. Anais do XI Encontro Nacional de Pesquisa em PósGraduação e Pesquisa em Planejamento Urbano e Regional, ANPUR. Salvador: UFBA, 2005.

ACSELRAD, H. A Duração das Cidades: sustentabilidade e Risco nas Políticas Urbanas. 2a ed. Henri Acselrad (Org.). Rio de Janeiro: Editora DP\&A/ Lamparina, 2009.

BRASIL. Estatuto das Cidades. Lei Federal n. 10.257/2001. Congresso Nacional, 2001.

BRASIL. Ministério das Cidades. Experiências em Habitação de Interesse Social no Brasil. ARRUDA, A.M.V; CUNHA, E.M.P; MEDEIROS, Y. (Org.). Brasília: Secretaria Nacional de Habitação, 2008.

BRASIL. Ministério das Cidades. Programa de Aceleração do Crescimento. Disponível em http:// www.pac.gov.br/ Acesso em 25 de novembro de 2018.

BRASIL. Ministério das Cidades. Relatório de Gestão do FNHIS. Secretaria Nacional de Habitação, 2010.

CARDOSO, A. C. Uma discussão sobre Políticas Públicas Relacionadas à Habitação e à Cidade e sua Relação com os Programas Implantados Durante a Segunda Gestão do Governo Lula. Natal: Departamento de Políticas Públicas da UFRN, 2009

CARDOSO, A. C.; VENTURA NETO, R. A Evolução Urbana de Belém: trajetória de Ambiguidades e Conflitos Socioambientais. Cadernos Metrópole. São Paulo, v. 15, n. 29, p. 55-75, jan/jun 2013.

CASTRO, M. O. Os programas Habitacionais de Interesse Social e sua Atuação na Região Metropolitana de Belém: a Espacialização das Ações na Contramão do Direito à Cidade. Dissertação (Mestrado). Universidade Federal do Pará, Instituto de Filosofia e Ciências Humanas, Programa de Pós-Graduação em Geografia, Belém, 2013.
CORREAA, R. L. Trajetórias geográficas. Rio de Janeiro: Bertrand Brasil, 1997.

COSTA, H. S. M. Desenvolvimento Urbano Sustentável: uma contradição de termos? Revista Brasileira de Estudos Urbanos e Regionais, n. 2, 1999.

HARVEY, D. A Produção Capitalista do Espaço. São Paulo, Annablume, 1981.

HARVEY, D. A Justiça Social e a Cidade. São Paulo: Hucitec, 1982.

IBGE. Instituto Brasileiro de Geografia e Estatística. Aglomerados Subnormais, Informações Territoriais. Primeiros resultados. Rio de Janeiro, 2010.

IPEA/IDESP. Relatório de Pesquisa 1.2: Análise Comparativa das Funções Públicas de Interesse Comum. Região Metropolitana de Belém. Brasília: 2013.

JACOBI, P. Impactos socioambientais urbanos - do risco à busca da sustentabilidade. In: MENDONÇA, F. (org.) Impactos Socioambientais Urbanos. Curitiba: Editora UFPR, 2004. 330 p.

JAPIASSU, H. Interdisciplinaridade e Patologia do saber. Rio de Janeiro: Imago, 1976.

CEF - Caixa Econômica Federal. Selo Casa Azul. Boas práticas para habitação mais sustentável. São Paulo: Páginas \& Letras - Editora e Gráfica, 2010

LEÃO, M. S.; LIMA, J. J. F. Reassentamento involuntário em projetos de saneamento em Belém do Pará. Revista e-metrópolis. Número 25, ano 7, 2017.

LEFEBVRE, H. A Reprodução das Relações de Produção. Tradução: Antonio Ribeiro e M. do Amaral. Porto: Publicações Escorpião - Cadernos O Homem e a Sociedade, 1973.

LEFEBVRE, H. Critique de la Vie Quotidienne I: Introduction. Paris: Arche, 1978. 
LEFEBVRE, H. The Production of Space. Tradução Roberta Tavares. Blackwell Publishing (EUA), 1991.

LEFEBVRE, H. O direito à cidade. São Paulo: Centauro Editora, 2004.

LEFEBVRE, H. Ecologia, Capital e Cultura: a territorialização da racionalidade ambiental. Petrópolis: Editora Vozes, 2009.

\section{LEITÃO, K. O. A Dimensão Territorial do Programa} de Aceleração do Crescimento: o estudo sobre o PAC no estado do Pará e o lugar que ele reserva à Amazônia no desenvolvimento do País. Tese (Doutorado). Programa de Pós-Graduação em Arquitetura e Urbanismo da Universidade de São Paulo, 2009.

LIMA, J. J. F.; LEÃO, M. S.; LIMA, A. P. Limitações na gestão do PAC urbanização: o caso do Projeto PAC Taboquinha, Belém do Pará. Anais do XVII Encontro Nacional ANPUR. São Paulo, 2017.

LIMA, J. J. F. et al. A questão habitacional na Região Metropolitana de Belém. In: CARDOSO, A. L. (org.). Habitação Social nas Metrópoles Brasileiras: uma avaliação das políticas habitacionais em Belém, Belo Horizonte, Porto Alegre, Recife, Rio de Janeiro e São Paulo no final do século XX. Porto Alegre: ANTAC, 2007 (Coleção Habitare).

MARICATO, E. Metrópole na periferia do capitalismo: ilegalidade, desigualdade e violência. São Paulo: Hucitec, 2005.

MARICATO, E. Metrópole, Legislação e Desigualdade. Revista Estudos Avançados, 2003. Disponível em: <http://www.scielo.br/pdf/ea/v17n48/v17n48a13. pdf >. Acesso em: 15 nov. 2018.

MARICATO, E. As Tragédias Urbanas: desconhecimento, ignorância ou cinismo? São Paulo: GEOUSP, 2009.

MARICATO, E. O impasse da Política Urbana no Brasil. São Paulo: Editora Vozes, 2011.
MCIDADES. Ações Integradas de Urbanização de Assentamentos Precários - Edição Bilíngue. Brasília/São Paulo: Ministério das Cidades/Aliança de Cidades, 1a edição/2010.

MPOG. Ministério do Planejamento, Orçamento e Gestão. 4 ${ }^{\circ}$ Balanço do PAC (Pará) 2015-2018. Brasília: MPOG, 2016.

MPOG. Ministério do Planejamento, Orçamento

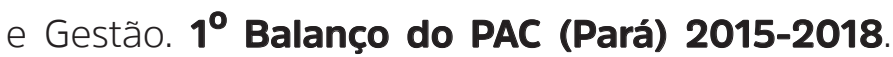
Brasília: MPOG, 2015.

MPOG. Ministério do Planejamento, Orçamento e Gestão. $1^{0}$ Balanço do PAC2 (2011-2014). Brasília: MPOG, 2014.

MPOG. Ministério do Planejamento, Orçamento e Gestão. 11 $^{\circ}$ Balanço do PAC2. Brasília: MPOG, 2014.

PARÁ. Companhia Executiva de Habitação do Pará. Balanço das Ações de 2012. Slides Ppt. Belém: COHAB, 2011.

PARÁ. Companhia Executiva de Habitação do Pará. Projeto de Trabalho Técnico Social do Projeto PAC Taboquinha. Belém: COHAB, 2007. Inédito.

ROLNIK, R. (Org.) Como Produzir Moradia bem Localizada com Recursos do Programa Minha Casa Minha Vida? Implementando os instrumentos do Estatuto da Cidade. Brasília: Ministério das Cidades, 2010.

ROLNIK, R. Pactuar o Território: desafio para a gestão de nossas cidades. Publicado em 01/09/2008. Disponível em <http://raquelrolnik. wordpress.com/2008/09/01/desafios-da-gestaourbana/>. Acesso em: 09 de agosto de 2018.

ROLNIK, R.; CYMBALISTA, R.; NAKANO, K. Solo urbano e habitação de interesse social: a questão fundiária na política habitacional e urbana do país. Revista de Direito da ADVOCEF, v. 1, p. 123-158, 2011.

SOUZA, M. J. L. Desenvolvimento urbano: a 
problemática renovação de um "conceito" -problema. Revista Território, ano 3, número 5, 1998.

SOUZA, M. J. L. Mudar a cidade: uma introdução crítica ao planejamento e à gestão urbanos. $4^{a}$ ed. Rio de Janeiro: Editora Bertrand Brasil, 2002.

TRINDADE JR., S.-C. C. A Cidade Dispersa: os novos espaços de assentamentos em Belém e a reestruturação metropolitana. 1998. Tese (Doutorado) - Faculdade de Filosofia, Letras e Ciências Humanas, Universidade de São Paulo, São Paulo, 1998.

TRINDADE JR., S.-C. C. Formação metropolitana de Belém (1960-1997). Belém: Paka-Tatu, 2016.

UN-HABITAT. Planning sustainable cities. Global report on human settlements 2009. London, UK: United Nations Human Settlements Programme (UN-HABITAT), 2009.

UN-HABITAT. Forced Eviction: Global crisis, Global solutions. A Review of the status of Forced Evictions Globally through the Work of the Advisory Group on Forced Evictions, Un-Habitat and Other International Actors. United Nations Human Settlements Programme (UN-HABITAT), Nairobi, 2011.

UN-HABITAT. Sustainable housing for sustainable cities a policy framework for developing countries. Nairobi, Kenya: United Nations Human Settlements Programme (UN-HABITAT), 2012.

UNCSD. Rio+20 - United Nations Conference on Sustainable Development. Disponível em: <www. uncsd2012.org >Acesso em: maio 2018.

VILLAÇA, F. Espaço intra-urbano no Brasil. São Paulo: Studio Nobel: FAPESP: Lincoln Institute, 2001. 